Report of Investigation 2018-5 v. 2

\title{
UPDATED TSUNAMI INUNDATION MAPS FOR HOMER AND SELDOVIA, ALASKA
}

E.N. Suleimani, D.J. Nicolsky, and J.B. Salisbury

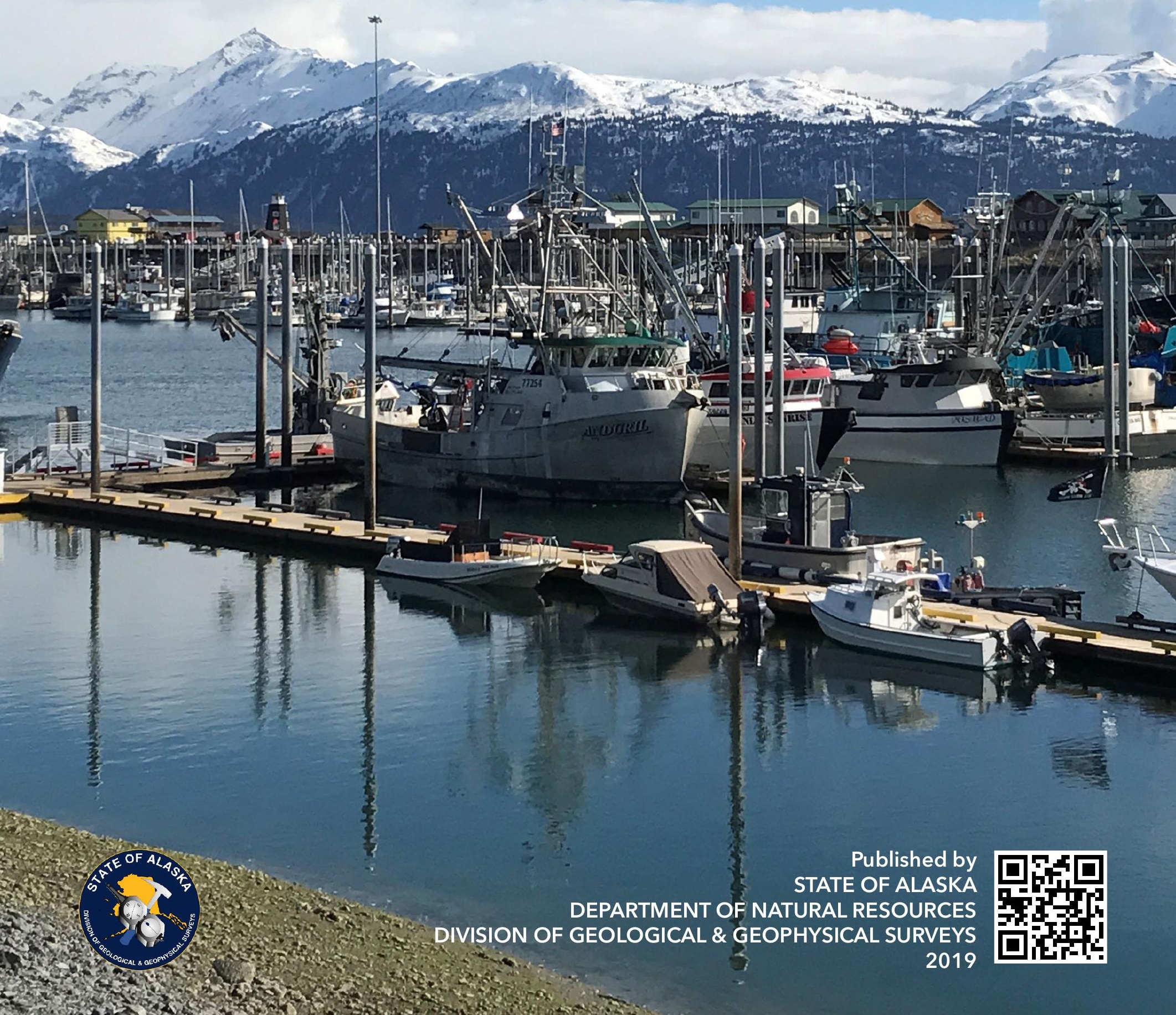


Cover. View from the Homer Harbormaster Office looking southeast across the Port and Harbor. 


\section{UPDATED TSUNAMI INUNDATION MAPS FOR HOMER AND SELDOVIA, ALASKA}

E.N. Suleimani, D.J. Nicolsky, and J.B. Salisbury

Report of Investigation $2018-5$ v. 2

State of Alaska

Department of Natural Resources

Division of Geological \& Geophysical Surveys 
STATE OF ALASKA

Michael J. Dunleavy, Governor

DEPARTMENT OF NATURAL RESOURCES

Corri A. Feige, Commissioner

DIVISION OF GEOLOGICAL \& GEOPHYSICAL SURVEYS

Steve Masterman, State Geologist and Director

Publications produced by the Division of Geological \& Geophysical Surveys (DGGS) are available for free download from the DGGS website (dggs.alaska.gov). Publications on hard-copy or digital media can be examined or purchased in the Fairbanks office:

Alaska Division of Geological \& Geophysical Surveys 3354 College Rd., Fairbanks, Alaska 99709-3707

Phone: (907) 451-5010 Fax (907) 451-5050

dggspubs@alaska.gov|dggs.alaska.gov

DGGS publications are also available at:

Alaska State Library,

Historical Collections \& Talking Book Center

395 Whittier Street

Juneau, Alaska 99811

Alaska Resource Library and Information Services (ARLIS)

3150 C Street, Suite 100

Anchorage, Alaska 99503

Suggested citation:

Suleimani, E.N., Nicolsky, D.J., and Salisbury, J.B., 2019, Updated tsunami inundation maps for Homer and Seldovia, Alaska: Alaska Division of Geological \& Geophysical Surveys Report of Investigation 2018-5 v. 2, 97 p., 11 sheets. doi.org/10.14509/30095

This report was originally released October 2018 and updated August 2019.
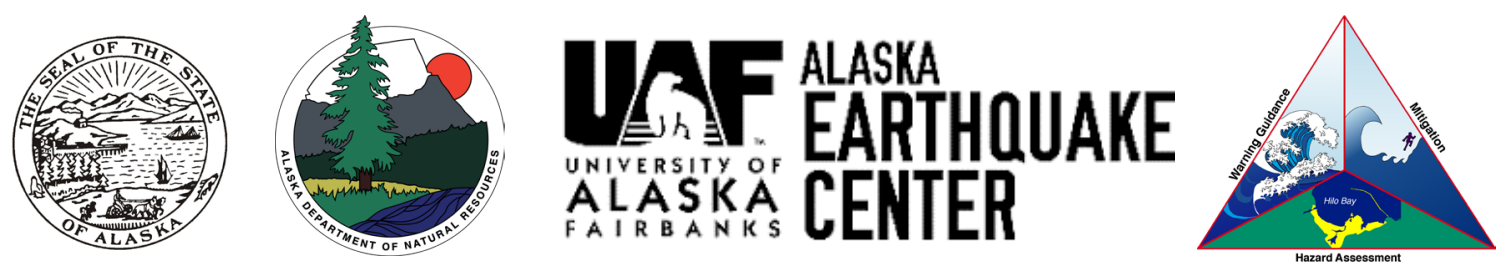
This page intentionally left blank. 


\section{Contents}

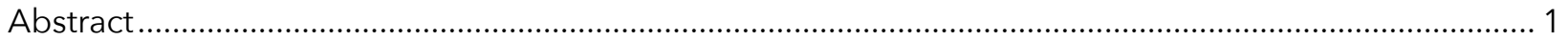

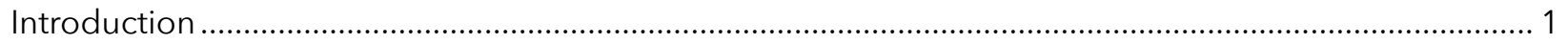

Project Background: Regional and Geological Context................................................................. 3

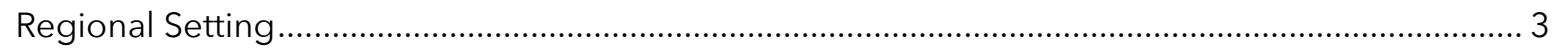

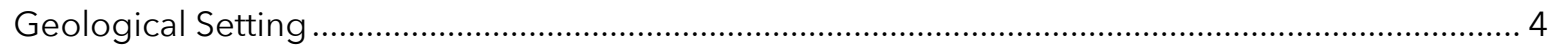

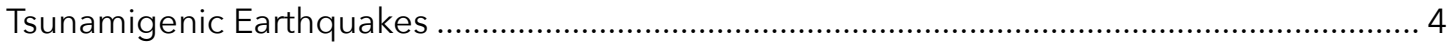

The 1964 Earthquake and Tsunami................................................................................... 6

Geodetic Studies .................................................................................................. 8

Paleoseismology .................................................................................................... 8

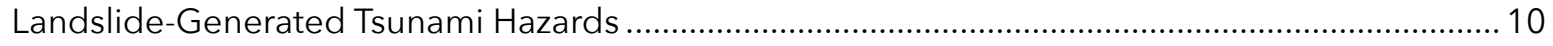

Volcano-Generated Tsunami Hazards .................................................................................... 11

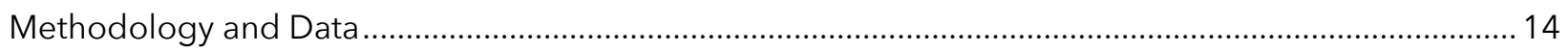

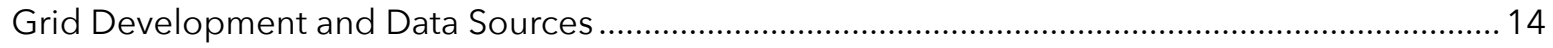

Numerical Model of Tsunami Propagation and Runup ........................................................... 15

Numerical Model of Landslide-Generated Tsunamis....................................................................16

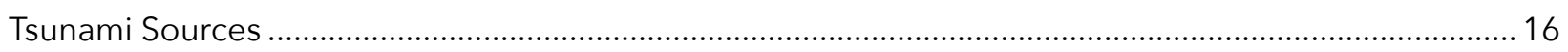

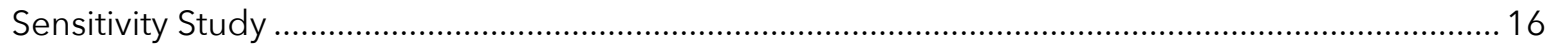

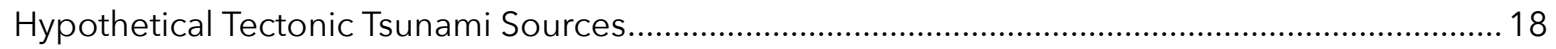

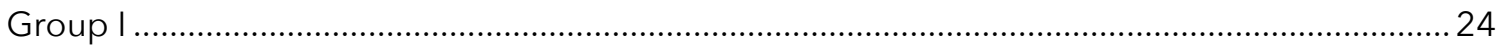

Scenario 1. Repeat of the $M_{w} 9.2$ Great Alaska Earthquake.................................................2 24

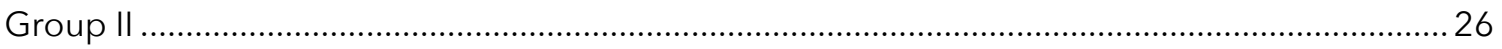

Scenario 2. $M_{W} 9.2$ earthquake in the KI-KP region: Predominantly shallow slip with maximum slip at a depth of $0-10 \mathrm{~km}(0-6.2 \mathrm{mi})$.....................................................2

Scenario 3. $M_{W} 9.3$ earthquake in the KI-KP region: Predominantly shallow slip

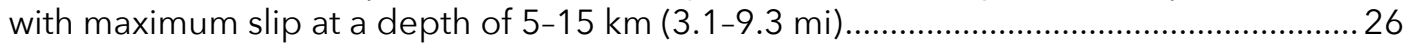

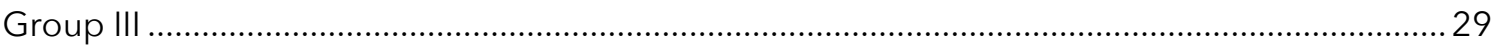

Scenario 4. $\mathrm{M}_{\mathrm{W}} 9.25$ earthquake in the KI-KP region with $50 \mathrm{~m}$ ( $164 \mathrm{ft}$ ) of maximum slip in the shallow part of the rupture and uniform along-strike slip

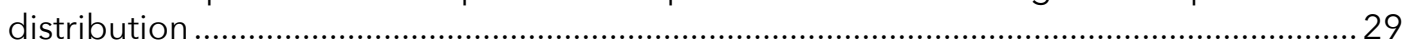

Scenario 5. $M_{W} 9.3$ earthquake in the KI-KP region: Predominantly shallow slip with maximum slip at a depth of 5-15 km (3.1-9.3 mi) and uniform along-strike slip distribution.

Scenario 6. $M_{W} 9.3$ earthquake in the KI-KP region: maximum slip at a depth of 15-35 km (9.3-21.7 mi) and uniform along-strike slip distribution

Scenario 7. $\mathrm{M}_{\mathrm{W}} 9.2$ earthquake in the KI-KP region with $35 \mathrm{~m}$ ( $114.8 \mathrm{ft}$ ) of maximum slip (for almost the entire rupture patch) and uniform along-strike

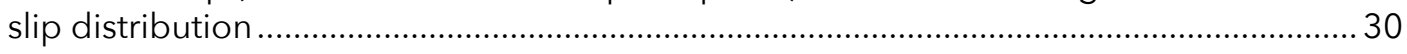

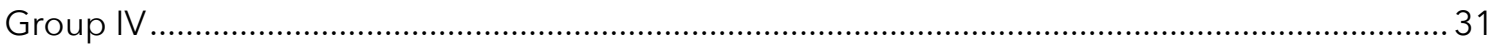

Scenario 8. $M_{W} 9.0$ earthquake according to the SAFRR project.............................................31

Scenario 9. $M_{W} 9.1$ earthquake in the Cascadia subduction zone along the British Columbia, Washington, Oregon, and northern California shores........................................ 31

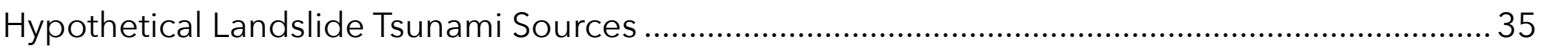

Hypothetical Landslide Scenarios for the City of Homer: ............................................................. 37

Scenario 10. An underwater slide offshore of the Cook Inlet side of Homer spit...................37

Scenario 11. An underwater slide offshore at the tip of Homer Spit.......................................37

Scenario 12. An underwater slide offshore of the Kachemak Bay side of Homer Spit ..........38

Scenario 13. An underwater slide at the mouth of the Wosnesenski River .............................38

Scenario 14. An underwater slide at the mouth of the Grewingk Creek..................................38 


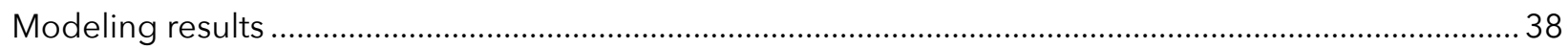

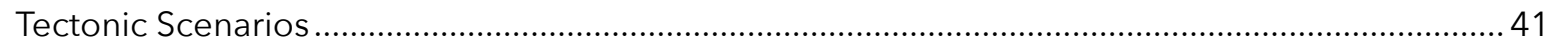

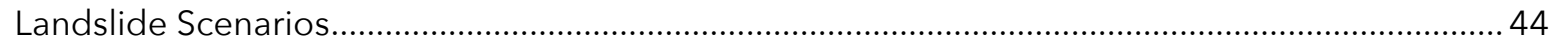

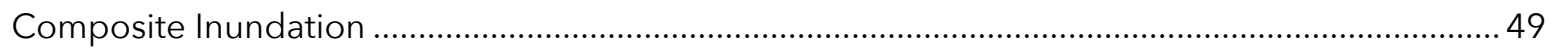

Time Series and Other Numerical Results ............................................................................. 52

Sources of Errors and Uncertainties ......................................................................................... 54

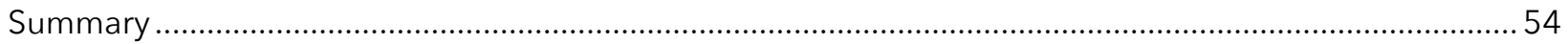

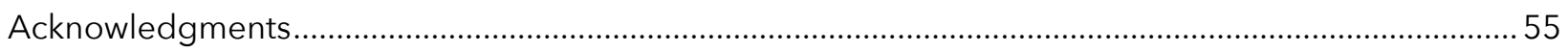

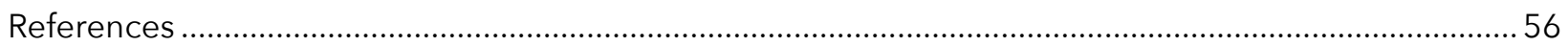

\section{Figures}

Figure 1. Map of south-central Alaska, showing the location of Kodiak Island, Kenai

Peninsula, and the rupture zones of the 1788, 1938, and 1964 Aleutian megathrust earthquakes...... 2

Figure 2. Map of lower Cook Inlet and Kachemak Bay.......................................................................... 3

Figure 3. Cartoon illustration of a megathrust earthquake cycle where the overriding plate

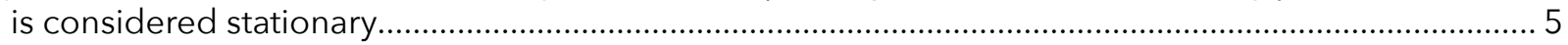

Figure 4. Schematic three-dimensional representation of asperities on a subduction zone

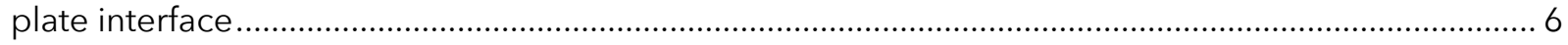

Figure 5. Measured coseismic deformations of the 1964 earthquake from Plafker (1969) and two major asperities of the 1964 rupture zone .......................................................................... 7

Figure 6. Sketch of Homer Spit showing locations of slope failures that occurred during

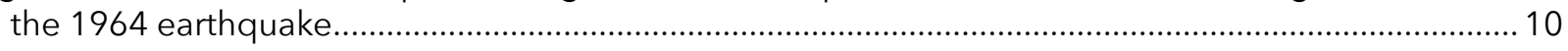

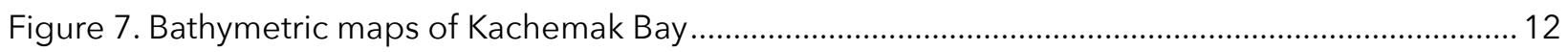

Figure 8. Potential source locations of underwater slides in the vicinity of Homer................................. 14

Figure 9. Nesting of the levels 0-4 bathymetry/topography grids for numerical modeling of tsunami propagation and runup in the Kachemak Bay area, and discretization of the plate interface used to compute the coseismic vertical displacements

Figure 10. Slip distributions along the plate interface and computed vertical coseismic deformations for sensitivity study cases $A-D$ modeling $M_{W} 8.0$ ruptures in the area

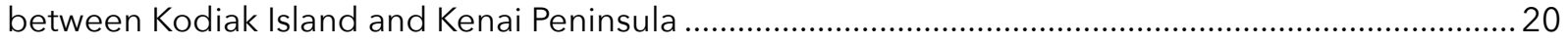

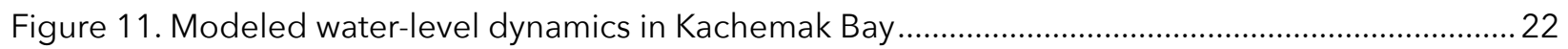

Figure 12. Mosaic of the discretized plate interface used for construction of hypothetical ruptures ..... 24

Figure 13. Computed vertical ground-surface deformations for scenario 1 .............................................25

Figure 14. Slip distributions along the plate interface and computed vertical coseismic deformations for scenario 2 .

Figure 15. Slip distributions along the plate interface and computed vertical coseismic deformations for scenario 3 .

Figure 16. Slip distributions along the plate interface and computed vertical coseismic deformations for scenario 4 ......

Figure 17. Slip distributions along the plate interface and computed vertical coseismic deformations for scenario 5 .

Figure 18. Slip distributions along the plate interface and computed vertical coseismic deformations for scenario 6 .

Figure 19. Slip distributions along the plate interface and computed vertical coseismic

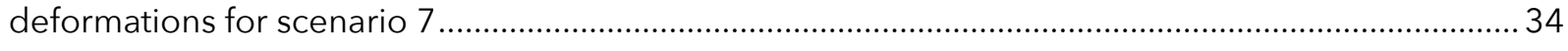

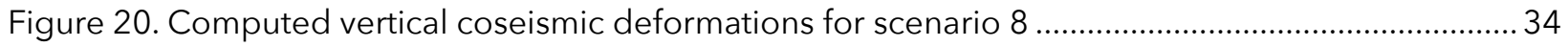

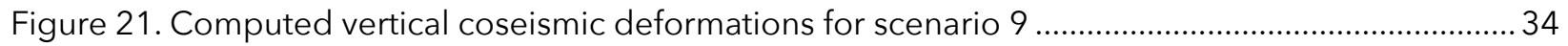

Figure 22. Locations and initial landslide thicknesses for hypothetical landslide scenarios .................... 39 
Figure 23. Modeled potential inundation for the town of Homer by tectonic tsunami waves for selected scenarios.

Figure 24. Modeled potential inundation for Homer Spit by tectonic tsunami waves for selected scenarios.

Figure 25. Modeled potential inundation for Seldovia by tectonic tsunami waves for selected scenarios.

Figure 26. Modeled maximum composite flow depth over dry land for all tectonic scenarios for the town of Homer

Figure 27. Modeled maximum composite flow depth over dry land for all tectonic scenarios for Homer Spit.

Figure 28. Modeled maximum composite flow depth over dry land for all tectonic scenarios for Seldovia.

Figure 29. Comparison of scenarios 10 and 11 NHWAVE- and FUNWAVE-computed water-level dynamics at three stations.

Figure 30. Results of the enhanced scenario 10 for increased volume of the landslide

Figure 31. Maximum wave height above the MHHW level in Kachemak Bay for landslide scenarios .... 50

Figure 32. Maximum composite flow depth over dry land and maximum composite extent of inundation for landslide scenarios in Homer

\section{Tables}

Table 1. Tsunami effects for Homer and Seldovia.

Table 2. Nested grids used to compute propagation of tsunami waves generated in the Pacific Ocean to Homer and Seldovia.

Table 3. Hypothetical tectonic scenarios used to model tsunami runup in Homer and Seldovia.

Table 4. Fault parameters for the splay fault in scenario 6D.....

Table 5. Hypothetical landslide scenarios used to model potential extent of inundation by landslide-generated tsunamis 


\section{Appendix}

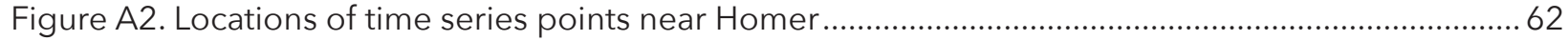

Figure A1. Locations of time series points in Cook Inlet and Kachemak Bay ........................................... 62

Table A1. Maximum water levels and water velocities for tectonic scenarios at time series points near Homer and Homer Spit....

Table A2. Maximum water levels and water velocities for landslide scenarios at time series points near Homer and Homer Spit.

Figure A3. Time series of water level and velocity for tectonic scenarios 1-3 at selected locations shown in figures $\mathrm{A} 1$ and $\mathrm{A} 2$

Figure A4. Time series of water level and velocity for tectonic scenarios 4-7 at selected locations shown in figures $\mathrm{A} 1$ and $\mathrm{A} 2$

Figure A5. Time series of water level and velocity for tectonic scenarios 8-9 at selected locations shown in figures $\mathrm{A} 1$ and $\mathrm{A} 2$.

Figure A6. Time series of the water level and velocity for landslide scenarios 10-14 at selected locations shown in figures $\mathrm{A} 1$ and $\mathrm{A} 2$.

Figure B1. Locations of time series points in Cook Inlet and Seldovia Bay

Figure B2. Locations of time series points near Seldovia.

Table B1. Maximum water levels and water velocities for tectonic scenarios at time series points near Seldovia.....

Figure B3. Time series of water level and velocity for tectonic scenarios 1-3 at selected locations shown in figure B1.

Figure B4. Time series of water level and velocity for tectonic scenarios 4-7 at selected locations shown in figure B1.

Figure B5. Time series of water level and velocity for tectonic scenarios 8 and 9 at locations shown in figure B1.....

Figure C1. Tsunami hazard boundary in Kachemak Selo

Figure C2. Time series of water level for the worst-case tectonic scenario at the location shown in figure $\mathrm{C} 1$

\section{Map Sheets}

Sheet 1. Maximum estimated tsunami inundation, Homer, Alaska

Sheet 2. Maximum estimated tsunami inundation, downtown Homer, Alaska

Sheet 3. Maximum estimated tsunami inundation, Homer Spit, Alaska

Sheet 4. Maximum estimated tsunami inundation, Seldovia, Alaska

Sheet 5. Maximum estimated tsunami inundation, Seldovia City, Alaska

Sheet 6. Maximum estimated tsunami inundation, Seldovia Bay, Alaska

Sheet 7. Maximum estimated tsunami inundation, Point Naskowhak, Alaska

Sheet 8. Maximum estimated tsunami inundation, Seldovia Village (West), Alaska

Sheet 9. Maximum estimated tsunami inundation, Seldovia Village (East), Alaska

Sheet 10. Maximum estimated tsunami inundation, Kasitsna Bay, Alaska

Sheet 11. Maximum estimated tsunami inundation, Jakolof Bay, Alaska 
This page intentionally left blank. 


\title{
UPDATED TSUNAMI INUNDATION MAPS FOR HOMER AND SELDOVIA, ALASKA
}

\author{
E.N. Suleimani ${ }^{1}$, D.J. Nicolsky ${ }^{1}$, and J.B. Salisbury ${ }^{2}$
}

\begin{abstract}
We re-evaluate the potential tsunami hazard for the communities of Homer and Seldovia by numerically modeling the extent of inundation from tsunami waves generated by earthquakes and submarine landslides. Hypothetical worst-case scenarios are defined by analyzing the tsunami dynamics related to various plausible earthquake slip distributions along the Alaska-Aleutian megathrust. Potential tsunami sources include megathrust earthquakes in the Prince William Sound, Kenai Peninsula, and Kodiak Island regions. We consider scenarios similar to that of the 2011 Tohoku earthquake in Japan, with maximum slip located on a shallow portion of the plate interface close to the seafloor trench. We also consider local underwater slope failure scenarios for Kachemak Bay. The maximum predicted wave height from a tectonic tsunami is 10-12 m (33-40 ft) in Homer and 10-11 m (33-36 ft) in Seldovia,

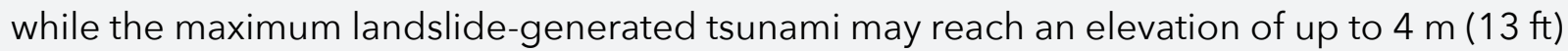
on Homer Spit. In addition to Homer and Seldovia, we assessed the tsunami hazard for three small communities in Kachemak Bay: Seldovia Village, Jakolof Bay, and Kachemak Selo. Results presented here are intended to provide guidance to local emergency management agencies for tsunami inundation assessment, evacuation planning, and public education to mitigate future tsunami hazards. This report updates the previous assessment of tsunami hazard for Homer and Seldovia published in 2005.
\end{abstract}

\section{INTRODUCTION}

Subduction of the Pacific plate under the North American plate has resulted in numerous great earthquakes and is the source of locally generated tsunamis in Alaska (Dunbar and Weaver, 2008). Several historic earthquakes along the Alaska-Aleutian subduction zone (fig. 1) have generated tsunamis resulting in widespread damage and loss of life in exposed coastal communities in Alaska and throughout the Pacific (Lander, 1996). However, tsunamis originating in the vicinity of the Alaska Peninsula, Aleutian Islands, and Gulf of Alaska are considered near-field hazards for Alaska, and could reach Alaska's coastal communities within minutes of an earthquake. Reducing property damage and loss of life is highly dependent on community preparedness. Thus, estimating the potential flooding of the coastal zone in the event of a local or distant tsunami is an essential component of the preparedness process.

On March 27, 1964, the largest earthquake ever recorded in North America struck south-central Alaska. This $\mathrm{M}_{\mathrm{W}} 9.2$ megathrust earthquake (fig. 1) generated the most destructive tsunami in Alaska history and, farther south, impacted the west coast of the United States and Canada (Plafker and others, 1969; Kanamori, 1970; Johnson and others, 1996; Lander, 1996). In addition to the major tectonic tsunami that was generated by ocean-floor displacement between the trench and coastline, more than 20 local tsunamis were generated by submarine and subaerial landslides in coastal Alaska during the 1964 earthquake (Lander, 1996). They arrived almost immediately

\footnotetext{
${ }^{1}$ Alaska Earthquake Center, Geophysical Institute, University of Alaska, P.O. Box 757320, Fairbanks, Alaska $99775-$ 7320; ensuleimani@alaska.edu

${ }^{2}$ Alaska Division of Geological \& Geophysical Surveys, 3354 College Rd., Fairbanks, Alaska 99709-3707.
} 


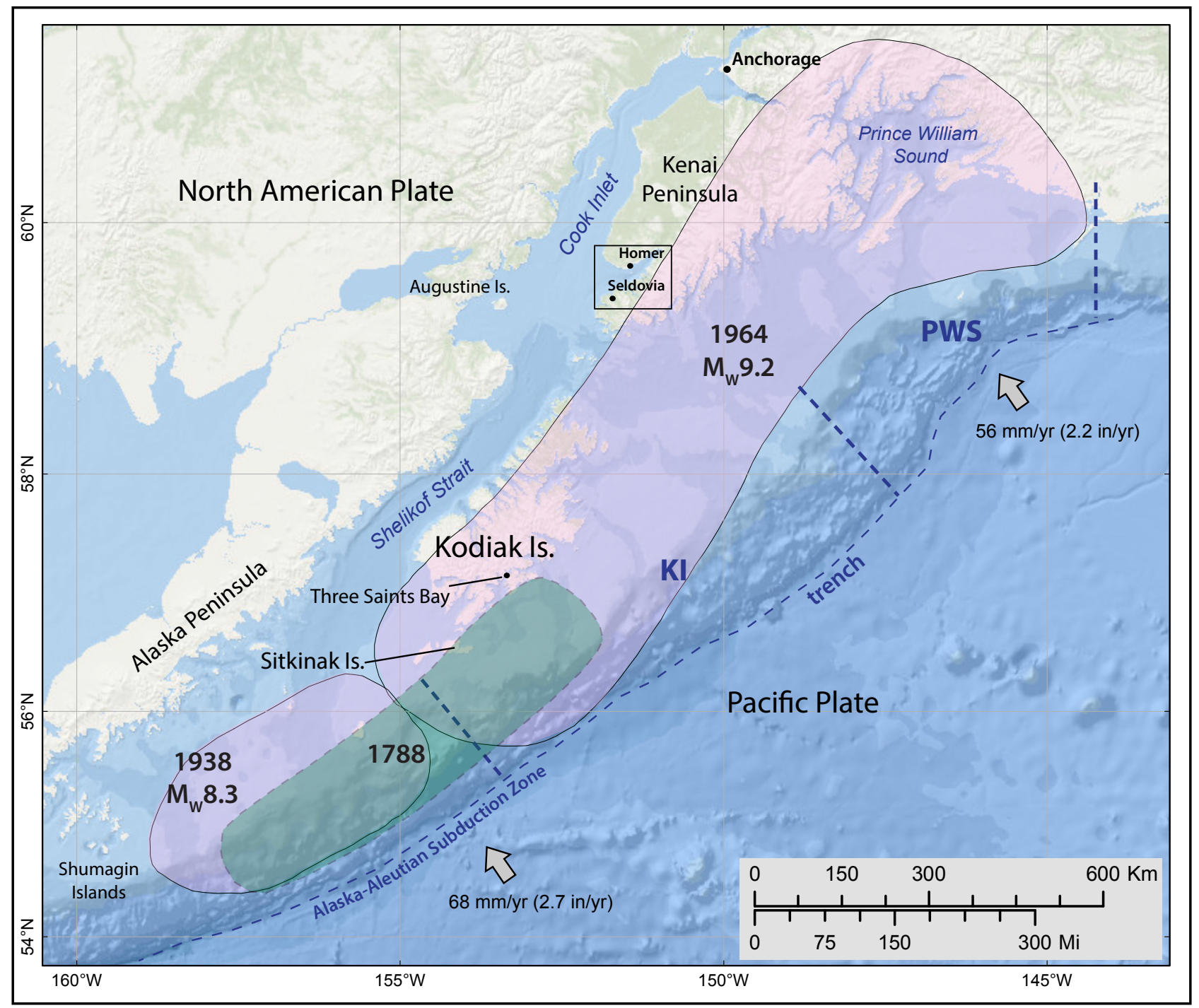

Figure 1. Map of south-central Alaska, showing the location of Kodiak Island, Kenai Peninsula, and the rupture zones of the 1788, 1938, and 1964 Aleutian megathrust earthquakes (shaded areas). The black rectangle marks the area shown in figure 2. $\mathrm{KI}=$ Kodiak Island region; PWS = Prince William Sound region.

after shaking was felt, leaving no time for warning or evacuation. Of the 131 fatalities associated with this earthquake, 122 were caused by tsunami waves (Lander, 1996).

This report updates the previously-published tsunami hazard assessment for Homer and Seldovia, Alaska (Suleimani and others, 2005). In the 12 years since publication of the original report, better bathymetric and topographic data for the Kachemak Bay area became available. Combined with high-resolution continuous global positioning system (GPS) measurements along the southern Alaska coast, the tsunami disasters of
2004 in Indonesia and 2011 in Japan have helped improve our understanding of complex earthquake source mechanisms. Consequently, we include new potential earthquake scenarios in our updated tsunami analysis we develop the worst-case credible tsunami scenarios for coastal communities of the Kachemak Bay area (fig. 2).

The intended audience of this report is scientists, engineers, and planners interested in an applied approach to developing tsunami inundation and evacuation maps. Digital data and documentation provided with the report allow technical users to explore the range of tsunami inundation possible for 
future events. The methodologies used to develop tsunami inundation maps are described in detail in multiple publications and are not reviewed in this report. Refer to Suleimani and others (2016) for a complete description of the process.

\section{PROJECT BACKGROUND: REGIONAL AND GEOLOGICAL CONTEXT}

\section{Regional Setting}

The picturesque city of Homer sits on the north shore of Kachemak Bay, overlooking the mountains and glaciers of Kenai Fjords National Park on the southern Kenai Peninsula. The town of just over 5,000 inhabitants is at the end of the Sterling Highway, 365 road km (227 mi) southwest of Anchorage (fig. 1). According to the Alaska community database (www.commerce.alaska.gov/ dcra/DCRAExternal/community), the city of Homer grew from a community of gold prospectors who arrived at the turn of the 20th century and settled on and around Homer Spit, a 7.2 kilometer-long ( $4.5 \mathrm{mi})$ needle of land stretching halfway across Kachemak Bay (fig. 2). Various mining operations continued until World War I, after which settlers continued to trickle into the area to homestead and work in the canneries built on Homer Spit to process Cook Inlet fish.

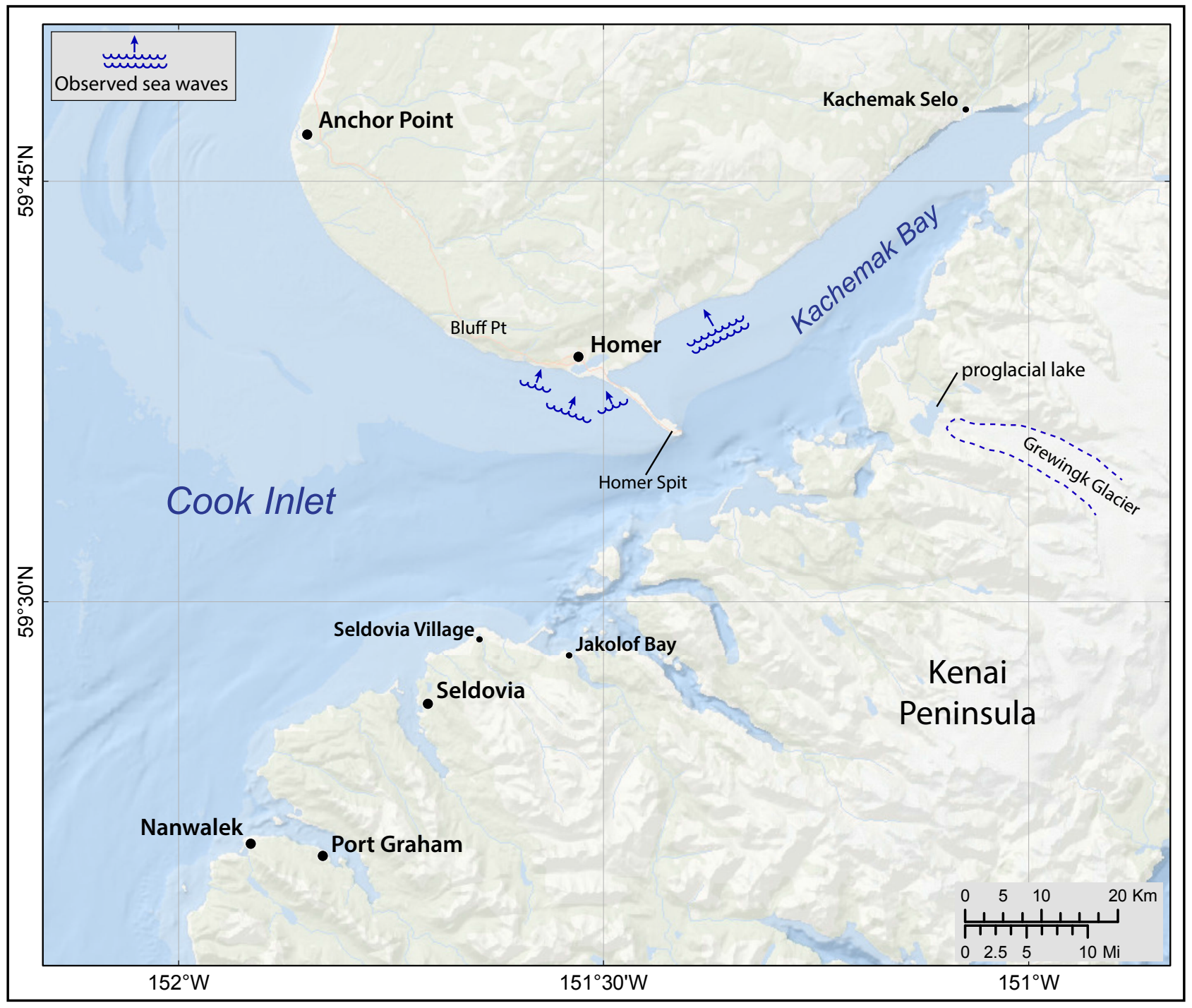

Figure 2. Map of lower Cook Inlet and Kachemak Bay. The blue pictograms indicate waves in Cook Inlet and Kachemak Bay that were observed within 5-10 minutes after the March 27, 1964 earthquake (from Waller, 1966). Arrows show the direction of the wave travel. 
Although commercial fishing has remained the mainstay of the Homer economy, tourism has become increasingly important in recent years. Today most of the community is spread over the south-facing slopes and bluffs of the surrounding hillside, while Homer Spit hosts a variety of tourist and commercial fishing businesses as well as a camping and RV park. The harbor located at the end of Homer Spit has a deep-water dock, a cruise ship dock, moorage for 920 vessels, and a 4-lane boat launch. The city also has a commercial airport with both an asphalt runway and seaplane base at Beluga Lake that each host daily scheduled and chartered air services.

Seldovia sits across from Homer (fig. 2) on the southern shore of Kachemak Bay. It is one of the oldest settlements in the Cook Inlet area, dating back to the mid-1800s as a Russian trading post. Seldovia is an Alutiiq Native village of just over 200 people, where commercial and subsistence fishing are integral parts of the local culture. Access to Seldovia is via air from Homer (15 minutes) or Anchorage (45 minutes), or via water taxi from Homer. The state ferry system also connects Seldovia to Homer and the state highway system.

\section{Geological Setting Tsunamigenic Earthquakes}

The Kenai Peninsula is located at the eastern end of the Alaska-Aleutian subduction zonethe tectonic boundary along which the Pacific plate subducts beneath the North American plate (fig. 1). In fact, the Kenai Peninsula is located directly above the plate interface (or megathrust) that is the source of great $(M>8)$ historical earthquakes in southern Alaska (fig. 1). Motion of the Pacific plate relative to the North American plate in the Cook Inlet region, a process driven by the motion of Earth's tectonic plates, reaches -5.6 $\mathrm{cm} /$ year ( $-2.2 \mathrm{in} /$ year; Freymueller and others, 2008). These overall plate motions give rise to continuing cycle of storing and releasing energy in earthquakes. Because major earthquakes occur infrequently at human timescales, researchers also focus their attention on the deformation of plate boundaries between earthquakes (the interseismic period) as well as on the earthquake events.

A simplified representation of the earthquake cycle is shown in figure 3. A cycle begins shortly after an earthquake at the start of the interseismic period (fig. 3A). Friction between the two plates causes them to couple together in a so-called "locked zone." Because the plates are continuously converging but locked at the fault, the stress imparted to the locked zone results in a buildup of elastic strain energy in the surrounding plates and causes a characteristic pattern of deformation-regions of uplift and subsidence at the plate boundary (fig. 3B). The rate and distribution of this deformation are now the focus of high-precision geodetic studies. When this strain becomes sufficient to overcome the friction holding the plates together, the fault slips. During an earthquake this movement occurs abruptly, with slip of up to several tens of meters in great earthquakes (>M8) that radiate seismic waves and rapidly change the position of the seafloor (fig. 3C). The magnitude of the earthquake is determined by the along-arc length of the rupture, its up-dip and down-dip extent, and the amount of slip along each patch of the fault. When the plates come to rest after the earthquake, the cycle begins again.

Research since the 1990s has demonstrated that the "stick-slip" nature of these faults can be more complicated than the simple model presented in figure 3. In particular, studies of plate deformation between great earthquakes demonstrate that some patches of the fault can slip, or creep, quietly without accumulating significant strain (fig. 4). The result is a fault that consists of variably locked and creeping zones, each with different potential for slip during great earthquakes. The majority of slip during great earthquakes seems to occur in the locked regions, also known as asperities. An individual earthquake may span one or more of these asperities, and may or may not adopt a constant rupture pattern across multiple earthquake cycles. The repeatability of earthquake ruptures and the interplay of different 

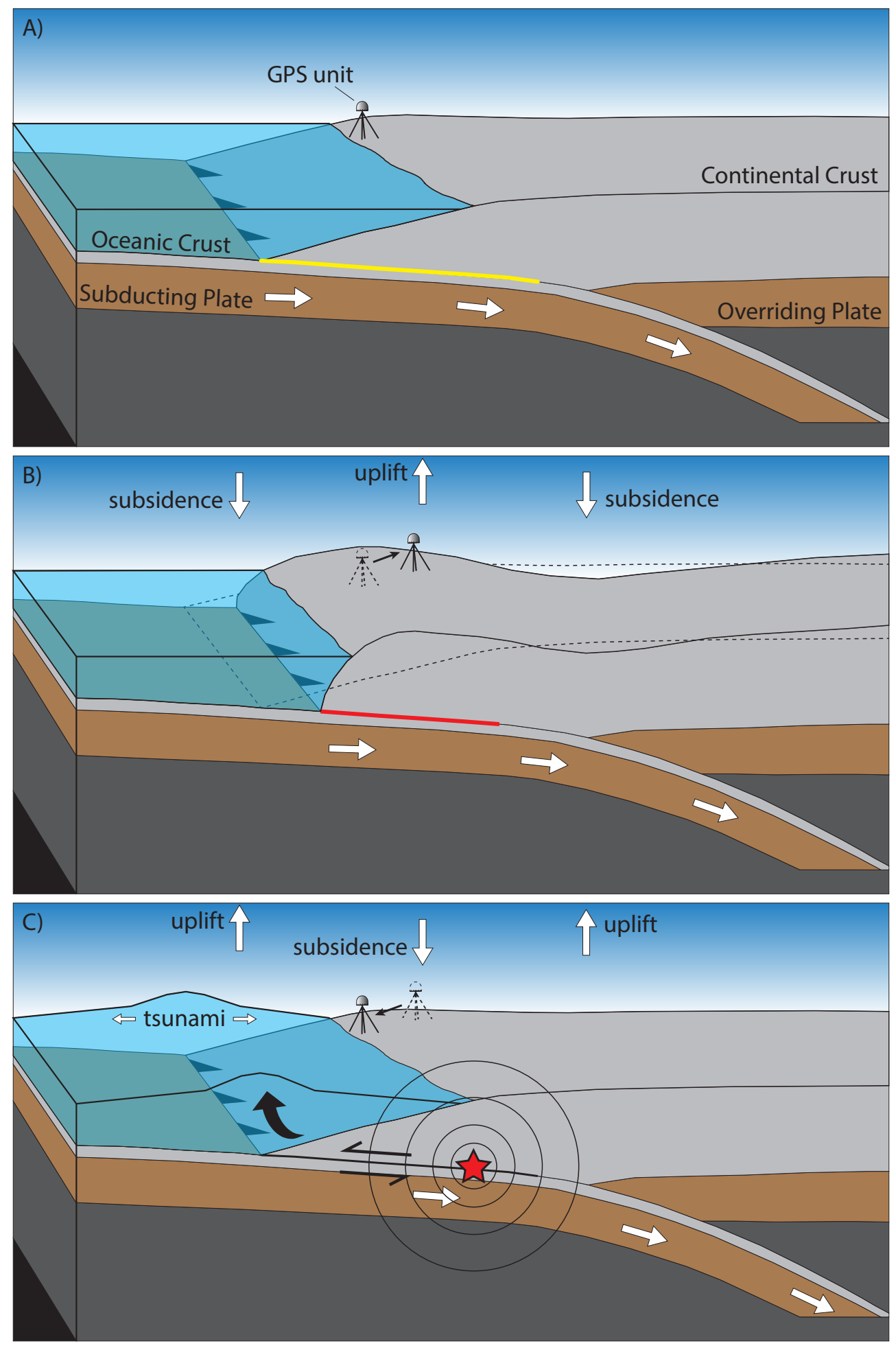

Figure 3. Cartoon illustration of a megathrust earthquake cycle where the overriding plate is considered stationary. A. Cycle begins immediately after an earthquake event (no accumulated strain). Dense, thin, oceanic crust is subducted beneath the less-dense, thicker, continental crust. The yellow line indicates the extent of the plate interface that will become "locked" due to friction. B. Continued subduction (during the interseismic phase) at the coupled plate interface (red line) leads to an accumulation of elastic strain energy in the overriding plate. This causes a measurable amount of deformation in the continental crust. $\boldsymbol{C}$. The friction on the plate interface is overcome and the fault ruptures, releasing elastic strain energy that was stored in the upper crust, deforming the overriding plate. Slip on the fault causes shaking and vertical deformation of the seafloor that can generate a tsunami. 
asperities and creeping zones through time are the subjects of intense ongoing research.

We operate on the assumption that what happened in the past could potentially happen again, however, we also know that earthquakes do not necessarily repeat themselves. The models used here incorporate past earthquake behavior and also address the range of behaviors that are considered geologically plausible in the immediate future.

\section{The 1964 Earthquake and Tsunami}

The segment of the megathrust along the Alaska mainland has produced a record of great earthquakes spanning several cycles. The most recent of these, in 1964, provided an unprecedented, if sobering, set of detailed scientific observations. On March 27, 1964, south-central Alaska was struck by the largest earthquake ever recorded in North America. This $\mathrm{M}_{\mathrm{W}} 9.2$ megathrust earthquake (fig. 1) generated a destructive tsunami that caused fatalities and great damage in Alaska, Hawaii, and the west coasts of the United States and Canada. The earthquake ruptured an -800 km-long (-500 mi-long) section of the Aleutian megathrust, producing vertical displacements over an area of about $285,000 \mathrm{~km}^{2}(110,039$ $\mathrm{mi}^{2}$ ) in south-central Alaska (Plafker, 1969) (fig. 5). The area of coseismic subsidence included Kodiak Island (KI), Kenai Peninsula, Cook Inlet, and part of northern Prince William Sound (PWS). The major zone of uplift was seaward of the subsidence

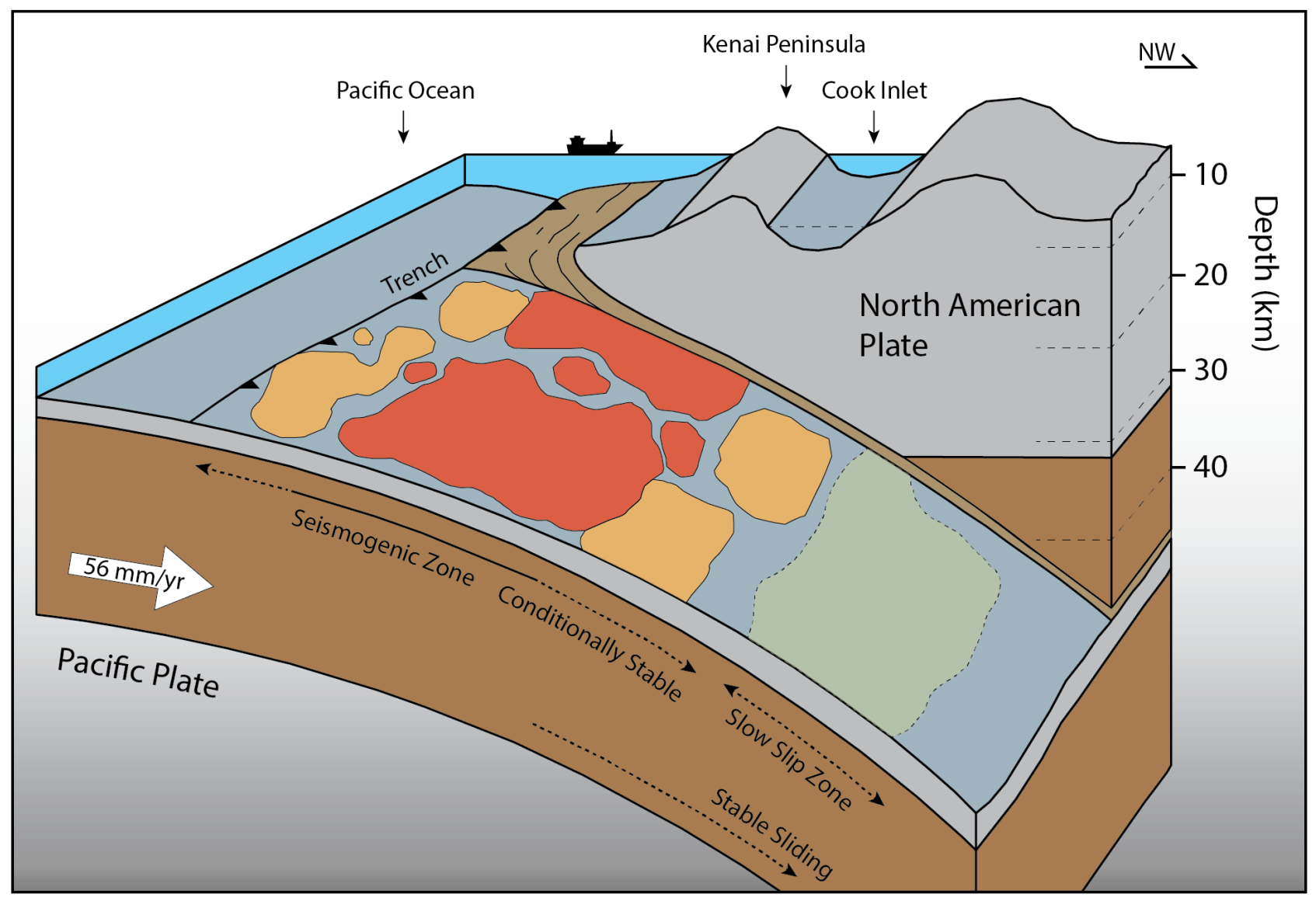

Figure 4. Schematic three-dimensional representation of asperities on a subduction zone plate interface. The colored patches on the plate interface represent three general types of asperities. Red-locked, seismogenic asperities that may rupture independently or in conjunction with other nearby asperities. Orange-conditionally stable, partially locked asperities that may rupture with neighboring seismogenic asperities. Green-deep, slow-slip asperities that may steadily slip, or creep, between earthquake events. Note the depths are for reference and the figure is not to scale. 
zone, in PWS and the Gulf of Alaska (Plafker, 1969). A number of coastal communities suffered greatly from the resulting tsunami waves.

The 1964 Great Alaska Earthquake caused land subsidence on the Kenai Peninsula, as well as along Cook Inlet, Kodiak Island, and in northern PWS. While damage in Homer itself was light compared to other communities in the rupture zone, Homer Spit suffered significantly, subsiding by almost $2 \mathrm{~m}(6 \mathrm{ft})$ due to a combination of coseismic subsidence and ground compaction (Waller, 1966). The subsidence of the spit caused many buildings and structures to be flooded during subsequent high tides, and repair and rehabilitation of public facilities located there cost
$\$ 1,565,000$ (more than $\$ 12 \mathrm{M}$ in 2017 dollars). Tectonic subsidence was responsible for almost all the damage to Seldovia, where it measured around $1 \mathrm{~m}(3.5 \mathrm{ft})$. The boardwalk and all buildings along it became subject to flooding at high tides, as did one end of the airport runway (Plafker and others, 1969).

Hydrologic effects in the area consisted of submarine landslides at the end of Homer Spit and seiche waves. Waller (1966) summarized the observed wave pattern in Cook Inlet and Kachemak Bay: "Exceptional sea waves, both in Cook Inlet and Kachemak Bay, were seen by various observers. Inasmuch as the waves were observed within 5-10 minutes after the quake, the waves clearly did not

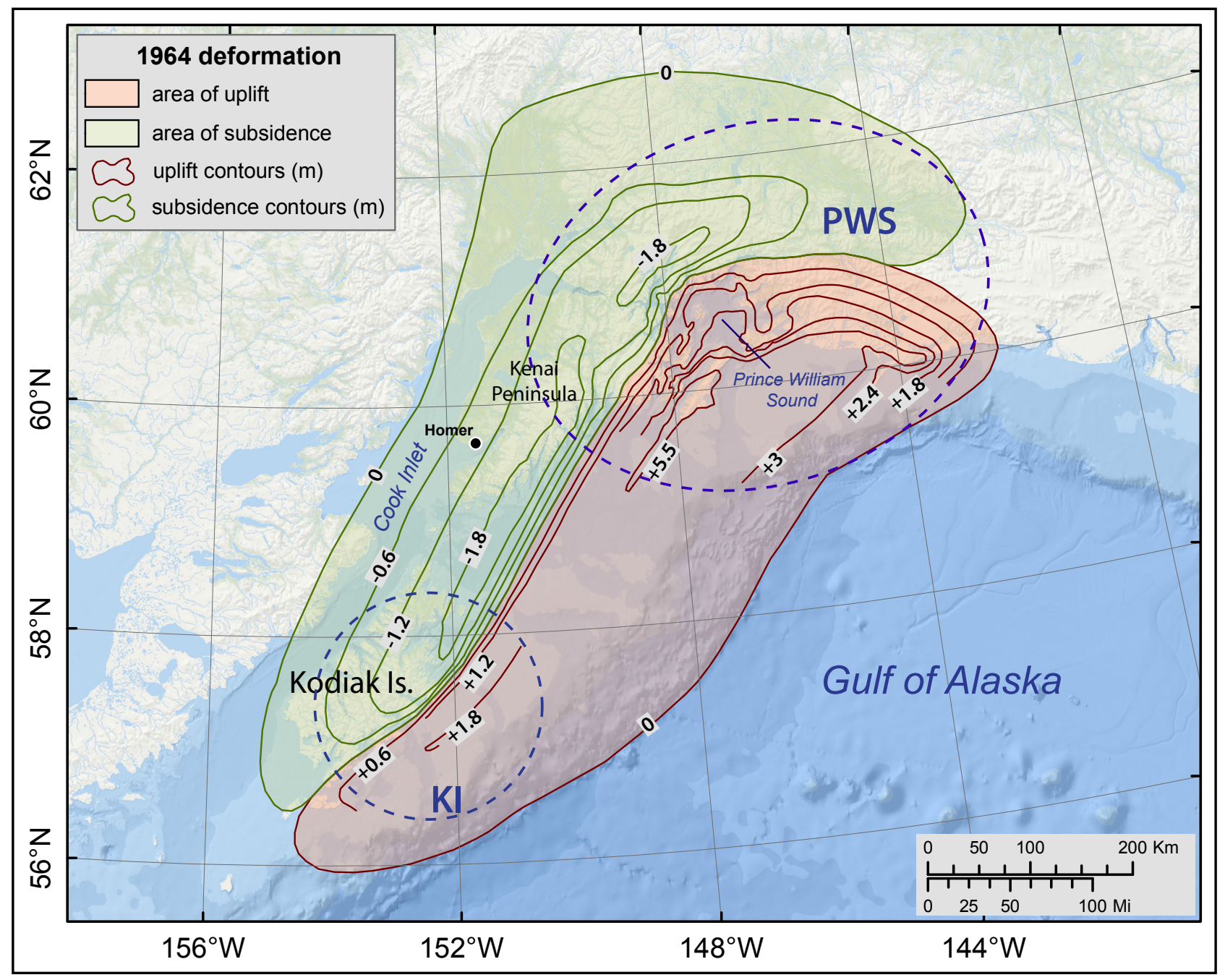

Figure 5. Measured coseismic deformations of the 1964 earthquake from Plafker (1969) and two major asperities of the 1964 rupture zone. 
originate near the epicenter, 160 miles distant. On the other hand, some reported waves apparently came in from the open ocean. Submarine slumping occurred off the tip of the Homer Spit. The possibility of larger scale slumping or landsliding, or both, in uninhabited parts of Cook Inlet cannot be disregarded." We diagrammatically reproduce the wave pattern reported by Waller (1966) in figure 2. The U.S. Coast and Geodetic Survey (1964, p. 82) reported from news excerpts that "Ten-foot waves at 2-minute intervals occurred at about the same time the ground shock was felt." This report agrees with Stanley's (1965) statement that the waves immediately after the earthquake were $2.7 \mathrm{~m} \mathrm{(} 9 \mathrm{ft}$ ) high in Cook Inlet and $1.2 \mathrm{~m}$ (4ft) high in Kachemak Bay. All except one of the observed waves were parallel to the north shore. Damage from the landslide activity included the loss of the small-boat harbor breakwater and subsidence of an area west of the Salty Dawg that collapsed by approximately $3 \mathrm{~m}(10 \mathrm{ft})$ (Waller, 1966). In Seldovia, tsunami waves carried away the floats of the small-boat harbor, inundated part of the boardwalk, and damaged stock in a few stores. Table 1 summarizes historically recorded tsunami events that reached Homer and Seldovia in the past.

\section{Geodetic Studies}

Using seismic waveform data, Christensen and Beck (1994) showed that there were two areas of high moment release during the 1964 Great Alaska Earthquake, representing the two major asperities of the 1964 rupture zone: the Prince William Sound (PWS) asperity with an average slip of $18 \mathrm{~m}(59 \mathrm{ft})$, and the Kodiak Island (KI)

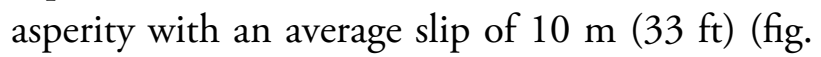
5 ). The results of joint inversion of tsunami and geodetic data from the 1964 earthquake (Johnson and others, 1996) also suggest two areas of high moment release.

Zweck and others (2002) used a three-dimensional elastic dislocation model to demonstrate that modern GPS data in southern Alaska can be satisfied by the presence of a locked area near southwest PWS and a locked area near southwest Kodiak Island. They found that locked areas correspond to the PWS and KI asperities that ruptured in 1964, and locked regions may repeat from one earthquake cycle to another. The authors showed that site velocities on Kodiak Island are consistent with a model of locked elastic strain accumulation in the area of plate locking near Kodiak Island.

The most recent deformation model of the 1964 earthquake was introduced by Suito and Freymueller (2009). This model was developed as a three-dimensional viscoelastic model in combination with an afterslip model, using realistic geometry with a shallow-dipping elastic slab. The study described decades of postseismic deformation following the 1964 earthquake. Important modifications in fault geometry resulted in a revision of the 1964 coseismic model. The authors used the inversion-based model by Johnson and others (1996) as a basis for their coseismic slip model, adjusting it to the new geometry and critically reinterpreting the coseismic data. One critical change was the extension of the Montague Island high-angle splay fault from its subaerial outcrop to a longer length along the southern Kenai Peninsula coast to explain the pattern of subsidence in this area. The authors preferred forward finite-element modeling for calculation of coseismic slip due to inconsistency and systematic errors in coseismic displacement data. At the same time, their resulting slip distribution resembles that derived from inversion models of Holdahl and Sauber (1994), Johnson and others (1996), and Ichinose and others (2007).

\section{Paleoseismology}

Recent paleoseismological findings indicate that prehistoric and historical earthquakes that occurred on the Kodiak segment of the Aleutian megathrust have different spatial patterns of coseismic deformation, in both along-strike and down-dip directions (Briggs and others, 2014; Shennan, Bruhn, and others, 2014). The 
Table 1. Tsunami effects for Homer and Seldovia; data from the National Geophysical Data Center Global Historical Tsunami Database (NCEI/WDS, in progress) and comments from Lander (1996).

\begin{tabular}{|c|c|c|c|c|}
\hline Date & Magnitude $\left(\mathbf{M}_{\mathbf{w}}\right)$ & Origin & $\begin{array}{c}\text { Maximum Water } \\
\text { Height }(\mathbf{m})\end{array}$ & Comments \\
\hline \multicolumn{5}{|c|}{ Homer } \\
\hline $03 / 28 / 1964$ & 9.2 & Gulf of Alaska & 6.0 & $\begin{array}{c}\text { Small-boat harbor } \\
\text { destroyed }\end{array}$ \\
\hline $03 / 28 / 1964$ & 9.2 & Gulf of Alaska & 1.2 & $\begin{array}{c}\$ 500,000 \text { damage, } \\
\text { mostly to boats }\end{array}$ \\
\hline $02 / 27 / 2006$ & 8.8 & Chile & 0.12 & \\
\hline $03 / 11 / 2011$ & 9.1 & Japan: Honshu & 0.1 & \\
\hline
\end{tabular}

penultimate tsunami event in the Gulf of Alaska was recorded on July 21,1788 , when a strong earthquake near Sitkinak Island caused a 3-10 m (10-33 $\mathrm{ft}$ ) tsunami that forced relocation of the first Russian settlement at Three Saints Bay on southwestern Kodiak Island (Lander, 1996) (fig. 1). Briggs and others (2014) present stratigraphic evidence of land level change and ${ }^{137} \mathrm{Cs}$ and ${ }^{210} \mathrm{~Pb}$ bracketing ages of a sand deposit that can be traced $1.5 \mathrm{~km}(0.9 \mathrm{mi})$ inland on Sitkinak Island (fig. 1), and suggest that the 1788 earthquake was a large megathrust rupture that generated the tsunami.

Analysis of historical earthquake data in the PWS and KI segments (Nishenko and Jacob, 1990) showed that the KI segment produced significant megathrust earthquakes more frequently than, and also independently of, the PWS segment. Paleoseismic data show that the KI segment ruptured independently in a large earthquake about 500 years ago-about 360 years more recently than the penultimate great earthquake that ruptured both the KI and PWS segments (Carver and Plafker, 2008). The PWS and KI segments have different recurrence intervals, with estimates of the recurrence interval for $M_{S} 7.5-8$ earthquakes in the KI segment being as low as 60 years (Nishenko, 1991).

On the basis of all published paleoseismic data for the region, Carver and Plafker (2008) calculate that median intervals between the past eight great earthquakes $\left(M_{W}>8\right)$ in the PWS segment of the eastern Aleutian seismic zone range from 333 to 875 years, with an average of 589 years. Shennan, Barlow, and others (2014) analyzed new paleoseismic field data from three sites in the PWS segment and revised the dates and recurrence intervals of great earthquakes in the PWS segment. Their results suggest that the intervals range from -420 to -610 years, with a mean of -535 years, excluding the interval between the 1964 earthquake and the penultimate event, which is -883 years.

Shennan, Bruhn, and others (2014) recently presented new paleoseismological data from Kodiak Island, which suggest that intervals between ruptures of the Kodiak segments are shorter than previously assumed, and that the KI segment ruptured more frequently than the PWS segment. The authors tested the hypothesis of Kodiak single-segment ruptures of 1788 and ca. A.D. 1440-1620, both of which occurred between multi-segment ruptures of the 1964 earthquake and the earthquake of ca. A.D. 1020-1150, when the PWS and KI segments ruptured together (Carver and Plafker, 2008; Shennan, Barlow, and others, 2014). Shennan, Bruhn, and others (2014) also analyzed the patterns of uplift and subsidence for the three most recent events on the KI segment-the 1964, 1788, and ca. A.D. 14401620 earthquakes - and found that the location of 
the hinge line, or the contour of zero deformation, was different for all three events.

\section{Landslide-Generated Tsunami Hazards}

Tsunamis caused by underwater slope failures constitute a significant hazard in the fords of coastal Alaska and other high-latitude fjord coastlines (Lee and others, 2006). Slope failures may occur without a distinct trigger, such as an earthquake, but if an earthquake does cause local landslides, the resulting tsunamis may arrive with or immediately after shaking. There may be no time for warning or evacuation.

During the 1964 Great Alaska Earthquake, multiple tsunamis were caused by local submarine slides and were responsible for most of the tsunami-related damage and loss of life. For the sake of brevity, we refer to Nicolsky and others, (2013, $2017)$ and Suleimani and others $(2010,2016)$ for an overview of the landslide tsunami hazard in Alaska communities.

In Homer, one and possibly two submarine landslides occurred during the 1964 earthquake at the distal end of Homer Spit (Waller, 1966). However, the corresponding landslide-generated waves at the Homer spit were not as destructive as those in Valdez where the runup of a landslide-generated tsunami locally reached $52 \mathrm{~m}(-170 \mathrm{ft})$. One of the landslides in Homer was responsible for the loss of a wave breaker at the small-boat harbor. Waller (1966) says that "another slide occurred west of the Salty Dawg saloon; the land collapsed by approximately $3 \mathrm{~m}$ (10 ft)." Traces of both slides are shown in figure 6 , which also demonstrates the integrity of Homer Spit could be severely strained in a future earthquake.

We identify signatures of submarine slides in the bathymetric map as irregularities, or scars, visible on the underwater slopes. The most prominent landslide scars are along the southeast-facing flank of the end of the spit (figure 7A). There are other scars along the northeast flank of the end of the spit near the entrance to the small-boat harbor. Because we see evidence for recent mass failures, we hypothesize that areas near the tip of the spit are prone to underwater slope failures.

Across Kachemak Bay, glacial rivers drain into the ocean and build submarine deltas. Oversteepened slopes of fine-grained, unconsolidated sediments are known to have a high risk of collapse. The bathymetry near the Wosnesenski River and

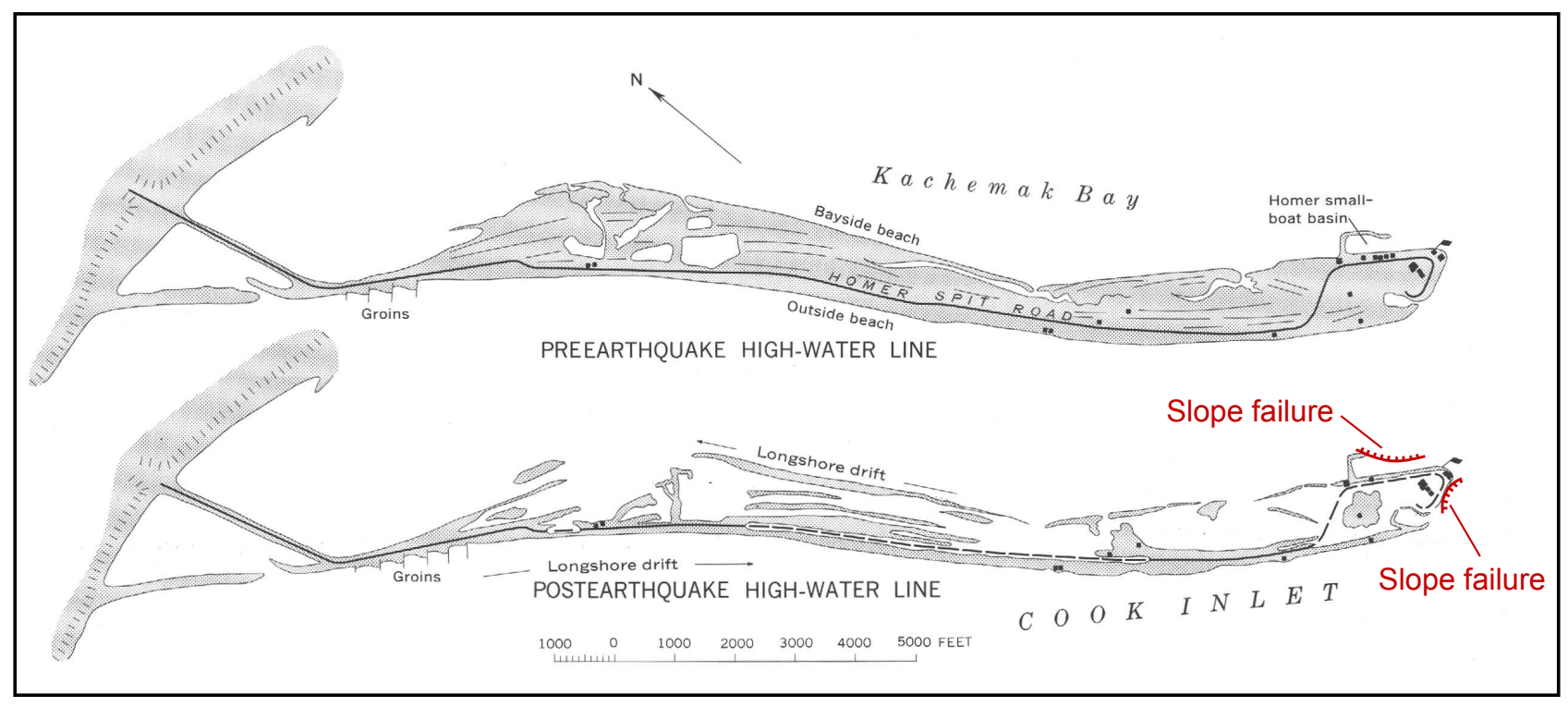

Figure 6. Sketch of Homer Spit showing locations of slope failures that occurred during the 1964 earthquake (modified from Waller, 1966). 
Grewingk Creek deltas contains features such as steep slopes, hummocky ocean bottom, and potential evidence of previous slumping across the delta toes (figure 7B). Therefore, the Wosnesenski River and Grewingk Creek deltas are thought to be locations of potential underwater landslides, analogous to deltas of Resurrection and Lowe rivers that were locations of underwater slope failures triggered by the 1964 earthquake (Suleimani, 2011; Nicolsky and others, 2013).

Coastal areas in Alaska are also prone to tsunami waves generated by subaerial rockfalls. Cossart and others (2008) found that glacial unloading and associated stress release play an important role in triggering rock-slope failures. One of the largest historical tsunami waves (generated by a subaerial rock-slope failure in Lituya Bay) occurred in 1958 and exceeded $530 \mathrm{~m}(1,740 \mathrm{ft})$ (Miller, 1960). Another massive subaerial landslide occurred near Tyndall Glacier in Taan Fjord-an arm of Icy Bay-in October 2015 (press release, University of Alaska Fairbanks, www.gi.alaska. edu/alaska-science-forum/giant-wave-icy-bay). The Kachemak Bay area also experienced a similar event in the past: in the fall of 1967, more than 84 million $\mathrm{m}^{3}\left(2,966 \mathrm{ft}^{3}\right)$ of rock and debris crashed onto the Grewingk Glacier toe (fig. 2) from a valley wall and then slid into a proglacial lake (Wiles and Calkin, 1992). The slide produced a major flood wave more than $60 \mathrm{~m}(197 \mathrm{ft})$ high, which swept down the uninhabited valley.

The combination of high sedimentation rates, seismic activity, and history of submarine landslides led us to identify potential slide source areas in Kachemak Bay, as shown in figure 8. Later in the report, we describe submarine landslide-generated tsunami scenarios in more detail and analyze results of numerical modeling of slide-generated waves.

\section{Volcano-Generated Tsunami Hazards}

Homer and Seldovia are directly across Cook Inlet from Augustine volcano, a 1,200 m (4,000 ft) steep-sided stratovolcano that last erupted in 2006 (fig. 1). Augustine Island is on the western side of Lower Cook Inlet $\sim 110 \mathrm{~km}(\sim 70$ miles) west-southwest of Homer and $-100 \mathrm{~km}(-60$ miles) west of Seldovia. While eruptions typically involve intermittent ash-producing explosions and lava extrusion lasting days to weeks (Buurman and West, 2010), historical records show that volcanic activity at Augustine can cause landslides capable of generating tsunami waves (Begét and Kienle, 1992).

The 1883 eruption of Augustine Volcano produced a landslide that triggered a tsunami. The tsunami struck the settlement of English Bay (present-day Nanwalek), $40 \mathrm{~km}(25 \mathrm{mi})$ southwest of Homer (fig. 2), and was described in the daily log of the Alaska Commercial Company trading post: "At this morning at 8:15 o'clock, 4 Tidal waves flowed with a westerly current, one following the other at the rate of 30 miles p. hour into the shore, the sea rising 20 feet above the usual Level. At the same time the air became black and foggy, and it began to thunder. With this at the same time it began to rain a finely Powdered Brimstone Ashes, which lasted for about 10 minutes, and which covered all the parts of Land and everything to a depth of over $1 / 4$ of a inch." Luckily for the residents of English Bay, the 1883 tsunami occurred during low tide when the water level was several meters below the high tide level, and no fatalities and only minimal damage occurred. The average daily tidal range in Nanwalek is $3.6 \mathrm{~m}$ (11.9 ft). Kienle and others (1996) performed numerical modeling of the 1883 tsunami for different tide conditions and confirmed that the spit would have been flooded if the 1883 tsunami occurred at high tide.

Studies of shoreline deposits around the Cook Inlet area have shown that the 1883 tsunami is not the only volcano-generated tsunami to have occurred in the past 2000 years. Augustine Volcano is considered by Begét and others (2008) to have produced debris avalanches large enough to trigger tsunami waves in Cook Inlet every 150-200 years. Waythomas and others (2006) evaluated the process of tsunami generation with a gravity-driven model of mass flows and their motion down the slope of 
Report of Investigation $2018-5$ v. 2

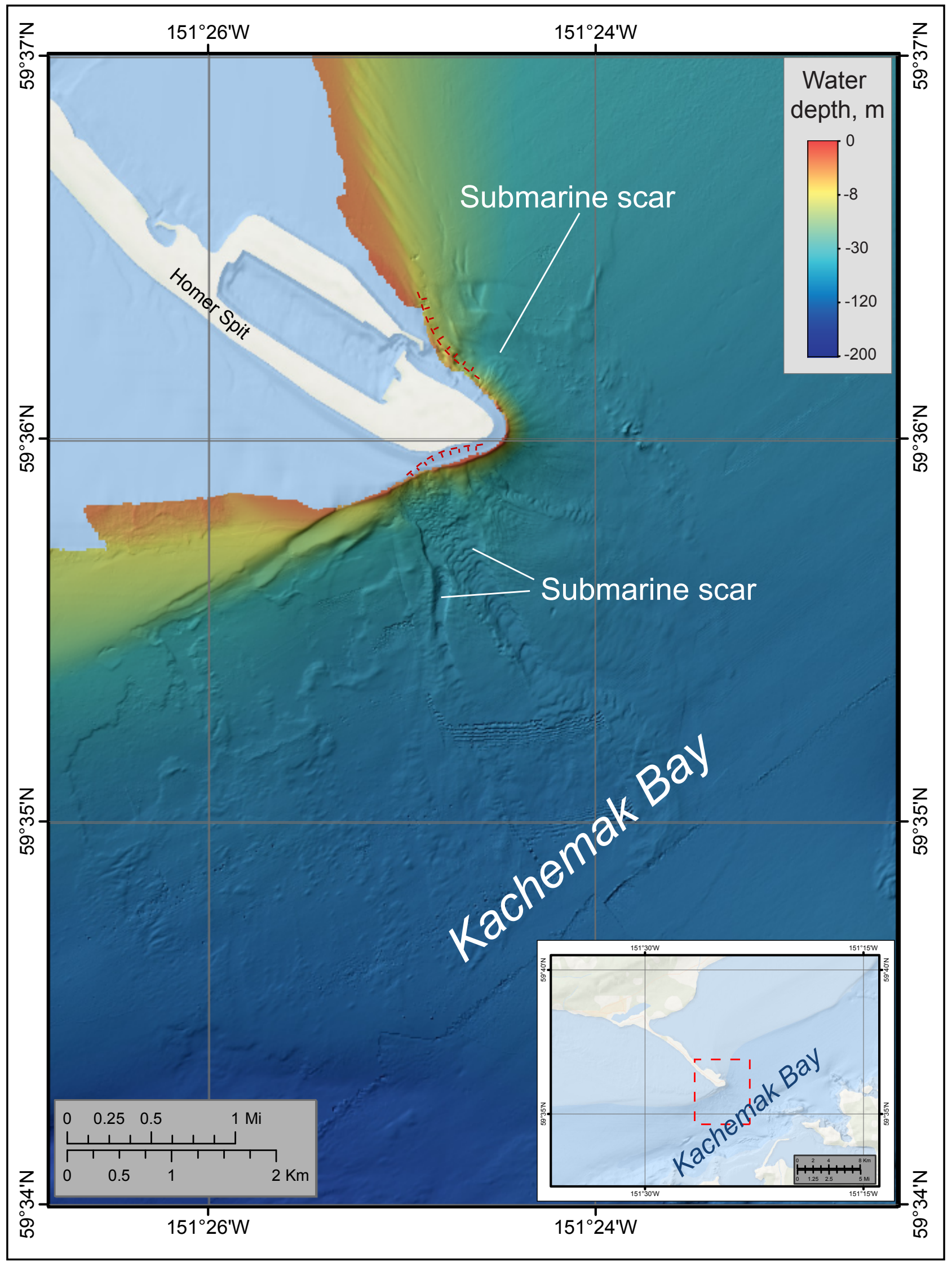

Figure 7A. Bathymetric map of Kachemak Bay around the tip of Homer Spit, showing submarine landslide scars. 


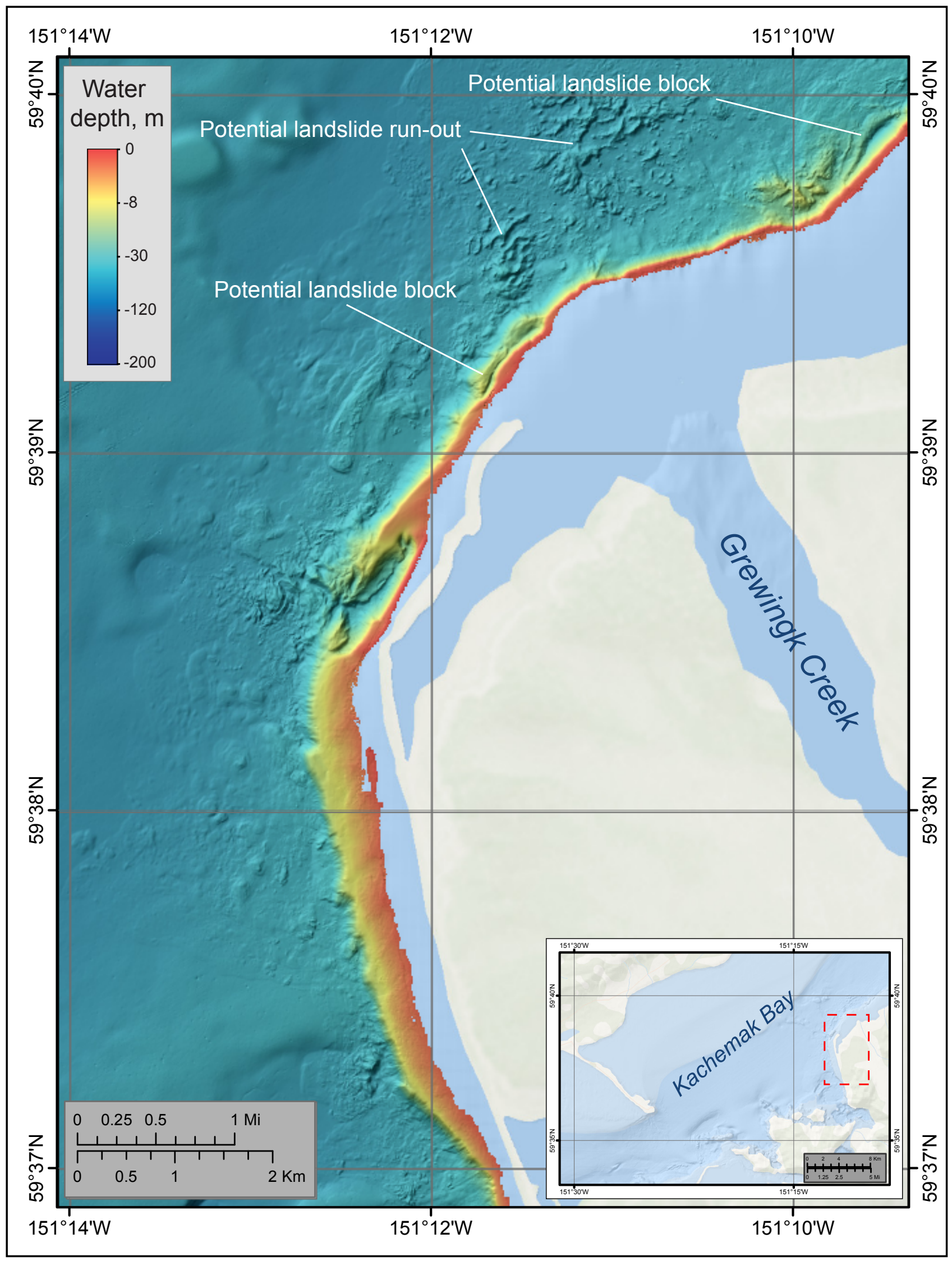

Figure 7B. Bathymetric map of Kachemak Bay in the area of Grewingk Creek, across the bay from Homer. Bathymetric irregularities include hummocky ocean bottom and potential landslide blocks. 


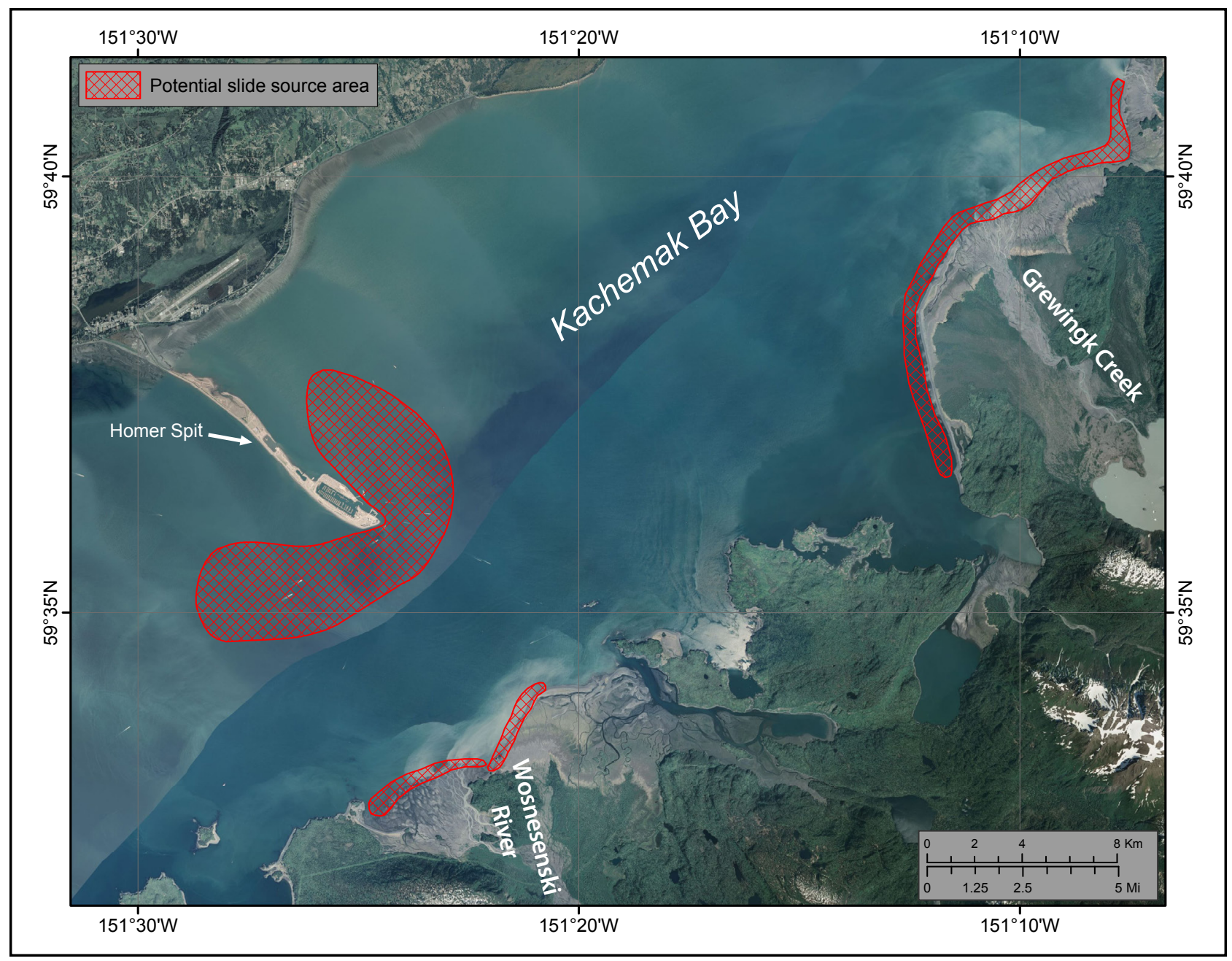

Figure 8. Potential source locations of underwater slides in the vicinity of Homer.

Augustine Volcano to the shoreline. Suleimani and others (in review) use the initial tsunami amplitude and wavelength derived by Waythomas and others (2006) to model hypothetical tsunamis that could reach Homer and Seldovia. They considered two hypothetical slides that enter the sea from the eastern and northeastern flanks of the volcano. Each of these hypothetical debris flows has a volume of $1.25 \times 10^{8} \mathrm{~m}^{3}$, and the maximum initial wave height they produce is $20 \mathrm{~m}(66 \mathrm{ft})$, an estimate that is limited by the water depth around Augustine Island in the run-out zone of the modeled debris avalanches (Waythomas and others, 2006). The numerical modeling results show that for the given volume of slide, the maximum wave heights at Homer and Seldovia are expected to be about $1 \mathrm{~m}(3 \mathrm{ft})$.

\section{METHODOLOGY AND DATA Grid Development and Data Sources}

We use a series of nested computational grids around Homer and Seldovia to generate a detailed map of potential tsunami inundation triggered by local and distant earthquakes. The coarsest grid, with 2-arc-minute (approximately $2 \mathrm{~km}$ [ $-1.2 \mathrm{mi}]$ ) resolution, spans the central and northern Pacific Ocean. We used three intermediate grids between the coarsest- and highest-resolution grids (table 2; fig. 9A). The areas covered by the highest-resolution grids for Homer and Seldovia, termed "level 4 grids," are shown by shaded rectangles in figure 9A. The spatial resolution of these high-resolution grids, with about $14 \times 16 \mathrm{~m}(49.2 \times 52.4 \mathrm{ft})$ 
cells, satisfies National Oceanic and Atmospheric Administration (NOAA) minimum recommended requirements for computation of tsunami inundation (National Tsunami Hazard Mapping Program [NTHMP], 2010). The bathymetric datasets used in grid development include National Ocean Service (NOS) hydrographic surveys, NOAA Electronic Navigational Chart (ENC) soundings, a U.S. Army Corps of Engineers (USACE) harbor survey, and multi-beam swath sonar surveys. More detailed information on grid development is contained in Lim and others (2009).

\section{Numerical Model of \\ Tsunami Propagation and Runup}

To estimate tsunami propagation and runup in Homer and Seldovia, we used the same numerical model previously employed in other Alaska tsunami inundation studies (for example, Suleimani and others, 2010, 2013, 2015, 2016, and Nicolsky and others, 2011a, 2013, 2014, 2015). This model has been validated through a set of analytical benchmarks and extensively tested against laboratory and field data (Nicolsky and others, 2011; Nicolsky, 2012). The model solves the nonlinear shallow-water equations using a finite-difference method on a staggered grid, and uses ocean surface displacement due to an underwater earthquake as an initial condition. All hypothetical tsunami simulations were conducted using the bathymetric/topographic data corresponding to the Mean Higher High Water (MHHW) level in the communities. Because the numerical model does not dynamically simulate interaction of tides and tsunami waves, we use a conservative approach and assume that the tsunami arrives at the communities at high tide. Our previous modeling studies demonstrated that the extent of simulated tsunami inundation is sensitive to parameterization of the bottom drag coefficient, that is, the surface roughness coefficient $\mu$ in the Manning formula (Nicolsky, Suleimani, and Hansen, 2011). In this report we use a value of surface roughness $\mu=0.02 \mathrm{~m}^{1 / 3} / \mathrm{s} \quad\left(0.03 \quad \mathrm{ft}^{1 / 3} / \mathrm{s}\right) \quad$ that corresponds to straight and uniform Earth surface

Table 2. Nested grids used to compute propagation of tsunami waves generated in the Pacific Ocean to Homer and Seldovia. The high-resolution grid is used to compute inundation. Note that the grid resolution in meters is not uniform: the first dimension is the longitudinal grid resolution and the second is the latitudinal resolution. Measurements also vary across each grid and are given for a reference location near Homer to illustrate relative grid resolution.

\begin{tabular}{|c|c|c|c|c|}
\hline \multirow[b]{2}{*}{ Grid Name } & \multicolumn{2}{|c|}{ Resolution } & \multirow{2}{*}{$\begin{array}{l}\text { East-West } \\
\text { Boundaries }\end{array}$} & \multirow{2}{*}{$\begin{array}{c}\text { North-South } \\
\text { Boundaries }\end{array}$} \\
\hline & Arc-Seconds & $\begin{array}{c}\text { Meters } \\
\text { (near Homer) }\end{array}$ & & \\
\hline $\begin{array}{c}\text { Level 0, Northern } \\
\text { Pacific }\end{array}$ & $120 \times 120$ & $\approx 1,875 \times 3,704$ & $\begin{array}{l}120^{\circ} 00^{\prime} 00^{\prime \prime} \mathrm{E}- \\
100^{\circ} 00^{\prime} 00^{\prime \prime} \mathrm{W}\end{array}$ & $\begin{array}{c}10^{\circ} 00^{\prime} 00^{\prime \prime} \mathrm{N}- \\
65^{\circ} 00^{\prime} 00^{\prime \prime} \mathrm{N} \\
\end{array}$ \\
\hline $\begin{array}{c}\text { Level 1, } \\
\text { South-central } \\
\text { Alaska } \\
\end{array}$ & $24 \times 24$ & $\approx 375 \times 741$ & $\begin{array}{l}156^{\circ} 00^{\prime} 00^{\prime \prime} \mathrm{W}- \\
145^{\circ} 00^{\prime} 00^{\prime \prime} \mathrm{W}\end{array}$ & $\begin{array}{l}55^{\circ} 00^{\prime} 00^{\prime \prime} \mathrm{N}- \\
62^{\circ} 00^{\prime} 00^{\prime \prime} \mathrm{N}\end{array}$ \\
\hline $\begin{array}{c}\text { Level 2, Coarse } \\
\text { resolution, Lower } \\
\text { Cook Inlet }\end{array}$ & $8 \times 8$ & $\approx 124 \times 247$ & $\begin{array}{l}153^{\circ} 28^{\prime} 32^{\prime \prime} \mathrm{W}- \\
151^{\circ} 10^{\prime} 40^{\prime \prime} \mathrm{W}\end{array}$ & $\begin{array}{c}58^{\circ} 48^{\prime} 28^{\prime \prime} N- \\
60^{\circ} 00^{\prime} 44^{\prime \prime} N\end{array}$ \\
\hline $\begin{array}{c}\text { Level 3, } \\
\text { Fine resolution, } \\
\text { Anchor Point }\end{array}$ & $8 / 3 \times 8 / 3$ & $\approx 41 \times 82$ & $\begin{array}{l}153^{\circ} 10^{\prime} 11^{\prime \prime} \mathrm{W}- \\
151^{\circ} 52^{\prime} 45^{\prime \prime} \mathrm{W}\end{array}$ & $\begin{array}{c}59^{\circ} 04^{\prime} 17^{\prime \prime} \mathrm{N}- \\
59^{\circ} 52^{\prime} 23^{\prime \prime} \mathrm{N}\end{array}$ \\
\hline $\begin{array}{c}\text { Level 4, } \\
\text { High resolution, } \\
\text { Homer }\end{array}$ & $8 / 9 \times 1 / 2$ & $\approx 14 \times 16$ & $\begin{array}{l}152^{\circ} 41^{\prime} 32^{\prime \prime} \mathrm{W}- \\
152^{\circ} 09^{\prime} 06^{\prime \prime} \mathrm{W}\end{array}$ & $\begin{array}{l}59^{\circ} 32^{\prime} 51^{\prime \prime} \mathrm{N}- \\
59^{\circ} 40^{\prime} 40^{\prime \prime} \mathrm{N}\end{array}$ \\
\hline $\begin{array}{c}\text { Level 4, } \\
\text { High resolution, } \\
\text { Seldovia }\end{array}$ & $8 / 9 \times 1 / 2$ & $\approx 14 \times 16$ & $\begin{array}{c}152^{\circ} 47^{\prime} 50^{\prime \prime} \mathrm{W}- \\
152^{\circ} 29^{\prime} 35^{\prime \prime} \mathrm{W}\end{array}$ & $\begin{array}{l}59^{\circ} 22^{\prime} 19^{\prime \prime} \mathrm{N}- \\
59^{\circ} 32^{\prime} 08^{\prime \prime} \mathrm{N}\end{array}$ \\
\hline
\end{tabular}


(www.fsl.orst.edu/geowater/FX3/help/8 Hydraulic_Reference/Mannings_n_Tables.htm).

We approach this problem-modeling the outcome of different tsunami-generating scenarios-deterministically. This means we are not focused on calculating the relative likelihood and frequency of various magnitude earthquakes, as is done for land-use planning or insurance estimates (Geist and Parsons, 2006; Geist and Lynett, 2014). Because the known earthquake and tsunami history of Alaska is short, we instead model the results of many hypothetical earthquakes and landslides to explore plausible scenarios based on the regional geology.

\section{Numerical Model of Landslide-Generated Tsunamis}

We simulate wave generation caused by the motion of a viscous landslide down the slope using the NHWAVE fully coupled model (Kirby and others, 2016). At the beginning of each numerical experiment, when the submarine slide initially propagates down the slope, it pushes water and creates a positive wave propagating away from the slide. Behind, at the original slide location, an initial water surface depression occurs and is consequently filled with water under the restoring force of gravity. The wave radiation patterns created by slide dynamics are complex and usually include a series of crests and troughs radiating away from the slide area. We refer to Løvholt and others (2015) for an in-depth description of landslide tsunami generation. When the slide reaches the bottom of the bay, most of its energy has already been transferred to the water. At this moment, execution of the fully coupled model is terminated. The resultant water level and water velocities (depth-averaged across all layers in NHWAVE) are used as initial conditions for the FUNWAVE model. FUNWAVE then models a potential inundation of dry land. The extent of potential inundation from the landslide scenario encompasses the inundation extents of the NHWAVE model and the FUNWAVE model.
We follow the methodology outlined in the tsunami hazard report for Juneau (Nicolsky and others, 2017). Specifically, we use a numerical model developed by Kirby and others (2016) with two fully coupled components: a depth-integrated layer of Newtonian viscous fluid for the landslide model (Jiang and LeBlond 1992; Fine and others, 1998), and a shock-capturing Non-Hydrostatic Wave (NHWAVE) model by $\mathrm{Ma}$ and others (2012). A few minutes after the start of the model, the water level and water velocities (depth-averaged across all layers in NHWAVE) are used as initial conditions for the FUNWAVE-TVD model. FUNWAVE-TVD then models a potential inundation of the dry land with $0.01 \mathrm{~m}(0.4$ in) threshold between dry and wet cells. A similar two-stage approach as used to simulate inundation along the U.S. East Coast (Grilli and others, 2013) and the Gulf of Mexico (López-Venegas and others, 2014) where the sliding area and the coast are not adjacent to each other. Further details regarding the coupling and the choice of parameters used to simulate landslide dynamics can be found in (Nicolsky and others, 2017).

\section{TSUNAMI SOURCES}

\section{Sensitivity Study}

Locating the up-dip limit of the locked zone in the area of Kenai Peninsula is hindered by the lack of geodetic data close to the Aleutian trench. We do not yet have seafloor GPS/acoustic measurements that are necessary to determine the behavior of the uppermost portion of the plate interface. However, recent studies comparing the Alaska and Tohoku tectonic margins (Kirby and others, 2013) suggest that there are several similarities in geologic setting between the two areas, and that a hypothetical rupture might propagate to shallow depths on the Alaska-Aleutian megathrust in a manner similar to the $\mathrm{M}_{\mathrm{W}} 9.0$ Tohoku earthquake. Therefore, in our scenarios, we include earthquakes that rupture the shallow locked zone.

To further assess tsunami hazard for the Kachemak Bay communities, we conduct a 
sensitivity study to determine what effect the down-dip location of a rupture has on tectonic subsidence and uplift and resulting tsunami waves. The results of the sensitivity study are then applied to construct the maximum credible scenarios.

We use a model of the Alaska-Aleutian plate interface that has been originally developed by Hayes and others (2012). We amended the interface, specifically its eastern part, with the depth contour reconstructions and profiles as described in Nicolsky and others (2013). Similar to the plate reconstruction by Zweck and others (2002), our plate interface model exhibits a relatively shallow dip angle beneath Kodiak Island and the Kenai Peninsula until it reaches a depth of $50 \mathrm{~km}(31 \mathrm{mi})$ where it transitions to steeper dip (fig. 9B).

The plate interface is discretized into a mesh of rectangles ranging from 3 to $6 \mathrm{~km}(1.9-3.7 \mathrm{mi})$ in the along-strike direction of the plate interface. The upper and lower edges of each rectangle coincide with depth contours of the plate interface that are spaced at $1 \mathrm{~km}(0.6 \mathrm{mi})$. The rectangles, called subfaults, are later used to compute coseismic ground deformation (Okada, 1985). Using this discretization of the plate interface, we can model potential earthquake scenarios by first prescribing a general pattern of slip distribution in the proposed rupture, and then computing the slip at the center of each subfault using seismic moment as a constraint.

Earthquake ruptures with slip at different depths result in different distributions and amounts of subsidence and uplift in coastal communities, and therefore in different tsunami and permanent flooding characteristics. We develop four different slip cases (cases A-D) for $\mathrm{M}_{\mathrm{W}} 8.0$ earthquakes between Kodiak Island and Kenai Peninsula, and calculate vertical deformations associated with each case (fig. 10). To keep the seismic moment constant for these four cases, we vary the total amount of slip according to the overall rupture area. The width of the rupture area is defined as the down-dip distance between any two depth contours that are $10 \mathrm{~km}(6.2 \mathrm{mi})$ apart.
Because this distance decreases with depth due to increasing dip values, slip cases that are deeper on the subduction interface have greater amounts of slip. The relative slip distribution for all four cases is identical: uniform in the along-strike direction, with tapering at the ends of the rupture and a symmetrical bell-type slip curve in the downdip direction. Between any two consecutive cases, the hypothetical rupture is offset by about $10 \mathrm{~km}(6.2$ $\mathrm{mi}$ ) in the downdip direction: case A corresponds to a rupture at $10 \mathrm{~km}(6.2 \mathrm{mi})$ depth, case $B$ corresponds to a rupture at $20 \mathrm{~km}(12.4 \mathrm{mi})$ depth, case C corresponds to a rupture at $30 \mathrm{~km}(18.6 \mathrm{mi})$ depth, and case D corresponds to a rupture at 40 $\mathrm{km}(25 \mathrm{mi})$ depth

For each case, we calculate water dynamics in Kachemak Bay (fig. 11). The simulated water levels vary considerably according to different rupture cases because each case results in a distinctly different amount of tectonic subsidence or uplift for Homer and Seldovia. The time series indicate that the rupture at $30 \mathrm{~km}(18.6 \mathrm{mi})$ depth (case C) results in the highest wave amplitude because this case corresponds with the greatest coseismic subsidence during the earthquake. The waves generated by the shallow ruptures of cases $\mathrm{A}$ and $\mathrm{B}$ arrive later than the wave in case $\mathrm{C}$, and also have smaller amplitudes. The deep rupture represented by case $\mathrm{D}$ produces sizable coseismic uplift in the area of Kachemak Bay. As a result, the bay seabed and surrounding land surfaces become relatively higher with respect to post-earthquake sea level and the arriving waves effectively have much smaller amplitudes.

On the basis of these results, we develop hypothetical ruptures with maximum slip in the 20-30 $\mathrm{km}$ (12.4-18.6 mi) depth range (cases B-C). We note that the considered sensitivity cases represent hypothetical $\mathrm{M}_{\mathrm{W}} 8.0$ earthquakes, and that much larger earthquakes are possible in this area (Carver and Plafker, 2008; Shennan, Bruhn, and others, 2014). As in Nicolsky and others (2016), we developed maximum credible scenarios for Homer and Seldovia by assuming a slip up to $35 \mathrm{~m}(115 \mathrm{ft})$ in 


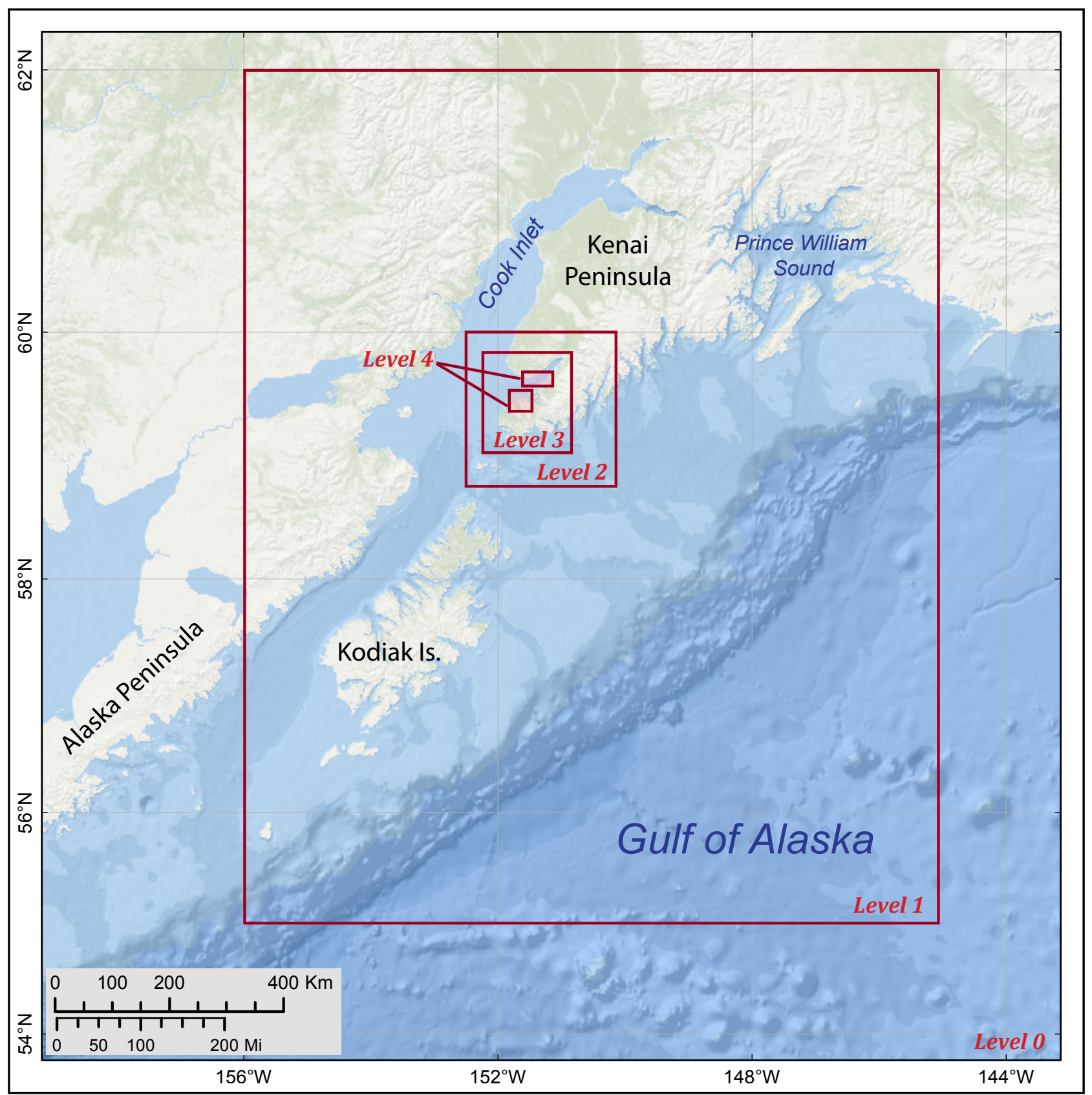

Figure 9A. Nesting of the levels 0-4 bathymetry/topography grids for numerical modeling of tsunami propagation and runup in the Kachemak Bay area. Each embedded grid is outlined by a red rectangle.

the deep and intermediate sections of the AlaskaAleutian megathrust and up to $50 \mathrm{~m}(180 \mathrm{ft})$ in the shallow sections. Maximum slip is assumed along regions of the megathrust that have the capability to generate the highest amplitude waves in Kachemak Bay. We emphasize that the assumed slip distribution is consistent with earthquake source scenarios used by other tsunami modeling studies (for example, Butler, 2014; USGS SAFRR scenario, www2.usgs.gov/natural_hazards/safrr/ projects/tsunamiscenario.asp).

\section{Hypothetical Tectonic Tsunami Sources}

In this section, we describe scenarios for tsunamigenic earthquakes in the Kodiak IslandKenai Peninsula (KI-KP) area of the Aleutian 


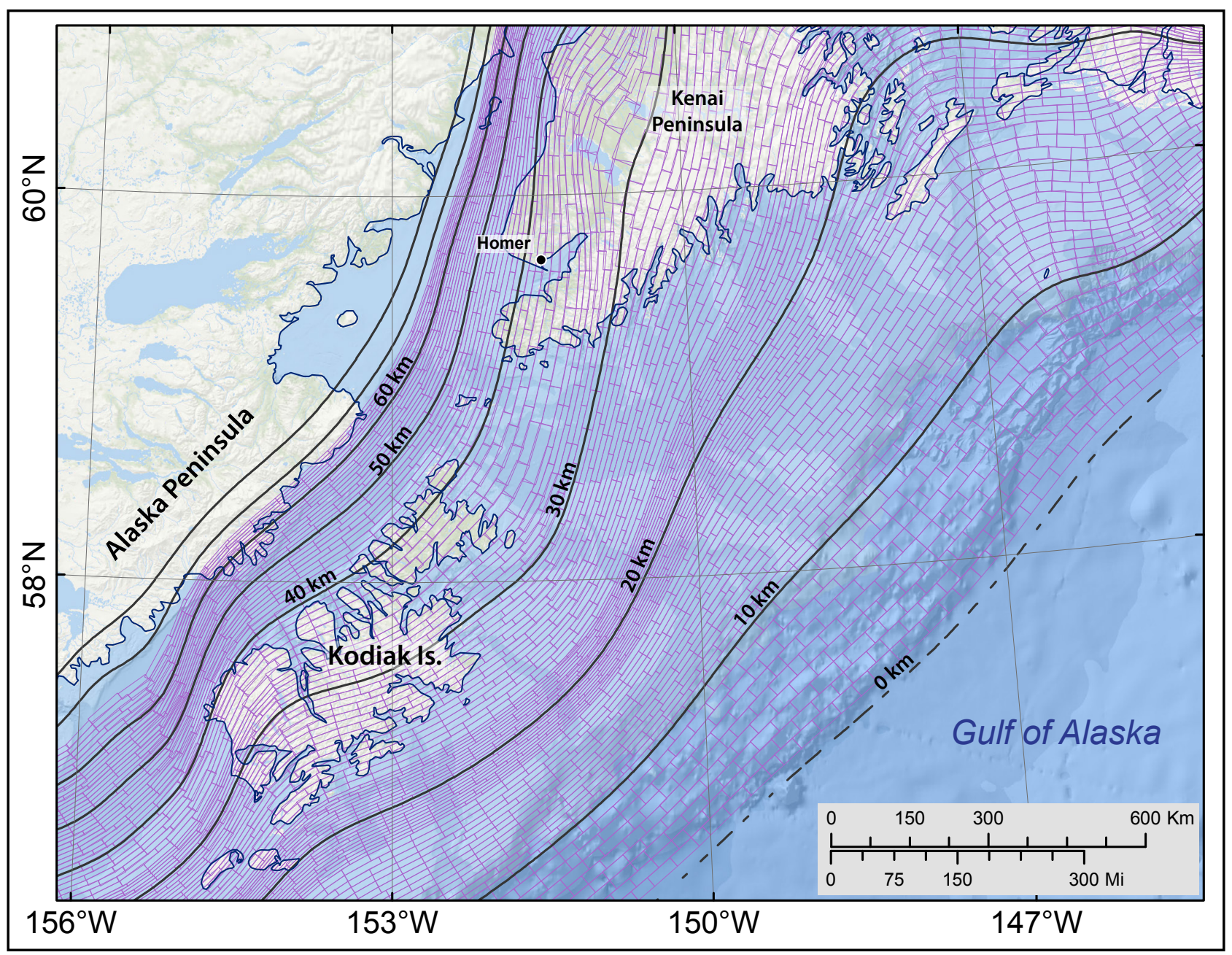

Figure 9B. Discretization of the plate interface used to compute the coseismic vertical displacements with formulae developed by Okada (1985). Black lines mark depth contours (in kilometers) of the plate interface.

megathrust (table 3). Our goal is to determine geologically plausible scenarios that will result in maximum (i.e., worst-case) tsunami inundation in Homer and Seldovia. These scenarios will be called credible worst-case scenarios. Similar to Suleimani and others (2005), we consider a scenario describing the repeat of 1964 earthquake (Scenario 1). However, some new scenarios (2-7) are now based on results of the sensitivity study, geodetic data, and new thoughts regarding local megathrust behavior. Previously, the coseismic slip was limited to $18.5 \mathrm{~m}$ $(60.6 \mathrm{ft})$ near the trench (figure 6 in Suleimani and others, 2005). Now, following modeling results for the USGS SAFRR project and considering implications of the 2011 Tohoku earthquake, we suggest that the maximum slip near the trench could be up to $50 \mathrm{~m}(160 \mathrm{ft})$. Also, for the sake of consistency with previous reports (e.g., Nicolsky and others, 2016, 2017; Suleimani and others, 2016), we consider two earthquakes (scenarios 4 and 7) with slip parameterization according to research by Butler and others (2014).

Figure 12 shows the plate interface in the study area, divided into five regions in the alongstrike direction and into five depth intervals in the downdip direction, for a total of 25 interface segments. We use this mosaic to develop hypothetical ruptures that satisfy different geodetic and geologic constraints. Considerations for selecting or excluding certain segments are outlined below in the description of the scenarios. For each modeled slip distribution on 


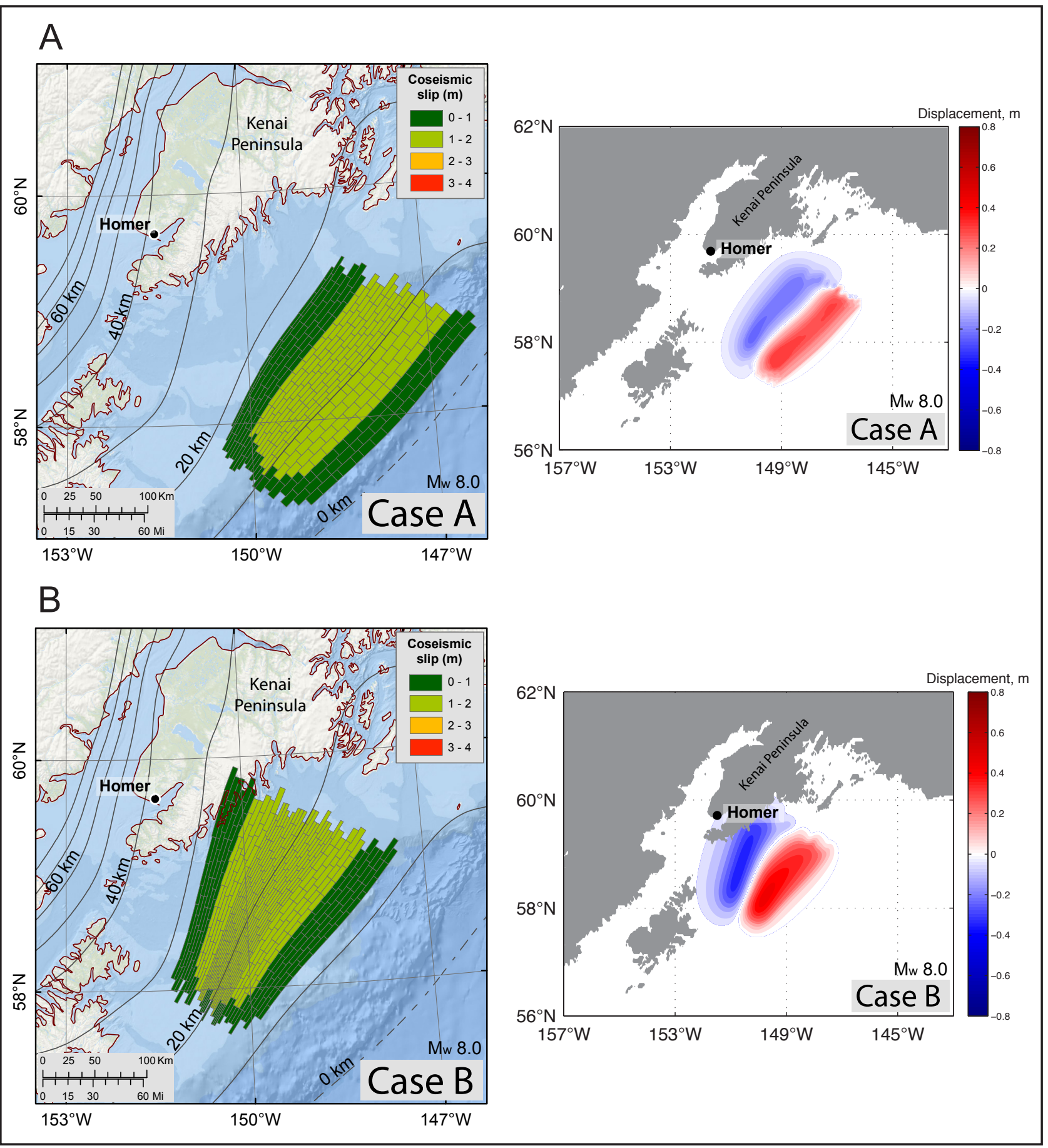

Figure 10A, B. Slip distributions along the plate interface (left column) and computed vertical coseismic deformations (right column) for cases $A$ and $B$, modeling $M_{W} 8.0$ ruptures in the area between Kodiak Island and Kenai Peninsula. The slip location varies in the downdip direction of the plate interface while preserving the same patch configuration. Black lines are depth contours of the subduction interface, in kilometers. Areas of subsidence are shown in blue; areas of uplift are shown in red. 


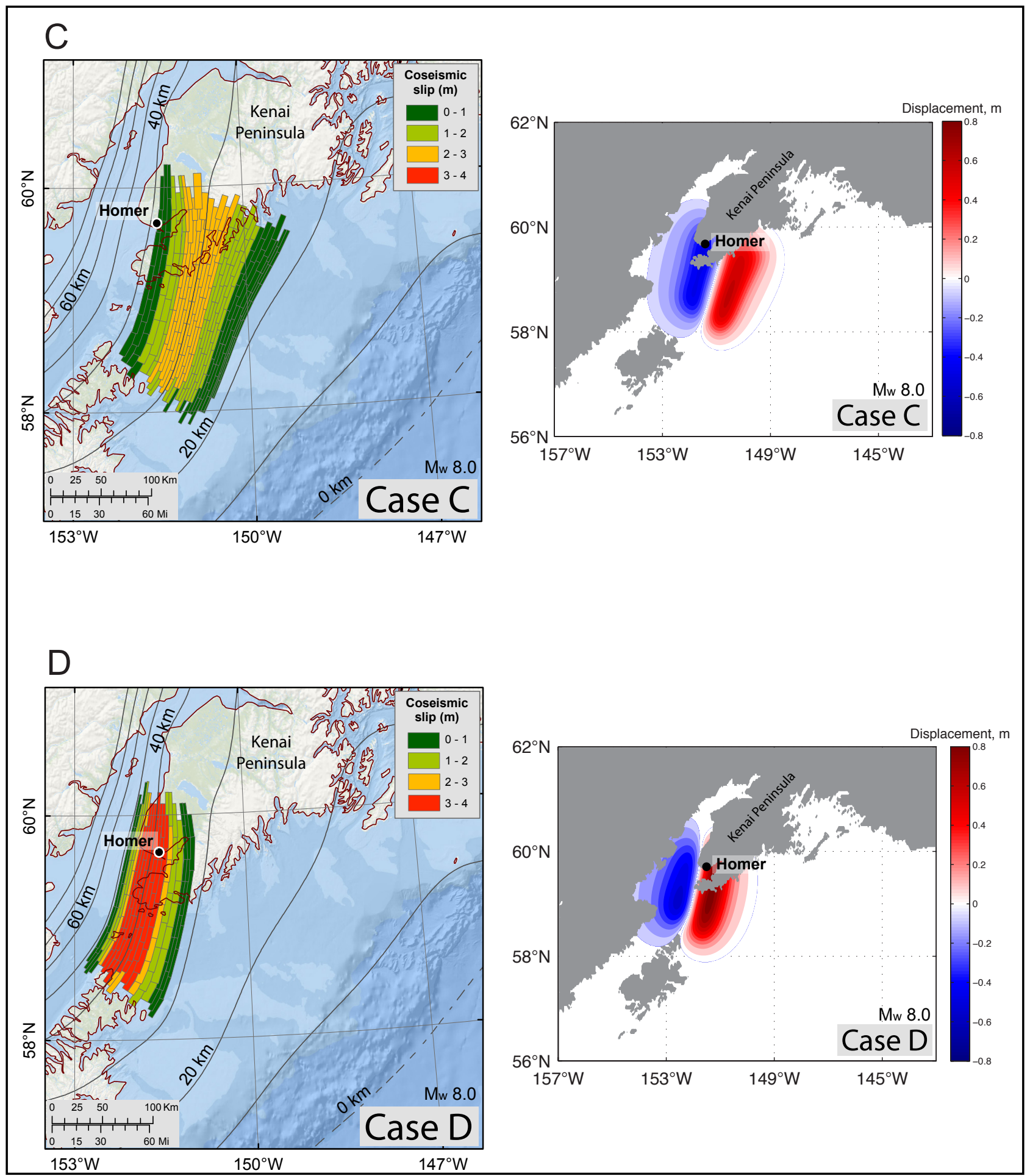

Figure 10C, D. Slip distributions along the plate interface (left column) and computed vertical coseismic deformations (right column) for sensitivity study cases $C$ and $D$, modeling $M_{W} 8.0$ ruptures in the area between Kodiak Island and Kenai Peninsula. The slip location varies in the downdip direction of the plate interface while preserving the same patch configuration. Black lines are depth contours of the subduction interface, in kilometers. Areas of subsidence are shown in blue; areas of uplift are shown in red. 


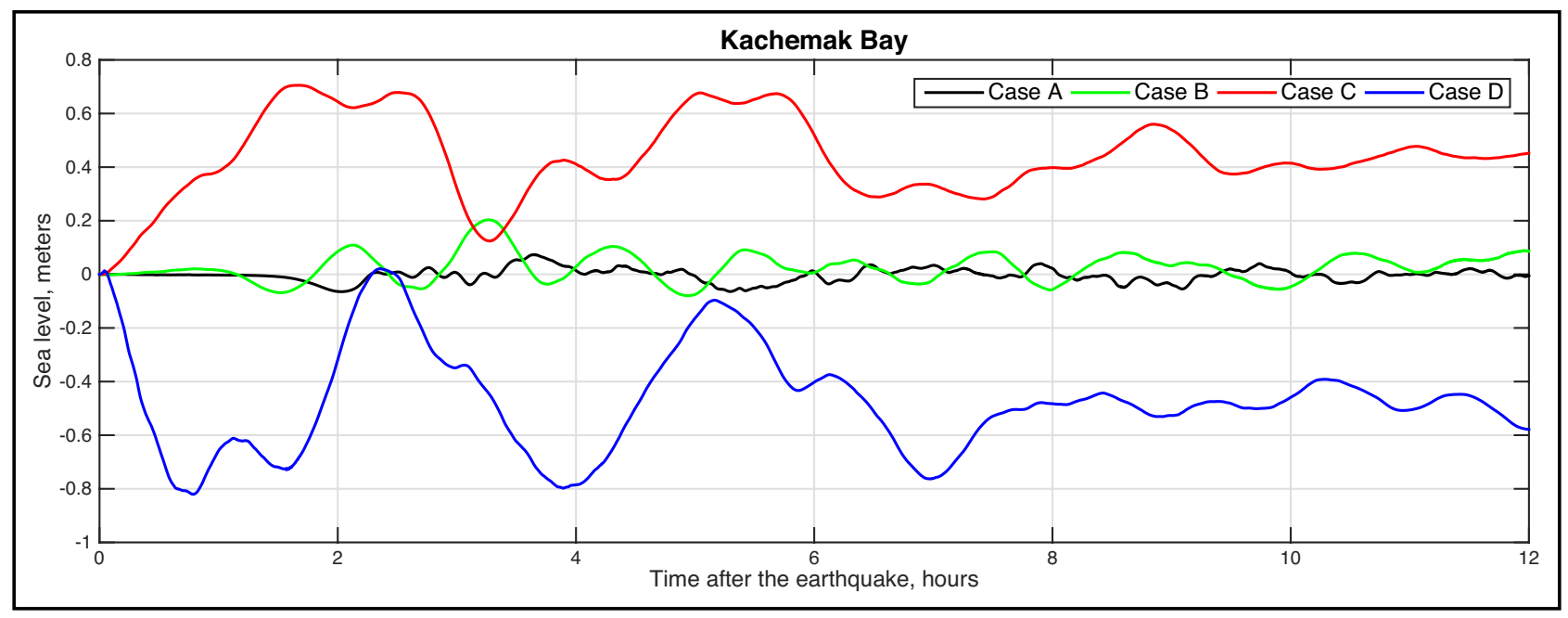

Figure 11. Modeled water-level dynamics in Kachemak Bay for the ground-surface deformations shown in figure 10.

the plate interface, we simulate the impact of the resulting tsunami in Homer and Seldovia. In addition to the repeat of the 1964 earthquake and the near-field hypothetical tsunami sources that are constructed based on the assessment of locked regions and geologic data in the KI-KP area (scenarios 1-7), we include two tsunami sources that have been considered in previous inundation mapping reports and are applicable to the current study: the SAFRR tsunami scenario (Ross and others, 2013) and a rupture of the Cascadia subduction zone.

To construct potential tsunami sources, we use the results of comparison between slip distributions of past great earthquakes and the slip deficit distributions derived from geodetic measurements (Freymueller and others, 2008). Zweck and others (2002) demonstrated good first-order correlation between the two regions of high slip deficit and the two rupture patches of the 1964 earthquake that had high moment release, the PWS and the $\mathrm{KI}$ asperities (fig. 3). At the same time, Zweck and others (2002) found regions of low slip deficit in the area that had low slip in the 1964 earthquake, which is the region that separated the PWS and the KI asperities. This correspondence between the current shallow coupling and the 1964 slip pattern allows them to suggest that the locked regions repeat from one earthquake cycle to another, though not necessarily together as they did in 1964 . The area of low slip corresponds to segments 13,17-19 and 22-24 in figure 13B. Segments 6-10, 11-12 and 14-15 in the green-shaded area correspond to the locked zone derived from plate coupling modeling based on GPS velocities (Zweck and others, 2002). As the GPS data do not constrain the shallow section of the interface corresponding to segments $1-5$, we assume them to be locked for the purpose of constructing credible worst-case scenarios.

There are two major assumptions in comparison of slip deficit models to slip distributions of past earthquakes: (1) the slip deficit distribution is stationary in time; and (2) all interseismic slip deficit is released coseismically. Also, these assumptions are usually applied to along-strike variations, rather than down-dip variations (Freymueller and others, 2008). These research caveats make it impossible to discount scenarios that rupture strongly in areas that showed low slip in 1964. It also makes it impossible to discount scenarios that rupture the shallowest parts of the subduction interface. Finally, we do not account for the finite speed of rupture propagation along the fault, and we assume oceanbottom displacements to be instantaneous.

Table 3 lists all hypothetical tsunami sources evaluated for Homer and Seldovia. The proposed slip distributions for selected scenarios are shown in 
figures 14-19; vertical coseismic deformations for all scenarios are shown in figures 20-28. Below we describe the scenarios, categornized into five groups by specific source characteristics.

Table 3. Hypothetical tectonic scenarios used to model tsunami runup in Homer and Seldovia. Asterisk indicates scenarios have been considered in previous inundation mapping reports.

\begin{tabular}{|c|c|c|c|c|c|c|c|}
\hline Group & $\#$ & $\mathrm{M}_{\mathbf{w}}$ & Description & $\begin{array}{l}\text { Maximum } \\
\text { slip, m (ft) }\end{array}$ & $\begin{array}{l}\text { Average } \\
\text { slip, m (ft) }\end{array}$ & $\begin{array}{c}\text { Maximum } \\
\text { subsidence, } \\
\text { m (ft) }\end{array}$ & $\begin{array}{l}\text { Maximum } \\
\text { uplift, } m(f t)\end{array}$ \\
\hline I & 1 & 9.2 & $\begin{array}{c}\text { Repeat of the } 1964 \text { Great Alaska } \\
\text { Earthquake }\end{array}$ & $23.0(75.0)$ & $10.0(33.0)$ & $5.5(18.0)$ & $9.0(30.0)$ \\
\hline \multirow{2}{*}{ II } & 2 & 9.2 & $\begin{array}{l}\text { Earthquake in the } \mathrm{KI}-\mathrm{KP} \mathrm{P}^{\star} \text { region: } \\
\text { Predominantly shallow slip with } \\
\text { maximum slip at a depth of } 0-10 \mathrm{~km}\end{array}$ & $50.0(164.0)$ & $\begin{array}{l}21.0-25.0 \\
(69.0-82.0)\end{array}$ & $5.4(17.7)$ & 14.2 (46.6) \\
\hline & 3 & 9.3 & $\begin{array}{l}\text { Earthquake in the KI-KP region: } \\
\text { Predominantly shallow slip with } \\
\text { maximum slip at a depth of 5-15 km }\end{array}$ & $50.0(164.0)$ & $\begin{array}{l}22.0-26.0 \\
(72.0-85.0)\end{array}$ & $7.3(24.0)$ & $10.7(35.1)$ \\
\hline \multirow{4}{*}{ III } & 4 & 9.25 & $\begin{array}{l}\text { Earthquake in the KI-KP region } \\
\text { maximum slip at a depth of 5-18 } \\
\text { km and uniform along-strike slip } \\
\text { distribution }\end{array}$ & $50.0(164.0)$ & $36.0(118.0)$ & $6.1(20.0)$ & $22.6(74.1)$ \\
\hline & 5 & 9.3 & $\begin{array}{l}\text { Earthquake in the KI-KP region: } \\
\text { Predominantly shallow slip with } \\
\text { maximum slip at a depth of 5-15 } \\
\text { km and uniform along-strike slip } \\
\text { distribution }\end{array}$ & $45.0(148.0)$ & $\begin{array}{c}19.0-22.0 \\
(62.0-72.0)\end{array}$ & $5.9(19.4)$ & $9.5(31.2)$ \\
\hline & 6 & 9.3 & $\begin{array}{l}\text { Earthquake in the KI-KP region: } \\
\text { maximum slip at a depth of 15-35 } \\
\text { km and uniform along-strike slip } \\
\text { distribution }\end{array}$ & $35.0(115.0)$ & $\begin{array}{c}17.0-18.0 \\
(56.0-59.0)\end{array}$ & $9.0(30.0)$ & $8.9(29.2)$ \\
\hline & 7 & 9.2 & $\begin{array}{c}\text { Earthquake in the KI-KP region with } 35 \\
\mathrm{~m} \text { of maximum slip in the most part of } \\
\text { the rupture and uniform along-strike } \\
\text { slip distribution }\end{array}$ & $35.0(115.0)$ & $28.0(92.0)$ & $7.4(24.3)$ & $14.6(47.9)$ \\
\hline \multirow{2}{*}{ IV } & $8^{*}$ & 9.0 & $\begin{array}{c}\text { Earthquake according to the SAFRR } \\
\text { project }\end{array}$ & $75.0(250.0)$ & $16.0(52.0)$ & $3.0(9.0)$ & $15.0(49.0)$ \\
\hline & 9* & 9.1 & $\begin{array}{c}\text { Earthquake in the Cascadia } \\
\text { subduction zone along the British } \\
\text { Columbia, Washington, Oregon and } \\
\text { northern California shore }\end{array}$ & $45.0(150.0)$ & $36.0(120.0)$ & $8.0(25.0)$ & $11.0(35.0)$ \\
\hline
\end{tabular}




\section{Group I}

Scenario 1. Repeat of the $M_{W}$

9.2 Great Alaska Earthquake.

Vertical coseismic

deformations for this scenario are shown in figure 13.
The previous tsunami hazard assessment by Suleimani and others (2005) used the deformation model of Johnson and others (1996), but after the 2005 publication new deformation models for the 1964 event became available. Therefore we consider the following sub-scenarios for this model:

1A-the 1964 deformation model by Johnson and others (1996);

1B-the 1964 deformation model by Ichinose and others (2007);

1C-the 1964 deformation model by Suito and Freymueller and (2009);

1D-the 1964 deformation model by Suleimani (2011).

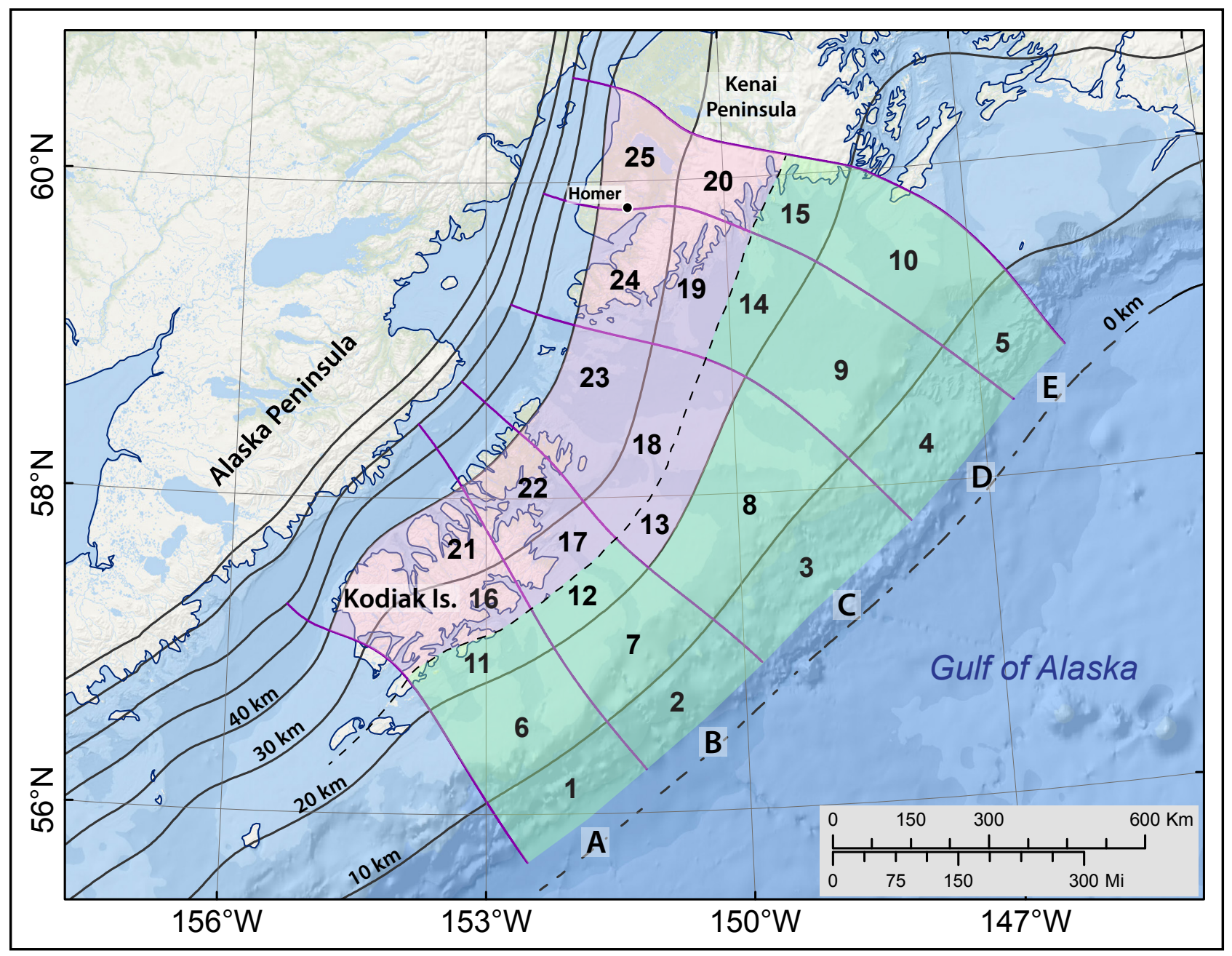

Figure 12. Mosaic of the discretized plate interface used for construction of hypothetical ruptures. Pink shaded area indicate sections that have zero slip in some scenarios due to geodetic constraints. 
Our modeling indicates that the Suleimani (2011) model results in the largest wave heights near Homer and Seldovia. Therefore, following the approach for determining geologically plausible scenarios that will result in maximum tsunami inundation in the communities, we use the coseismic deformation from Suleimani (2011) for the repeat of the 1964 event. Maximum slip is

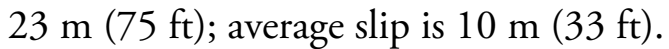

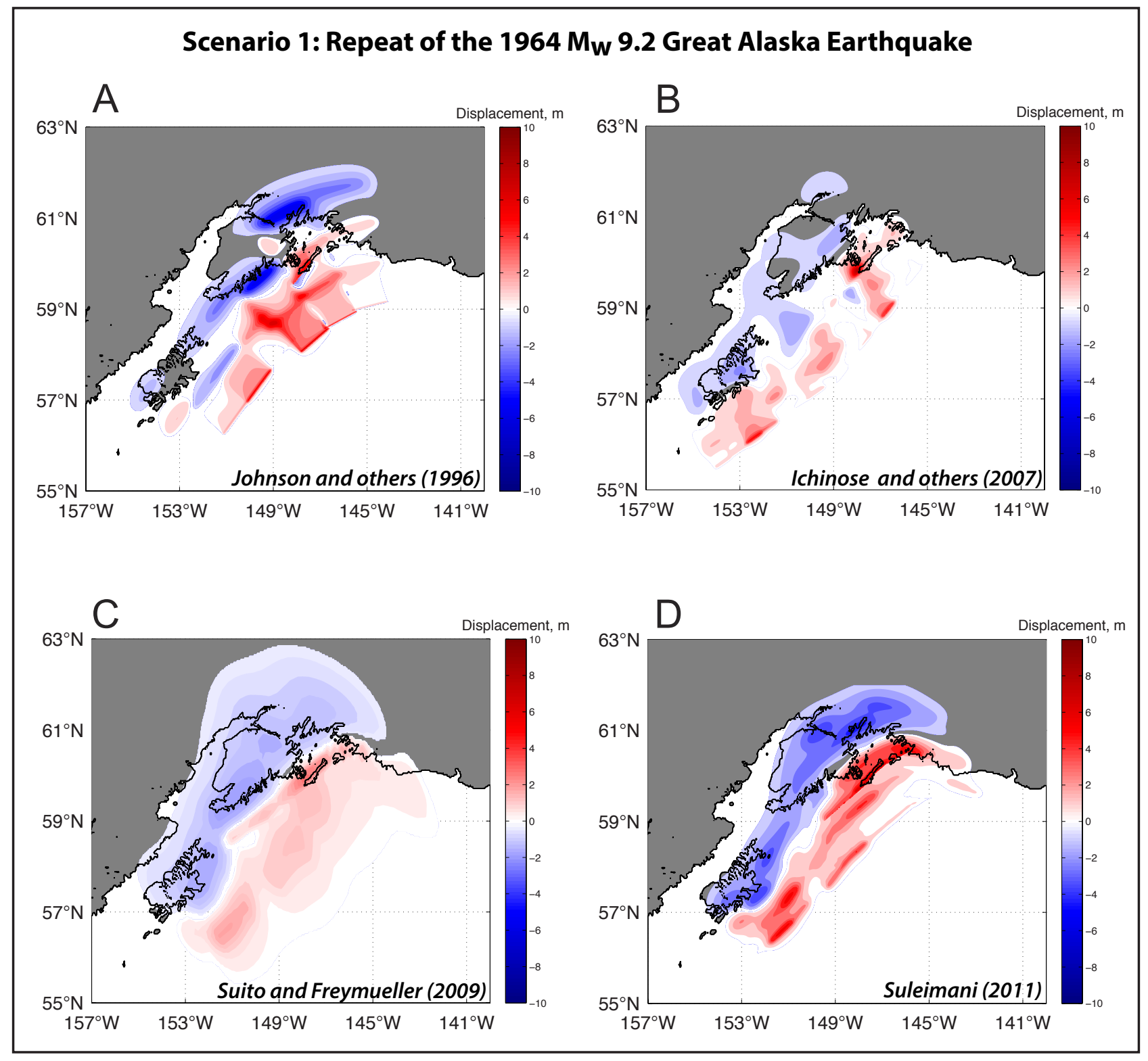

Figure 13. Computed vertical ground-surface deformations for scenario 1, repeat of the $M_{W} 9.2$ Great Alaska Earthquake, representing four different models of the 1964 earthquake. A. The 1964 deformation model by Johnson and others (1996). B. The 1964 deformation model by lchinose and others (2007). C. The 1964 deformation model by Suito and Freymueller (2009). D. The 1964 deformation model by Suleimani (2011). Blue shaded areas are associated with coseismic ground subsidence; areas of uplift are shown in red. 


\section{Group II}

Scenario 2. $M_{W} 9.2$ earthquake in the KI-KP region: Predominantly shallow slip with maximum slip at a depth of $0-10 \mathrm{~km}$ (0-6.2 mi). The proposed slip distributions and vertical coseismic deformations for this scenario are shown in figure 14.

Scenario 3. $M_{W} 9.3$ earthquake in the KI-KP region: Predominantly shallow slip with maximum slip at a depth of 5-15 km (3.1-9.3 mi). The proposed slip distributions and vertical coseismic deformations for this scenario are shown in figure 15.
Zero slip is assigned to segments 13 and 16-25. The scenario consists of KI and PWS asperities, separated by the gap and connected by slip in the shallow part of the rupture. The maximum slip of $50 \mathrm{~m}(164 \mathrm{ft})$ is at a depth of $0-10 \mathrm{~km}(0-6.2$ mi). We consider three sub-scenarios for this model:

2A-maximum slip is distributed uniformly along strike in the shallow part of the rupture;

$2 \mathrm{~B}-$ maximum slip is at the eastern end of the shallow part of the rupture, decreasing toward its western end;

$2 \mathrm{C}$-maximum slip is at the western end of the shallow part of the rupture, decreasing toward its eastern end.

Zero slip is assigned to segments 13 and $16-25$. The source consists of KI and PWS asperities, separated by the gap and connected by slip in the shallow part of the rupture. The maximum slip of $50 \mathrm{~m}(164 \mathrm{ft})$ is at a depth of $5-15 \mathrm{~km}(3.1-9.3$ mi). We consider three sub-scenarios for this model:

3A-maximum slip is distributed uniformly along strike in the shallow part of the rupture;

$3 \mathrm{~B}-$ maximum slip is at the eastern end of the shallow part of the rupture, decreasing toward its western end;

$3 \mathrm{C}$-maximum slip is at the western end of the shallow part of the rupture, decreasing toward its eastern end.
The second group of scenarios incorporate interpretations of current research concerning interseismic slip and rupture patch distribution. We include two earthquake sources (scenarios 2 and 3) in the KI-KP area of the Aleutian megathrust built on these assumptions. These scenarios incorporate inferences made from modern geodetic data about the coupling between the Pacific and North American plates-that certain down-dip regions of the plate interface between Kenai Peninsula and Kodiak Island are steadily slipping during the interseismic period (a.k.a., a "low slip deficit") and are not accumulating elastic strain energy at the same rate as the rest of the plate interface. Therefore, we do not assign slip to these areas (figure 12) in a future rupture scenario. Following lessons learned from the 11 March $2011 \mathrm{M}_{\mathrm{W}} 9.0$ Tohoku earthquake and tsunami (Ito and others, 2011), and given similarities between the Alaska and Tohoku subduction margins (Ryan and others, 2012; Kirby and others, 2013), we propose that a hypothetical rupture might propagate to shallow depths and produce a large amount of slip close to the trench. Therefore, we consider tsunami scenarios with a large amount of slip in the shallow part of the plate interface (segments 1-5), where we allow a maximum slip of $50 \mathrm{~m}(164 \mathrm{ft})$, and we place a maximum slip of $35 \mathrm{~m}(115 \mathrm{ft})$ in other segments. Additionally, we remove 1964 slip from the locked asperities. We take $12 \mathrm{~m}(39 \mathrm{ft})$ of slip from the assumed $35 \mathrm{~m}(115 \mathrm{ft})$ maximum slip deficit on the PWS asperity and assign $23 \mathrm{~m}(75 \mathrm{ft})$ of slip to these segments 9, 10, 14, and 15. Similarly, take $5 \mathrm{~m}$ $(16 \mathrm{ft})$ of slip from the $35 \mathrm{~m}(115 \mathrm{ft})$ maximum slip deficit on the KI asperity and assign $30 \mathrm{~m}$ $(98 \mathrm{ft})$ of slip to segments $6,7,11$, and 12 . The average and maximum slip as well as the rupture areas for scenarios 2 and 3, are set according to the scaling relations of Papazachos and others (2005) and Moss and Travasarou (2006). 


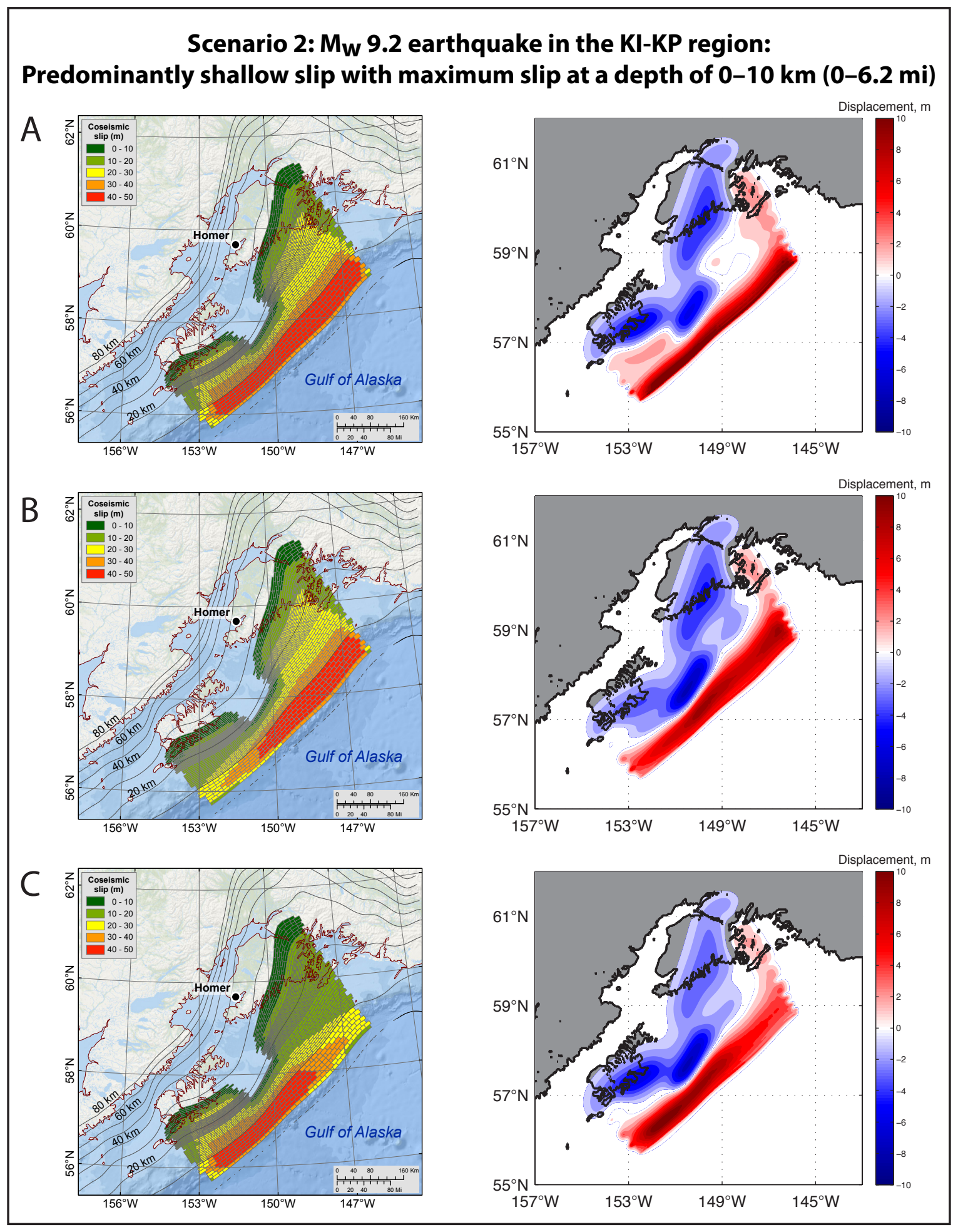

Figure 14. Slip distributions along the plate interface (left column) and computed vertical coseismic deformations (right column) for scenario 2: A M 9.2 earthquake in the KI-KP region; predominantly shallow slip with maximum slip at a depth of $0-10 \mathrm{~km}(0-6.2 \mathrm{mi})$. This scenario consists of the following sub-scenarios. A. Maximum slip is distributed uniformly along strike in the shallow part of the rupture. B. Maximum slip is at the eastern end of the shallow part of the rupture, decreasing toward its western end. C. Maximum slip is at the western end of the shallow part of the rupture, decreasing toward its eastern end. Black lines are depth contours of the subduction interface, in kilometers. Areas of subsidence are shown in blue; areas of uplift are shown in red. 


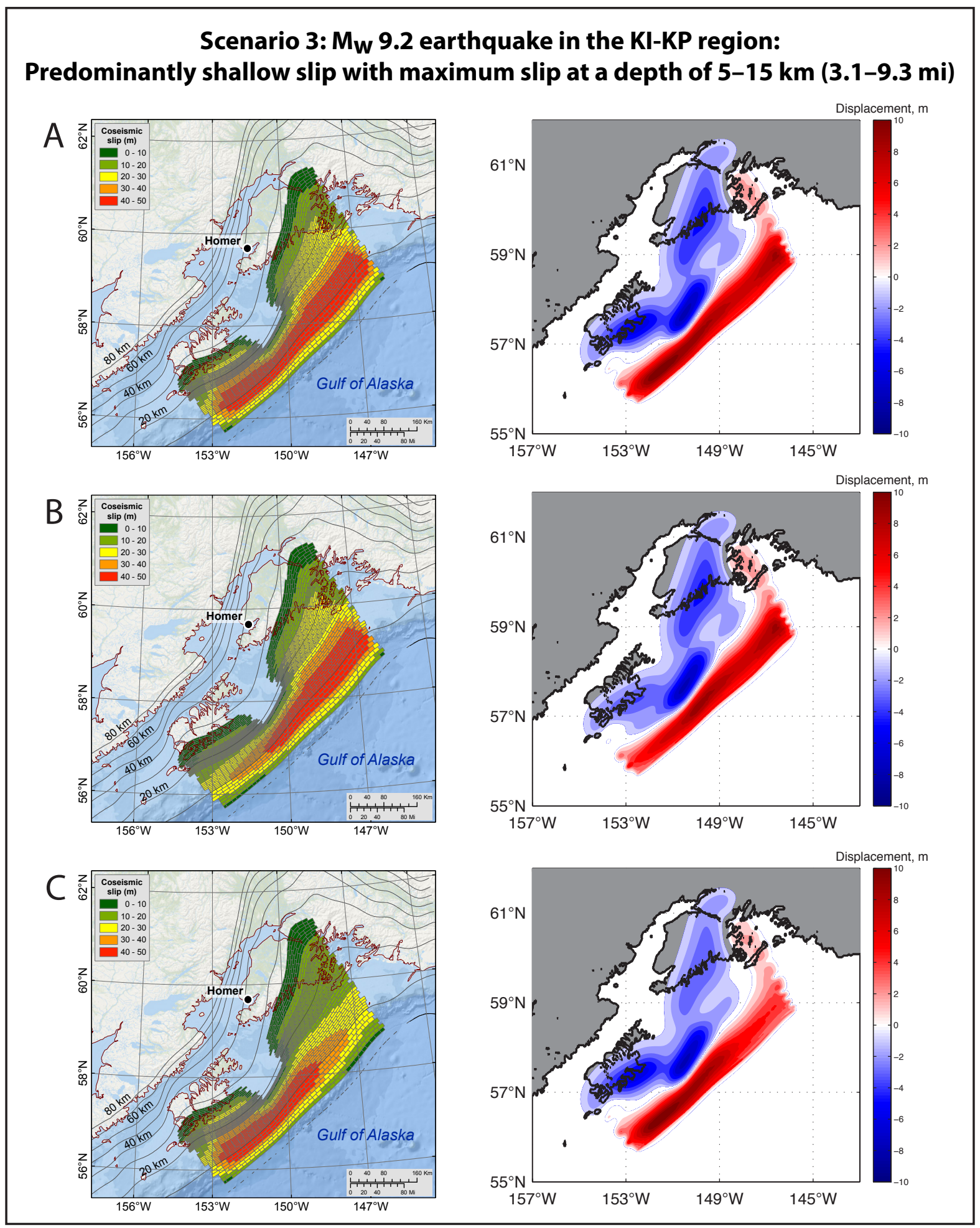

Figure 15. Slip distributions along the plate interface (left column) and computed vertical coseismic deformations (right column) for scenario 3: A $\mathrm{M}_{\mathrm{W}} 9.3$ earthquake in the KI-KP region; predominantly shallow slip with maximum slip at a depth of $5-15 \mathrm{~km}$. This scenario consists of the following sub-scenarios. A. Maximum slip is distributed uniformly along strike in the shallow part of the rupture. B. Maximum slip is at the eastern end of the shallow part of the rupture, decreasing toward its western end. C. Maximum slip is at the western end of the shallow part of the rupture, decreasing toward its eastern end. Black lines are depth contours of the subduction interface, in kilometers. Areas of subsidence are shown in blue; areas of uplift are shown in red. 


\section{Group III}

Scenario 4. $\mathrm{M}_{\mathrm{W}} 9.25$ earthquake in the KI-KP region with $50 \mathrm{~m}$ (164 ft) of maximum slip in the shallow part of the rupture and uniform along-strike slip distribution. The proposed slip distributions and vertical coseismic deformations for this scenario are shown in figure 16.

Scenario 5. $M_{W} 9.3$ earthquake in the KI-KP region: Predominantly shallow slip with maximum slip at a depth of 5-15

$\mathrm{km}$ (3.1-9.3 $\mathrm{mi}$ ) and uniform along-strike slip distribution. The proposed slip distributions and vertical coseismic deformations for this scenario are shown in figure 17.

Scenario 6. $M_{W} 9.3$ earthquake in the $\mathrm{KI}-\mathrm{KP}$ region: maximum slip at a depth of 15-35 km

(9.3-21.7 $\mathrm{mi}$ ) and uniform along-strike slip distribution. The proposed slip distributions and vertical coseismic deformations for this scenario are shown in figure 18.
In this scenario, similar to Butler (2014), we assume $20 \mathrm{~m}$ $(65.6 \mathrm{ft})$ of slip in segments 12-14 and 17-19, and up to 50 $\mathrm{m}(164.0 \mathrm{ft})$ of slip near the trench in segments 2-4 and 7-9. In the rest of the segments the slip is equal to zero. The slip is distributed uniformly along strike. A similar scenario was proposed in the tsunami modeling study for Kodiak (scenario 9 of Suleimani and others, 2017).

All segments have non-zero slip. Maximum slip of $50 \mathrm{~m}$ (164 $\mathrm{ft}$ ) is at a depth of 5-15 km (3.1-9.3 mi), decreasing toward the deeper part of the rupture. We consider three sub-scenarios for this model:

$5 A$-slip is distributed uniformly along strike in the entire rupture area, with the maximum slip in the shallow part of the rupture;

$5 \mathrm{~B}-$ maximum slip is in the shallow part of the rupture, with an additional $35 \mathrm{~m}(115 \mathrm{ft})$ of slip in segment 13;

$5 \mathrm{C}$-maximum slip is in the shallow part of the rupture, with $35 \mathrm{~m}(115 \mathrm{ft})$ of slip in segments 13 and 14 .

All segments have non-zero slip. Maximum slip is assigned to the 15-35 km (9.3-21.7 mi) depth range (per our sensitivity study). We consider four sub-scenarios for this model:

6A-slip is distributed uniformly along strike in the entire rupture. The maximum slip of $35 \mathrm{~m}(115 \mathrm{ft})$ is at a depth of $20 \mathrm{~km}(12.4 \mathrm{mi})$, which corresponds to that of sensitivity case B. The updip and downdip limits of the rupture are $5 \mathrm{~km}(3.1$ $\mathrm{mi})$ and $35 \mathrm{~km}$ (21.7 mi), respectively.

6B-slip is distributed uniformly along strike in the entire rupture, except for the region of maximum slip, where it tapers at both ends of the rupture. The maximum slip of $35 \mathrm{~m}$ (115 $\mathrm{ft})$ is at a depth of $30 \mathrm{~km}(18.6 \mathrm{mi})$, which corresponds to that of sensitivity case $C$. The updip and downdip limits of the rupture are $5 \mathrm{~km}(3.1 \mathrm{mi})$ and $35 \mathrm{~km}(21.7 \mathrm{mi})$, respectively.

6C-slip is distributed uniformly along strike in the entire rupture, except for the region of maximum slip, where it tapers at both ends of the rupture. The down-dip width of the maximum slip zone ( $35 \mathrm{~m}$; $115 \mathrm{ft}$ ) extends from $20-30 \mathrm{~km}$ (12.4-18.6 mi). The updip and downdip limits of the rupture are $5 \mathrm{~km}(3.1 \mathrm{mi})$ and $35 \mathrm{~km}(21.7 \mathrm{mi})$, respectively. 
Scenario 6, continued.

6D-same as scenario 6C plus an additional splay fault with $20 \mathrm{~m}(65 \mathrm{ft})$ of slip. In this scenario, we assume that the slip is partitioned between the megathrust and a splay fault that extends from south of Kenai Peninsula to offshore the easternmost tip of Kodiak Island. Its involvement in the rupture is supported by evidence for slip on the Patton Bay fault system during the 1964 earthquake (Plafker, 1967). Parameters of the splay fault are listed in table 4.

Scenario 7. $M_{W} 9.2$ earthquake in the KI-KP region with $35 \mathrm{~m}(114.8 \mathrm{ft})$ of maximum slip (for almost the entire rupture patch) and uniform along-strike slip distribution. The proposed slip distributions and vertical coseismic deformations for this scenario are shown in figure 19.
In this scenario, similar to Butler (2014), we assume $35 \mathrm{~m}$ $(114.8 \mathrm{ft})$ of slip for nearly the entire rupture patch between the $5 \mathrm{~km}$ (3.1 mi) and $35 \mathrm{~km}$ (21.7 mi) depth contours, with slip decreasing both toward the trench and to the deeper parts of the rupture. Columns $A$ and $E$ in figure 12 have zero slip. Slip is distributed uniformly along strike. A similar scenario was proposed in the tsunami modeling study for Kodiak (scenario 8 of Suleimani and others, 2017).
The third group of scenarios (scenarios 4-7) allow for future ruptures that differ from what was observed in 1964 and that allow rupture in places that may not align with current deformation observations. We include all segments of the plate interface (fig. 12) in a hypothetical rupture and assume that the 1964 earthquake had no effect on their current degree of plate locking or accumulated slip deficit. This approach allows us to determine whether the inclusion of the segments from down-dip regions in seismic moment calculations (and deformation models) will result in significantly higher runup in Homer and Seldovia compared to earthquake source models that are limited by geodetic and geologic data. For the scenarios in the third group, we allow maximum slip of $50 \mathrm{~m}(164 \mathrm{ft})$ in the shallow part (segments 1-5), and maximum slip of $35 \mathrm{~m}$ $(115 \mathrm{ft})$ in other segments. The average and maximum slip as well as the rupture areas for scenarios 4-7 are set according to the scaling relations of Papazachos and others (2005) and Moss and Travasarou (2006).

Recently Butler and others (2014) described a layer of sand discovered in the Makauwahi sinkhole on the island of Kaua'i, Hawai'i. The origin of this layer is attributed to inundation of the sinkhole by a giant paleotsunami following a $\mathrm{M}_{\mathrm{W}} 9+$ earthquake in the eastern Aleutian Islands. Butler (2012) provides an in-depth examination of previous great Aleutian earthquakes and tsunamis impacting Hawai'i. In subsequent research Butler (2014) considered several hypothetical events with $35 \mathrm{~m}$ $(114.8 \mathrm{ft})$ displacement on the megathrust and up to $50 \mathrm{~m}(164.0 \mathrm{ft})$ displacement near the trench. We assume that similar hypothetical events might occur in the KI-KP region.

Table 4. Fault parameters for the splay fault in scenario 6D.

\begin{tabular}{|c|c|c|c|c|c|c|c|c|}
\hline Latitude $\left({ }^{\circ} \mathbf{N}\right)$ & Longitude $\left({ }^{\circ} \mathbf{W}\right)$ & $\begin{array}{c}\text { Depth } \\
(\mathbf{k m})\end{array}$ & $\begin{array}{c}\text { Length } \\
(\mathbf{k m})\end{array}$ & $\begin{array}{c}\text { Width } \\
(\mathbf{k m})\end{array}$ & $\begin{array}{c}\text { Strike } \\
(\mathbf{d e g})\end{array}$ & $\begin{array}{c}\text { Dip } \\
(\mathbf{d e g})\end{array}$ & $\begin{array}{c}\text { Rake } \\
(\mathbf{d e g})\end{array}$ & Slip (m) \\
\hline $57.63596^{\circ} \mathrm{N}$ & $149.36236^{\circ} \mathrm{W}$ & $\begin{array}{c}0.5 \\
(0.3 \mathrm{mi})\end{array}$ & $\begin{array}{c}144.1 \\
(89.5 \mathrm{mi})\end{array}$ & $\begin{array}{c}17 \\
(11 \mathrm{mi})\end{array}$ & 224.6 & 50 & 90 & $\begin{array}{c}20 \\
(66 \mathrm{ft})\end{array}$ \\
\hline
\end{tabular}




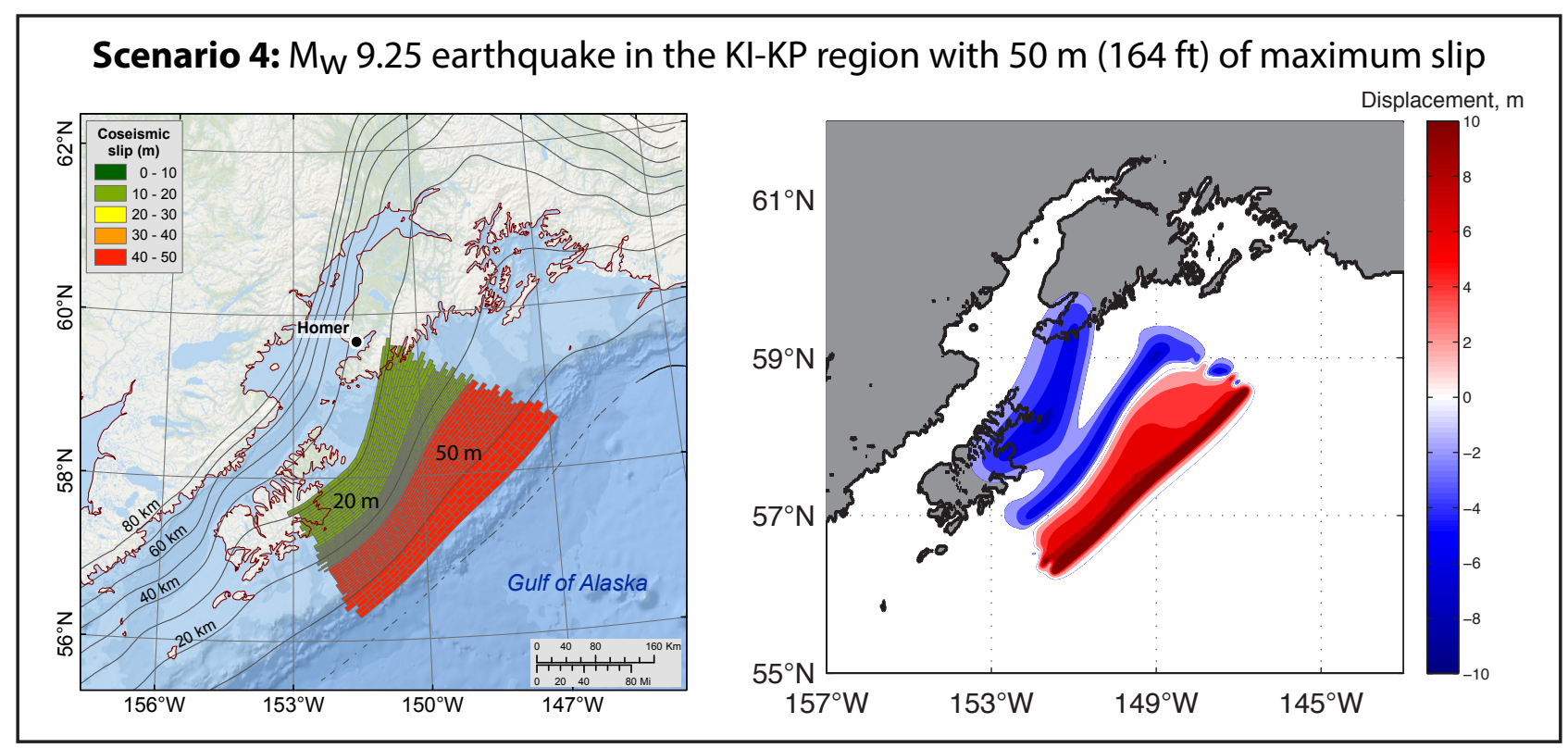

Figure 16. Slip distributions along the plate interface (left) and computed vertical coseismic deformations (right) for scenario 4: A $M_{W} 9.25$ earthquake in the KI-KP region with $50 \mathrm{~m}$ (164 ft) of maximum slip in the shallow part of the rupture and uniform along-strike slip distribution. Black lines are depth contours of the subduction interface, in kilometers. Areas of subsidence are shown in blue; areas of uplift are shown in red.

\section{Group IV}

Scenario 8. $M_{\mathbf{W}} 9.0$ earthquake according to the SAFRR project. Vertical coseismic deformations for this scenario are shown in

figure 20.
This scenario is the same as scenario 5 in Suleimani and others' (2015) tsunami modeling study for Elfin Cove, Gustavus, and Hoonah. Maximum slip is $75 \mathrm{~m}$ (245 ft); average slip is $16 \mathrm{~m}(52 \mathrm{ft})$.
Scenario 9. $\mathrm{M}_{\mathrm{W}} 9.1$ earthquake in the Cascadia subduction zone along the British Columbia, Washington, Oregon, and northern California shores. Vertical coseismic deformations for this scenario are shown in figure 21.
Although a rupture of the Cascadia subduction zone is not a worst-case scenario for the Kachemak Bay area, for the sake of community preparedness we simulate a large hypothetical earthquake along the western seaboard of the U.S. This scenario is the same as scenario 16 in the tsunami modeling studies for King Cove and Cold Bay (Suleimani and others, 2016). Maximum slip is $45 \mathrm{~m}$ (148 ft); average slip is $36 \mathrm{~m}(118 \mathrm{ft})$.
The fourth group of tsunami scenarios includes two tsunami sources that have been considered in previous inundation mapping reports: the USGS SAFRR tsunami scenario (Ross and others, 2013) and rupture of the Cascadia subduction zone. 
Scenario 5: $M_{W} 9.3$ earthquake in the KI-KP region: Predominantly shallow slip with maximum slip at a depth of $5-15 \mathrm{~km}(3.1-9.3 \mathrm{mi})$

A

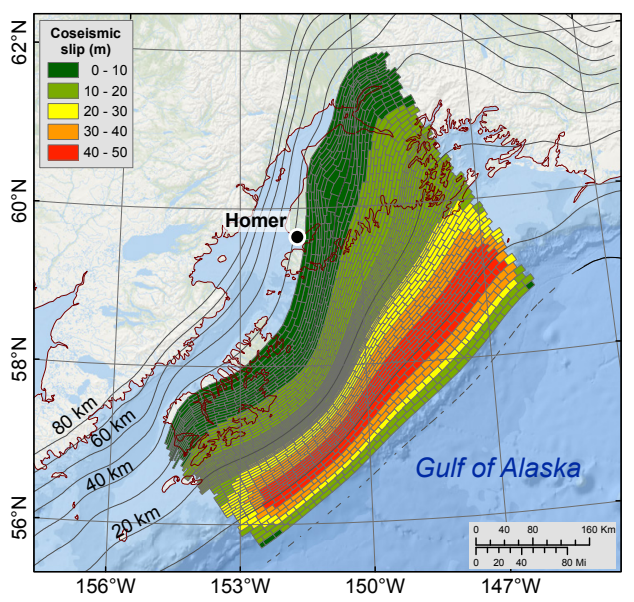

B

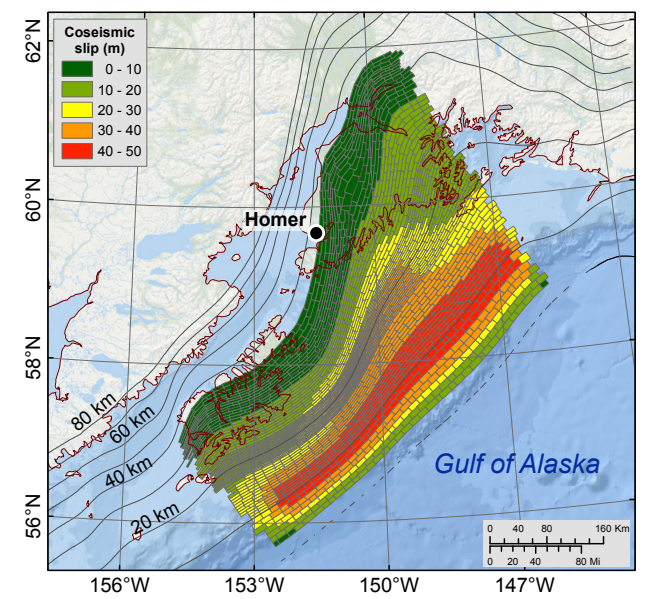

C

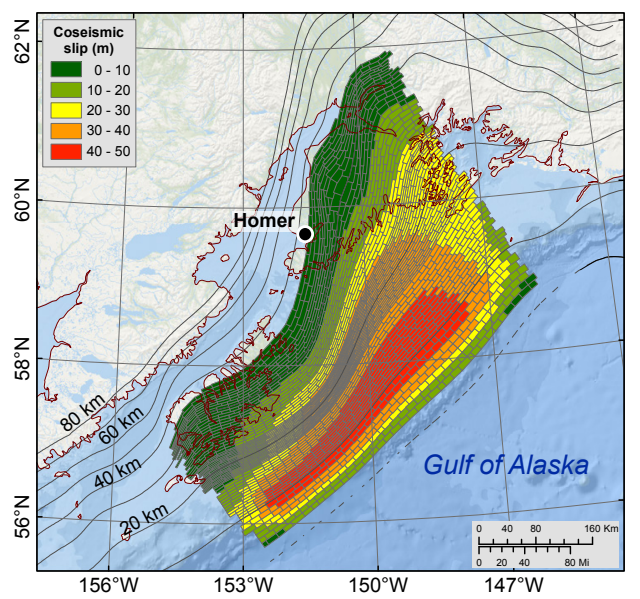

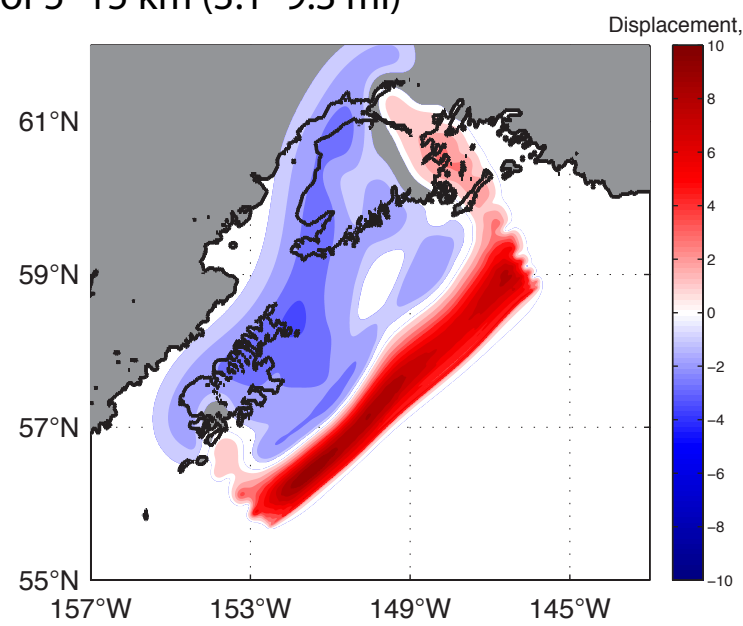
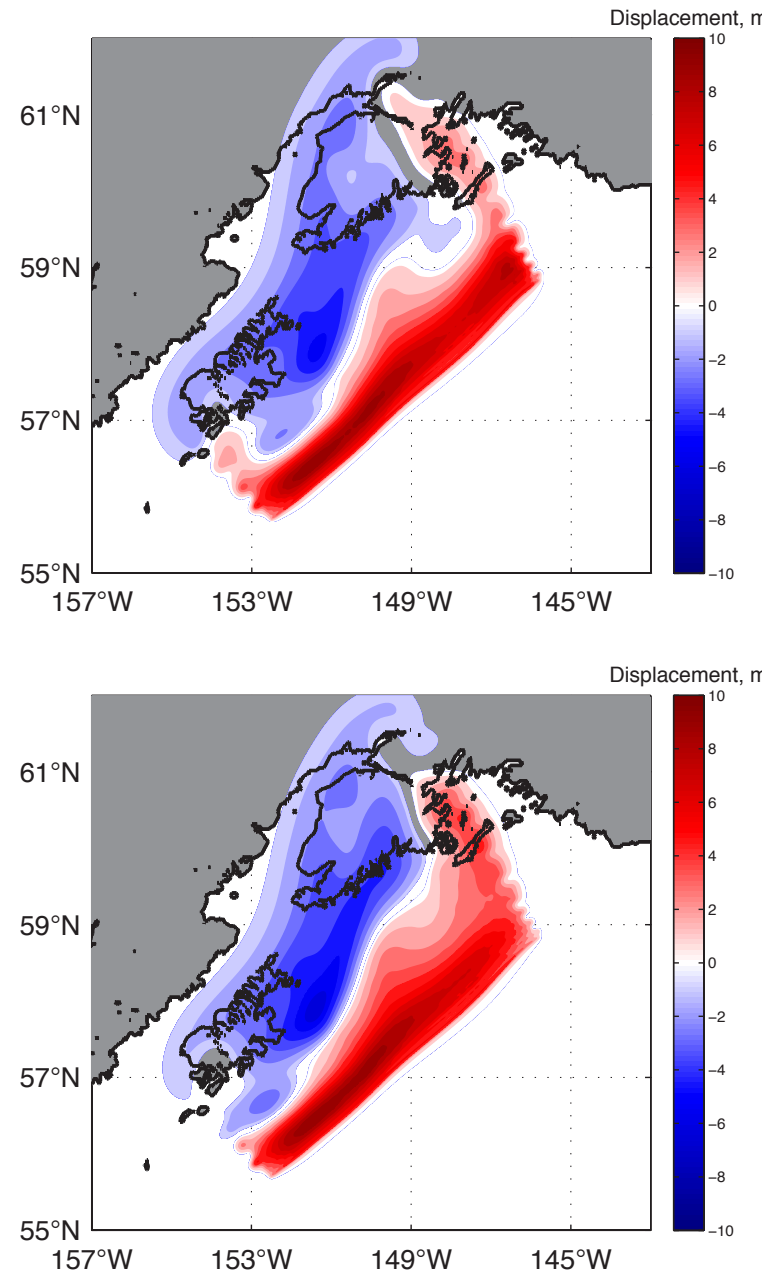

Figure 17. Slip distributions along the plate interface (left column) and computed vertical coseismic deformations (right column) for scenario 5: A $\mathrm{M}_{\mathrm{W}} 9.3$ earthquake in the $\mathrm{KI}-\mathrm{KP}$ region; predominantly shallow slip with maximum slip at a depth of 5-15 km (3.1-9.3 mi). This scenario consists of the following sub-scenarios. A. Slip is distributed uniformly along strike in the entire rupture area with the maximum slip in the shallow part of the rupture. B. Maximum slip is in the shallow part of the rupture, and additional $35 \mathrm{~m}(115 \mathrm{ft}$ ) of slip in segment 13. C. Maximum slip is in the shallow part of the rupture, and $35 \mathrm{~m}(115 \mathrm{ft})$ of slip in segments 13 and 14. Black lines are depth contours of the subduction interface, in kilometers. Areas of subsidence are shown in blue; areas of uplift are shown in red. 
Scenario 6: $\mathrm{M}_{\mathrm{W}} 9.3$ earthquake in the $\mathrm{KI}-\mathrm{KP}$ region:
Maximum slip at a depth of $15-35 \mathrm{~km}(9.3-21.7 \mathrm{mi})$

A

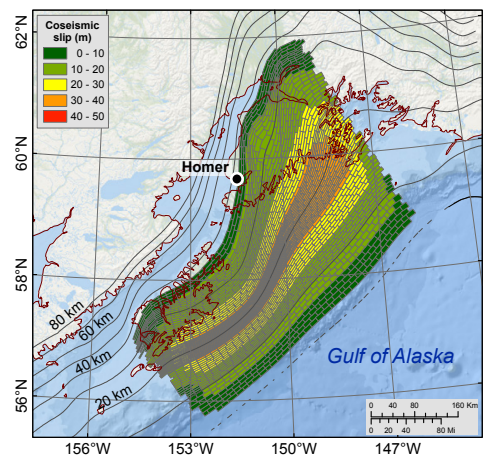

B

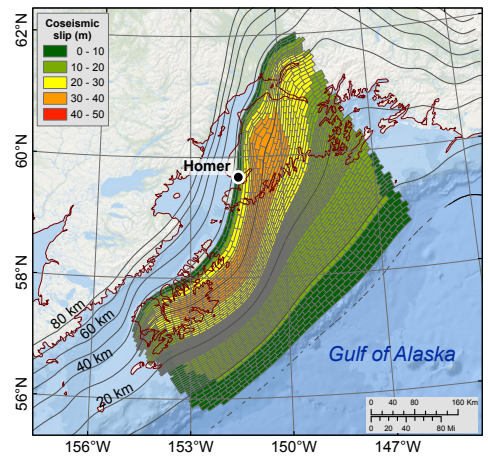

C

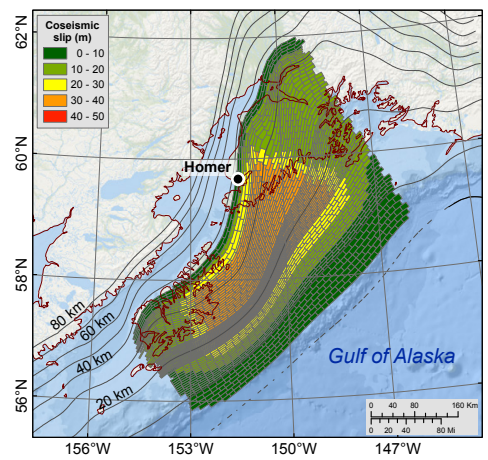

$\mathrm{D}$

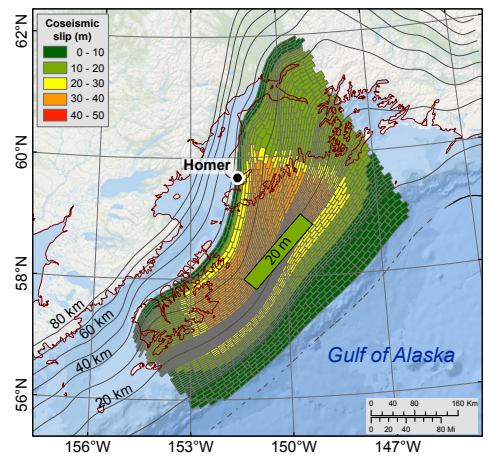

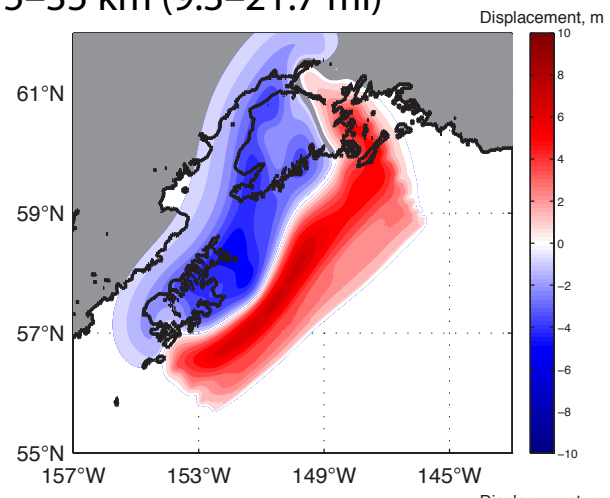
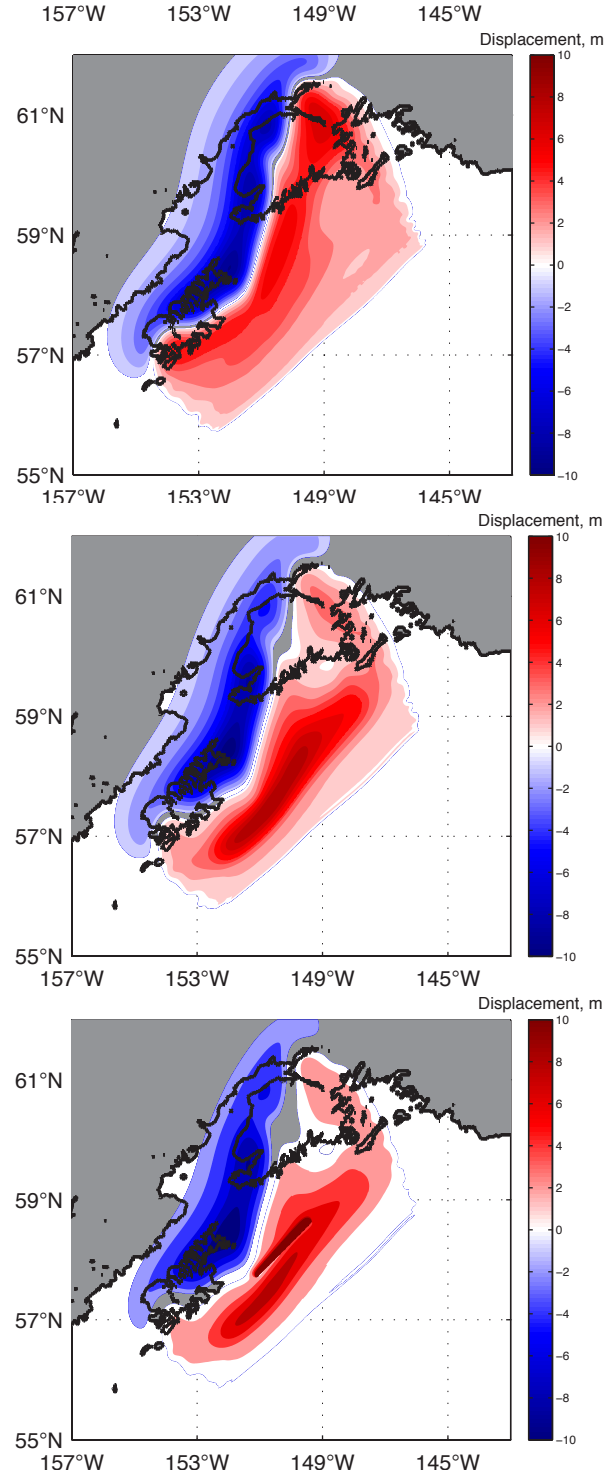

Figure 18. Slip distributions along the plate interface (left column) and computed vertical coseismic deformations (right column) for scenario 6: $\mathrm{A} \mathrm{M}_{\mathrm{W}} 9.3$ earthquake in the KI-KP region; predominantly shallow slip with maximum slip at a depth of 15-35 km (3.1-9.3 mi). This scenario consists of the following sub-scenarios. A. The maximum slip of $35 \mathrm{~m}(115 \mathrm{ft})$ is at a depth of $20 \mathrm{~km}(12.4 \mathrm{mi})$. B. The maximum slip of $35 \mathrm{~m}(115 \mathrm{ft})$ is at a depth of $30 \mathrm{~km}(18.6 \mathrm{mi})$. C. The area of maximum slip of $35 \mathrm{~m}$ (115 ft) extends from 20 to $30 \mathrm{~km}$ (12.4-18.6 mi). D. Same as sub-scenario $C$ plus an additional splay fault. Black lines are depth contours of the subduction interface, in kilometers. Areas of subsidence are shown in blue; areas of uplift are shown in red. 
Scenario 7: $\mathrm{M}_{\mathrm{W}} 9.3$ earthquake in the KI-KP region with $35 \mathrm{~m}(115 \mathrm{ft}$ ) of maximum slip for almost the entire rupture patch
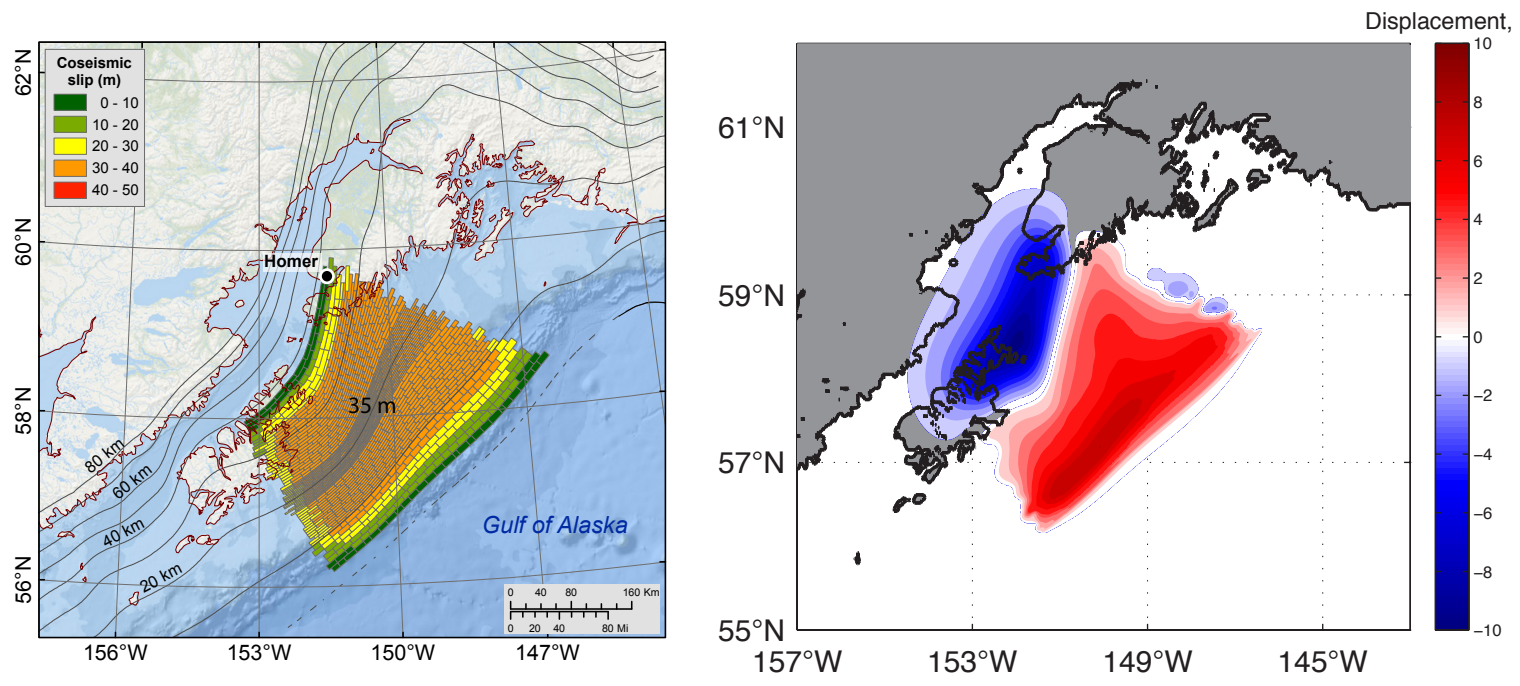

Figure 19. Slip distributions along the plate interface (left) and computed vertical coseismic deformations (right) for

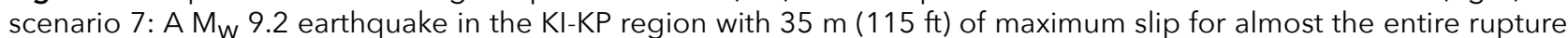
patch (namely between the $5 \mathrm{~km}(3.1 \mathrm{mi})$ and $35 \mathrm{~km}(21.7 \mathrm{mi})$ depth contours) with slip decreasing both toward the trench and to the deeper parts of the rupture. Black lines are depth contours of the subduction interface, in kilometers. Areas of subsidence are shown in blue; areas of uplift are shown in red.

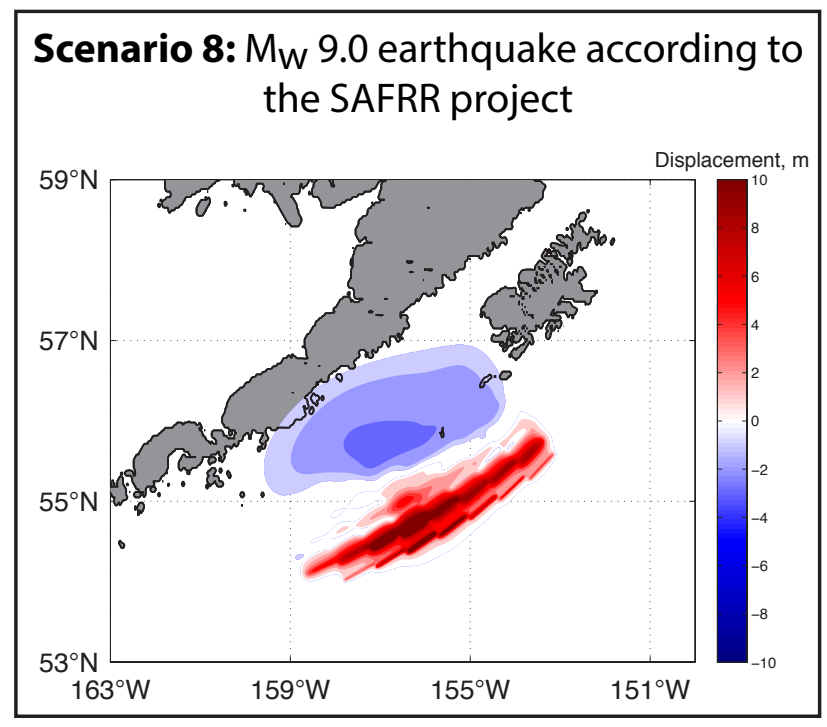

Figure 20, above. Computed vertical coseismic deformations for scenario 8: $\mathrm{M}_{\mathrm{W}} 9.0$ earthquake according to the SAFRR project. Blue shaded areas are associated with coseismic ground subsidence; areas of uplift are shown in red.

Figure 21, right. Computed vertical coseismic deformations for scenario 9: $\mathrm{M}_{\mathrm{W}} 9.1$ earthquake in the Cascadia subduction zone along the British Columbia, Washington, Oregon, and northern California shores. Blue shaded areas are associated with coseismic ground subsidence; areas of uplift are shown in red.
Scenario 9: $M_{W} 9.1$ earthquake in the Cascadia subduction zone along the British Columbia, Washington, Oregon and northern California shores

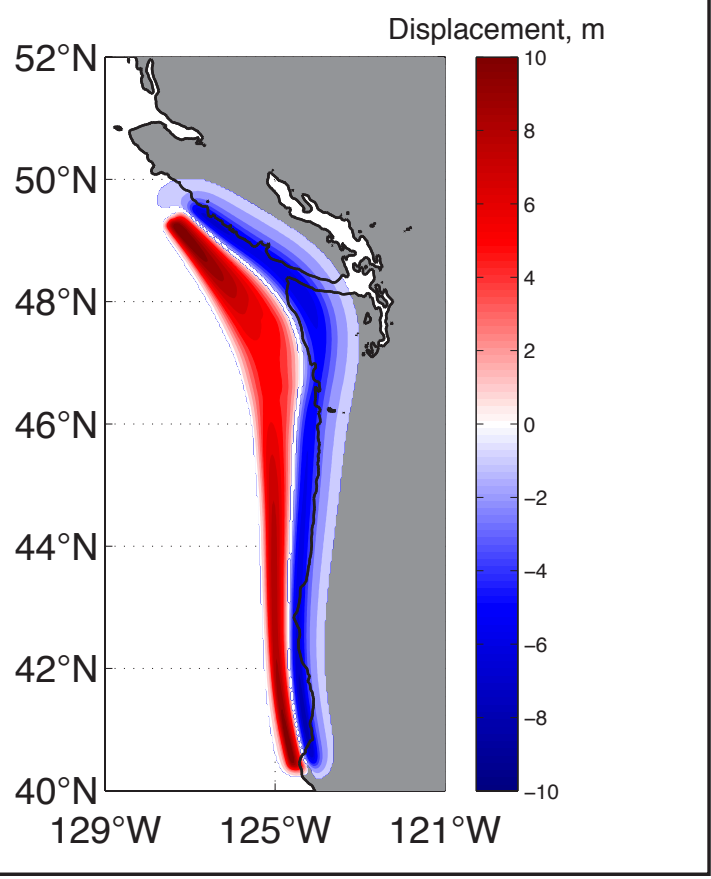




\section{Hypothetical Landslide Tsunami Sources}

In addition to hypothetical tectonic scenarios, we consider several submarine landslide scenarios that could generate hazardous waves in Kachemak Bay. Subaerial landslides are not considered because of the significant uncertainty associated with specifying their potential locations and volumes. The exclusion of subaerial landslides is a significant caveat that is worth noting by anyone using the results of this report.

Overviews of submarine landslides in waters close to Alaska are presented by Schwab and others (1993), Kulikov and others (1998), and Lee and others (2006). Additionally, Lemke (1967), Wilson and Tørum (1968), Plafker and others (1969), and Shannon and Hilts (1973) conducted geologic investigations after the 1964 earthquake in numerous locations around south-central and southeastern Alaska. One of the resounding conclusions from these studies is that accumulation of loose sediment or artificial fill material on underwater slopes can cause over-steepening of walls and contributes directly to underwater slope instability. During an earthquake, dynamic forces imposed by seismic acceleration add to the gravitational force and trigger sliding of the unconsolidated sediments (Hampton and others, 2002). The major factors contributing to total slide volume and extent are thought to be the intensity and duration of ground motion, configuration of underwater slopes, load of the material (including natural and artificial fill, docks, etc.) above water level, and type of sediment forming these slopesunconsolidated or fine-grained materials are more prone to failure. Therefore, areas with high sedimentation rates, artificial fill areas, and glacial creek deltas are especially susceptible to sliding and are considered as locations for potential landslides (Nicolsky, Suleimani, Combellick, and Hansen, 2011; Nicolsky and others, 2011a, 2013; Suleimani and others, 2010, 2015, 2016). During the 1964 earthquake, submarine slides occurred at multiple locations in southcentral Alaska. For example, the total volume of transported material in Resurrection Bay, where Seward is located, was estimated by to be 210 million $\mathrm{m}^{3}\left(270\right.$ million $\left.\mathrm{yd}^{3}\right)$ for 10 different slides, the thickest of which was about $60 \mathrm{~m}$ (200 ft). Interestingly, several ground failures occurred in the middle of Resurrection Bay at significant water depths (Haeussler and others, 2007); as a result of the 1964 earthquake, the mid-bay channel in Resurrection Bay was deepened by $25 \mathrm{~m}$ (82 ft). Furthermore, in a recent study, Brothers and others (2016) indicate that a large submarine landslide near the village of Chenega removed $20-50 \mathrm{~m}(20-160 \mathrm{ft})$ of sediment at depths of 120-360 m (400-1,200 ft). These two studies indicate that large submarine landslides can occur not only in close proximity to active sources of sedimentation (i.e., present-day river deltas), but also in locations where sediments were deposited in the past.

Because there is no geotechnical data for submarine sediments, we take a heuristic approach to developing a set of hypothetical landslide scenarios. First, we identify locations of previous landslides, creek deltas, and artificial fill areas near the community. Next, we assume generic, bowlshaped failure surfaces in the ground material at the identified locations based on the generic parameters of landslides investigated after the 1964 earthquake (Nicolsky and others, 2013; Suleimani and others, 2015, 2016). Lastly, we differentiate between the modern bathymetry and failure surfaces to compute the thicknesses of potentials slides and calculate their volumes (Nicolsky and others, 2013, 2017; Suleimani and others, 2015, 2016).

Using bathymetric contours for Kachemak Bay, we estimate that the depth of the landslide scar near the distal end of the Homer spit is about 5-10 m (16-33 ft) (fig. 7A). Unfortunately, the total volume and geometry of the landslides near Homer remain unknown but ground failures along the fjord walls of Resurrection Bay near Seward are better studied (e.g., Lemke, 1967; Haeussler and others, 2007). Given the lack of geotechnical data for submarine sediments, we try to limit thickness of hypothetical slides at the distal end of the 
spit to $30 \mathrm{~m}(100 \mathrm{ft})$, which is about three to five times larger than the calculated depth of the scars near the spit. Because slide volume is an important parameter for the tsunami generation potential, we consider a sensitivity study with respect to this value later in the report.

On the opposite side of Kachemak Bay, next to Wosnesenski River and Grewingk Creek, we limit thicknesses of hypothetical slides to 50-90 $\mathrm{m}$ (160-230 ft). The latter values are in line with reconstruction of landslide thicknesses for the historic events. For example, in Whittier, the maximum slide thickness at the creek delta was about 50-70 m (160-230 ft) (Kachadoorian, 1965, plate 3). Larger landslides occurred in Valdez. Coulter and Migliaccio (1966, plate 2) estimated that approximately 75 million $\mathrm{m}^{3}$ (98 million $\mathrm{yd}^{3}$ ) of unconsolidated deposits were transferred from the Valdez waterfront into the bay, and the waterfront slide thickness was estimated at $<100 \mathrm{~m}(<330 \mathrm{ft})$.

We identified three potential slide areas in the vicinity of Homer: around the distal end of the spit and along two submarine river deltas. A landmass failure at shallow depth has much greater potential to produce a tsunami than the fjord-bottom material. Therefore, we place landslides near the shore in shallow water to increase their wave generation potential. Slide volumes and maximum slide thicknesses for each scenario are summarized in table 5 .

Modeling of waves generated by subaerial slides and rockfalls presents a major challenge. Subaerial landslides, unlike submarine ones, impact water bodies at high speeds and can cause larger tsunamis, given all other assumptions are the same. The impact of a rockfall on the water surface results in a turbulent splash and consequent mixing of the granular materials with water. Unfortunately, coupling NHWAVE to the depth-integrated layer of Newtonian viscous fluid for the landslide model is not an optimal modeling approach to rockfalls or subaerial slides. Furthermore, due to insufficient data on the locations and volumes of hypothetical subaerial landslides, we do not model tsunamis generated by this type of landslide in this report.

Table 5. Hypothetical landslide scenarios used to model potential extent of inundation by landslide-generated tsunamis (fig. 22).

\begin{tabular}{|c|c|c|c|}
\hline Scenario & $\begin{array}{c}\text { Location of } \\
\text { Underwater Slide }\end{array}$ & $\begin{array}{c}\text { Maximum Slide } \\
\text { Volume, Million } \mathrm{m}^{3}\left(\mathrm{yd}^{3}\right)\end{array}$ & $\begin{array}{l}\text { Maximum Slide } \\
\text { Thickness, } m \text { (ft) }\end{array}$ \\
\hline 10 & $\begin{array}{l}\text { Cook Inlet side } \\
\text { of Homer Spit }\end{array}$ & $56(73)$ & $32(105)$ \\
\hline 11 & Tip of the Homer Spit & $19(25)$ & $18(59)$ \\
\hline 12 & $\begin{array}{c}\text { Kachemak Bay } \\
\text { side of Homer Spit }\end{array}$ & $75(98)$ & $34(110)$ \\
\hline 13 & $\begin{array}{c}\text { Offshore of } \\
\text { Wosnesenski River delta }\end{array}$ & $22(29)$ & $58(190)$ \\
\hline 14 & $\begin{array}{l}\text { Offshore of Grewingk } \\
\text { Creek delta }\end{array}$ & $29(38)$ & $30(98)$ \\
\hline
\end{tabular}




\section{Hypothetical Landslide Scenarios for the City of Homer:}

\author{
Scenario 10. An underwater \\ slide offshore of the Cook \\ Inlet side of Homer spit \\ (Cl slide, fig. 22a).
}

Homer Spit is a remnant of a terminal-moraine complex formed during glaciation about 16,000 years ago (Karlstrom, 1964; Reger and others, 2007, fig. 8). The Archimandritof Shoals, located just southwest of the spit, is also associated with the moraine and is linked to a deposition area of subglacial river emerging from beneath the glacier. Currently, coastal erosion and deposition are responsible for shaping the spit. Both the spit and shoals are largely composed of medium gravel, interlaced with some sand (Stanley, 1966).

During the 1964 Great Alaska Earthquake, the spit experienced differential subsidence and local landsliding (fig. 6). Examination of the bathymetry (figure 7A) also reveals signs of mass wasting along the slope of Archimandritof Shoals. Thus, a ground failure in this area could generate waves directed toward the southern shore of Cook Inlet. However, the secondary wave, also called the rebound wave, can propagate north towards the spit. After specifying hypothetical failure surfaces for the $\mathrm{Cl}$ slide, we simulate a slide volume of 56 million $\mathrm{m}^{3}$ (73 million $\left.\mathrm{yd}^{3}\right)$, with maximum thickness of $32 \mathrm{~m}$ (105 ft).

The $\mathrm{Cl}$ slide thickness is three to five times greater than the depth of submarine scars in the area. Together with slide density, slide thickness is one of the governing parameters determining size of landslide-generated waves. However, unlike the slide density, we are less certain about the thickness of hypothetical slides. Therefore, we enhance this scenario by considering a thicker slide, as the volume determines how much water is displaced by the sliding mass. We increase the volume of the Cook Inlet slide in scenario 10 by about 50 percent to be 84 million $\mathrm{m}^{3}$ (276 million $\mathrm{yd}^{3}$ ), while all other model parameters are held constant.

An area around the distal end of Homer Spit was the location of a ground failure in the 1964 Great Alaska Earthquake and may be prone to additional ground failures. Here, we develop a scenario describing a collapse of residual ground material around the tip of the spit. Although the primary wave is going to be directed away from the spit, the rebound wave could produce local runup. After specifying hypothetical failure surfaces for the TS slide, we simulate a slide volume of 19 million $\mathrm{m}^{3}$ (25 million $\mathrm{yd}^{3}$ ), with maximum thickness of $18 \mathrm{~m}(59 \mathrm{ft})$. 


\author{
Scenario 12. An underwater \\ slide offshore of the \\ Kachemak Bay side of Homer \\ Spit (KB slide, fig. 22c).
}

Scenario 13. An underwater slide at the mouth of the Wosnesenski River (WR slide, fig. 22d).

\section{Scenario 14. An underwater slide at the mouth of the Grewingk Creek (GC slide,}

fig. 22e).
During the 1964 Great Alaska Earthquake, ground failures occurred offshore of the Kachemak Bay side of the Homer Spit and caused a collapse of the breakwaters in the ocean (fig. 6). Similar to the $\mathrm{Cl}$ and TS slides, a potential submarine landslide offshore of the Kachemak Bay side of the spit can generate a rebound wave threatening the spit. After specifying hypothetical failure surfaces for the KB slide, we simulate a slide volume of 75 million $\mathrm{m}^{3}$ (98 million $\mathrm{yd}^{3}$ ), with maximum thickness of $34 \mathrm{~m}$ (110 ft).

Before discharging into the ocean, the Wosnesenski River forms an extensive delta along the southern shore of Cook Inlet. Similar to the Lowe River in Valdez and Resurrection River in Seward, the deltas of which were locations of submarine landslides in 1964, the Wosnesenski River is a carrier of glacial sediments into the fjord.

After reviewing the bathymetry offshore the Wosnesenski River delta, we hypothesize that some slumping previously occurred in this area. Therefore, we assume that sediment along the steep slopes can fail and generate waves directed towards Homer Spit. After specifying hypothetical failure surfaces for the WR slide, we simulate a slide volume of 22 million $\mathrm{m}^{3}$ (29 million $\left.\mathrm{yd}^{3}\right)$, with maximum thickness of $58 \mathrm{~m}$ (190ft).

The Grewingk Glacier originating in the Kenai Range forms an extensive outwash plain and a semicircular alluvial fan protruding far offshore into Kachemak Bay. Accumulation of sediment at the distal end of the fan creates a potential for submarine landslides. Waves generated at the segment south of Grewingk Creek will be directed toward the community of Homer. After specifying hypothetical failure surfaces for the GC slide, we simulate a slide volume of 29 million $\mathrm{m}^{3}$ (38 million $\mathrm{yd}^{3}$ ), with maximum thickness of $30 \mathrm{~m}$ (98 ft).

\section{MODELING RESULTS}

We performed numerical calculations for each of the 14 hypothetical earthquake and landslide scenarios described above and summarized in tables 3 and 5. Water dynamics are modeled for each grid listed in table 2; the extent of inundation and flow depths are calculated only for the level 4 high-resolution grids. For each of the tectonic scenarios that consist of sub-scenarios, we selected for our analysis a sub-scenario that resulted in the greatest tsunami heights and largest inundation zones in Homer and Seldovia. These are sub-scenarios $1 d, 2 a, 3 a, 5 c$ and $6 c$. To simplify the report going forward, we will drop the letter from each sub-scenario and refer to the scenario by number only (we will refer to sub-scenario $1 \mathrm{~d}$ as scenario 1 , sub-scenario $2 \mathrm{a}$ as scenario 2 , and so on).

Map sheets 1-3 show the maximum composite extent of inundation for all scenarios, and the maximum composite flow depths over dry land. The composite values are calculated as follows: for each tsunami scenario, the tsunami flow depth is computed at each grid point and at every time step during the tsunami propagation time, and the maximum value is kept; then 


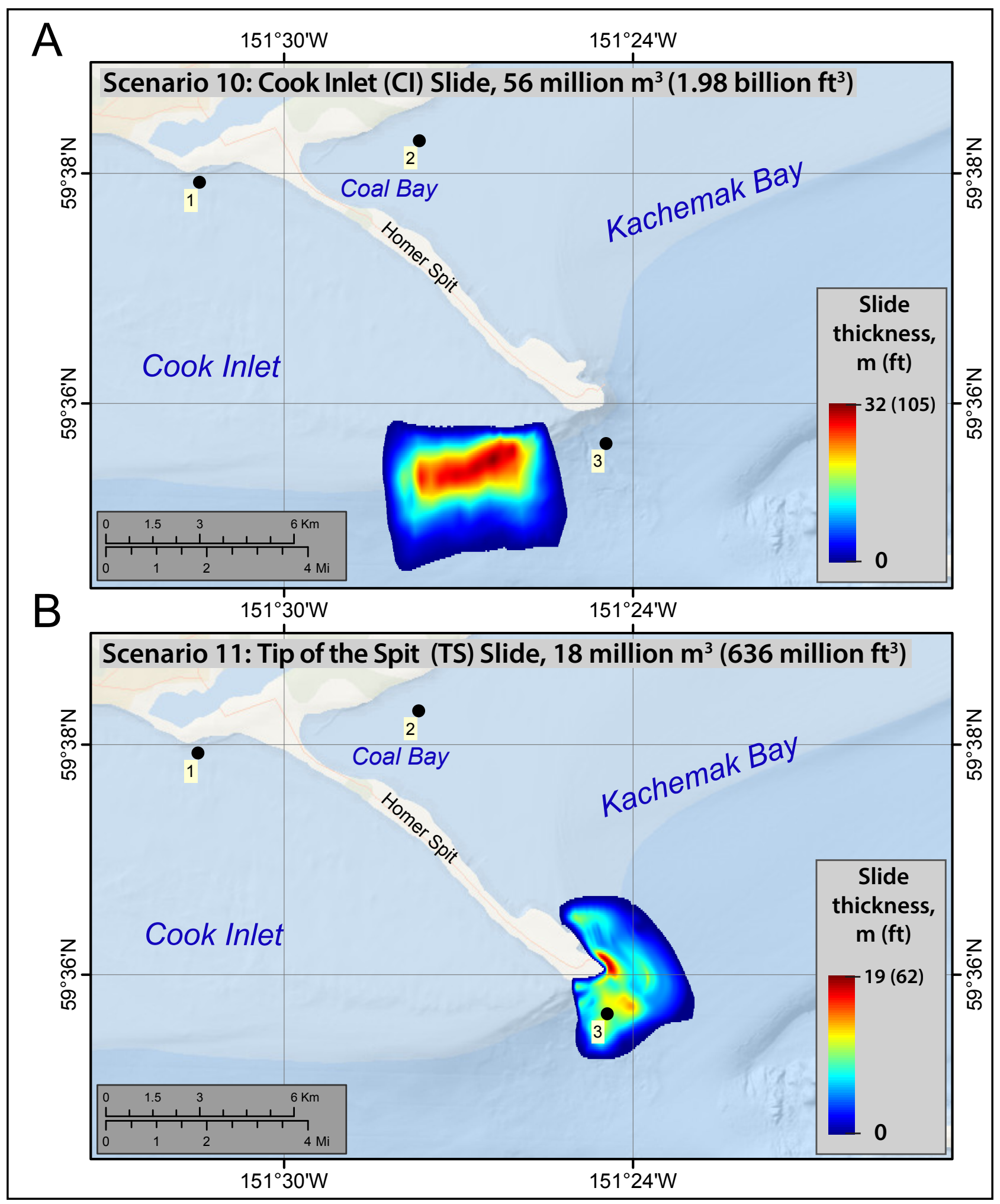

Figure 22. Locations and initial landslide thicknesses for hypothetical landslide scenarios A. Scenario 10, an underwater slide offshore of the Cook Inlet side of the Homer Spit. B. Scenario 11, an underwater slide offshore at the tip of the Homer Spit. Black dots indicate locations of time series stations, at which water-level dynamics was compared for scenarios 10 and 11 as shown in figure 29. 


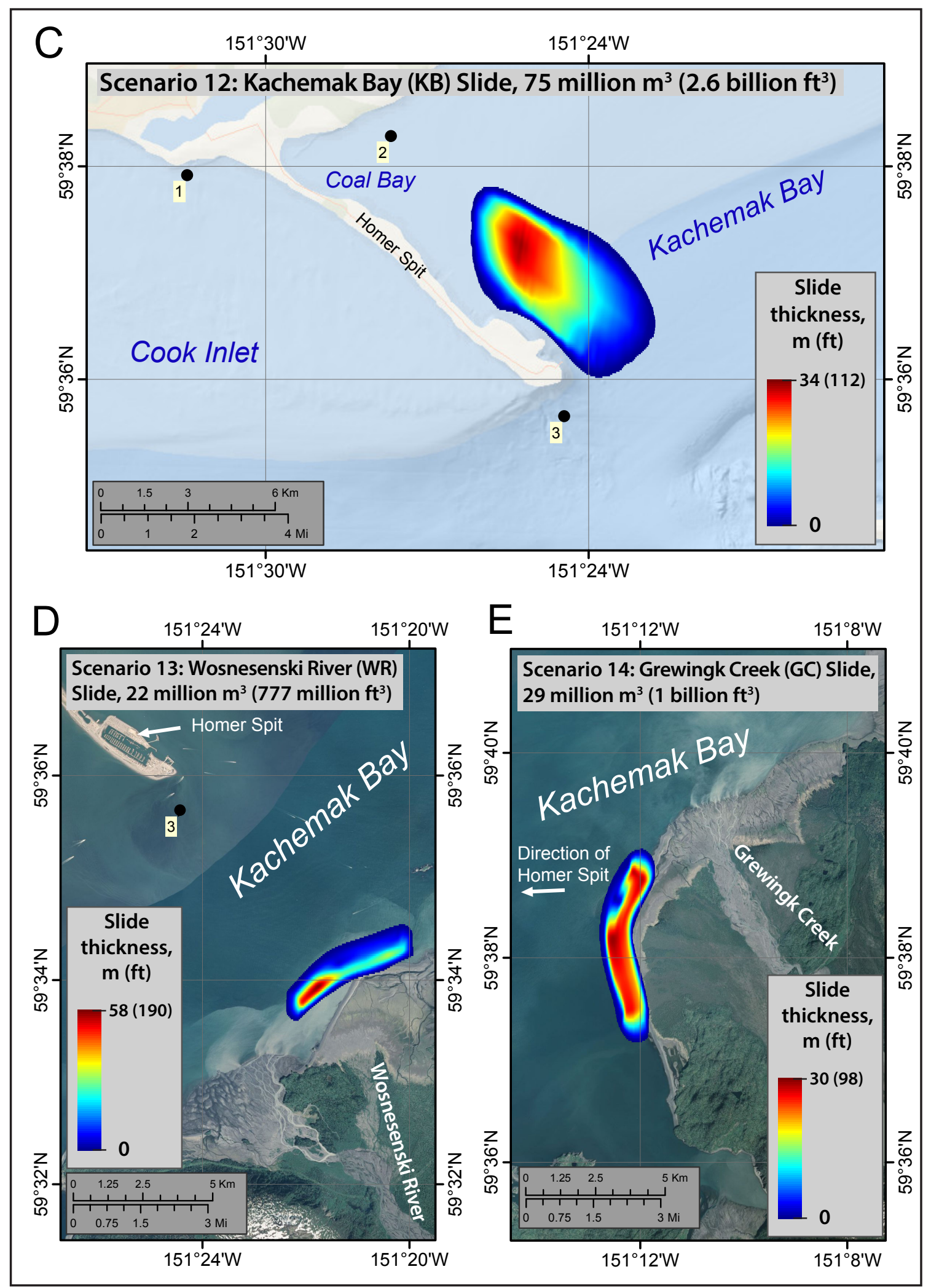

Figure 22, continued. Locations and initial landslide thicknesses for hypothetical landslide scenarios. C. Scenario 12, an underwater slide offshore of the Kachemak Bay side of the Homer Spit. D. Scenario 13, an underwater slide at the mouth of the Wosnesenski River. E. Scenario 14, an underwater slide at the mouth of the Grewingk Creek. Black dots indicate locations of time series stations, at which water-level dynamics was compared for scenarios 10 and 11 as shown in figure 29. 
we compute the composite maximum flow depth from all considered scenarios by again choosing the maximum value for each grid point among all scenarios. The calculated extent of inundation accounts for coseismic deformation in the communities. The same methodology is used to calculate the composite extent of tsunami inundation.

\section{Tectonic Scenarios}

The simulated extents of tsunami inundation in Homer and Seldovia for selected tectonic scenarios are shown in figures 23-25. From each group, we selected the scenario that resulted in the largest inundation zone in that group and plotted the corresponding inundation lines for Homer (fig. 23), Homer Spit (fig. 24), and Seldovia (fig. 25).
Scenario 1, the repeat of the 1964 Great Alaska Earthquake, does not result in any inundation in Homer except for the part of Lake Street that separates the tidal flats from Beluga Lake. Some low-lying parts of Homer Spit are flooded, but Homer Spit Road is not inundated. In Seldovia, scenario 1 results in inundation of the waterfront above the second block of houses in the harbor area.

In the second group, scenario 3 inundates Lake Street, which separates the tidal flats from Beluga Lake, and the areas between the tidal flats and the Sterling Highway. Scenario 3 almost completely inundates Homer Spit, with the exception of a few spots. In Seldovia, this scenario results in an inundation zone similar to that of scenario 1 .

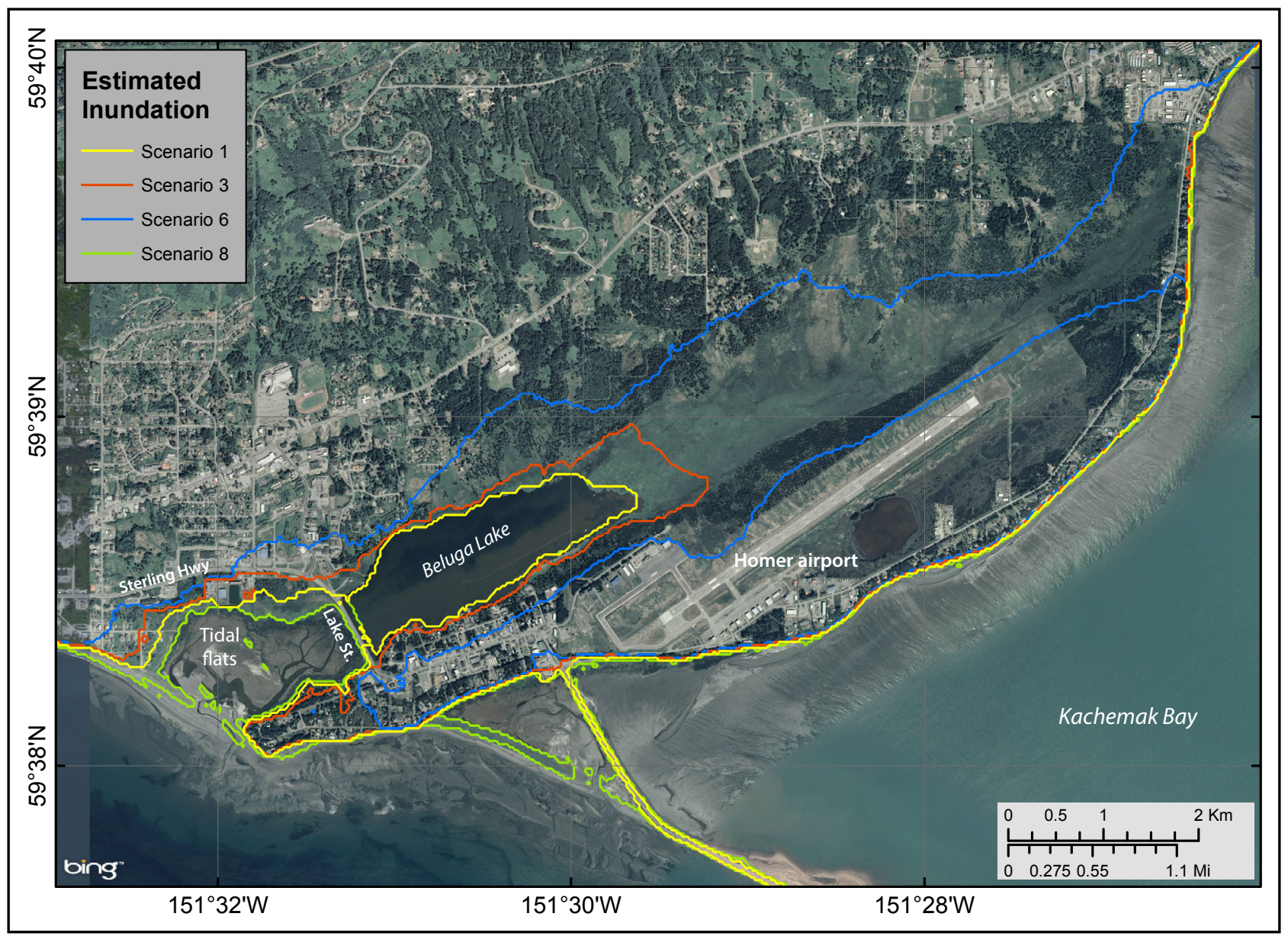

Figure 23. Modeled potential inundation for the town of Homer by tectonic tsunami waves for selected scenarios: scenario 1, the repeat of the $\mathrm{M}_{\mathrm{W}} 9.2$ Great Alaska Earthquake; scenario 3, a $\mathrm{M}_{\mathrm{W}} 9.3$ earthquake in the KI-KP region with predominantly shallow slip, and maximum slip at a depth of 5-15 km (3.1-9.3 mi); scenario 6, a $\mathrm{M}_{\mathrm{W}} 9.3$ earthquake in the $\mathrm{KI}-\mathrm{KP}$ region with maximum slip at a depth of 15-35 km (9.3-21.7 $\mathrm{mi})$, and uniform along-strike slip distribution; scenario 8, a $\mathrm{M}_{\mathrm{W}} 9.0$ earthquake according to the SAFRR project. 


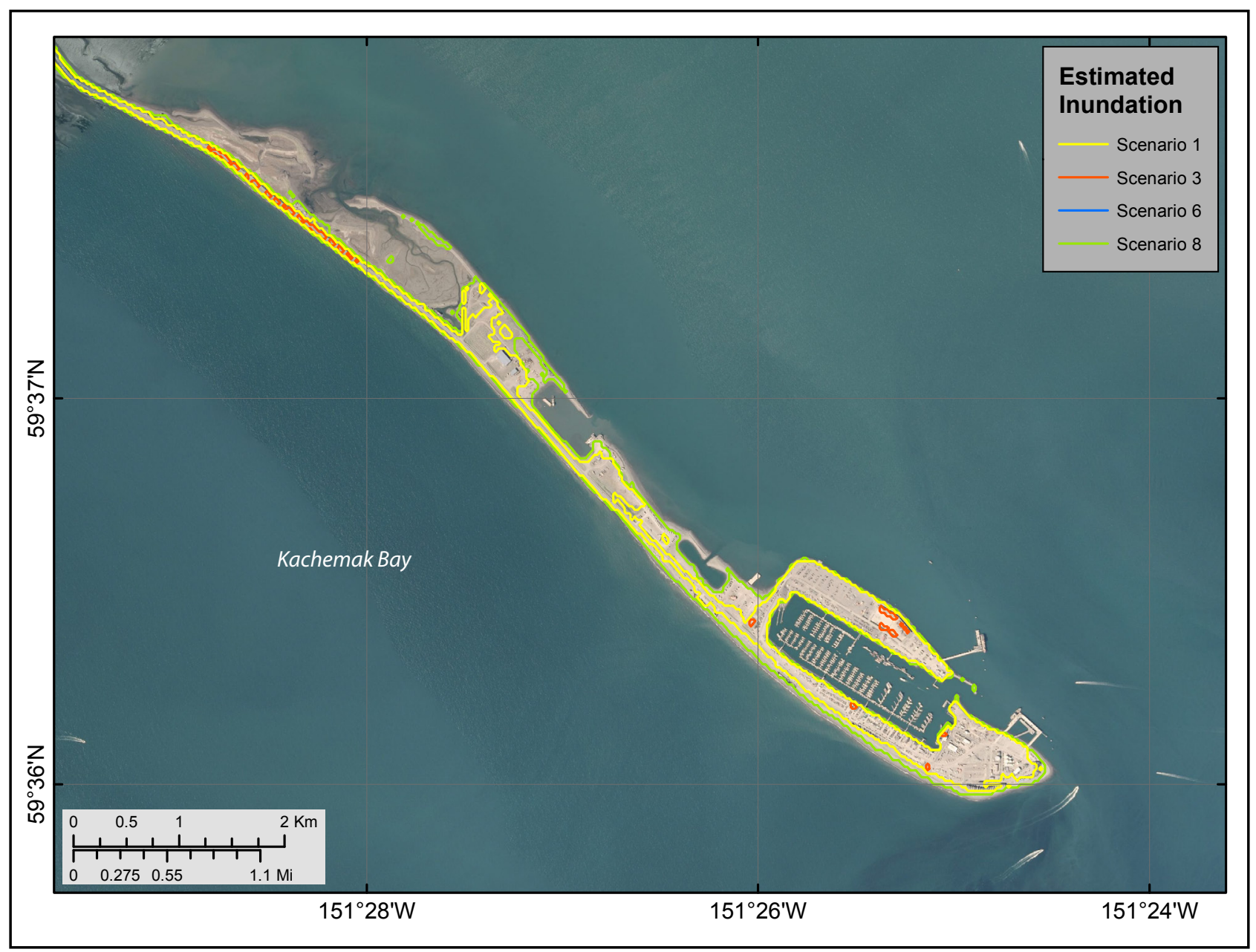

Figure 24. Modeled potential inundation for Homer Spit by tectonic tsunami waves for selected scenarios: scenario 1, the repeat of the $M_{W} 9.2$ Great Alaska Earthquake; scenario 3, a $M_{W} 9.3$ earthquake in the KI-KP region with predominantly shallow slip and maximum slip at a depth of 5-15 km (3.1-9.3 mi); scenario 6, a $\mathrm{M}_{\mathrm{W}} 9.3$ earthquake in the $\mathrm{KI}-\mathrm{KP}$ region with maximum slip at a depth of 15-35 km (9.3-21.7 $\mathrm{mi})$, and uniform along-strike slip distribution; scenario 8, a $\mathrm{M}_{\mathrm{W}} 9.0$ earthquake according to the SAFRR project.

In the third group, scenario 6 (maximum slip distributed between 15 and $35 \mathrm{~km}$ [9.3-21.7 mi] depth) results in the most severe inundation. The entire low-lying area of town from the Cook Inlet tidal flats to the Kachemak Bay shore (northeast of the airport landing strip), as well as some residential areas south of Beluga Lake and along the Sterling Highway, are inundated. This scenario also completely inundates Homer Spit; therefore the corresponding inundation line is not visible on Homer Spit. In Seldovia, it results in substantial inundation of the areas of town adjacent to the harbor and along Seldovia Slough, including the Seldovia airport.
In the fourth group, the tsunami modeled according to the SAFRR scenario (scenario 8) produces an inundation zone larger than that of scenario 9, the rupture of the Cascadia subduction zone. In Homer, the SAFRR scenario does not result in any inundation except for the tidal flats area. Some low-lying parts of Homer Spit are flooded, but Homer Spit Road is not overtopped by the modeled tsunami. In Seldovia, the model shows an inundation zone slightly less that that of scenario 1, which is the repeat of the 1964 Great Alaska Earthquake.

We use the predicted maximum flow depths from all hypothetical tectonic tsunami scenarios 


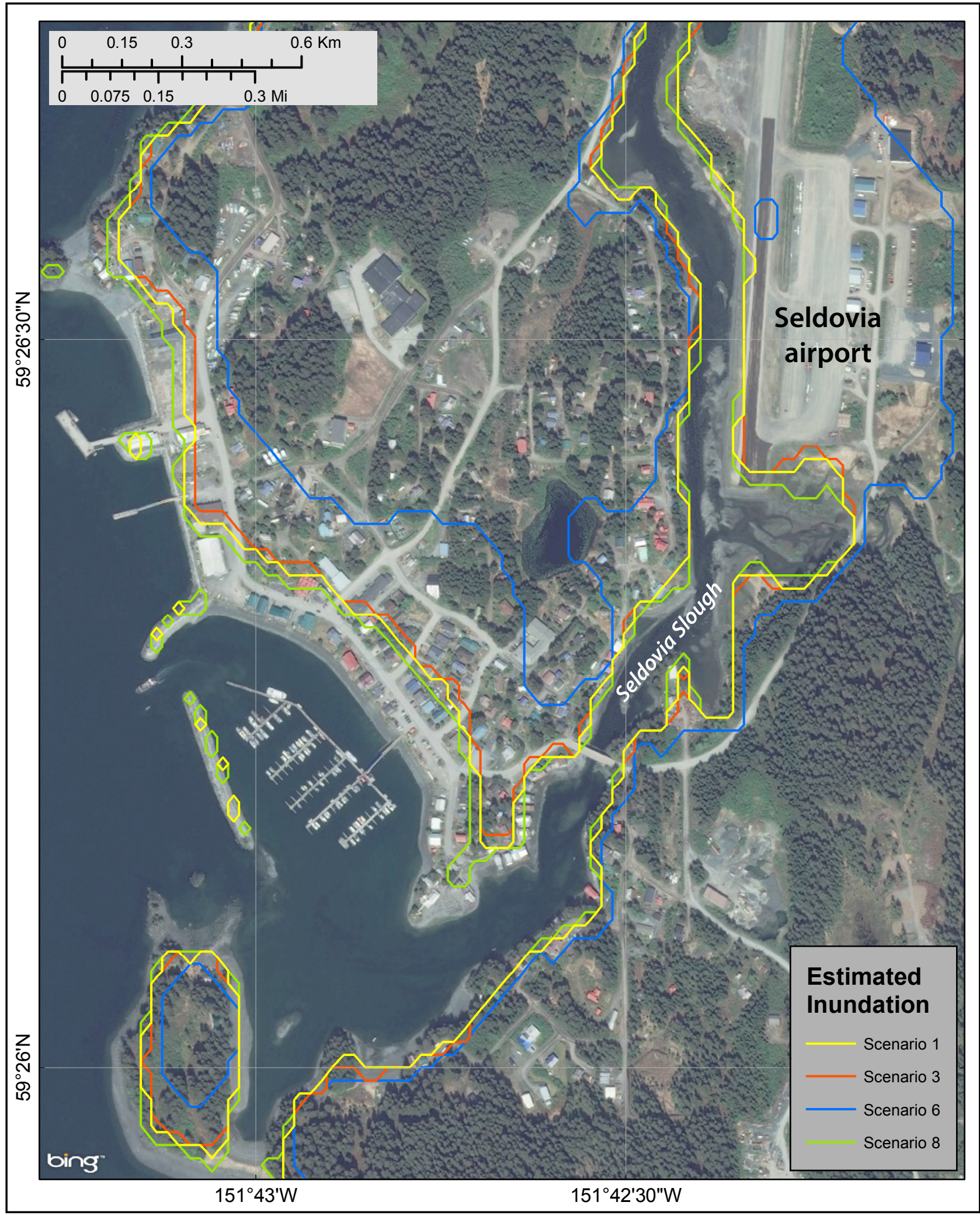

Figure 25. Modeled potential inundation for Seldovia by tectonic tsunami waves for selected scenarios: scenario 1, the repeat of the $\mathrm{M}_{\mathrm{W}} 9.2$ Great Alaska Earthquake; scenario 3, a $\mathrm{M}_{\mathrm{W}} 9.3$ earthquake in the KI-KP region with predominantly shallow slip, and maximum slip at a depth of 5-15 km (3.1-9.3 mi); scenario 6, a $\mathrm{M}_{\mathrm{W}} 9.3$ earthquake in the KI-KP region with maximum slip at a depth of 15-35 km (9.3-21.7 mi), and uniform along-strike slip distribution; scenario 8, a $\mathrm{M}_{\mathrm{W}} 9.0$ earthquake according to the SAFRR project. 
to develop maps of composite flow depths. We superpose all scenarios by selecting the maximum computed flow depth value at each grid point. Figures 26 and 27 show the composite tectonic flow depths over dry land for the town of Homer and for Homer Spit, respectively. The residential areas north and south of the tidal flats, areas north of Beluga Lake, some airport facilities, and a section of Kachemak Drive are all inside the inundation zone, with flow depths ranging from 3 to $5 \mathrm{~m}$ (10 to 16 $\mathrm{ft}$ ). Composite tectonic flow depths on Homer Spit reach $5 \mathrm{~m}(16 \mathrm{ft})$. Figure 28 shows the composite tectonic flow depths over dry land in Seldovia. A significant part of the waterfront and the airport area are inside the inundation zone, with flow depths ranging from 1 to $5 \mathrm{~m}$ (3.3 to $16 \mathrm{ft}$ ).

The numerical simulations reveal that, for some scenarios, the first wave could arrive at
Homer and Seldovia within one hour after the earthquake. As demonstrated by the time series data shown in appendix figures A3 and B3, significant wave activity could continue in the area for at least 12 hours after the earthquake, and the predicted average time interval between successive waves is 45 minutes to 1.5 hours.

\section{Landslide Scenarios}

While tectonically generated waves may not inundate the coast of Kachemak Bay for up to an hour after an earthquake, landslide-generated waves could hit low-lying areas while the ground is still shaking (Coulter and Migliaccio, 1966; Wilson and Tørum, 1968). Additionally, some landslide-generated waves can occur without an earthquake and therefore without any warning. We assume that slide-prone unconsolidated deposits are initially at rest, and ground shaking triggers

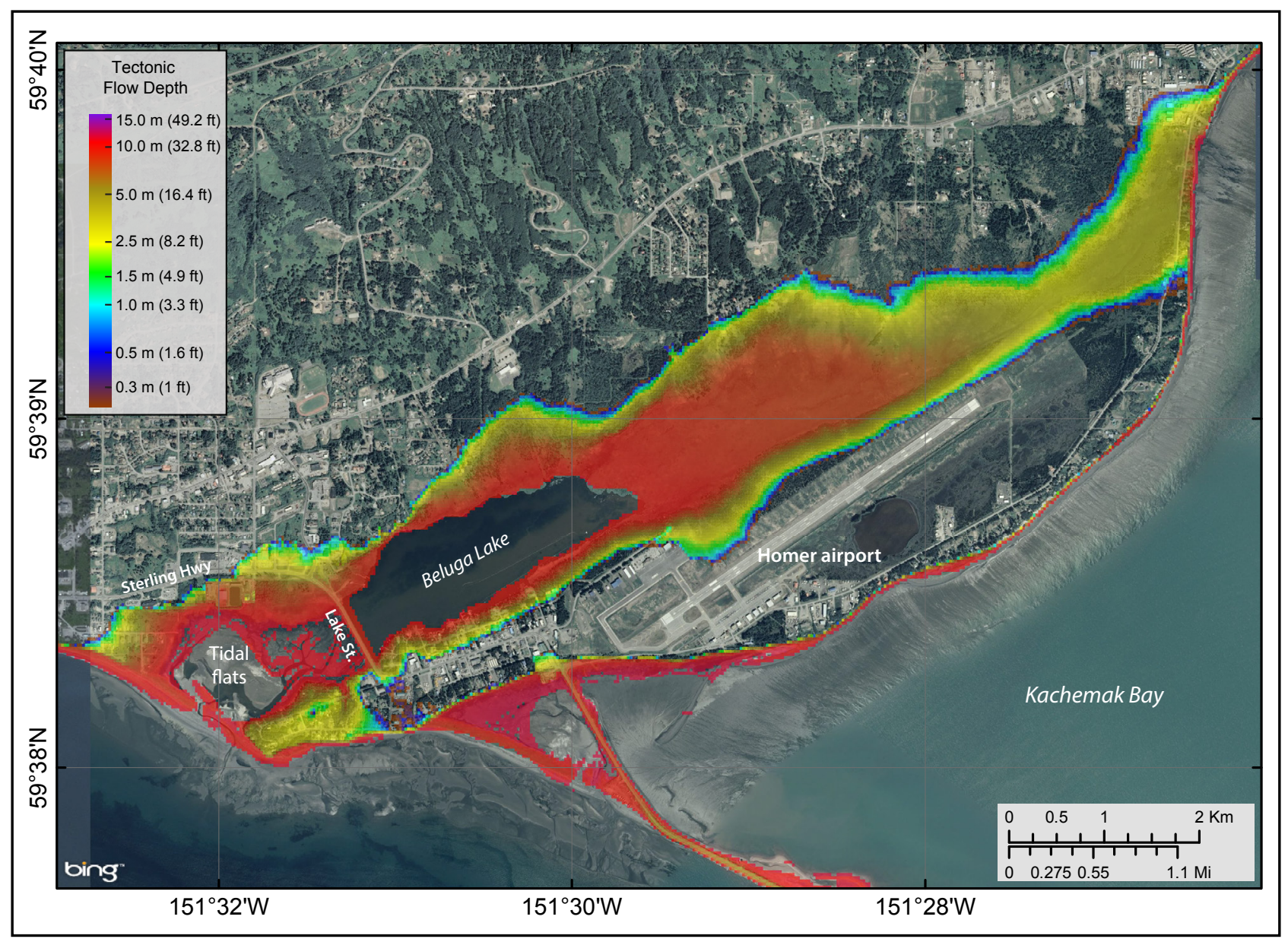

Figure 26. Modeled maximum composite flow depth over dry land for all tectonic scenarios for the town of Homer. 
the slide. The extents of potential slide sources in figure 8 .

First, we present the results of numerical coupling of the NHWAVE and FUNWAVE models. Because there is uncertainty associated with choosing the exact time to transfer the water level and velocities from NHWAVE to FUNWAVE, we select two distinct occasions. The uncertainty is later assessed by comparing water dynamics predicted by the NHWAVE and FUNWAVE models around the bay. For the sake of brevity we display only three locations near Homer Spit, shown in figure 22, at which the inter-model water level comparison is conducted. The results are shown in figures 29A and 29B for scenarios 10 and 11 , respectively. Despite slight differences in the FUNWAVE waveforms for two different time delays, NHWAVE and FUNWAVE modeling results - the amplitudes and periods of the waveforms - are in agreement. Moreover, the coupling is rather stable: changes in the NHWAVE water dynamics at two close time moments do not result in large changes of the FUNWAVE dynamics. Therefore, we conclude that coupling between the NHWAVE and FUNWAVE models is successful, both models simulate the tsunami similarly after the transfer of data, and most of the slide energy is adequately transferred to the water.

We stress that the modeling results are only conjectures of realistic landslide-generated tsunami dynamics. Recall that the initial landslide volume (fig. 22) is defined by an idealized failure surface, and the slide is modeled as a viscous fluid; hence the difference between the FUNWAVE and NHWAVE modeling results could be explained by perturbations in landslide geometry, assumed slide

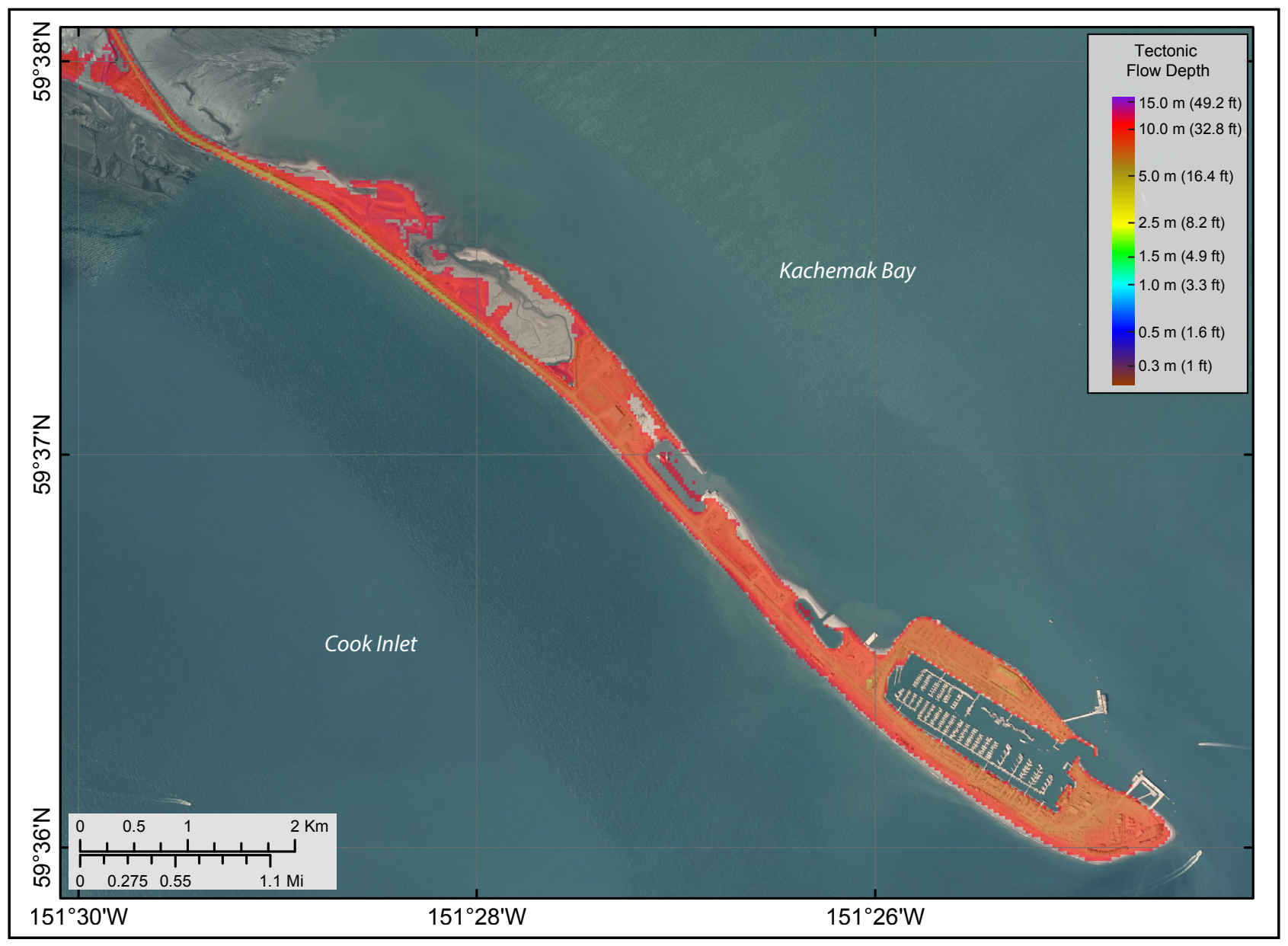

Figure 27. Modeled maximum composite flow depth over dry land for all tectonic scenarios for Homer Spit. 


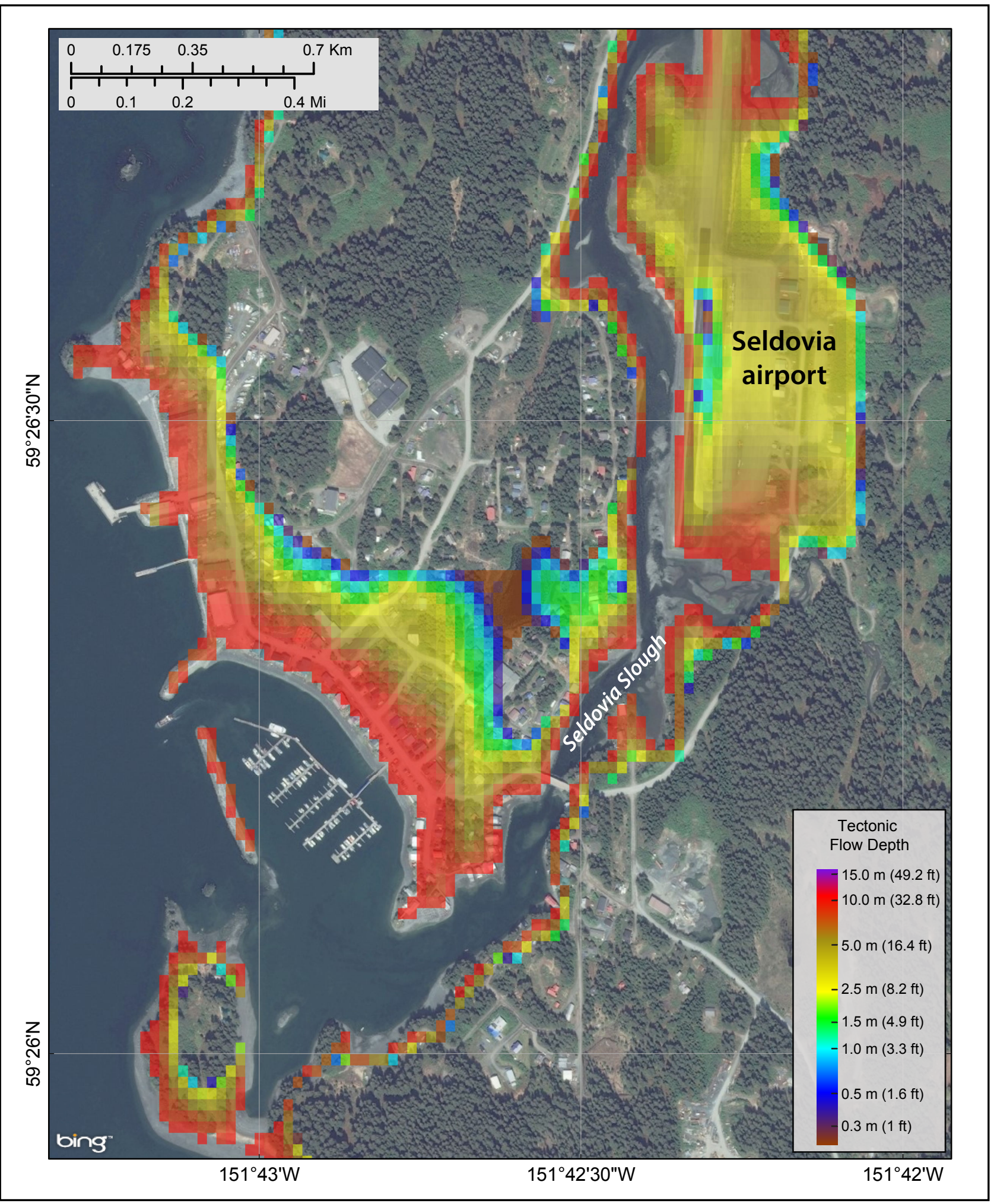

Figure 28. Modeled maximum composite flow depth over dry land for all tectonic scenarios for Seldovia. 


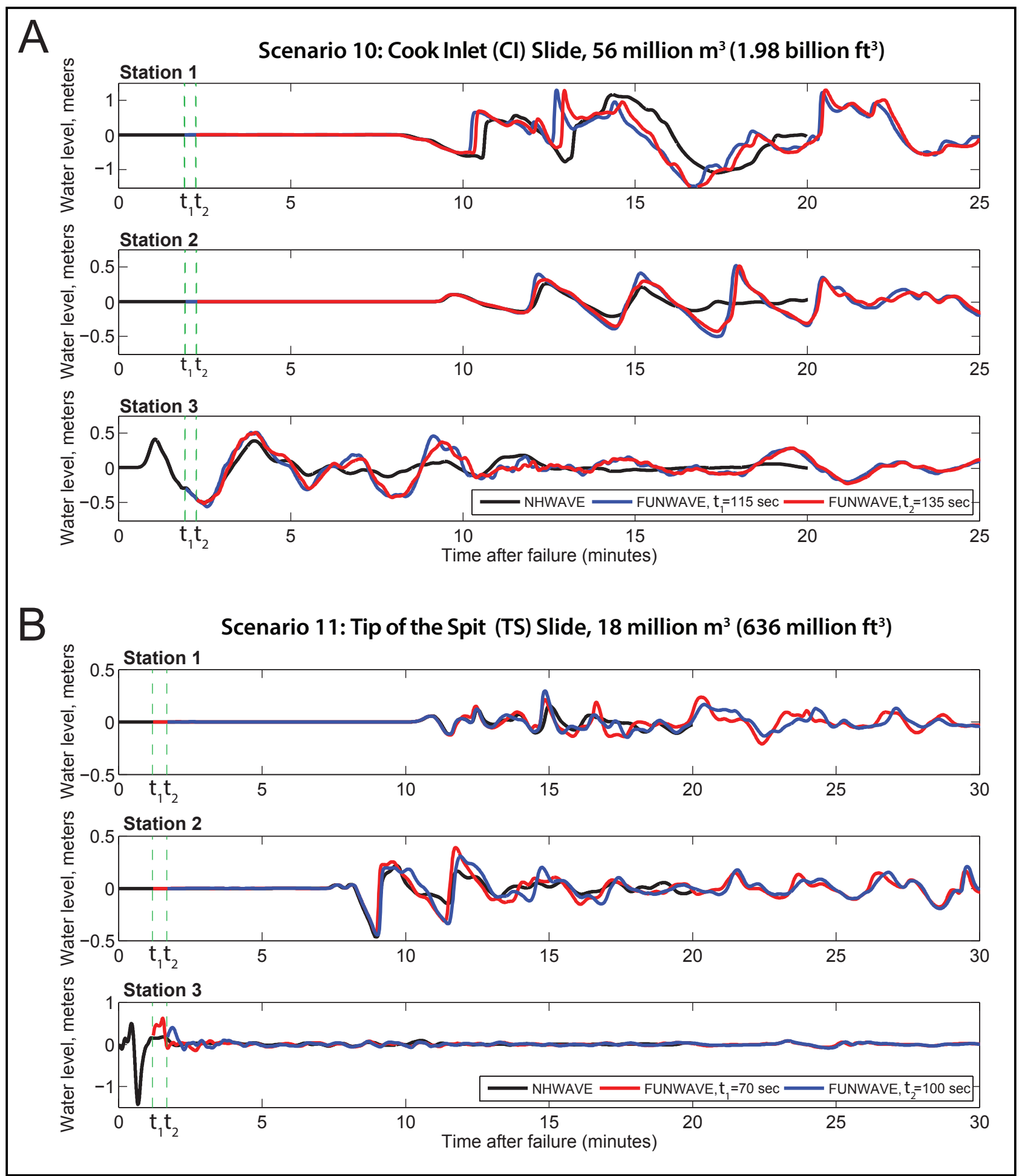

Figure 29. Comparison of scenarios 10 and 11 NHWAVE- and FUNWAVE-computed water-level dynamics at three stations, shown by black dots in figure 29A. The water level according to the initials NHWAVE calculation is plotted by the thick black line, while the water-level dynamics computed by FUNWAVE are plotted by red and blue lines for two different time delays $t_{1}$ and $t_{2}$. 
rheology, or by other model parameters. Thus, from the physical point of view, both FUNWAVE and NHWAVE results are plausible. Encompassing the maximum extent of flooding by NHWAVE and two iterations of FUNWAVE, we develop the extent of composite inundation for each scenario.

We use the two-stage NHWAVE-FUNWAVE methodology to model the inundation extents for all slide scenarios listed in table 5 . The modeling results demonstrate that runup extent strongly depends on slide volume. Figure 30 shows modeled inundation related to the Cook Inlet slide (scenario 10). The slide with inflated volume show expectedly larger inundation areas in Homer Spit: the tip of the spit and the business area adjacent to the western shore of the small-boat harbor are almost completely flooded and there are larger inundation areas in the middle of the spit where the Kevin Bell Arena is located. Results for scenario 10 show that the first wave reaches the tip of the spit within 3 minutes after the landslide (fig. 29A). The maximum wave height (above the MHHW level) in Kachemak Bay is shown in figures 31A-E for landslide scenarios 10-14, respectively. Figure 31A shows that this hypothetical Cook Inlet slide could generate waves $4-5 \mathrm{~m}(13-16 \mathrm{ft})$ high

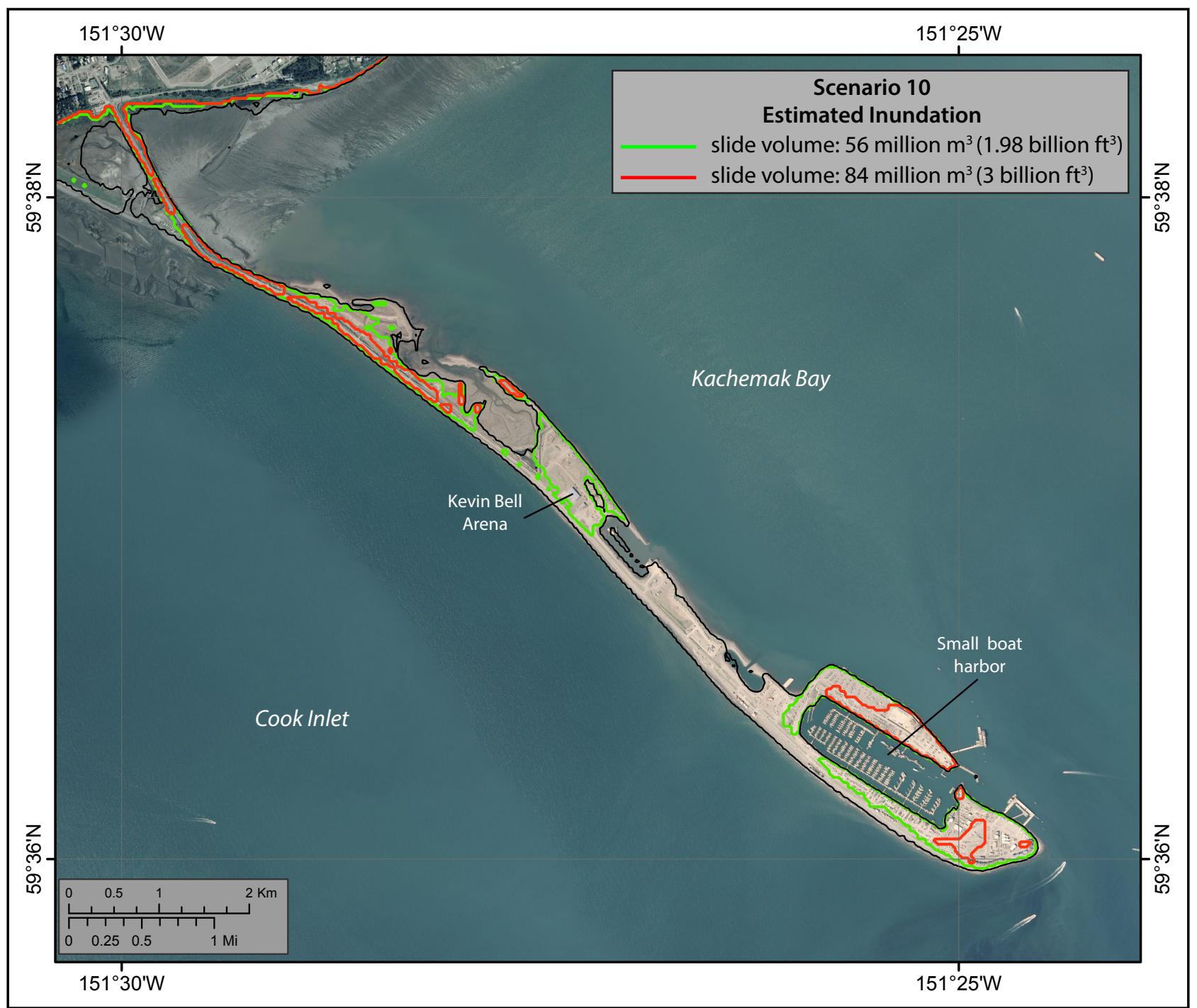

Figure 30. Results of the enhanced scenario 10 for increased volume of the landslide. Modeled inundation related to the Cook Inlet slide with a volume of 56 million $\mathrm{m}^{3}$ (73 million yd $\left.{ }^{3}\right)$ is shown by the green line; inundation for the slide with 50 percent volume increase is plotted by the red line. 
above MHHW level along the western shore of Homer Spit.

The Tip of the Spit slide (scenario 11) could generate a tsunami that floods low-lying areas at the tip of Homer Spit with a wave height of about $2 \mathrm{~m}(6.5 \mathrm{ft})$ above MHHW level, as shown in figure $31 \mathrm{~B}$. The first wave reaches the tip of the spit within 1 minute after the landslide, and the waves arrive at the landward end of the spit in about 10-15 minutes (fig. 29b).

The Kachemak Bay slide (scenario 12) could generate $2-5 \mathrm{~m}(6.5-16 \mathrm{ft})$ high waves at the eastern shore of Homer Spit, overtopping the middle section of the spit and Homer Spit Road (fig. 31C). Another inundated area is at the base of the spit, on the shores of Coal Bay next to the Homer airport, but Homer Spit Road remains intact at the entrance to the spit. Even though the major wave activity happens on the Kachemak Bay side of Homer Spit, the waves refract around the spit and inundate the tidal flats west of Beluga Lake. The first wave arrives in Coal Bay about 10 minutes after the landslide, and it takes the wave about 12 minutes to reach the opposite shore of Homer Spit.

The Woznesenski River slide (scenario 13, fig. 31D) is especially hazardous for the end of Homer Spit because wave energy is directed straight at the small boat harbor. This slide could generate a tsunami that floods low-lying areas at the tip of the spit with wave heights of $5 \mathrm{~m}(16 \mathrm{ft})$ above MHHW level. The wave heights in the small-boat harbor could reach $2 \mathrm{~m}(6.5 \mathrm{ft})$ and dangerous sea level oscillations and water currents are likely. Another inundated area is at the base of Homer Spit, on the shores of Coal Bay next to the Homer airport where a section of Kachemak Drive gets flooded. It takes the wave about 2 minutes to reach the tip of the spit and the first wave reaches Coal Bay about 7 minutes after the landslide.

Finally, in scenario 14 (fig. 31E), we simulate a tsunami triggered by a landslide just north of
Halibut Cove. The wave energy is directed mainly toward the northern shore of Kachemak Bay, as well as the western shore of Homer Spit. The landslide generates waves up to $4 \mathrm{~m}(13 \mathrm{ft})$ high in the source area, and up to $2 \mathrm{~m}(6.5 \mathrm{ft})$ high in Kachemak Bay close to Homer Spit. This scenario does not result in inundation of Homer Spit, except for a small area just north of the small boat harbor next to Pier One Theatre. The first wave arrives in Coal Bay in 3 minutes, and after about 5 minutes it reaches the tip of the spit.

Numerical simulations of these landslide-generated tsunami scenarios indicate that the first wave can arrive at the end of Homer Spit in less than 1 minute (scenario 11, the Tip of the Spit slide). Plots of water level dynamics near the city for all landslide scenarios are shown in appendix figure A6. The composite water flow depth for landslide scenarios is shown in fig. 32. We emphasize that tsunami currents could be strong, and water oscillations in the small boat harbor at the end of Homer Spit could result in substantial damage to the harbor and fleet.

\section{Composite Inundation}

We use the predicted maximum flow depths from both hypothetical landslide-generated and tectonic tsunamis to develop the composite flow depth maps for Homer and Seldovia. We superpose the inundation from tectonic scenarios 1-9 with inundation from landslide-generated tsunami scenarios $10-14$ by selecting the maximum computed flow depth values at each grid point. Map sheets 2 and 3 show the maximum composite calculated extent of inundation and maximum composite flow depths over dry land in Homer and on Homer Spit, respectively. Map sheet 5 illustrates the maximum composite calculated extent of inundation and maximum composite flow depths over dry land for Seldovia, but only for tectonic scenarios, because the considered landslide scenarios do not result in any noticeable tsunami effects in Seldovia. Map sheets 6 and 7 cover other areas around Sedlovia Bay. Map sheets 


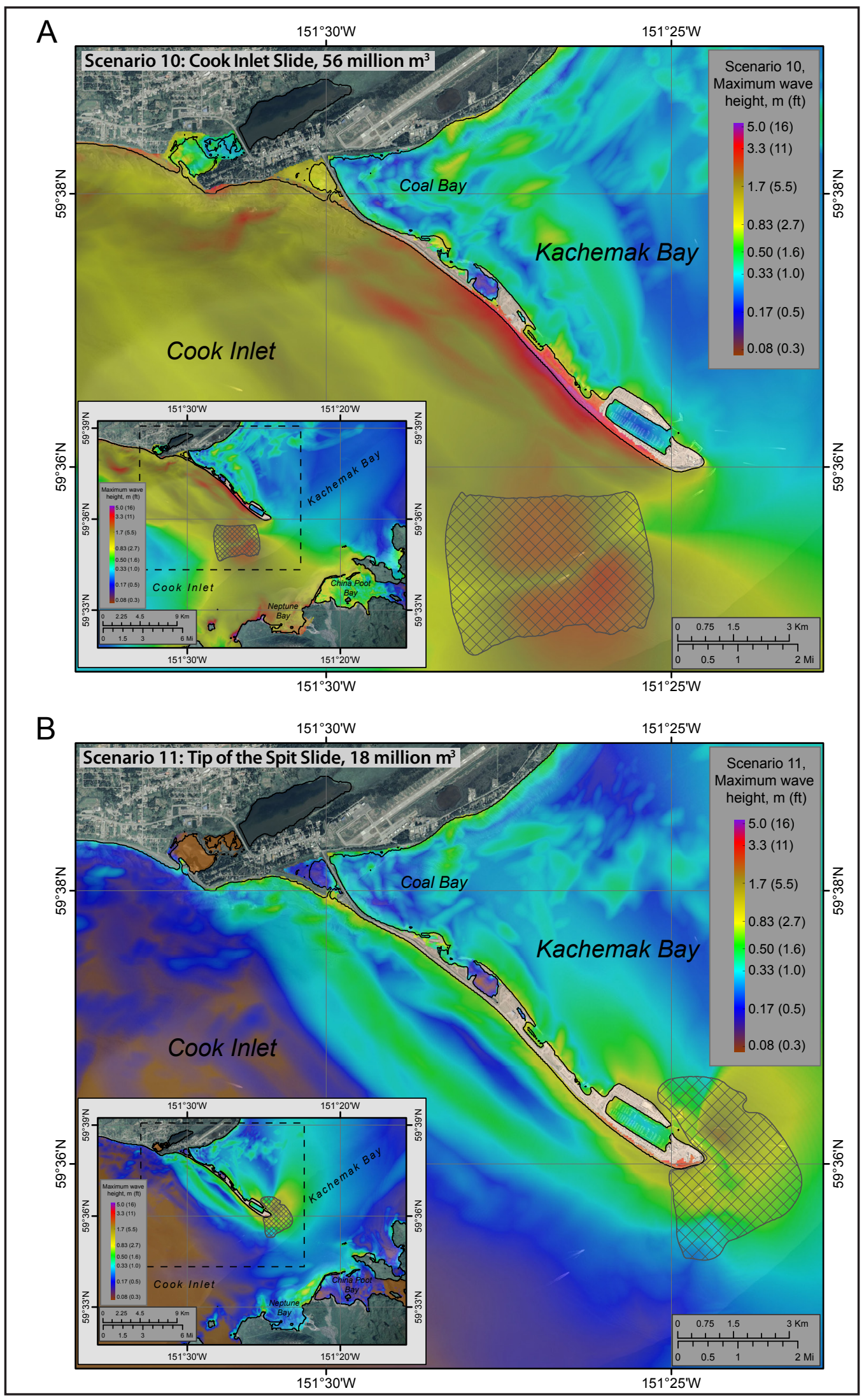

Figure 31. Maximum wave height above the MHHW level in Kachemak Bay for landslide scenarios. A. Scenario 10, an underwater slide offshore of the Cook Inlet side of Homer Spit. B. Scenario 11, an underwater slide offshore at the tip of Homer Spit. 


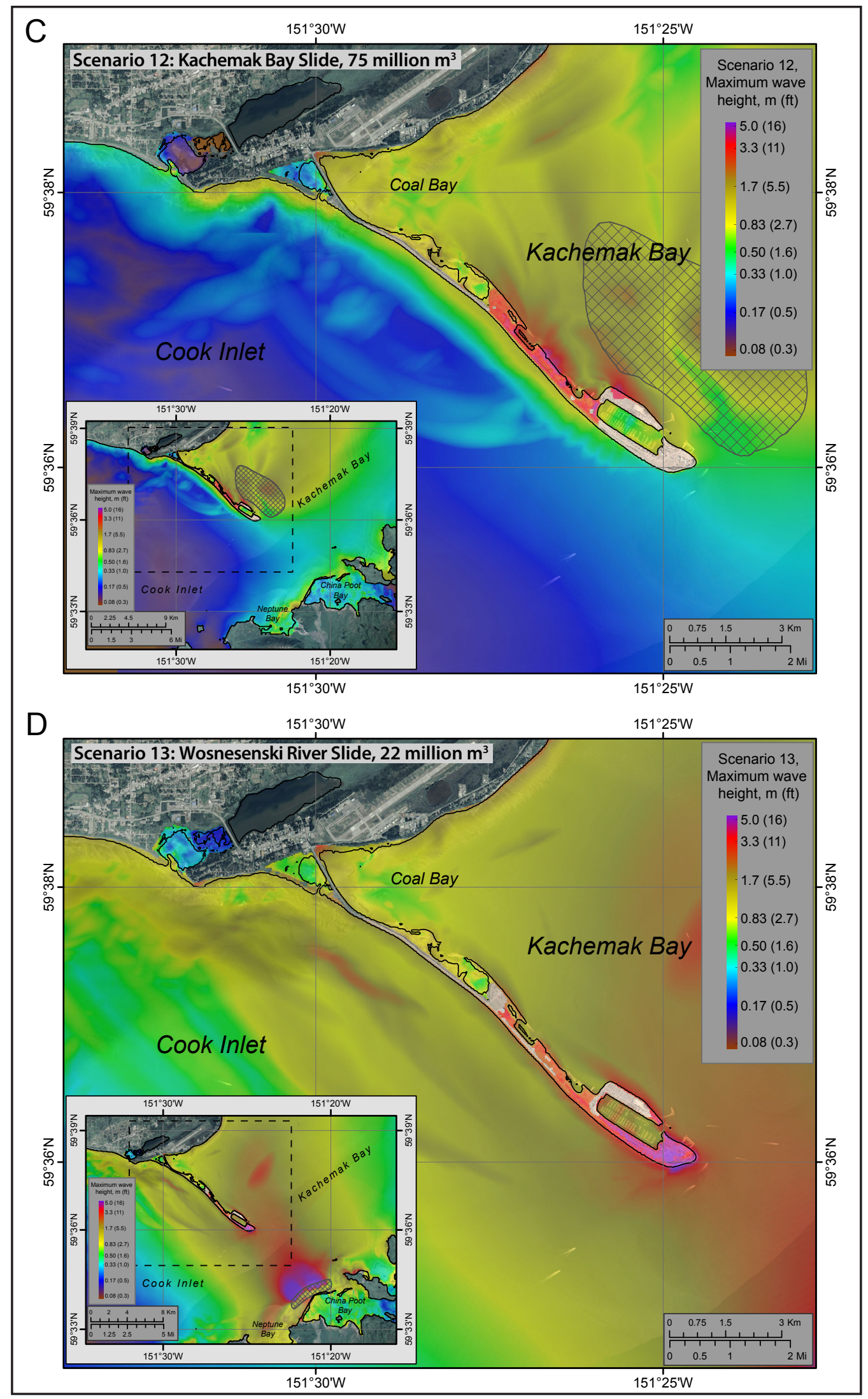

Figure 31 continued. Maximum wave heightabove the MHHW level in Kachemak Bayforlandslide scenarios. C. Scenario 12, an underwater slide offshore of the Kachemak Bay side of Homer Spit. D. Scenario 13, an underwater slide at the mouth of the Wosnesenski River. 


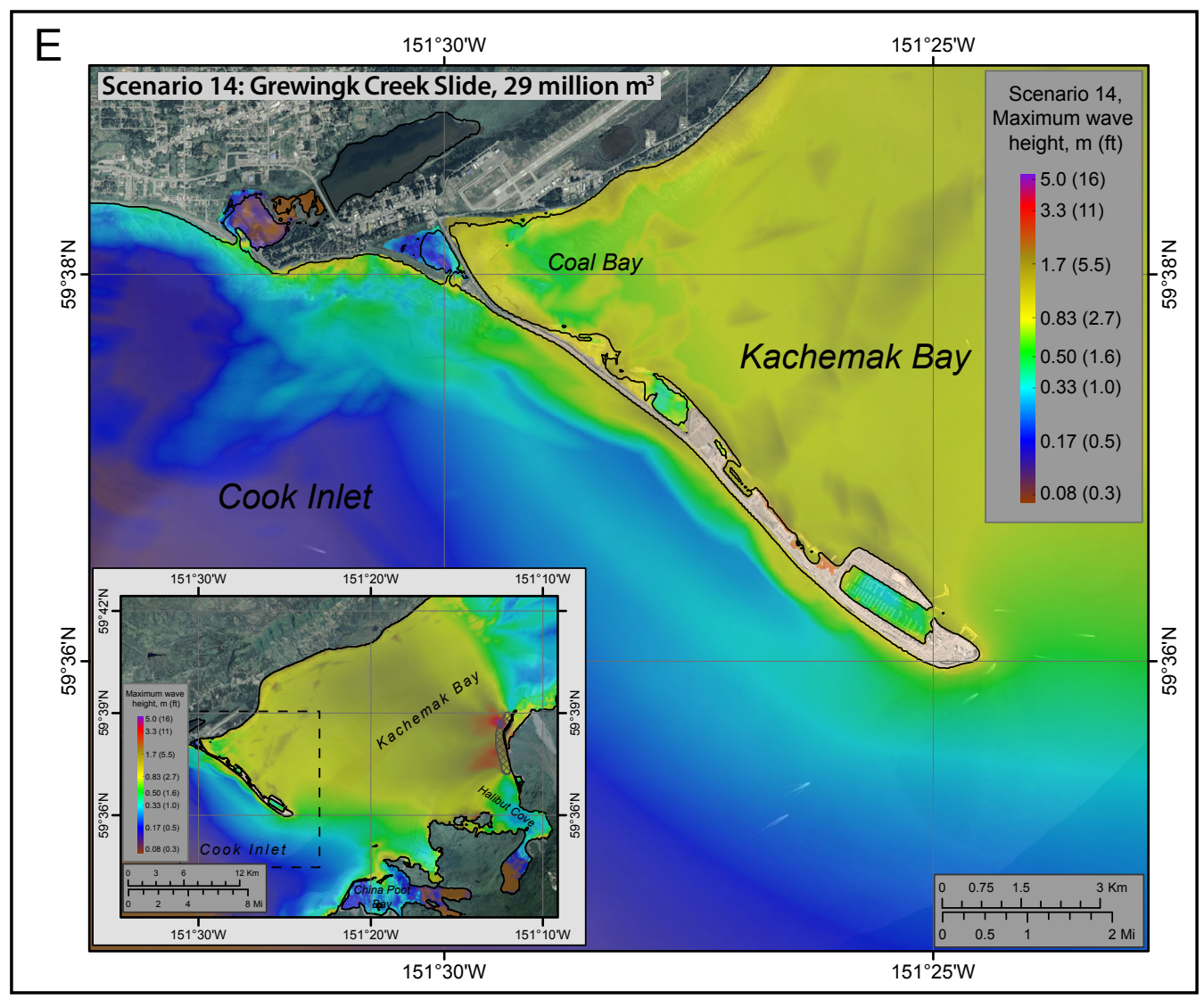

Figure 31, continued. Maximum wave height above the MHHW level in Kachemak Bay for landslide. E. Scenarios 14, an underwater slide at the mouth of the Grewingk Creek.

8-11 cover Seldovia Village and Jakolof Bay and are described in Appendix C.

\section{Time Series and Other Numerical Results}

We supplement inundation maps with time series of modeled water levels and velocity dynamics at certain locations around the towns to provide emergency managers with the tools necessary to completely assess the tsunami hazard for Homer (Appendix A) and Seldovia (Appendix B). Emergency managers should consider the arrival time of the first wave, the maximum wave amplitude, and the duration of wave action during their evacuation and response planning.

For each location shown by a number in figures A1, A2, B1, and B2, we plot sea level and water velocity according to both scenarios in figures A3 and B3. Time zero corresponds to the earthquake origin time. Elevations of onshore locations and values of ocean depth at offshore locations are based on the pre-earthquake MHHW datum. Because velocity magnitude is calculated as water flux divided by water depth, the velocity value has large uncertainties in shallow water. In these plots, velocity is computed only where water depth is greater than $0.3 \mathrm{~m}(1 \mathrm{ft})$.

Our maximum simulated water level results from scenario 6 due to the combination of tectonic subsidence coupled with a large incoming tsunami.

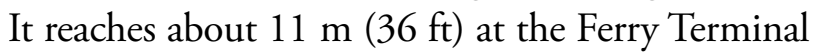
on Homer Spit (point 14, fig. A4) and about $10 \mathrm{~m}$ (33 ft) in the boat harbor in Seldovia (point 10, fig. B4). It takes about 2 hours for the water level to reach its maximum level after the earthquake. This time should be sufficient to evacuate Homer Spit in the event of this worst-case scenario. 


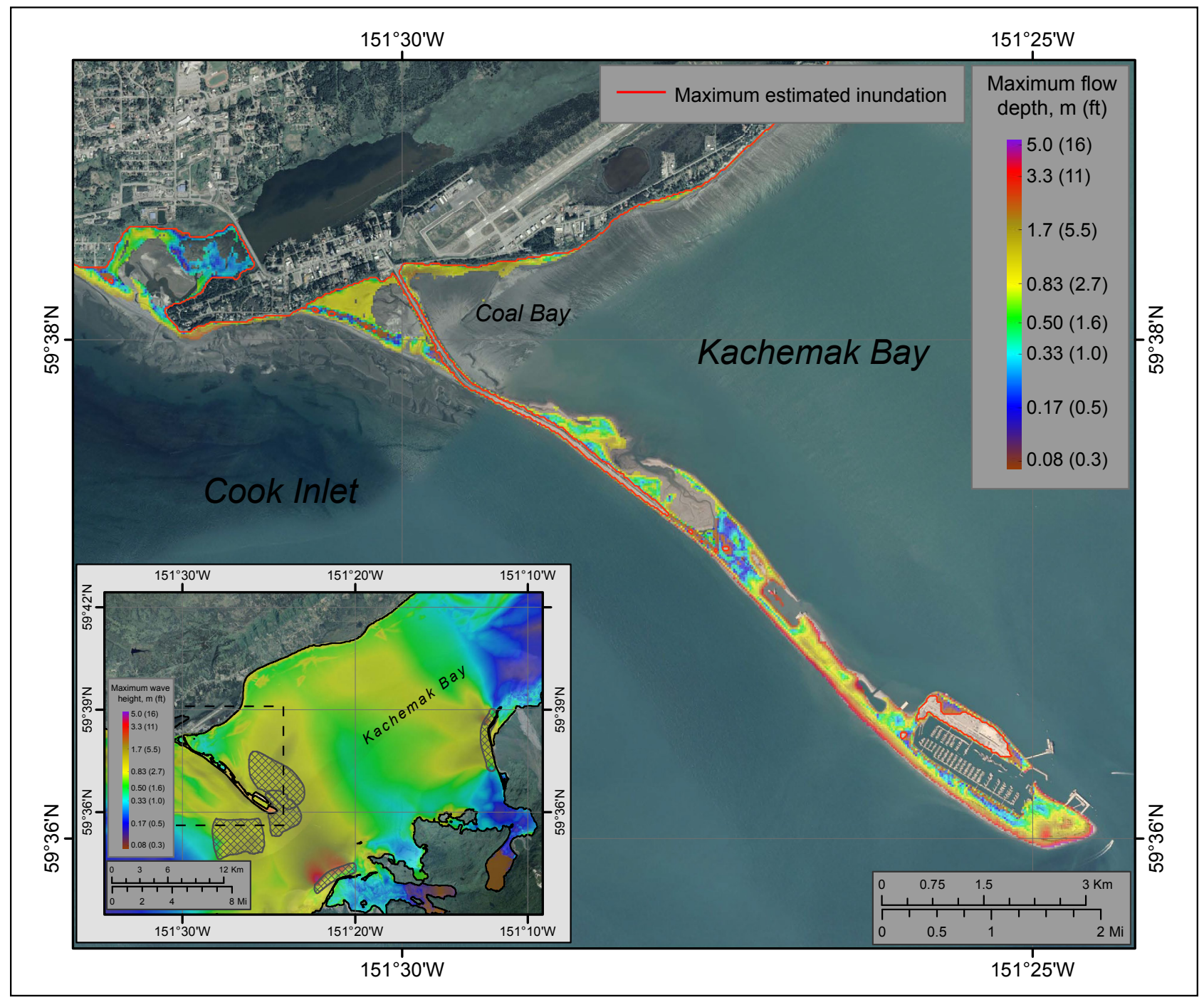

Figure 32. Maximum composite flow depth over dry land and maximum composite extent of inundation for landslide scenarios in Homer.

The strongest tsunami currents result from scenario 5. For Homer, currents reaching $11 \mathrm{~m} / \mathrm{s}$ $(36 \mathrm{ft} / \mathrm{s} ; 21$ knots) occur at the Glacier Drive-in Café (point 10, fig. A4) about 4 hours after the earthquake. For Seldovia, currents reaching 6.5 $\mathrm{m} / \mathrm{s}(8.8 \mathrm{ft} / \mathrm{s} ; 5.2$ knots $)$ occur under the main bridge in Seldovia (point 14, fig. B4) about 5 hours after the earthquake. Tsunami activity continues for at least 12 hours. Maximum wave heights at selected locations are listed in tables A-1 and B-1 for Homer and Seldovia, respectively.

Because water level oscillations can continue for more than a full day, even if the earthquake occurs during low tide these oscillations will be affected by the subsequent rising tide. Low-lying areas that were not initially flooded may become inundated 24-48 hours after the earthquake. Another important factor in tsunami hazard assessment for any coastal community is the arrival time of the first wave. The time series plots demonstrate that the first wave could arrive at both Homer and Seldovia within 1 hour after the earthquake. However, underwater landslides in the vicinity of Homer and Seldovia are capable of producing waves that could reach onshore locations within minutes after slope failure. Plots of modeled water levels and velocities for local landslide-generated tsunamis are shown in figure A4. Because 
landslide-generated tsunamis are simulated with both NHWAVE and FUNWAVE models using the two-stage approach, we provide time series for both models. Recall that FUNWAVE was initialized at some time after the slide collapse; hence FUNWAVE results are not available at the beginning of each scenario. Providing all modeling results allows us to estimate the uncertainty in the wave height modeling. The arrival time characterizes the vulnerability of a community to tsunami hazard-this metric has special significance for local emergency officials in evacuation planning.

\section{Sources of Errors and Uncertainties}

The hydrodynamic model used to calculate propagation and runup of tectonic tsunamis is a nonlinear, flux-formulated, shallow-water model (Nicolsky Suleimani, and Hansen, 2011; Nicolsky, 2012) that passed the verification and validation tests required for numerical codes used to produce tsunami inundation maps (Synolakis and others, 2007; National Tsunami Hazard Mitigation Program [NTHMP], 2012). The NHWAVE and FUNWAVE models used to simulate inundation from landslide-generated tsunamis have also passed the same NHTMP verification and validation tests (Tehranirad and others, 2012). Most of the errors/uncertainties in the numerical predictions originate from the tsunami sources used in the numerical models. Due to insufficient data on locations and volumes of hypothetical subaerial landslides, we do not model tsunamis generated by this type of landslide even though they present a significant hazard to Alaska coastal communities. Furthermore, our assessment of potential earthquake scenarios and submarine slope failures is not exhaustive and only represents a best estimate of the locations and sizes of potential tsunami-generating events. It is possible that other unrecognized earthquake scenarios or slope failures could present hazards to these communities. However, the scenarios presented are intended to adequately cover the range of potential situations about which the communities should be aware.
The spatial resolution of the grid used to calculate tsunami inundation at Homer and Seldovia is about $16 \mathrm{~m}(52.5 \mathrm{ft})$ and satisfies NOAA minimum recommended requirements for computation of tsunami inundation (National Tsunami Hazard Mitigation Program [NTHMP], 2010). This resolution is high enough to describe major relief features; however, small topographic features, buildings, and other facilities cannot be resolved accurately by the existing model. We also note that uncertainty in grid cell elevation/depth propagates into the modeling results and eventually contributes to the horizontal uncertainty in the location of an inundation line. One of the contributors to this uncertainty is the paucity of data in the intertidal zone. However, no established practices exist to directly propagate the DEM uncertainty into the uncertainty of the inundation line (Hare and others, 2011). In addition to the uncertainty related to the grid cell elevation/depth, uncertainties in the tsunami source (earthquake and landslide geometry) are the largest sources of error in tsunami modeling efforts. The direction of the incoming waves, their amplitudes, and times of arrival are primarily determined by displacements of the ocean surface in the source area. Therefore, the inundation modeling results for local sources are especially sensitive to the fine structure of the tsunami source. The modeling process is highly sensitive to errors when the complexity of the source function is combined with its proximity to the coastal zone. The current practice is to create some additional buffer area around the inundation line to use for hazard mitigation and decisions related to tsunami evacuation.

\section{SUMMARY}

We present the results of numerical modeling of hypothetical tectonic and submarine landslide-generated tsunami waves for the towns of Homer and Seldovia, and small communities Seldovia Village, Jakolof Bay, and Kachemak Selo in Southcentral Alaska. Each of these scenarios is geologically reasonable and presents potential hazards to the community. Scenario 6, a 
megathrust earthquake in the KI-KP region with maximum slip at a depth of $15-35 \mathrm{~km}$ (9.3-21.7 $\mathrm{mi})$, results in the largest inundation area in both Homer and Seldovia. The Kachemak Bay slide and the Wosnesenski River slide both result in partial flooding of Homer Spit and present significant tsunami hazards for businesses and operations located on Homer Spit.

The maps that are part of this report have been completed using the best information available and are believed to be accurate; however, their preparation required many assumptions. We considered a number of tsunami scenarios and have provided an estimate of maximum credible tsunami inundation. Actual conditions during a tsunami event may vary from those considered, so the report's accuracy cannot be guaranteed. The limits of inundation shown should only be used as a guideline for emergency planning and response action. Actual inundated areas will depend on specifics of earth deformations, on-land construction, and tide level, and may differ from areas shown on the map. The information on this map is intended to assist state and local agencies in planning for emergency evacuation and tsunami response actions in the event of a major tsunamigenic earthquake. These results are not intended for land-use regulation or building-code development.

\section{ACKNOWLEDGMENTS}

This report was funded by Award NA15NWS4670027 by a National Tsunami Hazard Mitigation Program grant to the Alaska Division of Homeland Security and Emergency Management and University of Alaska Fairbanks from the Department of Commerce/National Oceanic at Atmospheric Administration. This does not constitute an endorsement by NOAA. Numerical calculations for this work were supported by High Performance Computing (HPC) resources at the Research Computing Systems unit at the Geophysical Institute, University of Alaska Fairbanks. Thoughtful reviews by Michael West (Alaska Earthquake Center), Peter Haeussler (USGS, Alaska Science Center) and an anonymous reviewer improved the report. 


\section{REFERENCES}

Begét, J.E., and Kienle, J., 1992, Cyclic Formation of Debris Avalanches at Mount St. Augustine Volcano, Alaska: Nature 356, p. 701-704.

Begét, J.E., Gardner, Cynthia, and Davis, Kathleen, 2008, Volcanic tsunamis and prehistoric cultural transitions in Cook Inlet, Alaska: Journal of Volcanology and Geothermal Research, v. 176, no. 3, p. 377-386. https://doi. org/10.1016/j.volgeores.2008.01.034

Briggs, R.W., Engelhart, S.E., Nelson, A.R., Dura, T., Kemp, A.C., Haeussler, P.J., Corbett, D.R., Angster, S.J., and Bradley, L.-A., 2014, Uplift and subsidence reveal a nonpersistent megathrust rupture boundary (Sitkinak Island, Alaska): Geophysical Research Letters, v. 41, no. 7, p. 2,289-2,296. http://doi. org/10.1002/2014GL059380

Brothers, D.S., Haeussler, P. J., Liberty, L., Finlayson, D., Geist, E., Labay, K., and Byerly, M., 2016, A submarine landslide source for the devastating 1964 Chenega tsunami, southern Alaska: Earth and Planetary Science Letters, v. 438, p. 112-121. https://doi.org/10.1016/j. epsl.2016.01.008

Butler, Rhett, 2012,Re-examination of the potential for great earthquakes along the Aleutian island arc with implication for tsunamis in Hawai' $\mathrm{i}$ : Seismological Research Letters, v. 83, no. 1, p. 30-39. http://doi.org/10.1785/gssrl.83.1.29

Butler, Rhett, 2014, Great Aleutian tsunamis: Honolulu, HI, University of Hawai'i at Manoa, Hawai'i Institute of Geophysics \& Planetology, Peer-Reviewed Report HIGP-2014-1, 170 p. www.higp.hawaii.edu/reports/2014

Butler, Rhett, Burney, David, and Walsh, David, 2014, Paleo-tsunami evidence on Kaua'i and numerical modeling of a great Aleutian tsunami: Geophysical Research Letters, v. 41, no. 19, p. 6,795-6,802. http://doi. org/10.1002/2014GL061232

Buurman, H., and West, M., 2010, Seismic precursors to volcanic explosions during the 2006 eruption of Augustine Volcano, in Power,
J.A., Coombs, M.L., and Freymueller, J.T., eds., The 2006 Eruption of Augustine Volcano: U.S. Geological Survey Professional Paper 1769, p. 41-57, U.S. Geological Survey, Menlo Park, California.

Carver, G.A., and Plafker, George, 2008, Paleoseismicity and neotectonics of the Aleutian subduction zone-An overview, in Freymueller, J.T., Haeussler, P.J., Wesson, R.L, and Ekström, G., eds., Active tectonics and seismic potential of Alaska: American Geophysical Union Monograph 179, p. 43-63.

Christensen, D.H., and Beck, S.L., 1994, The rupture process and tectonic implications of the Great 1964 Prince William Sound Earthquake: Pure and Applied Geophysics, v. 142, no. 1, p. 29-53. http://doi.org/10.1007/BF00875967

Cossart, E., Braucher, R., Fort, M., Bourlès, D.L., and Carcaillet, J., 2008, Slope instability in relation to glacial debuttressing in alpine areas (Upper Durance catchment, southeastern France): Evidence from field data and $10 \mathrm{Be}$ cosmic ray exposure ages: Geomorphology, v. 95, no. 1-2, p. 3-26. https://doi.org/10.1016/j. geomorph.2006.12.022

Coulter, H.W., and Migliaccio, R.R., 1966, Effects of the earthquake of March 27, 1964 at Valdez, Alaska:U.S. Geological Survey Professional Paper, 542-C, 36 p. https://pubs.usgs. gov/ $\mathrm{pp} / 0542 \mathrm{cl}$

Dunbar, P.K., and Weaver, C.S., 2008, U.S. states and territories national tsunami hazard assessment-Historical record and sources for waves: Technical Report, National Oceanic and Atmospheric Administration and U.S. Geological Survey, 59 p. http://nthmp.tsunami. gov/documents/Tsunami_Assessment_Final. pdf

Fine, I. V., Rabinovich, A.B., Kulikov, E.A., Thomson, R.E., and Bornhold, B.D., 1998, Numerical modeling of landslide-generated tsunamis with application to the Skagway Harbor tsunami of November 3, 1994, in Proceedings of the International Conference on Tsunamis: Paris, p. 211-223. 
Freymueller, J.T., Woodard, H., Cohen, S., Cross, R., Elliott, H., Larsen, C., Hreinsdottir, S., and (Geophys. Monogr. Ser., 179, C. Zweck), Active deformation processes in Alaska, based on 15 years of GPS measurements, in Active Tectonics and Seismic Potential of Alaska, Geophys. Monogr. Ser., edited by J. T. Freymueller, P. J. Haeussler, R. Wesson, and G. Ekstrom, AGU, Washington, D. C., p. 1-42.

Geist, E.L., and Lynett, P., 2014, Source processes for the probabilistic assessment of tsunami hazards: Oceanography, v. 27, no. 2, p. 86-93. http://doi.org/10.5670/oceanog.2014.43

Geist, E.L., and Parsons, T., 2006, Probabilistic analysis of tsunami hazards: Natural Hazards. v. 37, no. 3, p. 277-314. http://dx.doi. org/10.1007/s11069-005-4646-z

Grilli, S.T., O’Reilly, C., and Tajalli Bakhsh, T., 2013, Modeling of SMF tsunami generation and regional impact along the upper U.S. East Coast: Center for Applied Coastal Research, University of Delaware, Research Report No. CACR-13-05. http://www1.udel.edu/kirby/ nthmp/reports/grilli-etal-cacr-13-05.pdf

Haeussler, P.J., Lee, H.J., Ryan, H.F., Labay, K.A., Kayen, R.E., Hampton, M.A., and Suleimani, E.N., 2007, Submarine slope failures near Seward, Alaska, during the M9.2 1964 earthquake, in Lykousis, V., Sakellariou, D., and Locat, J., eds., Submarine mass movements and their consequences: Springer, p. 269-278.

Hampton, M.A., Lemke, R.W., and Coulter, H.W., 2002, Submarine landslides that had a significant impact on man and his activities, Seward and Valdez, Alaska, in Schwab, W.C., Lee, H.J., and Twichell, D.C., eds., Submarine Landslides-Selected Studies in the U.S. Exclusive Economic Zone: U.S.G.S. Bulletin 2002, p. 123-134. https://pubs. er.usgs.gov/ publication/b2002

Hare, R., Eakins, B.W., Amante, C., and Taylor, L.A., 2011, Modeling bathymetric uncertainty: US HYDRO 2011 conference, Tampa, FL, April 25-28, 2011, Proceedings. http:// ushydro.thsoa.org/us1 papers.htm
Hayes, G.P., Wald, D.J., and Johnson, R.L., 2012, Slab1.0: A three-dimensional model of global subduction zone geometries: Journal of Geophysical Research, v. 117, no. B01, p. 302. http://doi.org/10.1029/2011JB008524

Holdahl, S.R., and Sauber, Jeanne, 1994, Coseismic slip in the 1964 Prince William Sound earthquake-A new geodetic inversion: Pure and Applied Geophysics, v. 142, no. 1, p. 55-82. http://doi.org/10.1007/BF00875968

Ichinose, Gene, Somerville, Paul, Thio, H.K., Graves, Robert, and O'Connell, Dan, 2007, Rupture process of the 1964 Prince William Sound, Alaska, earthquake from the combined inversion of seismic, tsunami, and geodetic data: Journal of Geophysical Research, v. 112, no. B07, p. 2,156-2,202. http://doi. org/10.1029/2006JB004728

Ito, Y., Tsuji, T., Osada, Y., Kido, M., Inazu, D., Hayashi, Y., Tsushima, H., Hino, R., and Fujimoto, H., 2011, Frontal wedge deformation near the source region of the 2011 Tohoku-Oki earthquake: Geophysical Research Letters, v. 38, no. 7. http://doi.org/10.1029/2011GL048355

Jiang, L., and LeBlond, P.H., 1992, The coupling of a submarine slide and the surface waves which it generates: Journal of Geophysical Research, v. 97, no. C8, p. 12,731-12,744. http://doi. org/10.1029/92JC00912

Johnson, J.M., Satake, Kenji, Holdahl, S.R., and Sauber, Jeanne, 1996, The 1964 Prince William Sound earthquake-Joint inversion of tsunami waveforms and geodetic data: Journal of Geophysical Research, v. 101, no. B1, p. 523-532. http://doi.org/10.1029/95JB02806

Kachadoorian, Reuben, 1965, Effects of the earthquake of March 27, 1964, at Whittier, Alaska: U.S. Geological Survey Professional Paper 542- B, p. B1-B21, 3 sheets, scale $1: 4,800$.

Kachadoorian, Reuben, and Plafker, George, 1967, Effects of the earthquake of March 27, 1964, on communities of Kodiak Area: U.S. Geological Survey Professional Paper 542-F, 41 p. http://pubs.usgs.gov/pp/0542f/ 
Kachadoorian, Reuben, and Slater, W.H., 1978, Pillar Mountain landslide, Kodiak, Alaska: U.S. Geological Survey Open-File Report 78-217, 21 p., 2 sheets, scale 1 inch $=200$ feet.

Karlstrom, T.N. V., 1964, Quaternary geology of the Kenai Lowland and glacial history of the Cook Inlet region, Alaska: U. S. Geological Survey Professional Paper 443, 69 p., 7 plates. http://pubs.er.usgs.gov/publication/pp 443

Kanamori, Hiroo, 1970, The Alaska earthquake of 1964-Radiation of long-period surface waves and source mechanism: Journal of Geophysical Research, v. 75, no. 26, p. 5,029-5,040. http:// doi.org/10.1029/JB075i026p05029

Kienle, Juergen, Kowalik, Zygmunt, Troshina, Elena, 1996, Propagation and runup of tsunami waves generated by Mt. St. Augustine volcano, Alaska: Science of Tsunami Hazard, v. 14, no. 3, p. 190-206.

Kirby, J.T., Shi, F., Nicolsky, D.J., and Misra, S., 2016, The 27 April 1975 Kitimat, British Columbia submarine landslide tsunami-A comparison of modeling approaches: Landslides, v. 13, no. 6, p. 1,421-1,434. http:// doi.org/10.1007/s10346-016-0682-x

Kirby, Stephen, Scholl, David, von Huene, Roland, and Wells, Ray, 2013, Alaska earthquake source for the SAFRR tsunami scenario, Chapter B, in Ross, S.L., and Jones, L.M., eds., The SAFRR (Science Application for Risk Reduction) Tsunami Scenario: U.S. Geological Survey Open-File Report 2013-1170, 40 p.

Kulikov, E.A., Rabinovich, A.B., Fine, I.V., Bornhold, B.D., and Thomson, R.E., 1998, Tsunami generation by landslides at the Pacific coast of North America and the role of tides: Oceanology, v. 38, no. 3, p. 323-328.

Lander, J.F., 1996, Tsunamis affecting Alaska, 1737-1996: Boulder, CO, National Oceanic and Atmospheric Administration, National Geophysical Data Center (NGDC), Key to Geophysical Research Documentation, v. 31, 155 p. ftp://ftp.ngdc.noaa.gov/hazards/ publications/Kgrd-31.pdf

Lee, H.J., Ryan, Holly, Kayen, R.E., Haeussler, P.J., Dartnell, Peter, and Hampton, M.A., 2006,
Varieties of submarine failure morphologies of seismically-induced landslides in Alaskan fjords: Norwegian Journal of Geology (Norsk Geologisk Tidsskrift), v. 86, no. 3, p. 221-230. Lemke, R.W., 1967, Effects of the earthquake of March 27, 1964, at Seward, Alaska: U.S. Geological Survey Professional Paper 542-E, 43 p., 2 sheets, scale 1:63,360.

Lim, E., Eakins, B.W., and Wigley, R., 2009, Southern Alaska coastal relief modelProcedures, data sources, and analysis: National Geophysical Data Center, NOAA, 25 p., http:// www.ngdc.noaa.gov/mgg/coastal/s_alaska.html Lopez-Venegas, A.M., Horrillo, J., Pampell-Manis, A., Huerfano, V., and Mercado, A., 2014, Advanced tsunami numerical simulations of the Puerto Rico October 11, 1918, Mona Passage tsunami: Pure and Applied Geophysics, v. 172, no. 6, p. 1,679-1,698. http://doi.org/10.1007/ s00024-014-0988-3

Løvholt, F., Pedersen, G., Harbitz, C.B., Glimsdal, S., and Kim, J., 2015, On the characteristics of landslide tsunamis: Philosophical Transactions of the Royal Society A, v. 373, no. 2053. http:// doi.org/10.1098/rsta.2014.0376

Ma, G., Shi, F., and Kirby, J.T., 2012, Shockcapturing non-hydrostatic model for fully dispersive surface wave processes: Ocean Modelling, v. 43-44, p. 22-35. http://doi. org/10.1016/j.ocemod.2011.12.002

Miller, D.J., 1960, The Alaska earthquake of July 10, 1958: Giant wave in Lituya Bay: Bulletin of the Seismological Society of America, v. 50, no. 2, p. 253-266.

Moss, R. E. S., and Travasarou, Thaleia, 2006, Tsunamigenic probabilistic fault displacement hazard analysis for subduction zonesProceedings of the 8th U.S. National Conference on Earthquake Engineering: Earthquake Engineering Research Institute, Paper 238, 9 p. National Centers for Environmental Information (NCEI/WDS), in progress, Global historical tsunami database at NCEI, $2100 \mathrm{BC}$ to present (interactive map): National Centers for Environmental Information, NOAA, http:// doi.org/10.7289/V5PN93H7 
National Tsunami Hazard Mapping Program (NTHMP), 2010, Guidelines and best practices for tsunami inundation modeling for evacuation planning: National Oceanic and Atmospheric Administration (NOAA), NTHMP Mapping \& Modeling Subcommittee.

National Tsunami Hazard Mapping Program (NTHMP), 2012, Proceedings and results of the 2011 NTHMP Model Benchmarking Workshop: Boulder, CO, U.S. Department of Commerce/NOAA/NTHMP, NOAA Special Report, 436 p. http://nthmp.tsunami.gov

Nicolsky, D.J., 2012, Alaska tsunami model, in Proceedings and Results of the 2011 NTHMP Model Benchmarking Workshop: Boulder, CO, U.S. Department of Commerce/NOAA/ NTHMP, NOAA Special Report, p. 55-87, http://nthmp.tsunami.gov

Nicolsky, D.J., Suleimani, E.N., Combellick, R.A., and Hansen, R.A., 2011, Tsunami inundation maps of Whittier and western Passage Canal, Alaska: Alaska Division of Geological \& Geophysical Surveys Report of Investigation 2011-7, 65 p. http://doi.org/10.14509/23244

Nicolsky, D.J., Suleimani, E.N., Freymueller, J.T., and Koehler, R.D., 2015, Tsunami inundation maps of Fox Islands communities, including Dutch Harbor and Akutan, Alaska: Alaska Division of Geological \& Geophysical Surveys Report of Investigation 2015-5, 67 p., 2 sheets, scale 1:12,500. http://doi.org/10.14509/29414

Nicolsky, D.J., Suleimani, E.N., Haeussler, P.J., Ryan, H.F., Koehler, R.D., Combellick, R.A., and Hansen, R.A., 2013, Tsunami inundation maps of Port Valdez, Alaska: Alaska Division of Geological \& Geophysical Surveys Report of Investigation 2013-1, 77 p., 1 sheet, scale 1:12,500. http://doi.org/10.14509/25055

Nicolsky, D.J., Suleimani, E.N., and Hansen, R.A., 2011 b, Validation and verification of a numerical model for tsunami propagation and runup: Pure and Applied Geophysics, v. 168, no. 6, p. 1,199-1,222. http://doi.org/10.1007/s00024010-0231-9

Nicolsky, D.J., Suleimani, E.N., and Koehler, R.D.,
2014, Tsunami inundation maps of Cordova and Tatitlek, Alaska: Alaska Division of Geological \& Geophysical Surveys Report of Investigation 2014-1, 49 p. http://doi.org/10.14509/27241 2016, Tsunami inundation maps for the communities of Chignik and Chignik Lagoon, Alaska: Alaska Division of Geological \& Geophysical Surveys Report of Investigation 2016-8, 48 p., 2 sheets, scale 1:12,500. http:// doi.org/10.14509/29675

Nicolsky, D.J., Suleimani, E.N., Koehler, R.D., and Salisbury, J.B., 2017, Tsunami inundation maps for Juneau, Alaska: Alaska Division of Geological \& Geophysical Surveys Report of Investigation 2017-9, 66 p., 5 sheets. http://doi. org/10.14509/29741

Nishenko, S.P., 1991, Circum-Pacific seismic potential, 1989-1999: Pure and Applied Geophysics, v. 135, no. 2, p. 169-259. http:// doi.org/10.1007/BF00880240

Nishenko, S.P., and Jacob, K.H., 1990, Seismic potential of the Queen Charlotte-AlaskaAleutian seismic zone: Journal of Geophysical Research, v. 95, no. B3, p. 2,511-2,532. http:// doi.org/10.1029/JB095iB03p02511

Okada, Y., 1985, Surface deformation due to shear and tensile faults in a half-space: Bulletin of the Seismological Society of America, v. 75, no. 4, p. 1,135-1,154.

Papazachos, B.C., Scordilis, E.M., Panagiotopoulos, D.G., Papazachos, C.B., and Karakaisis, G.F., 2005, Global relations between seismic fault parameters and moment magnitude of earthquakes: Bulletin of the Geological Society of Greece, v. 36, p. 1,482-1,489.

Plafker, George, 1967, Surface faults on Montague Island associated with the 1964 Alaska earthquake: U.S. Geological Survey Professional Paper 543-G, p. G1-G42. http://pubs.usgs.gov/ $\mathrm{pp} / 0543 \mathrm{~g} /$

Plafker, George, 1969, Tectonics of the March 27, 1964, Alaska earthquake: U.S. Geological Survey Professional Paper 543-I, p. I1-I74, 2 sheets. 
Plafker, George, and Kachadoorian, Reuben, 1966, Geologic effects of the March 1964 earthquake and associated seismic sea waves on Kodiak and nearby islands, Alaska: U.S. Geological Survey Professional Paper 543-D, 46 p. http://pubs. usgs.gov/pp/0543d/

Plafker, George, Kachadoorian, Reuben, Eckel, E.B., and Mayo, L.R., 1969, Effects of the earthquake of March 27, 1964, on various communities: U.S. Geological Survey Professional Paper 542-G, 43 p., 2 sheets, scales 1:2,500,000 and 1:250,000. http://pubs.usgs. gov/pp/0542g/

Reger, R.D., Sturmann, A.G., Berg, E.E., and Burns, P.A.C., 2007, A guide to the late Quaternary history of northern and western Kenai Peninsula, Alaska: Alaska Division of Geological \& Geophysical Surveys Guidebook 8, 112 p., 6 sheets, scale 1:63,360. http://doi. org/10.14509/15941

Ross, S.L., and Jones, L.M., eds., 2013, The SAFRR Tsunami Scenario: U.S. Geological Survey Open-File Report 2013-1170, 897 p. http://pubs.usgs.gov/of/2013/1170/

Ryan, H., von Huene, R., Scholl, D., and Kirby, S., 2012, Tsunami hazards to US coasts from giant earthquakes in Alaska: Eos Transactions, American Geophysical Union, v. 93, no. 19, 185 p. http://doi. org/10.1029/2012EO190001

Schlotfeldt, P., Tart, R. Jr., Panton, B., and Dugan, R., 2014, Pillar Mountain landslide-Failure mechanism update: American Rock Mechanics Association, Proceedings of the 48th U.S. Rock Mechanics/Geomechanics Symposium, June 1-4, 2014.

Schwab, W.C., Lee, H.J., and Twichell, D.C., 1993, Submarine landslides; Selected studies in the U.S. Exclusive Economic Zone: U.S. Geological Survey Bulletin 2002, 204 p. https:// pubs.er.usgs.gov/publication/b2002

Shannon, W.L., and Hilts, D.E., 1973, Earthquakecaused submarine landslide at Seward, Alaska, in The Great Alaska Earthquake of 1964: National Academy of Sciences, Engineering, Publication 1606, p. 144-156.
Shennan, Ian, Barlow, Natasha, Carver, Gary, Davies, Frank, Garrett, Ed, and Hocking, Emma, 2014, Great tsunamigenic earthquakes during the past $1,000 \mathrm{yr}$ on the Alaska megathrust: Geology, v. 42, no. 8, p. 687-690. http://doi.org/10.1130/G35797.1

Shennan, Ian, Bruhn, Ronald, Barlow, Natasha, Good, Kelly, and Hocking, Emma, 2014, Late Holocene great earthquakes in the eastern part of the Aleutian megathrust: Quaternary Science Reviews, v. 84, p. 86-97. http://doi. org/10.1016/j.quascirev.2013.11.010

Stanley, K.W., 1965, Effects of post-earthquake conditions on the Homer Spit, Alaska, in Science in Alaska, 1964: Alaskan Science Conference, 15th, College, Alaska, 1964, p. 89-90.

-1966, Beach changes on Homer spit, in Waller, R.M., Effects of the earthquake of March 27, 1964, in the Homer area, Alaska: U.S. Geological

Survey Professional Paper 542-D, p. D20-D27, 1 sheet, scale 1:2,400.

Suito, Hisashi, and Freymueller, J.T., 2009, A viscoelastic and afterslip postseismic deformation model for the 1964 Alaska earthquake: Journal of Geophysical Research, v. 114, no. B11, p. 404-426. http://doi. org 10.1029/2008JB005954

Suleimani, E.N., 2011, Numerical studies of tectonic and landslide-generated tsunamis caused by the 1964 Great Alaska Earthquake: Fairbanks, Alaska, University of Alaska Fairbanks, Ph.D. dissertation, 181 p.

Suleimani, E.N., Combellick, R.A., Marriott, D., Hansen, R.A., Venturato, A.J., and Newman, J.C., 2005, Tsunami hazard maps of the Homer and Seldovia areas, Alaska: Alaska Division of Geological \& Geophysical Surveys Report of Investigation 2005-2, 28 p., 2 sheets, scale 1:12,500. http://doi.org/10.14509/14474

Suleimani, E.N., Nicolsky, D.J., and Koehler, R.D., 2013, Tsunami inundation maps of Sitka, Alaska: Alaska Division of Geological \& Geophysical Surveys Report of Investigation 2013-3, 76 p., 1 sheet, scale 1:250,000. http:// doi.org/10.14509/26671 
Suleimani, E.N., Nicolsky, D.J., and Koehler, R.D., 2015, Tsunami inundation maps of Elfin Cove, Gustavus, and Hoonah, Alaska: Alaska Division of Geological \& Geophysical Surveys Report of Investigation 2015-1, 79 p. http:// doi.org/10.14509/29404

Suleimani, E.N., Nicolsky, D.J., Koehler, R.D., Freymueller, J.T., and Macpherson, A.E., 2016, Tsunami inundation maps for King Cove and Cold Bay communities, Alaska: Alaska Division of Geological \& Geophysical Surveys Report of Investigation 2016-1, 73 p., 2 sheets, scale 1:12,500. http://doi.org/10.14509/29565

Suleimani, E.N., Nicolsky, D.J., West, D.A., Combellick, R.A., and Hansen, R.A., 2010, Tsunami inundation maps of Seward and northern Resurrection Bay, Alaska: Alaska Division of Geological \& Geophysical Surveys Report of Investigation 2010-1, 47 p., 3 sheets, scale 1:12,500. http://doi.org/10.14509/21001

Synolakis, C.E., Bernard, E.N., Titov, V.V., Kânoğlu, U., and González, F.I., 2007, Standards, criteria, and procedures for NOAA evaluation of tsunami numerical models: Seattle, National Oceanic and Atmospheric Administration (NOAA)/Pacific Marine Environmental Laboratory (PMEL), Technical Memorandum OAR PMEL-135, 55 p. www.pmel.noaa.gov/pubs/PDF/syno3053/ syno3053.pdf

Tehranirad, B., Kirby, J.T., Ma, G., and Shi, F., 2012, Tsunami benchmark results for nonhydrostatic wave model NHWAVE, Version 1.1: Newark, NJ, University of Delaware Center for Applied Coastal Research, Research Report No. CACR-12-03, 43 p.

U.S. Coast and Geodetic Survey, 1964, Prince William Sound, Alaskan earthquakes, MarchApril 1964: U.S. Coast and Geodetic Survey, Seismology Division, Preliminary Report, 83 p. Waller, R.M.,1966, Effects of the earthquake of March 27, 1964 in the Homer Area, Alaska: U.S. Geological Survey Professional Paper 542D, $28 \mathrm{p}$.

Waythomas, C.F., Watts, P., and Walder, J. S., 2006, Numerical simulation of tsunami generation by cold volcanic mass flows at Augustine Volcano, Alaska: Natural Hazards and Earth System Science, v. 6, p. 671-685. https://doi.org/10.5194/nhess-6-671-2006

Wiles, G.C., and Calkin, P.E., 1992, Reconstruction of a debris-slide-initiated flood in the southern Kenai Mountains, Alaska: Geomorphology, v. 5, p. 535-546.

Wilson, B.W., and Tørum, A., 1968, The tsunami of the Alaskan earthquake, 1964-Engineering evaluation: Vicksburg, MI, U.S. Army Corps of Engineers Technical Memorandum No. 25, $401 \mathrm{p}$.

Zweck, C., Freymueller, J.T., Cohen, S.C., 2002, Elastic dislocation modeling of the postseismic response to the 1964 Alaska earthquake, Journal of Geophysical Research, v. 107, no. B4. http:// doi.org/10.1029/2001JB000409

2002, Three-dimensional elastic dislocation modeling of the postseismic response to the 1964 Alaska earthquake, Journal of Geophysical Research, v. 107, n. B4. http:// doi.org/10.1029/2001JB000409 


\section{APPENDIX A}

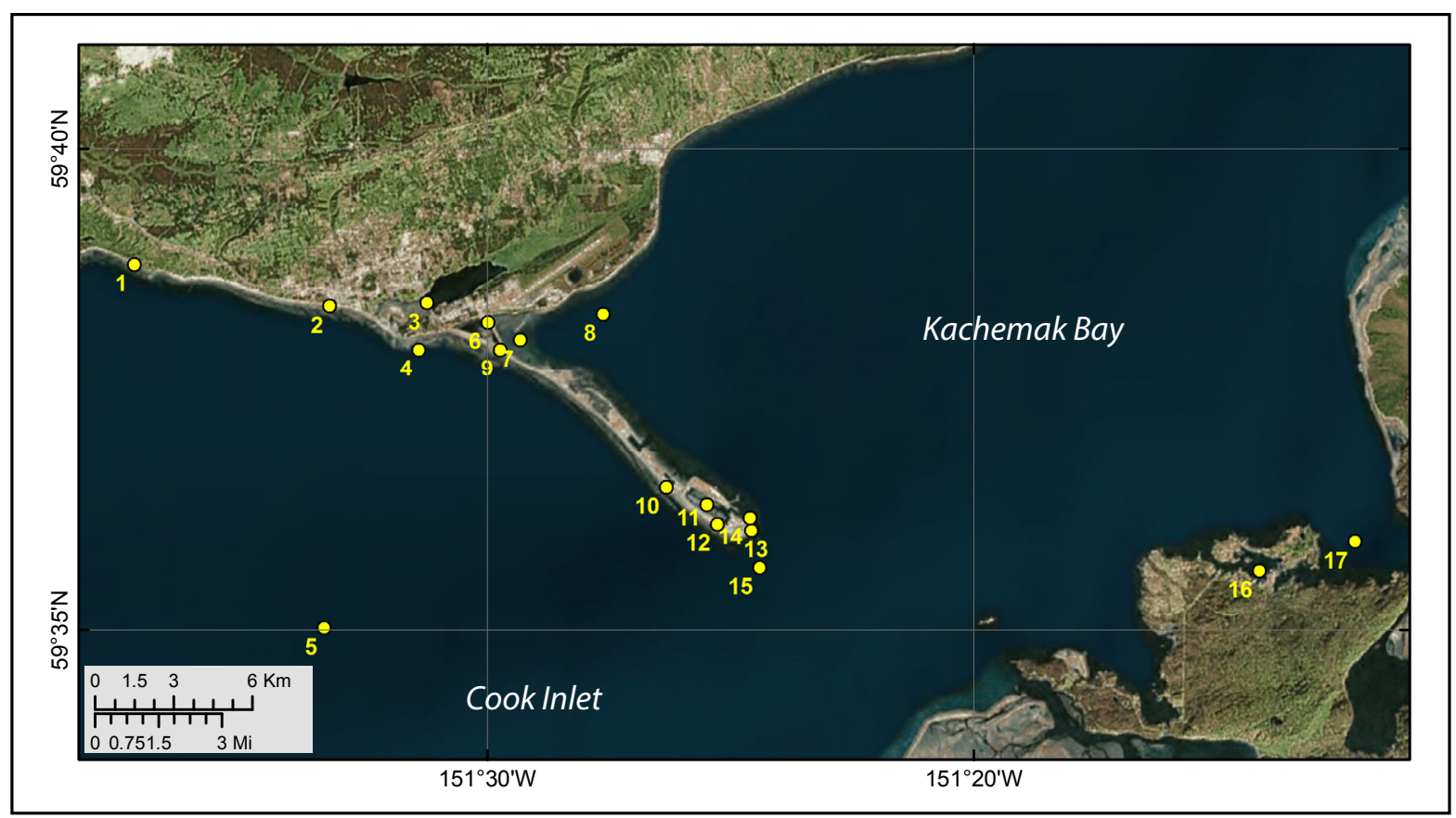

Figure A1. Locations of time series points in Cook Inlet and Kachemak Bay. The longitude and latitude locations of the time series points are listed in tables A1 and A2.

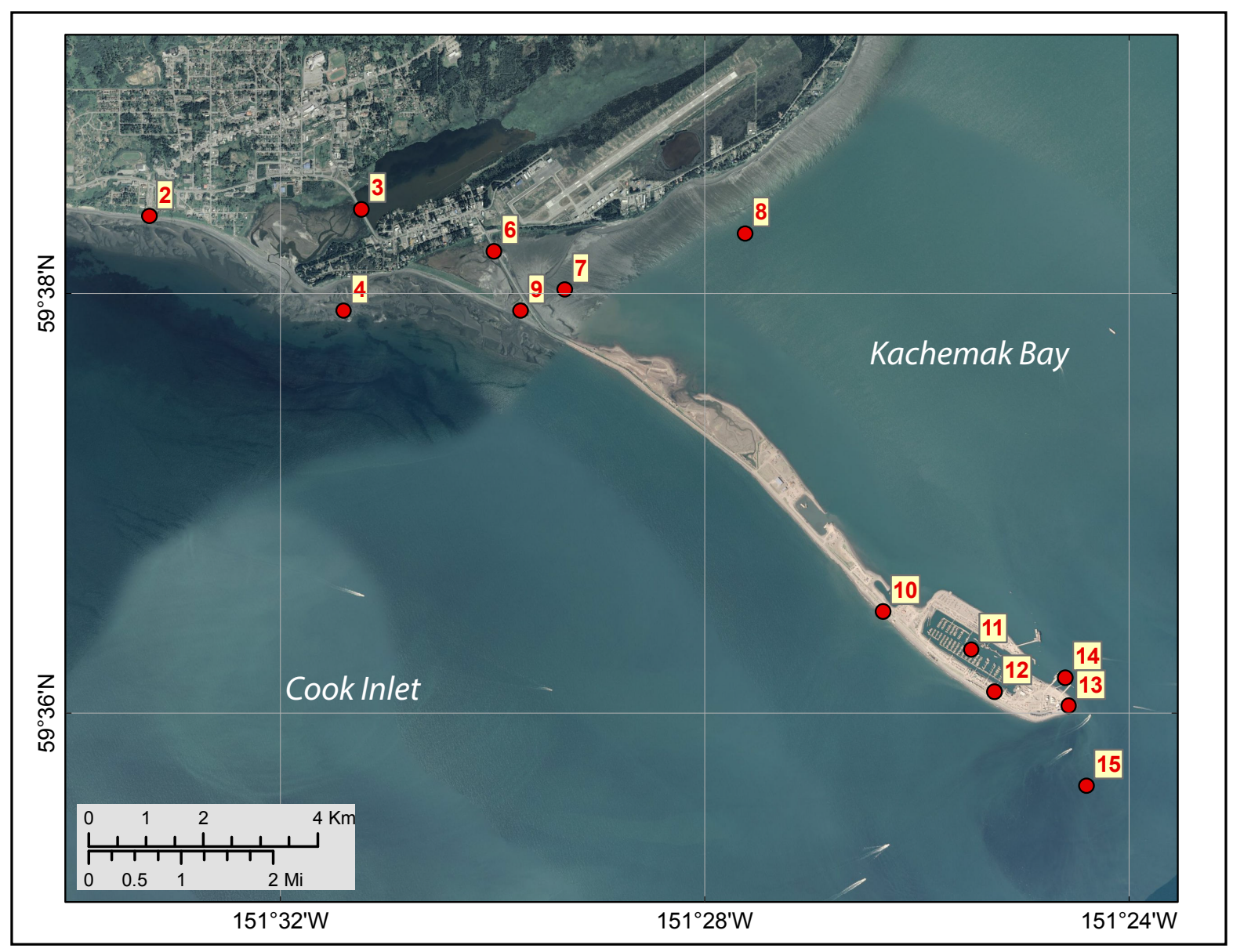

Figure A2. Detail map, locations of time series points near Homer. The longitude and latitude locations of the time series points are listed in tables $\mathrm{A} 1$ and $\mathrm{A} 2$. 
Updated tsunami inundation maps for Homer and Seldovia, Alaska

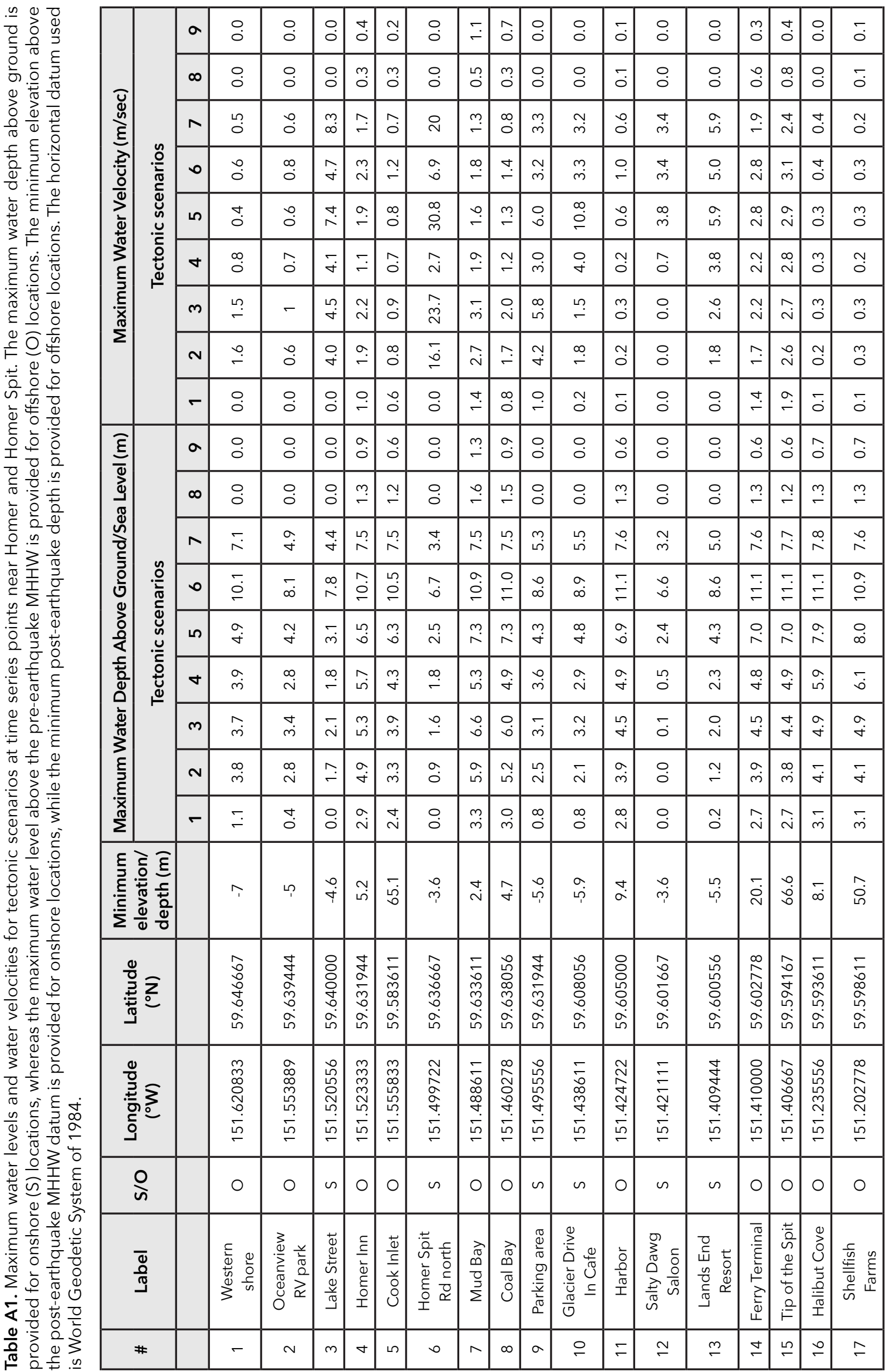


64 Report of Investigation $2018-5$ v. 2

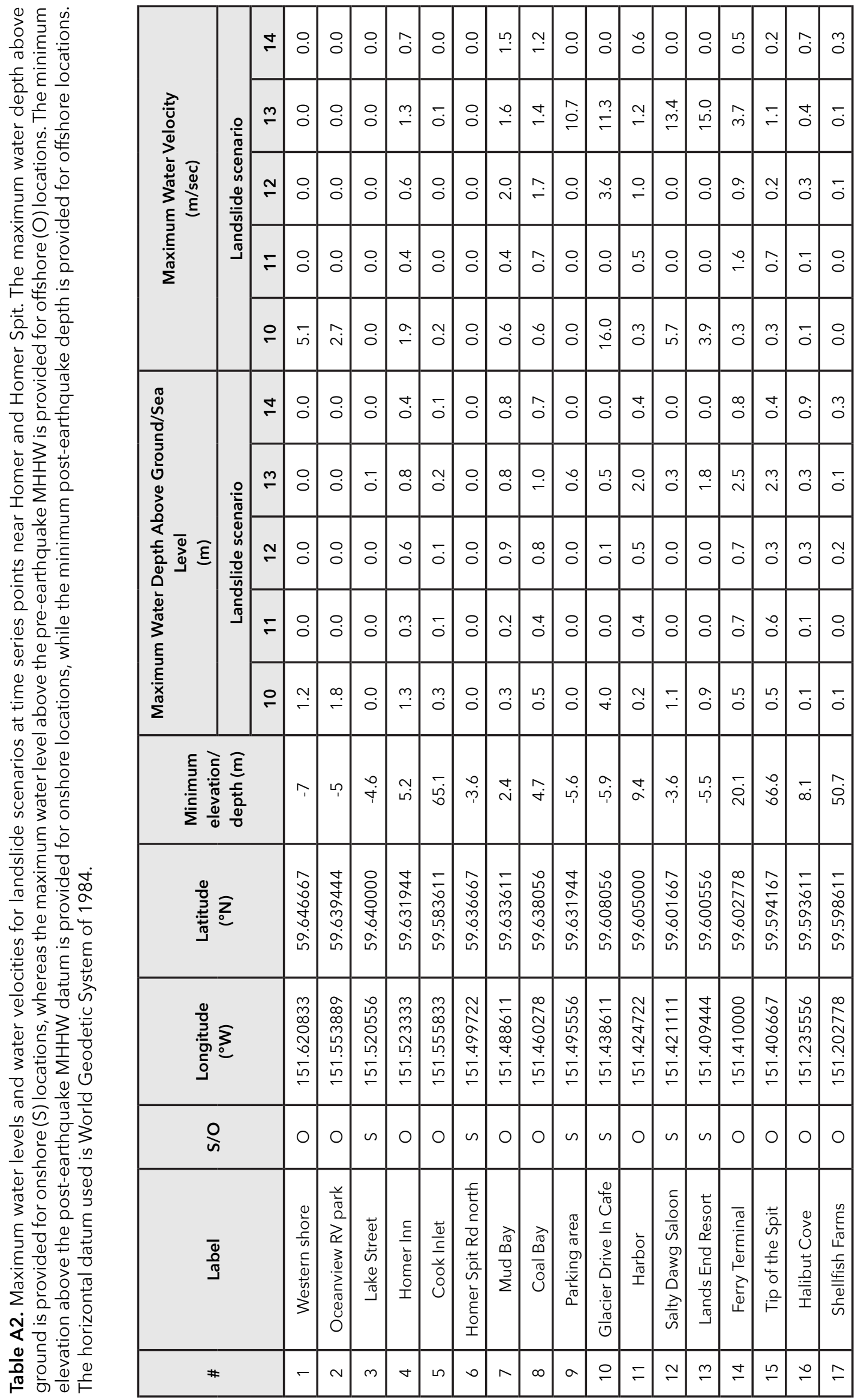




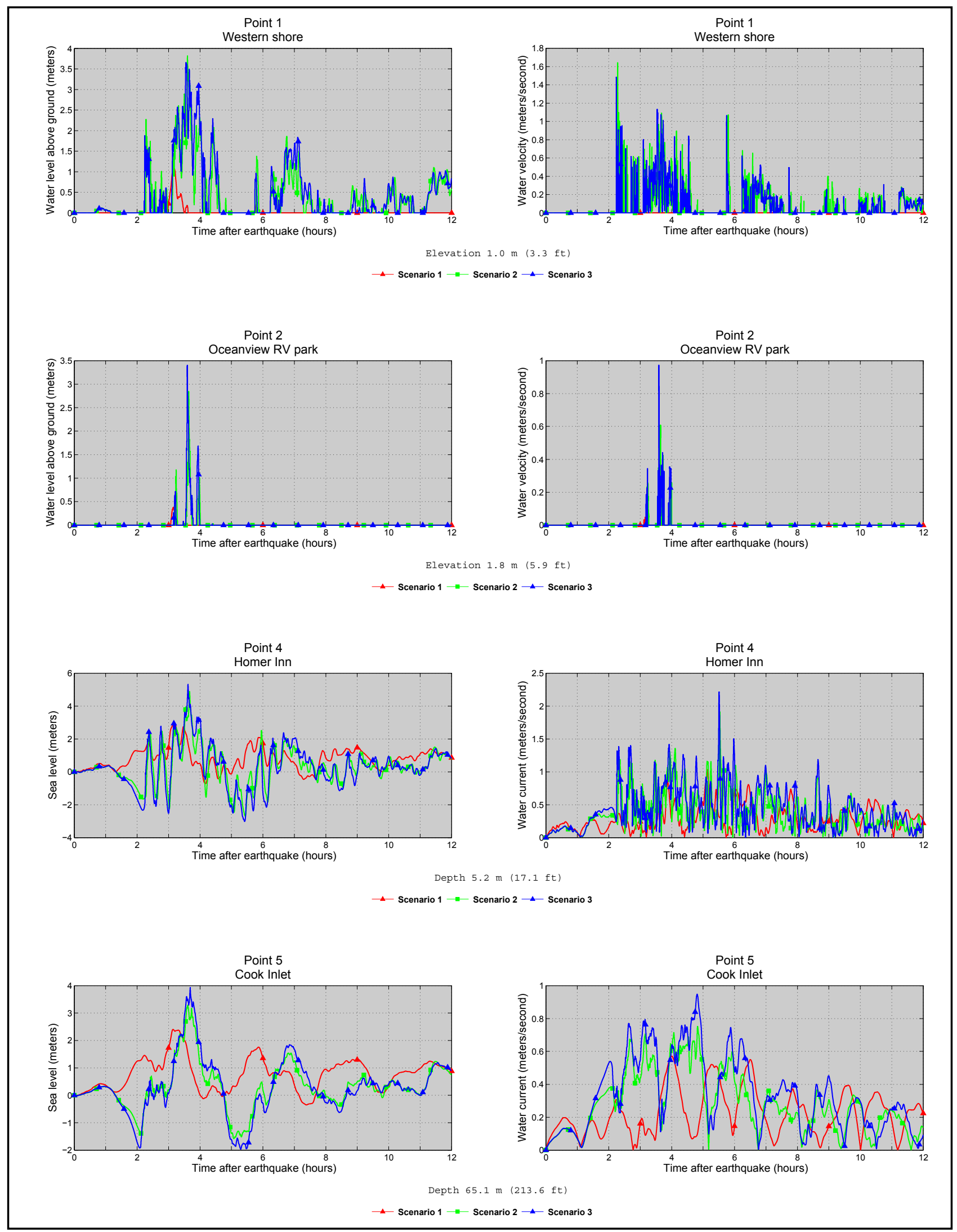

Figure A3. Time series of water level (left column) and velocity (right column) for tectonic scenarios 1-3 at selected locations shown in figures $\mathrm{A} 1$ and $\mathrm{A} 2$. Elevations of onshore locations and ocean depth at offshore locations are given based on the pre-earthquake MHHW datum. 

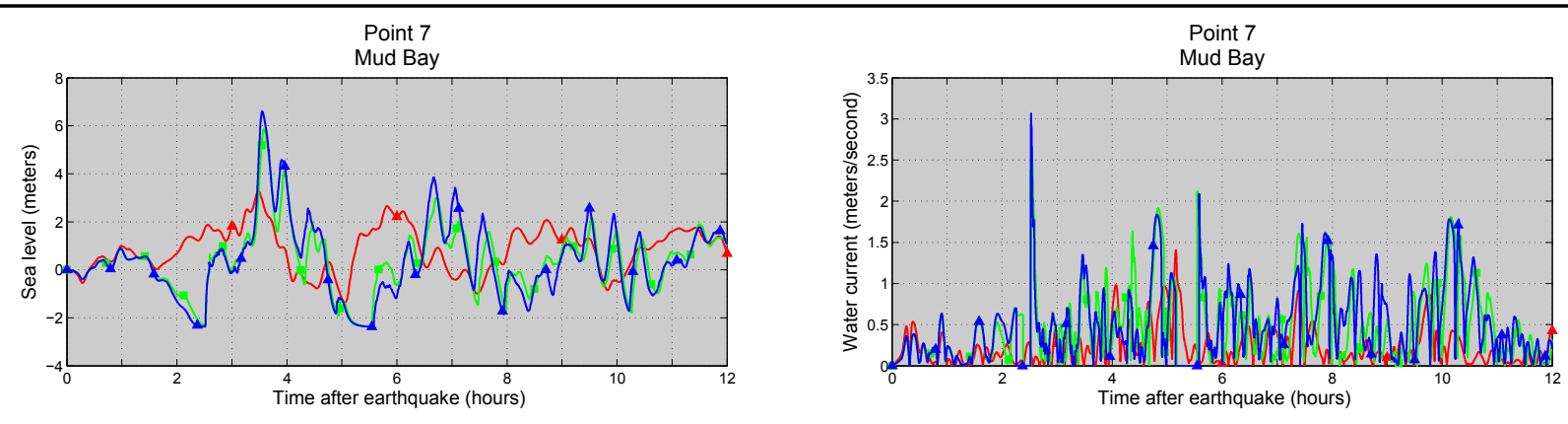

Depth $2.4 \mathrm{~m}(7.9 \mathrm{ft})$

$\triangle$ Scenario $1 \multimap$ Scenario $2 \multimap$ Scenario 3
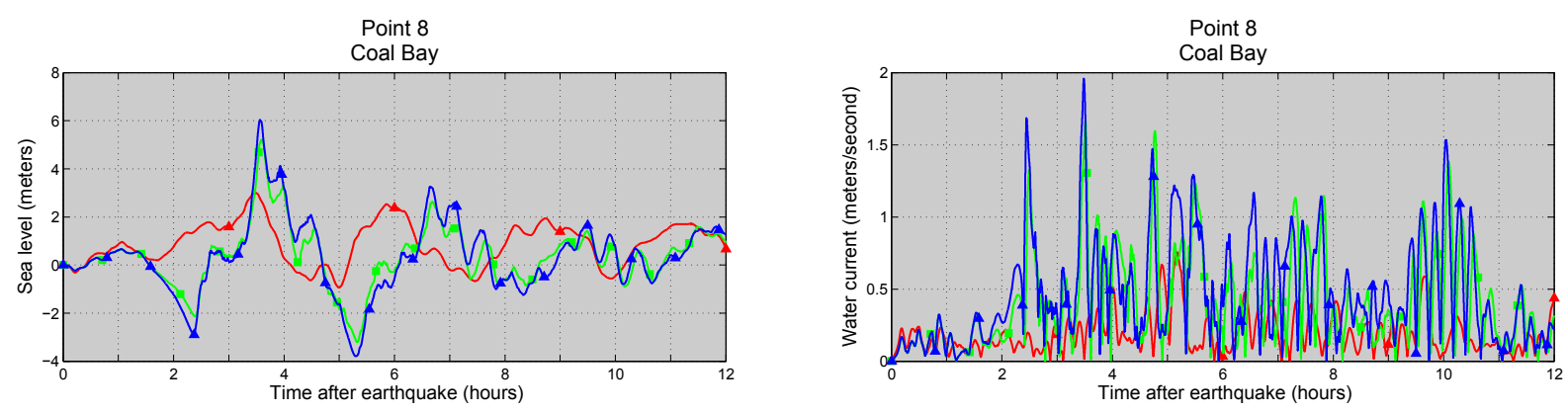

Depth $4.7 \mathrm{~m}(15.3 \mathrm{ft})$

$\neg$ Scenario $1 \longrightarrow$ Scenario $2 \multimap$ Scenario 3
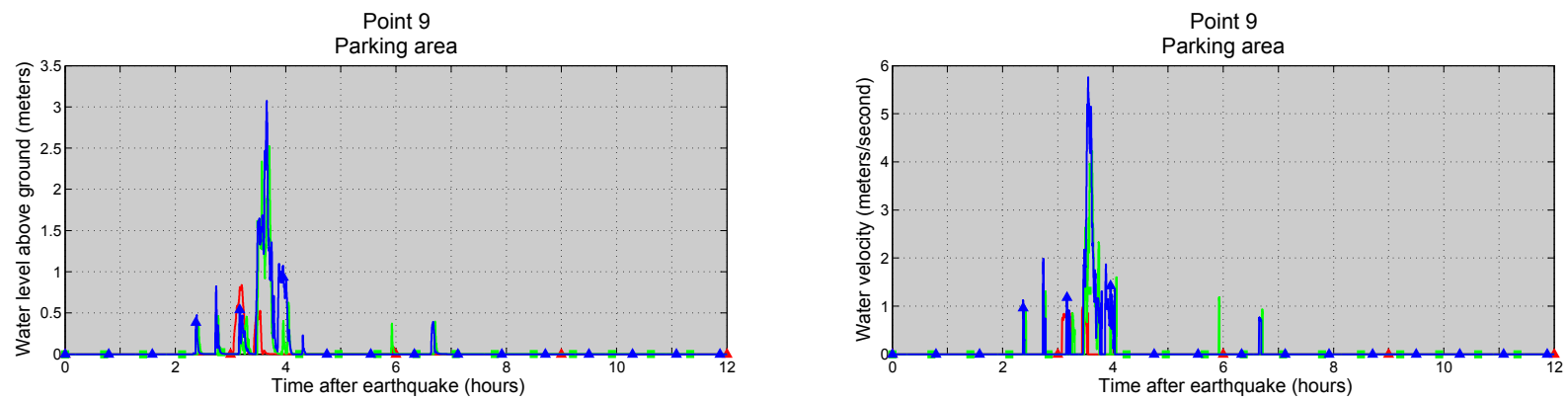

Elevation $1.5 \mathrm{~m}(4.8 \mathrm{ft})$

$\leadsto$ Scenario $1 \rightarrow$ Scenario $2 \rightarrow$ Scenario 3

Point 10

Glacier Drive In Cafe

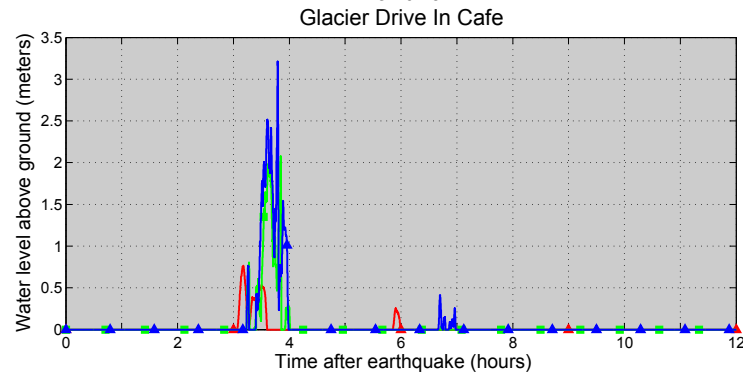

Point 10

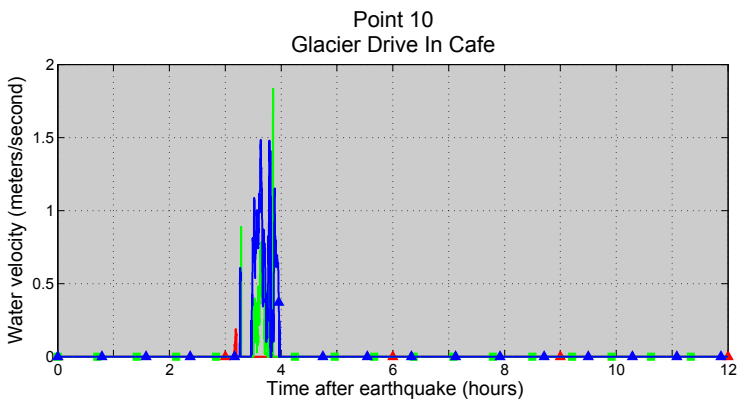

Elevation $1.2 \mathrm{~m}(4.1 \mathrm{ft})$

Figure A3, continued. Time series of water level (left column) and velocity (right column) for tectonic scenarios 1-3 at selected locations shown in figures A1 and A2. Elevations of onshore locations and ocean depth at offshore locations are given based on the pre-earthquake MHHW datum. 


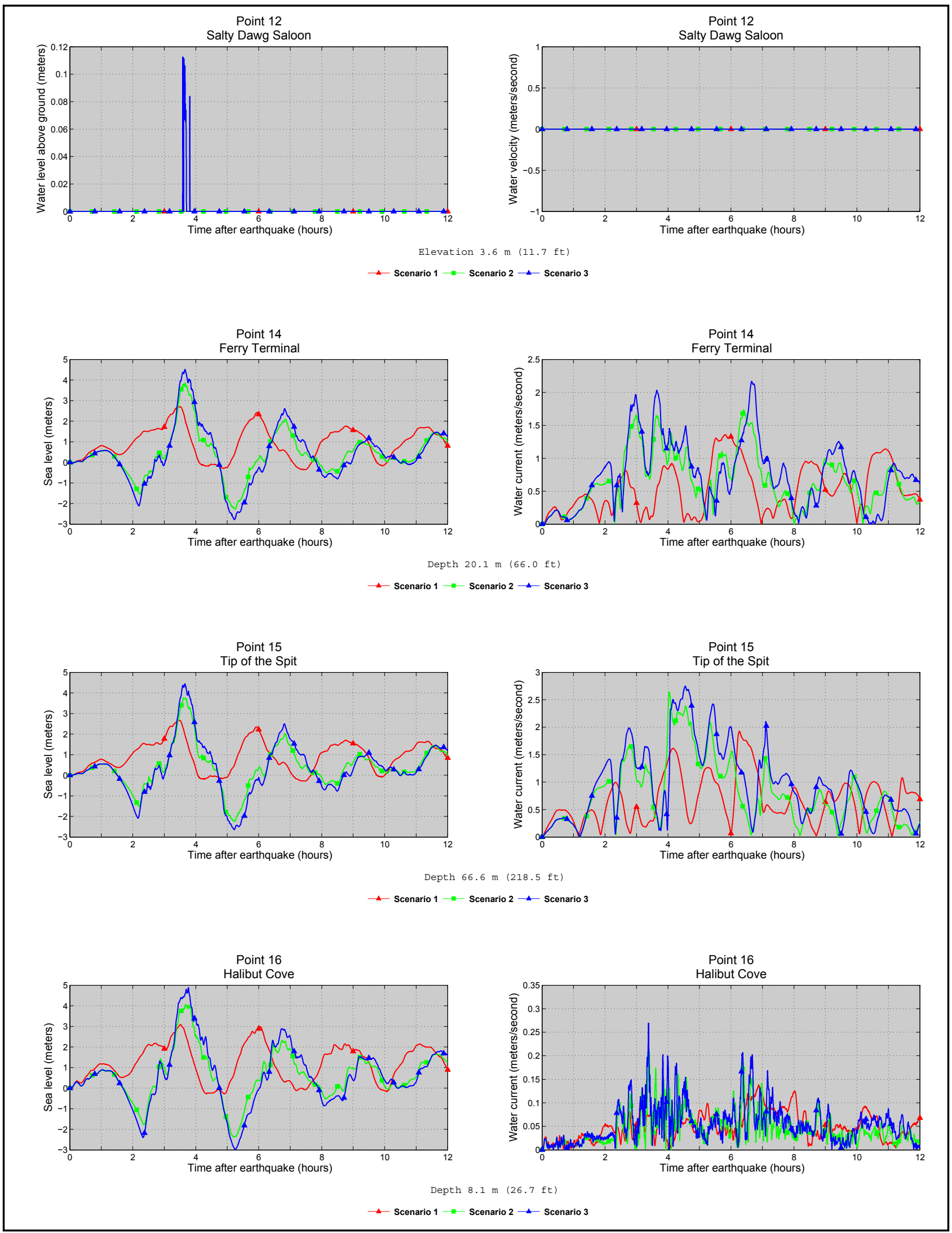

Figure A3, continued. Time series of water level (left column) and velocity (right column) for tectonic scenarios 1-3 at selected locations shown in figures A1 and A2. Elevations of onshore locations and ocean depth at offshore locations are given based on the pre-earthquake MHHW datum. 


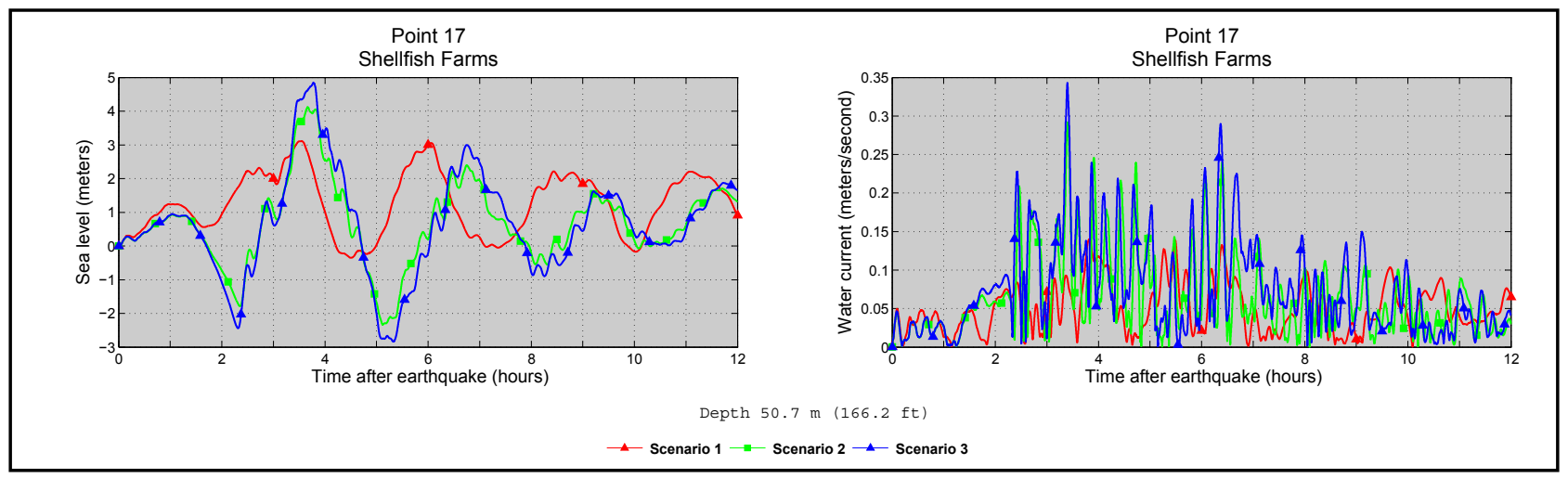

Figure A3, continued. Time series of water level (left column) and velocity (right column) for tectonic scenarios 1-3 at selected locations shown in figures A1 and A2. Elevations of onshore locations and ocean depth at offshore locations are given based on the pre-earthquake MHHW datum. 


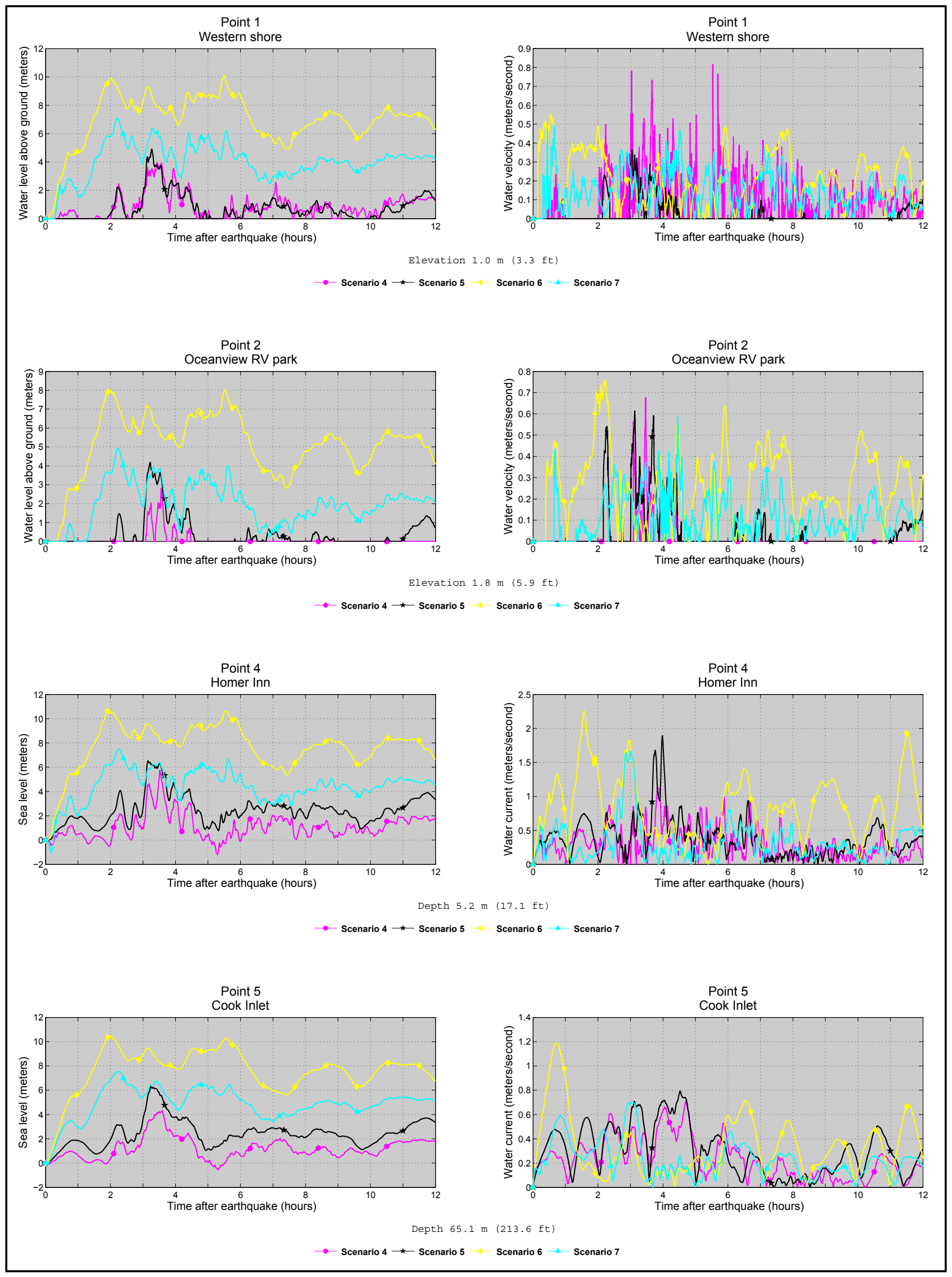

Figure A4. Time series of water level (left column) and velocity (right column) for tectonic scenarios 4-7 at selected locations shown in figures A1 and A2. Elevations of onshore locations and ocean depth at offshore locations are given based on the pre-earthquake MHHW datum. 

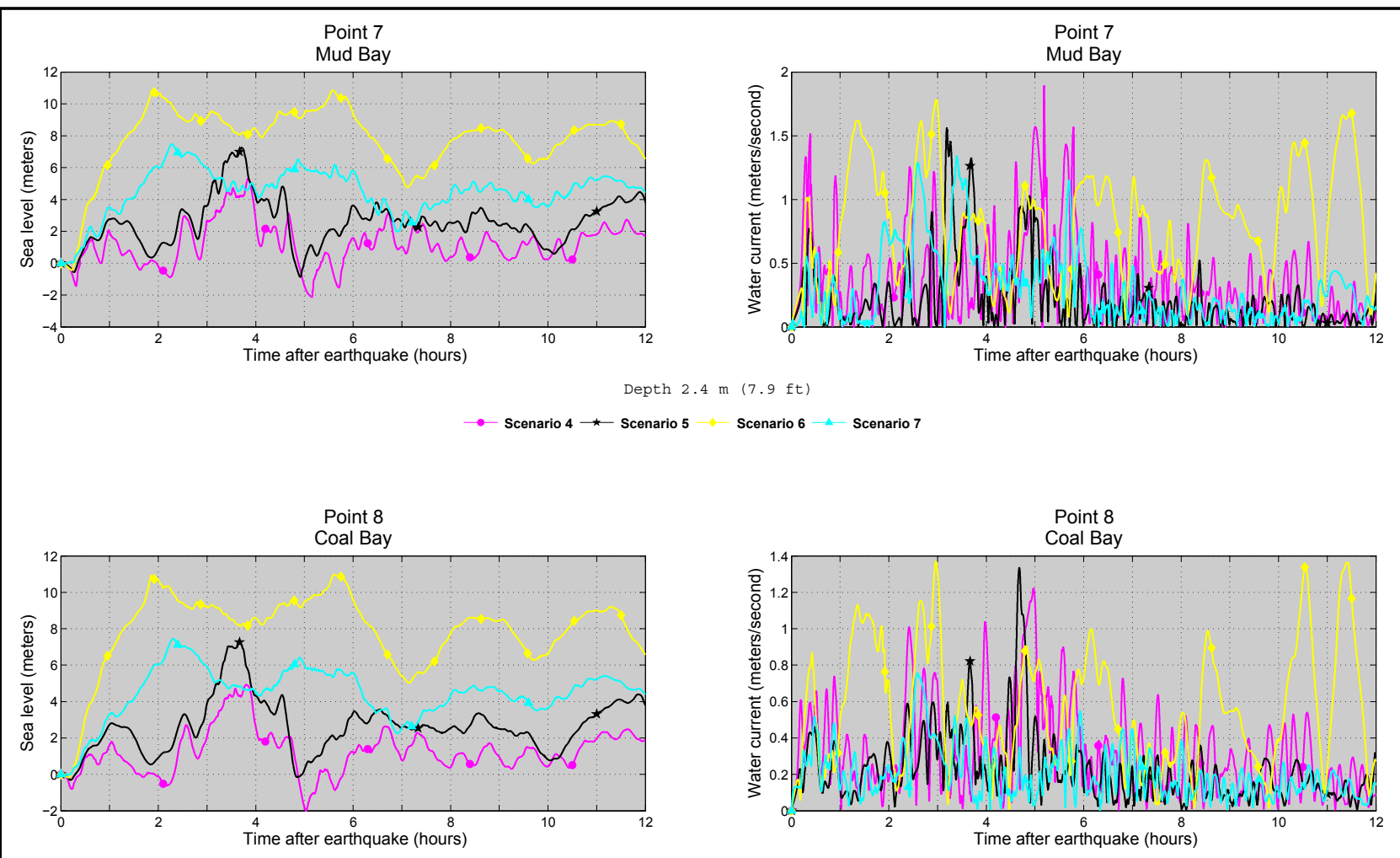

Depth $4.7 \mathrm{~m}(15.3 \mathrm{ft})$

$\rightarrow$ Scenario $4 \rightarrow$ Scenario $5 \longrightarrow$ Scenario $6 \nrightarrow$ Scenario 7
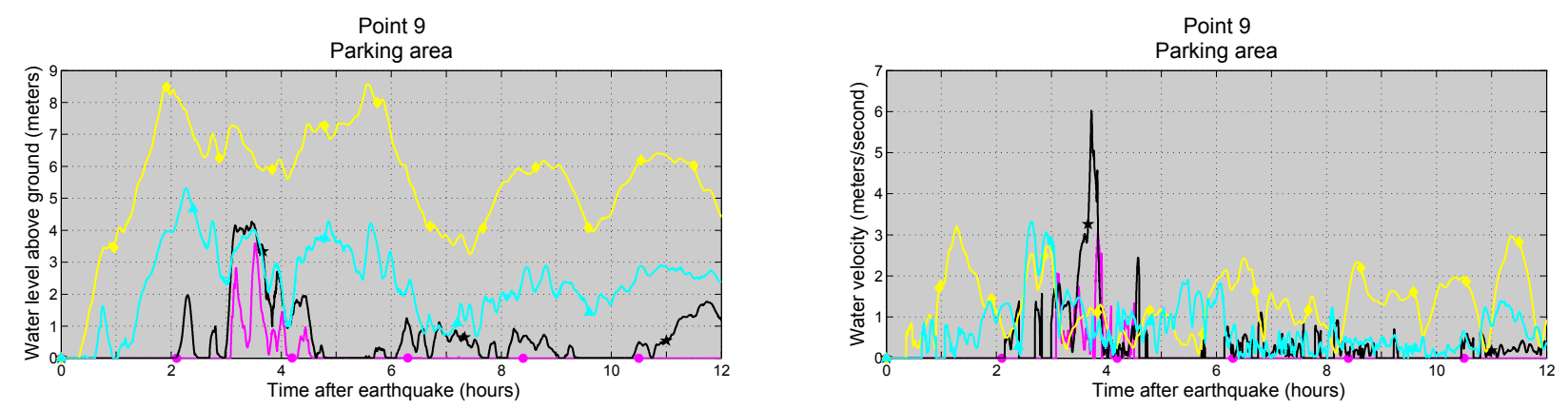

Elevation $1.5 \mathrm{~m}(4.8 \mathrm{ft})$

$\rightarrow$ Scenario $4 \longrightarrow$ Scenario $5 \multimap$ Scenario $6 \multimap$ Scenario 7

Point 10

Glacier Drive In Cafe

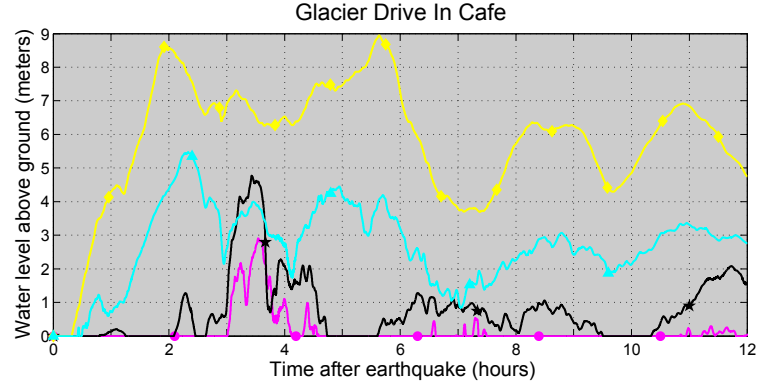

Elevation $1.2 \mathrm{~m}(4.1 \mathrm{ft})$
Point 10

Glacier Drive In Cafe

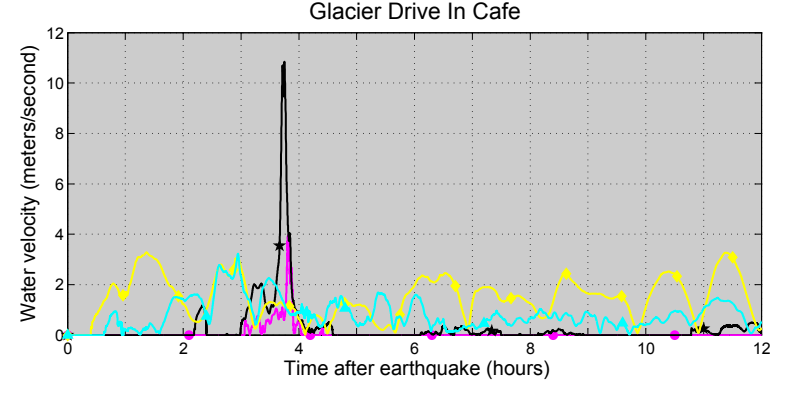

Scenario $6 \multimap$ Scenario 7

Figure A4, continued. Time series of water level (left column) and velocity (right column) for tectonic scenarios 4-7 at selected locations shown in figures A1 and A2. Elevations of onshore locations and ocean depth at offshore locations are given based on the pre-earthquake MHHW datum. 


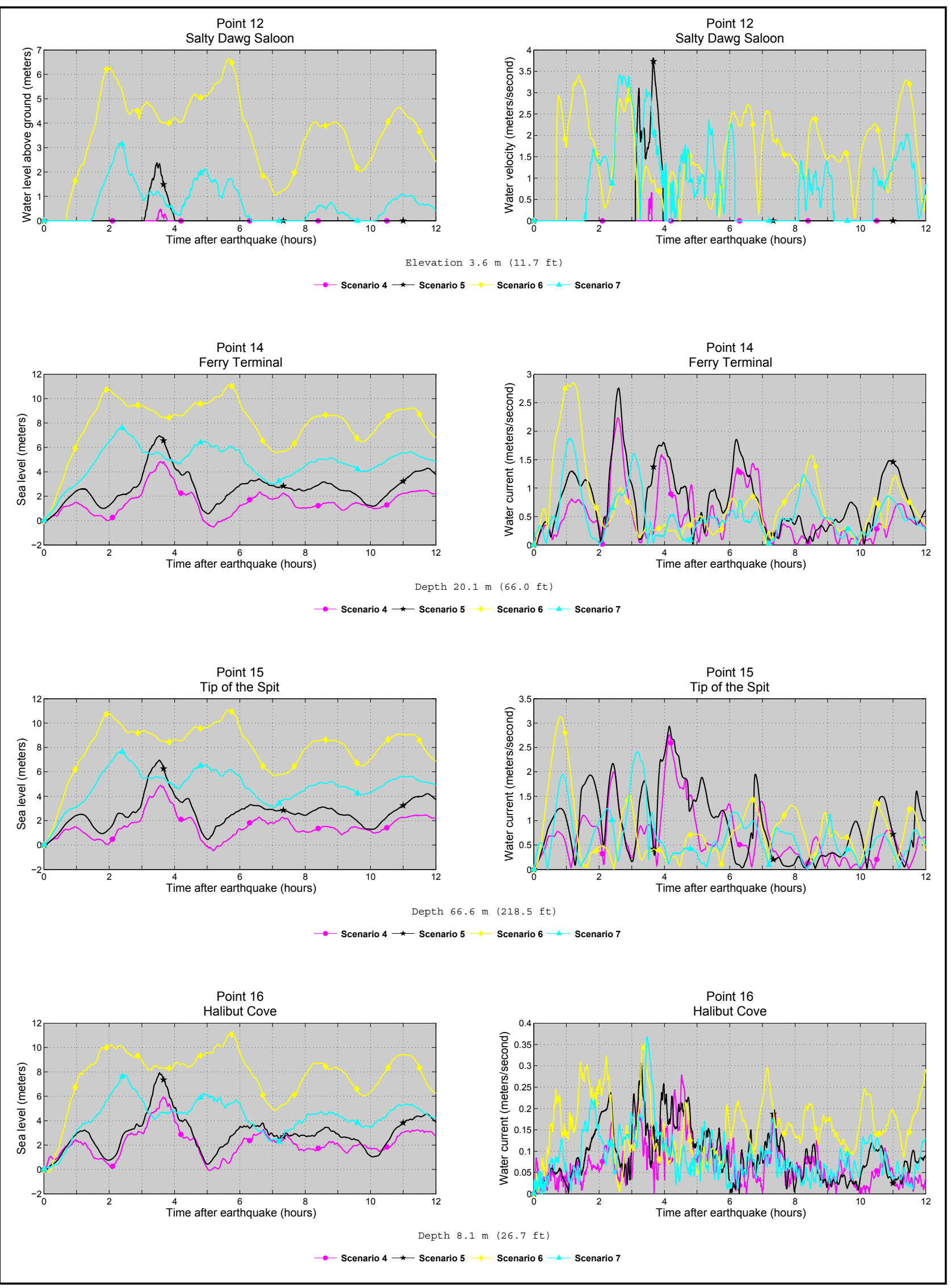

Figure A4, continued. Time series of water level (left column) and velocity (right column) for tectonic scenarios 4-7 at selected locations shown in figures A1 and A2. Elevations of onshore locations and ocean depth at offshore locations are given based on the pre-earthquake MHHW datum. 


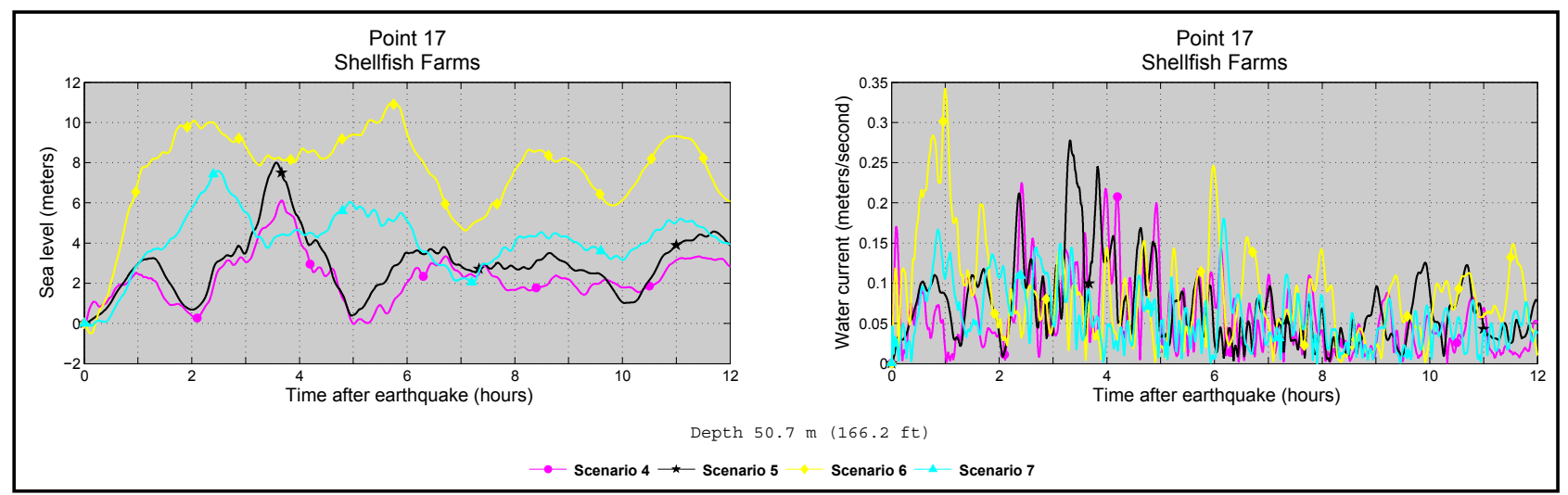

Figure A4, continued. Time series of water level (left column) and velocity (right column) for tectonic scenarios 4-7 at selected locations shown in figures A1 and A2. Elevations of onshore locations and ocean depth at offshore locations are given based on the pre-earthquake MHHW datum. 

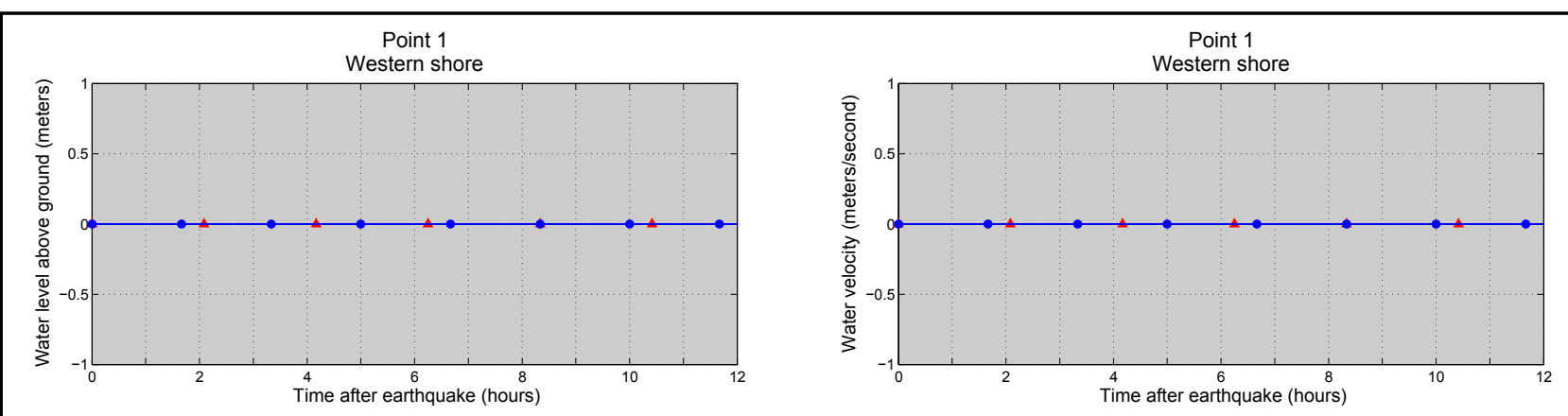

Elevation $1.0 \mathrm{~m}(3.3 \mathrm{ft})$

$\_$Scenario $8 \longrightarrow$ Scenario 9
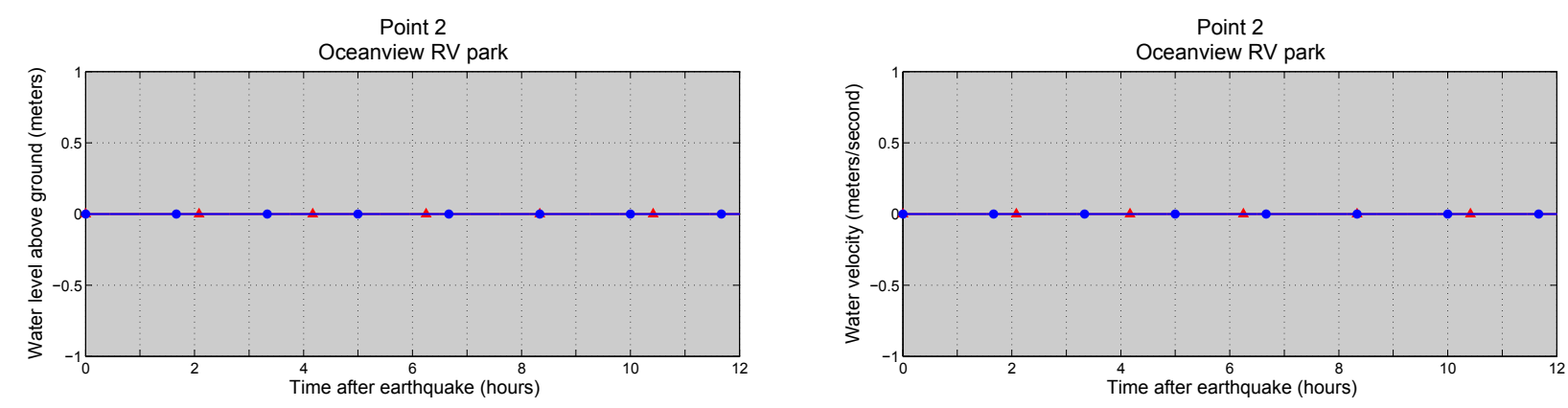

Elevation $1.8 \mathrm{~m}(5.9 \mathrm{ft})$

$\triangle$ Scenario $8 \rightarrow$ Scenario 9
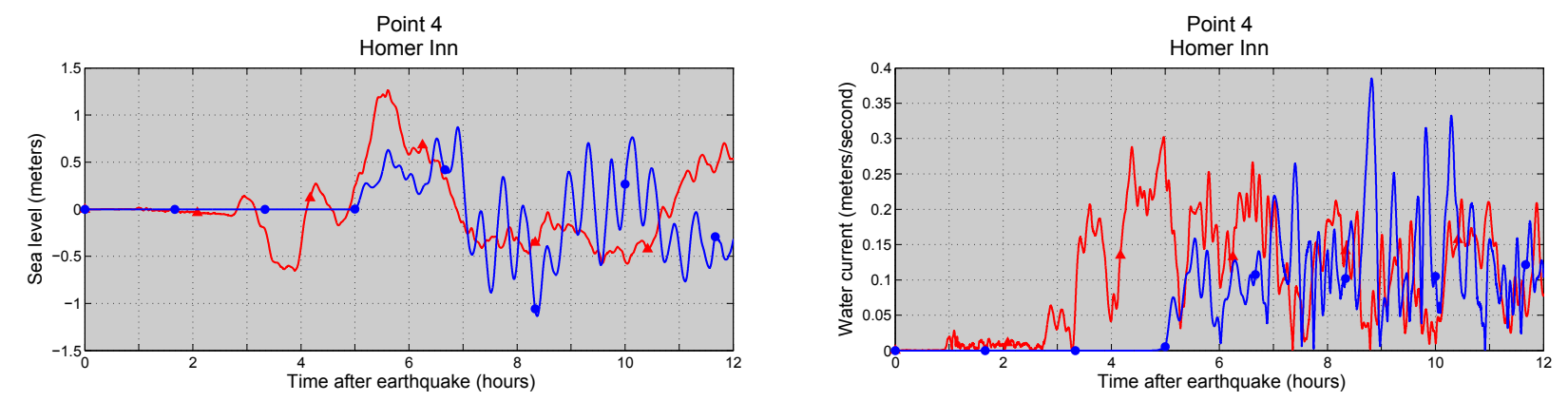

Depth $5.2 \mathrm{~m}(17.1 \mathrm{ft})$

$\rightarrow$ Scenario $8 \rightarrow$ Scenario 9
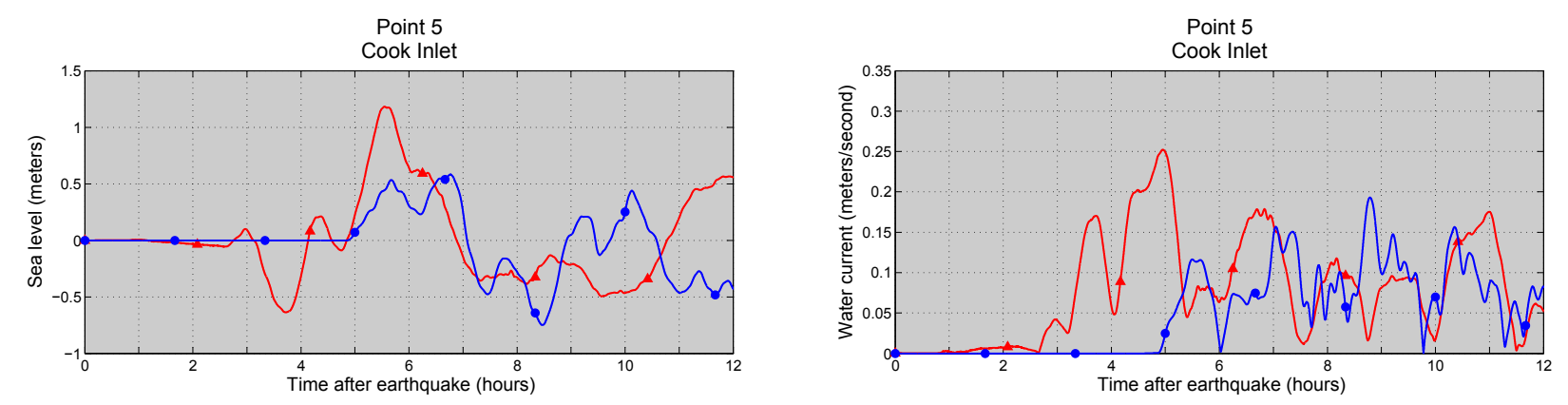

Depth $65.1 \mathrm{~m}(213.6 \mathrm{ft})$

$\multimap$ Scenario $8 \longrightarrow$ Scenario 9

Figure A5. Time series of water level (left column) and velocity (right column) for tectonic scenarios 8-9 at selected locations shown in figures A1 and A2. Elevations of onshore locations and ocean depth at offshore locations are given based on the pre-earthquake MHHW datum. 

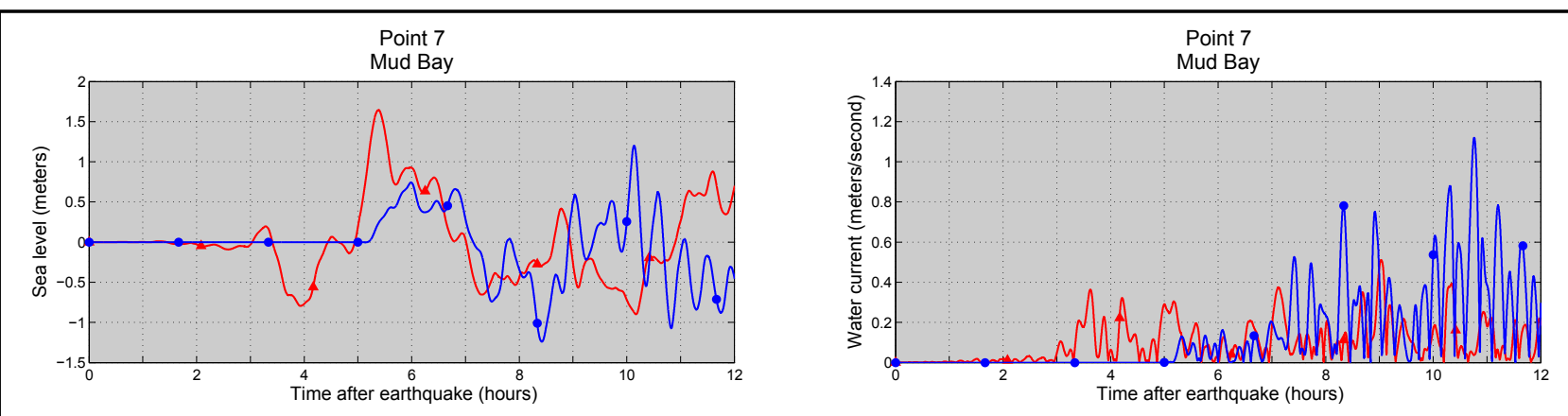

Depth $2.4 \mathrm{~m}(7.9 \mathrm{ft})$

$\longrightarrow$ Scenario $8 \longrightarrow$ Scenario 9
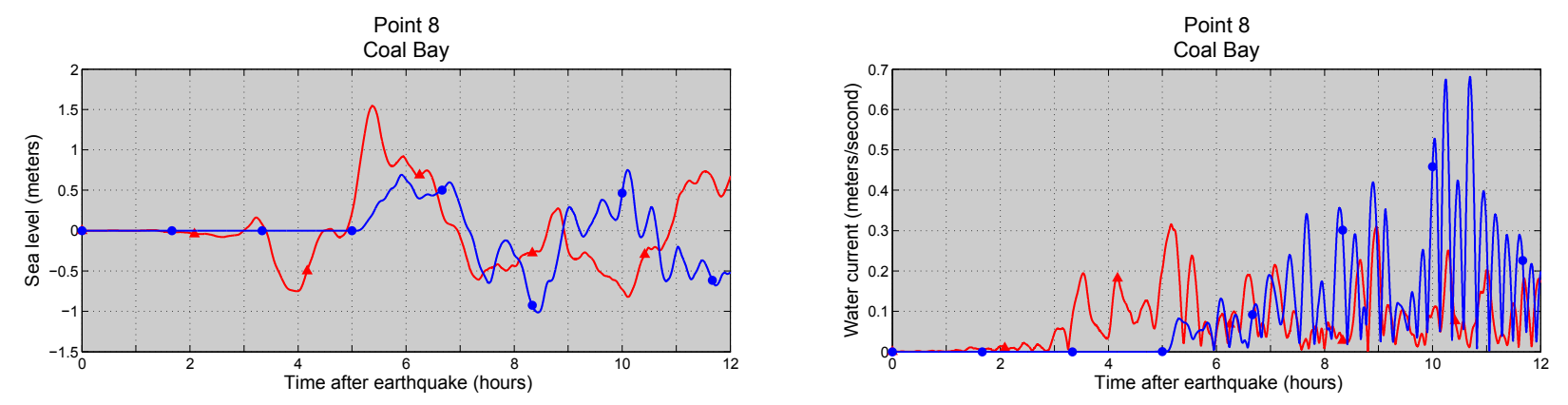

Depth $4.7 \mathrm{~m}$ (15.3 ft)

$\longrightarrow$ Scenario $8 \longrightarrow$ Scenario 9
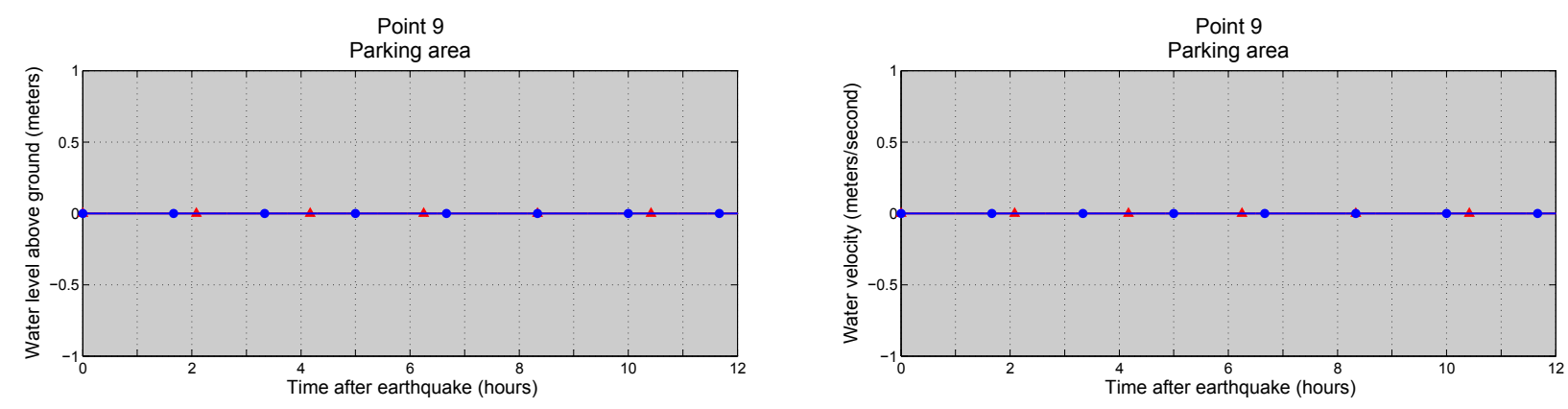

Elevation $1.5 \mathrm{~m}(4.8 \mathrm{ft})$

$\longrightarrow$ Scenario $8 \rightarrow$ Scenario 9
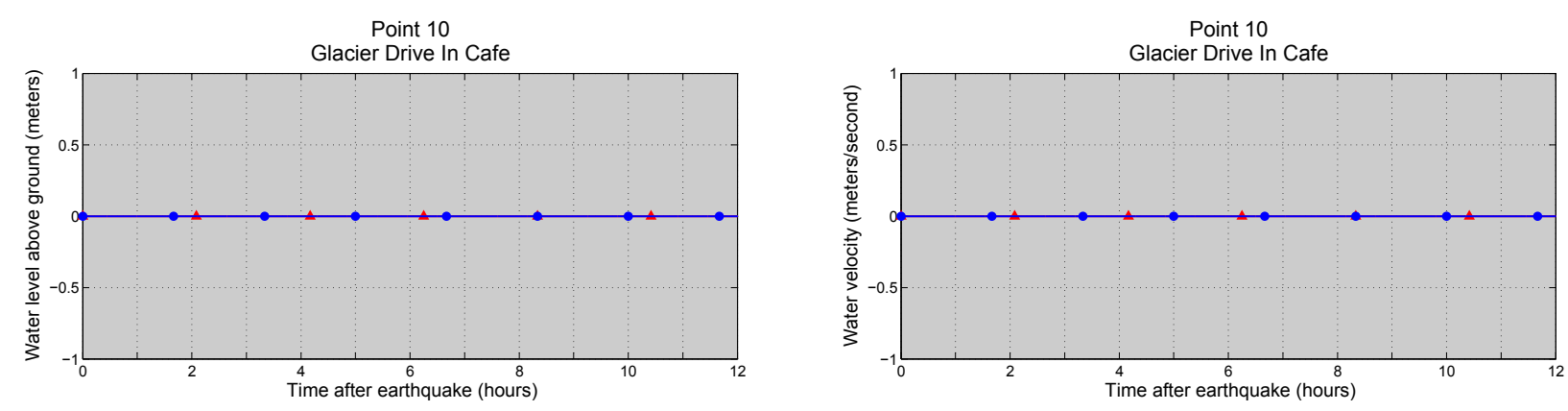

Elevation $1.2 \mathrm{~m}(4.1 \mathrm{ft})$

$\leadsto$ Scenario $8 \longrightarrow$ Scenario 9

Figure A5, continued. Time series of water level (left column) and velocity (right column) for tectonic scenarios 8-9 at selected locations shown in figures A1 and A2. Elevations of onshore locations and ocean depth at offshore locations are given based on the pre-earthquake MHHW datum. 

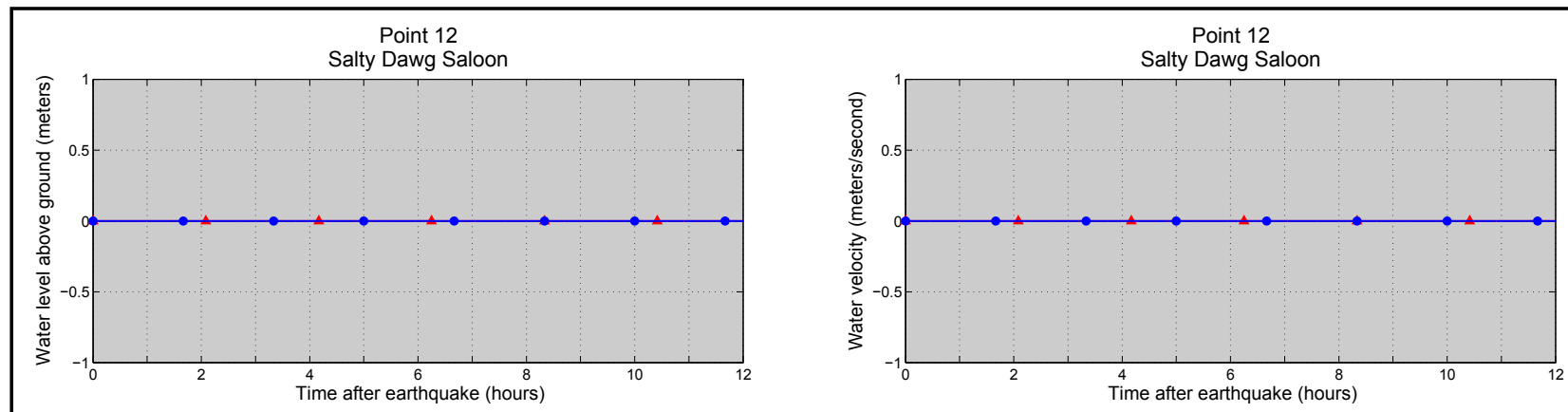

Elevation $3.6 \mathrm{~m}(11.7 \mathrm{ft})$

$\leftarrow$ Scenario $8 \rightarrow$ Scenario 9
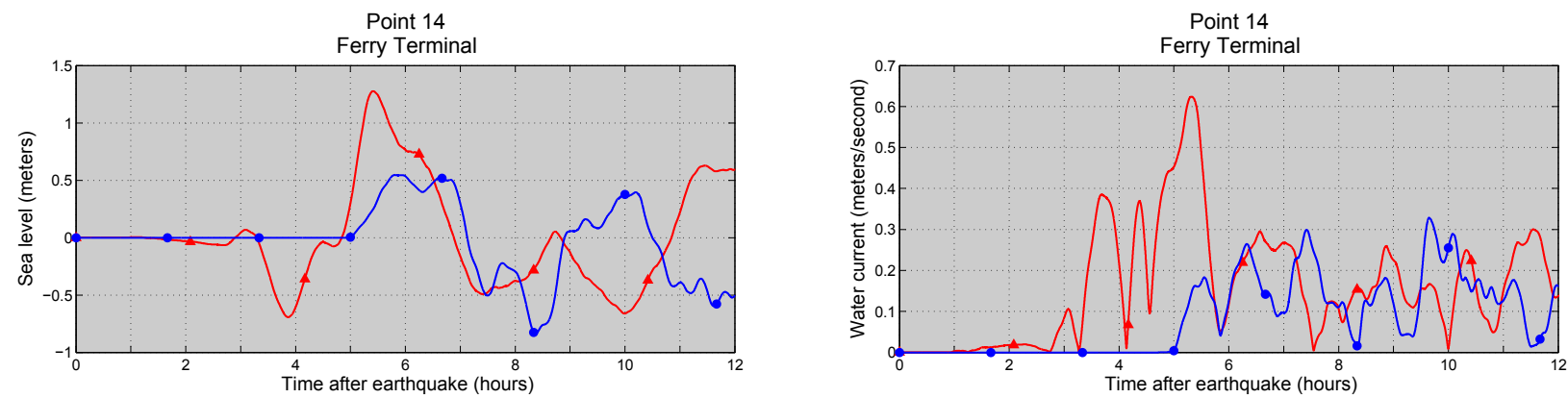

Depth $20.1 \mathrm{~m}(66.0 \mathrm{ft})$

- - Scenario 8 - Scenario 9
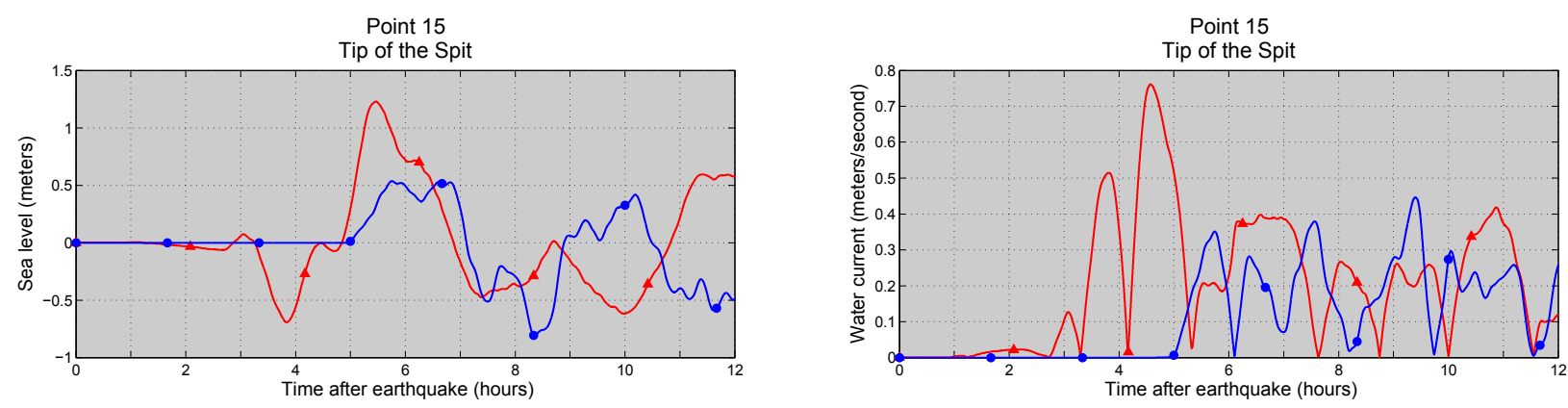

Depth $66.6 \mathrm{~m}(218.5 \mathrm{ft})$

$\neg$ Scenario $8 \longrightarrow$ Scenario 9
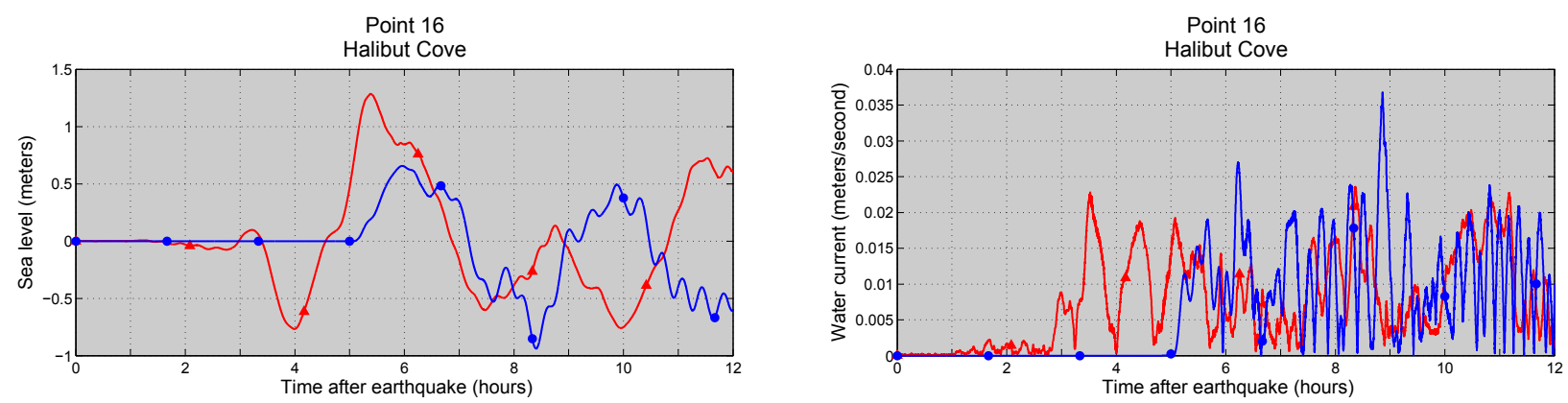

Depth $8.1 \mathrm{~m}(26.7 \mathrm{ft})$

$\triangle$ Scenario $8 \rightarrow$ Scenario 9

Figure A5, continued. Time series of water level (left column) and velocity (right column) for tectonic scenarios 8-9 at selected locations shown in figures A1 and A2. Elevations of onshore locations and ocean depth at offshore locations are given based on the pre-earthquake $\mathrm{MHHW}$ datum. 


\section{Report of Investigation 2018-5 v. 2}

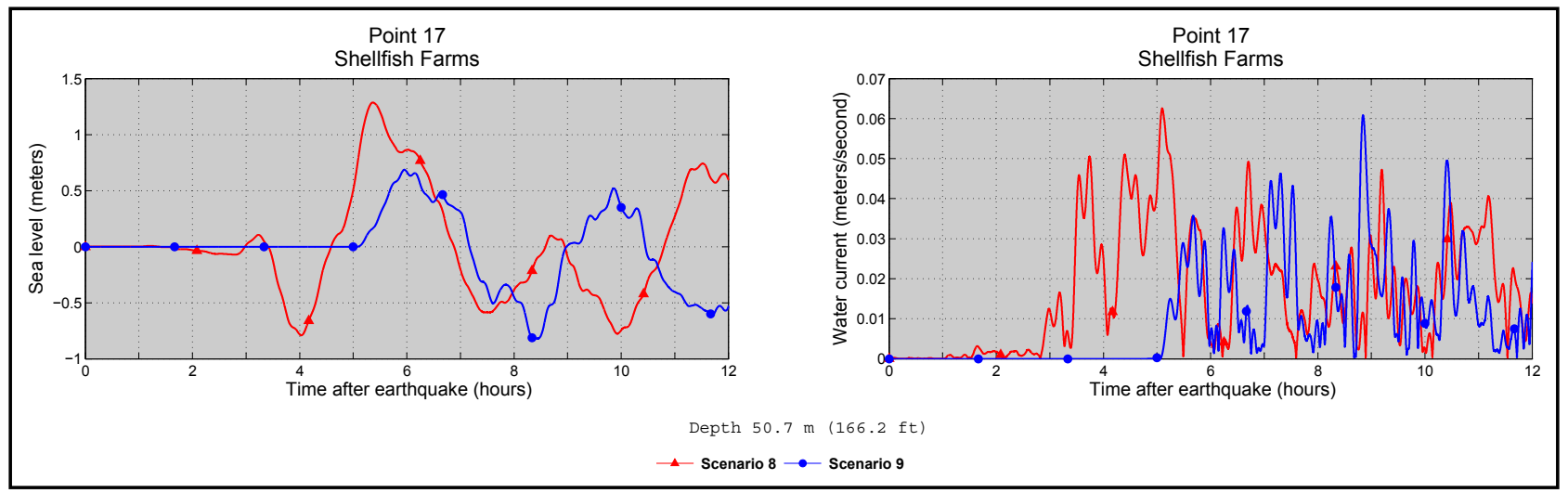

Figure A5, continued. Time series of water level (left column) and velocity (right column) for tectonic scenarios 8-9 at selected locations shown in figures A1 and A2. Elevations of onshore locations and ocean depth at offshore locations are given based on the pre-earthquake MHHW datum. 


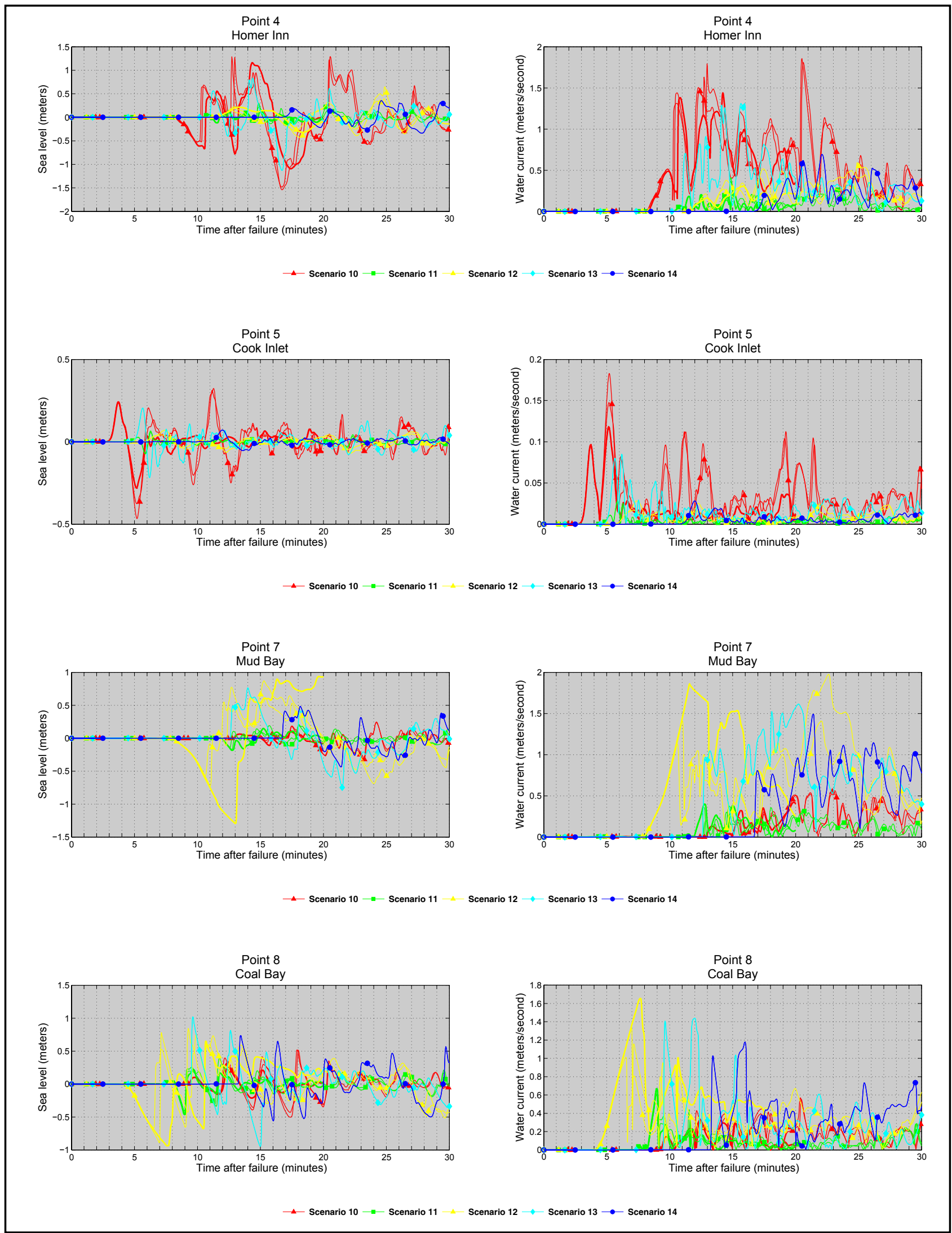

Figure A6. Time series of water level (left column) and velocity (right column) for landslide scenarios 10-14 at selected locations shown in figures $\mathrm{A} 1$ and $\mathrm{A} 2$. 

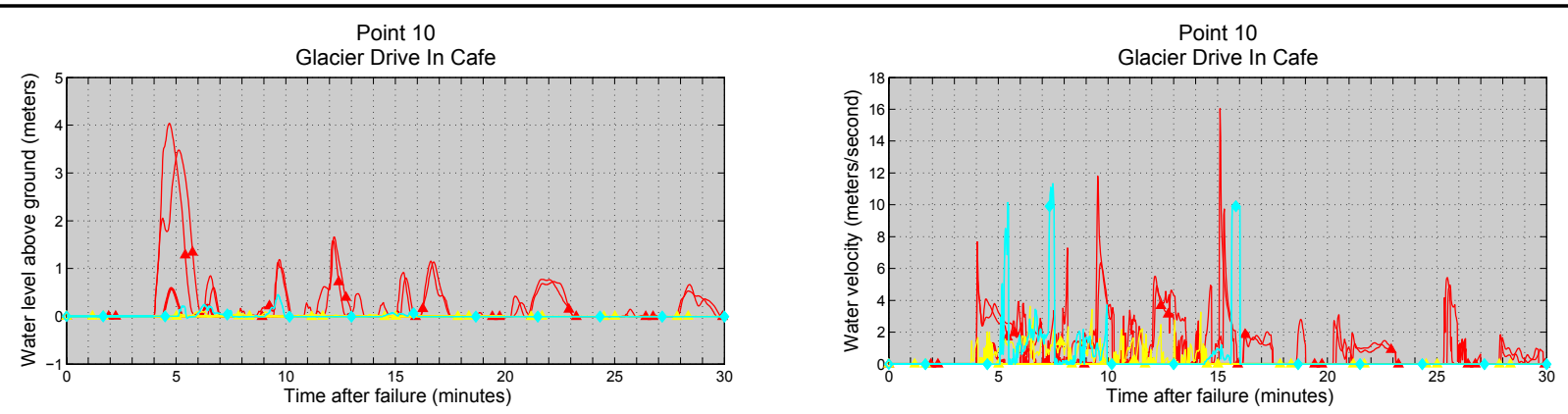

$\_$Scenario $10 \multimap$ Scenario $12 \multimap$ Scenario 13
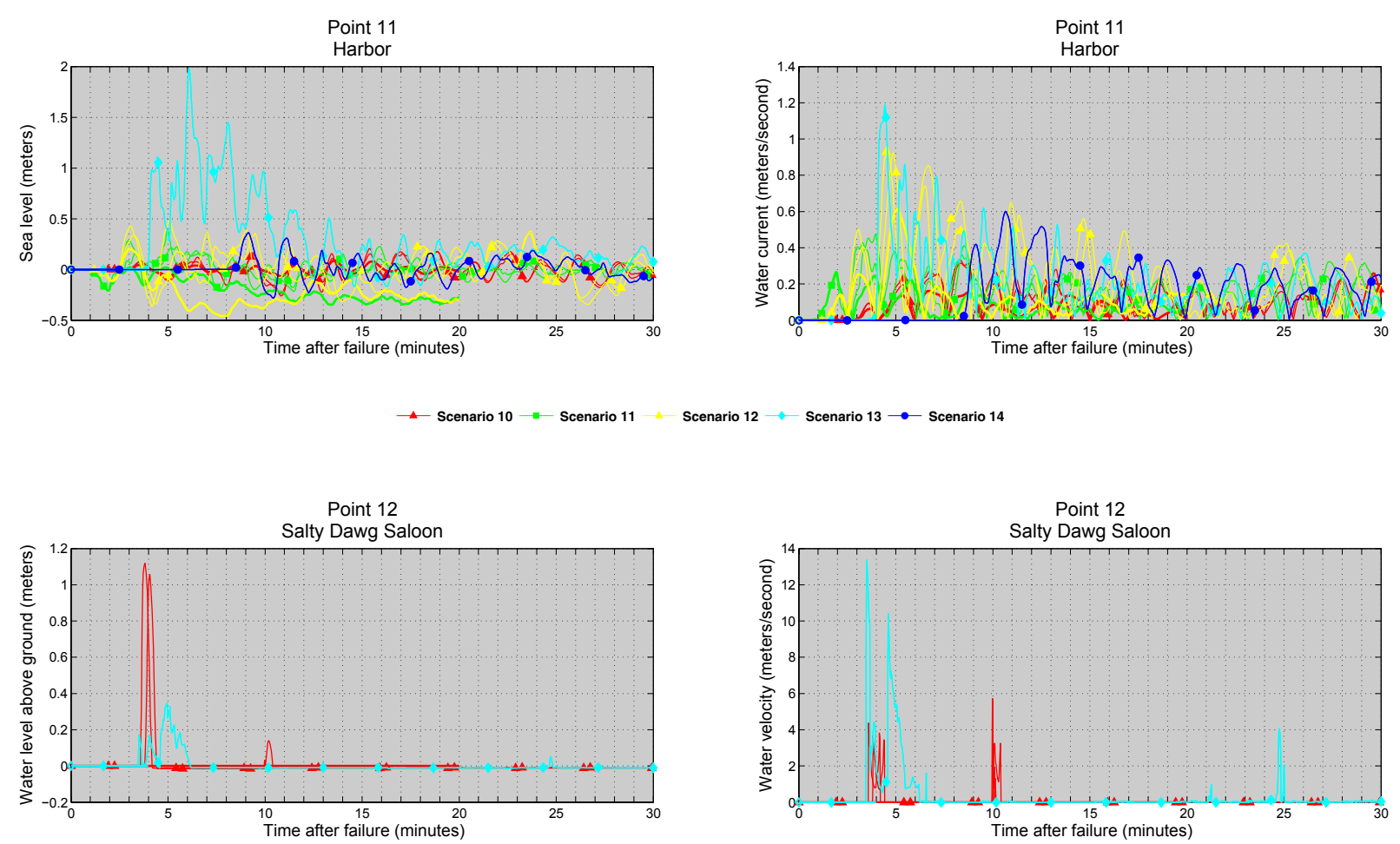

$\neg$ Scenario $10 \multimap-$ Scenario 13
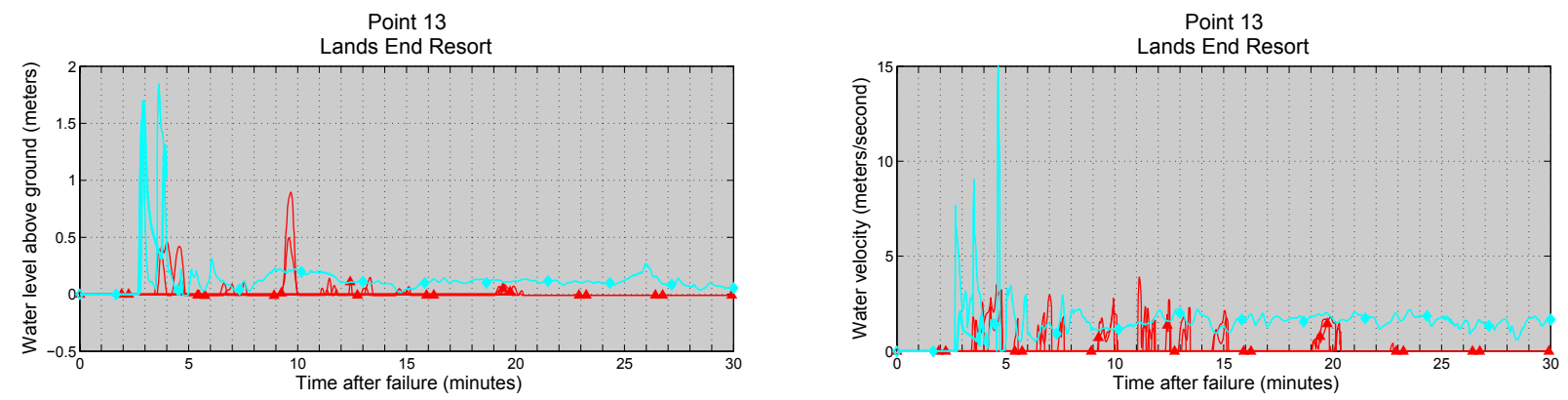

$\multimap$ Scenario $10 \multimap$ Scenario 13

Figure A6, continued. Time series of water level (left column) and velocity (right column) for landslide scenarios 10-14 at selected locations shown in figures $\mathrm{A} 1$ and $\mathrm{A} 2$. 


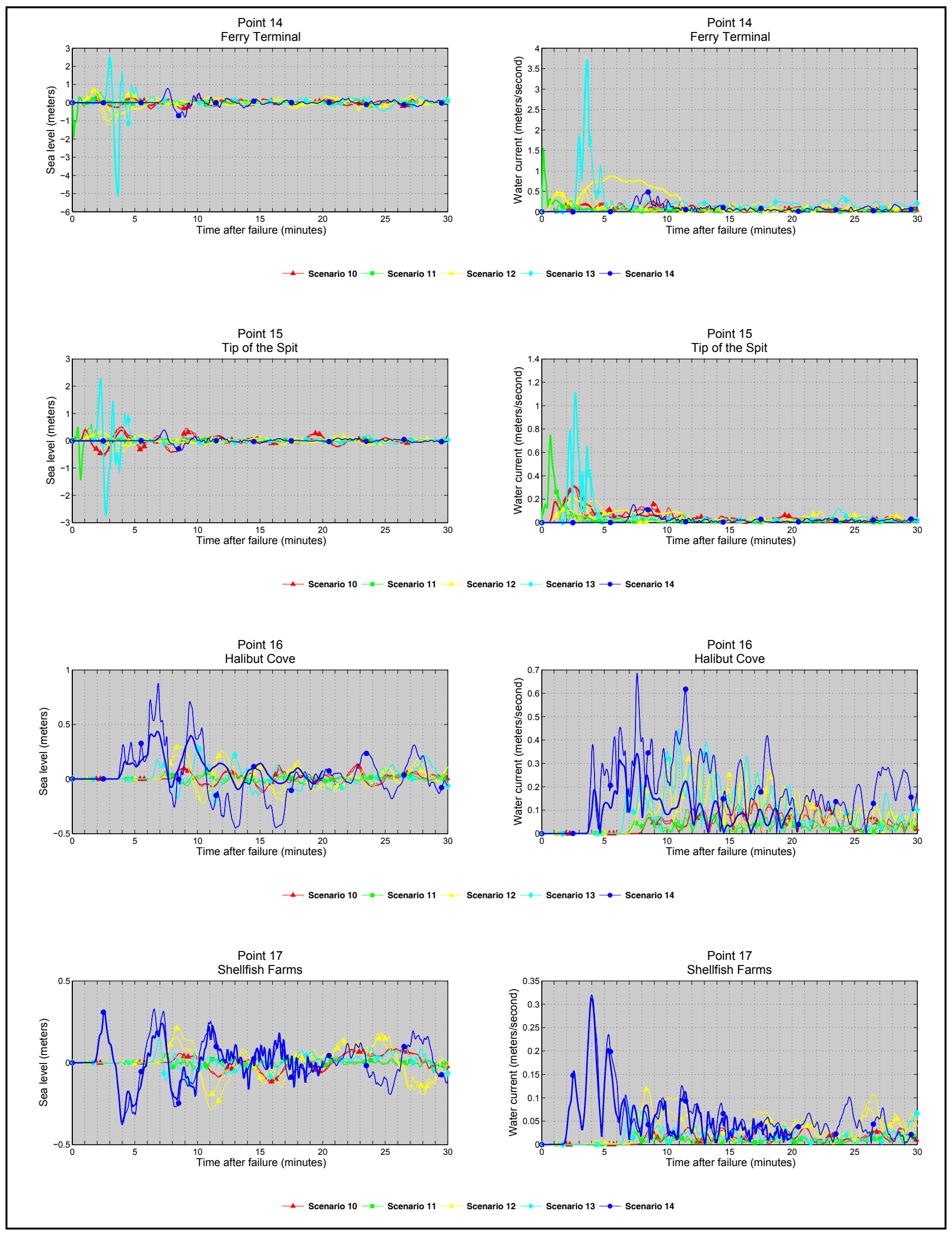

Figure A6, continued. Time series of water level (left column) and velocity (right column) for landslide scenarios 10-14 at selected locations shown in figures $\mathrm{A} 1$ and $\mathrm{A} 2$. 


\section{APPENDIX B}

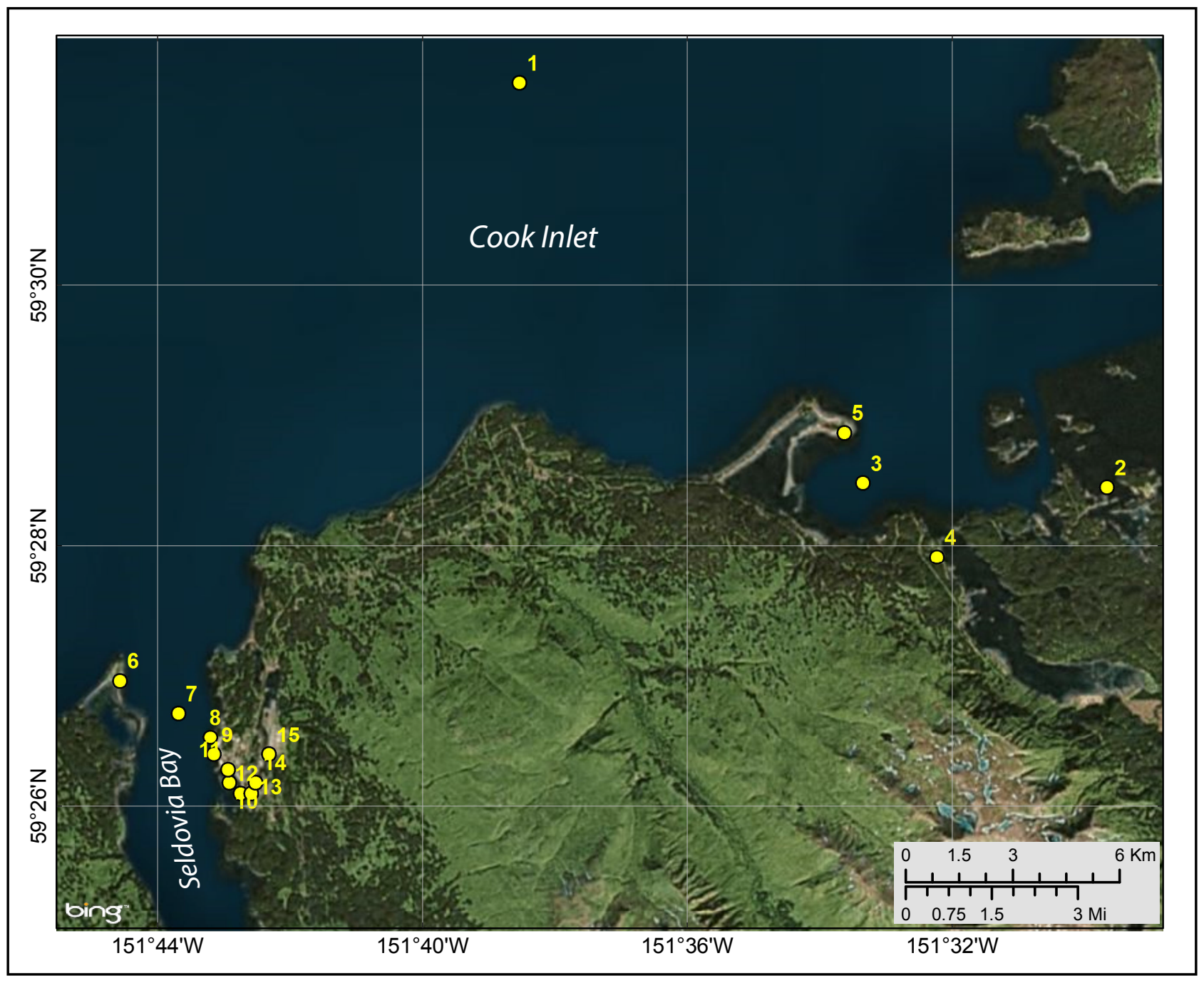

Figure B1. Locations of time series points in Cook Inlet and Seldovia Bay. The longitude and latitude locations of the time series points are listed in table B1. 


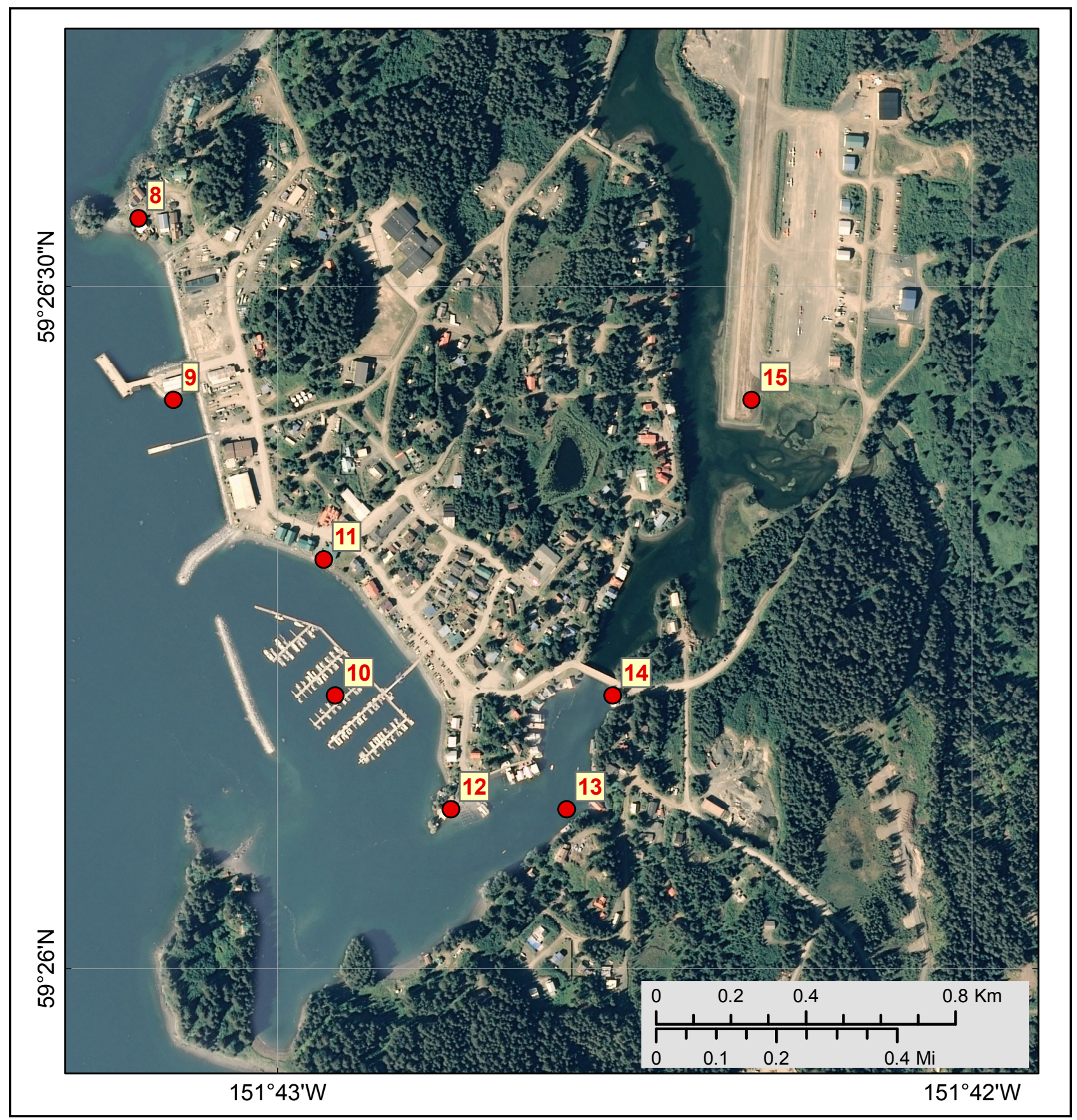

Figure B2. Detail map, locations of time series points near Seldovia. The latitude and longitude locations of the time series points are listed in table B1. 


\begin{tabular}{|c|c|c|c|c|c|c|c|c|c|c|c|c|c|c|c|c|c|}
\hline \multirow{9}{*}{\multicolumn{2}{|c|}{ 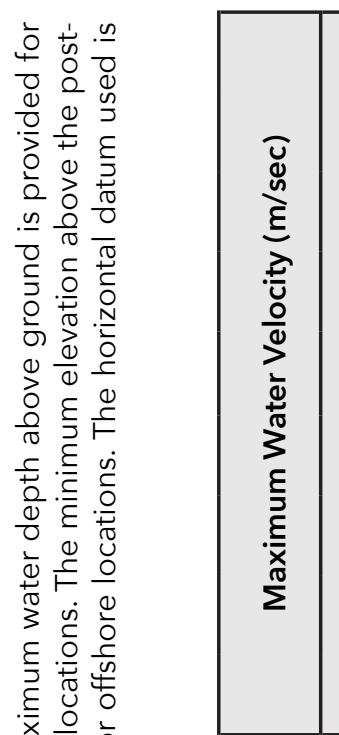 }} & $a$ & $\dddot{0}$ & $-\dot{0}$ & $\overline{0}$ & $\stackrel{\circ}{\circ}$ & $\stackrel{\circ}{\circ}$ & $\stackrel{\circ}{\circ}$ & $\begin{array}{l}a \\
\dot{0}\end{array}$ & 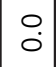 & $\check{0}$ & $\check{\circ}$ & $\dot{0}$ & $\dot{0}$ & $\check{0}$ & $\stackrel{\circ}{\circ}$ & $\stackrel{\circ}{\circ}$ \\
\hline & & $\infty$ & ก̃ & $\overline{0}$ & $\overline{0}$ & $\stackrel{\circ}{\circ}$ & 웅 & $\stackrel{\circ}{\circ}$ & $\begin{array}{ll}\infty \\
0 \\
0\end{array}$ & $\circ$ & $\begin{array}{c}n \\
0\end{array}$ & $\overline{0}$ & бo & ָ̃ & $\overline{0}$ & $\circ$ & $\stackrel{\circ}{\circ}$ \\
\hline & & $r$ & $\hat{o}$ & $\stackrel{0}{\circ}$ & $\stackrel{2}{0}$ & $\stackrel{\circ}{\circ}$ & $\stackrel{\circ}{\circ}$ & $\stackrel{m}{m}$ & $\begin{array}{l}\stackrel{0}{i} \\
\dot{i}\end{array}$ & $\stackrel{\circ}{i}$ & $\stackrel{\circ}{-}$ & $\begin{array}{l}0 \\
0\end{array}$ & $\stackrel{\circ}{\circ}$ & $\stackrel{\circ}{-}$ & $\stackrel{\infty}{\circ}$ & $\stackrel{+}{+}$ & $\stackrel{\circ}{-}$ \\
\hline & & $\begin{array}{lll}0 \\
0 \\
0\end{array}$ & 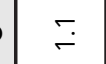 & $\stackrel{0}{0}$ & $\begin{array}{l}n \\
0\end{array}$ & $\hat{o}$ & $\stackrel{0}{\circ}$ & $\stackrel{N}{N}$ & $\stackrel{N}{N}$ & $\stackrel{m}{\sim}$ & $\begin{array}{l}0 \\
0\end{array}$ & $\stackrel{n}{0}$ & $\stackrel{\infty}{\circ}$ & 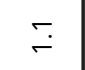 & $\stackrel{\infty}{0}$ & $\stackrel{+}{+}$ & $\stackrel{\sim}{-}$ \\
\hline & & مـ & $\stackrel{\circ}{\circ}$ & $\begin{array}{l}a \\
\dot{0}\end{array}$ & $\begin{array}{ll}m \\
0 \\
0\end{array}$ & $\hat{0}$ & $\hat{0}$ & $\grave{a}$ & $\hat{i}$ & $\stackrel{\infty}{-}$ & $\begin{array}{l}0 \\
0\end{array}$ & $\stackrel{?}{\circ}$ & $\stackrel{\infty}{\circ}$ & $\stackrel{\sim}{\sim}$ & $\stackrel{\infty}{\circ}$ & $\stackrel{+}{\circ}$ & $\stackrel{\stackrel{n}{+}}{\stackrel{2}{-}}$ \\
\hline & & $\begin{array}{c}5 \\
\bar{\nu} \\
\end{array}$ & $\stackrel{\infty}{0}$ & $\stackrel{m}{\longrightarrow}$ & $\begin{array}{ll}m \\
0 \\
0\end{array}$ & : & $\stackrel{0}{0}$ & $\stackrel{m}{\sim}$ & $\stackrel{0}{\sim}$ & $\stackrel{\stackrel{n}{\longrightarrow}}{\sim}$ & $\stackrel{t}{0}$ & $\stackrel{0}{0}$ & $\stackrel{\circ}{\circ}$ & $\stackrel{+}{\leftarrow}$ & $\hat{o}$ & $\overline{0}$ & O \\
\hline & & $m$ & $\stackrel{0}{0}$ & $\stackrel{0}{-}$ & \begin{tabular}{|l|}
$?$ \\
0
\end{tabular} & น? & $\stackrel{\infty}{0}$ & $\stackrel{n}{\sim}$ & $\stackrel{\circ}{m}$ & $\stackrel{\leftrightarrow}{\bullet}$ & $\begin{array}{l}0 \\
0\end{array}$ & $\begin{array}{l}\infty \\
0 \\
0\end{array}$ & $\stackrel{\circ}{-}$ & $\stackrel{m}{\stackrel{m}{2}}$ & à & $\stackrel{\infty}{\stackrel{\sim}{+}}$ & : \\
\hline & & $N$ & $\hat{o}$ & $\stackrel{\ominus}{\bullet}$ & 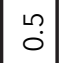 & $\stackrel{+}{0}$ & $\stackrel{\infty}{\circ}$ & $\stackrel{+}{\mathrm{N}}$ & $\stackrel{m}{m}$ & $\stackrel{\circ}{-}$ & $\begin{array}{l}0 \\
0\end{array}$ & $\begin{array}{l}\infty \\
0 \\
0\end{array}$ & å. & $\stackrel{N}{\sim}$ & $\stackrel{\circ}{-}$ & 임 & $\stackrel{\circ}{0}$ \\
\hline & & - & $\stackrel{n}{0}$ & $\stackrel{a}{0}$ & No & $\stackrel{m}{0}$ & $\stackrel{\llcorner}{\circ}$ & $\stackrel{\circ}{\circ}$ & $\stackrel{+\infty}{\leftarrow}$ & $\stackrel{0}{0}$ & $\tilde{O}$ & $\dddot{0}$ & $\stackrel{m}{0}$ & $\stackrel{n}{0}$ & $\stackrel{ナ}{0}$ & $\dot{m}$ & $\stackrel{\circ}{\circ}$ \\
\hline & & $a$ & $\hat{o}$ & $\begin{array}{l}\infty \\
0 \\
0\end{array}$ & $\hat{0}$ & 웅 & 웅 & 웅 & $\hat{0}$ & 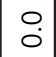 & $\hat{0}$ & $\hat{0}$ & $\hat{0}$ & $\stackrel{m}{0}$ & $\hat{0}$ & $\stackrel{0}{\circ}$ & $\stackrel{\circ}{\circ}$ \\
\hline & & $\infty$ & 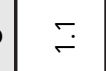 & $\stackrel{m}{-}$ & $\stackrel{\sim}{-}$ & ¿́ & $\check{0}$ & $\stackrel{\circ}{\circ}$ & $\check{-}$ & $\stackrel{\circ}{\circ}$ & $\check{-}$ & 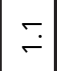 & 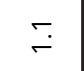 & $\hat{0}$ & 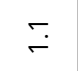 & $\stackrel{\circ}{\circ}$ & $\stackrel{\circ}{\circ}$ \\
\hline & & 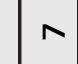 & $\stackrel{\circ}{\sim}$ & $\hat{\infty}$ & \begin{tabular}{|l|} 
\\
$\infty$ \\
$\infty$
\end{tabular} & $\stackrel{\circ}{\stackrel{2}{r}}$ & $\stackrel{N}{N}$ & $\stackrel{+}{\text { in }}$ & $\begin{array}{c}N \\
\infty \\
\infty\end{array}$ & $\check{r}$ & $\begin{array}{l}0 \\
\infty\end{array}$ & \begin{tabular}{|l|}
$\stackrel{0}{0}$ \\
$\infty$
\end{tabular} & 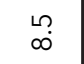 & $\stackrel{N}{\infty}$ & $\stackrel{\circ}{\infty}$ & $\begin{array}{l}\infty \\
\vdots \\
0\end{array}$ & $\stackrel{\stackrel{n}{+}}{+}$ \\
\hline$\frac{0}{0}$ & 20 & 0 & $\stackrel{\circ}{\circ}$ & $\stackrel{0}{\check{E}}$ & \begin{tabular}{|l|} 
\\
\\
\end{tabular} & $\stackrel{\circ}{\circ}$ & $\stackrel{\nabla}{\sigma}$ & : & 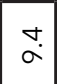 & $\begin{array}{l}m \\
\infty\end{array}$ & $\stackrel{n}{a}$ & $\stackrel{0}{a}$ & $\stackrel{\circ}{\circ}$ & $\stackrel{N}{a}$ & $\hat{a}$ & $\begin{array}{l}0 \\
\infty\end{array}$ & மீ \\
\hline & 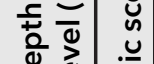 & 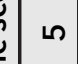 & : & $\stackrel{\stackrel{n}{\sim}}{\sim}$ & $\check{\pi}$ & $\overline{6}$ & $\stackrel{\infty}{\infty}$ & $\stackrel{N}{n}$ & $\hat{n}$ & $\stackrel{+}{+}$ & $\hat{n}$ & $\begin{array}{l}\infty \\
\stackrel{\infty}{\omega}\end{array}$ & $\stackrel{\infty}{\infty}$ & $\stackrel{\llcorner}{\llcorner}$ & i. & $\stackrel{\circ}{+}$ & $\stackrel{+}{\leftarrow}$ \\
\hline & 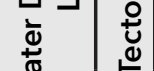 & 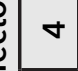 & $\stackrel{\sim}{\sim}$ & $\begin{array}{l}a \\
i\end{array}$ & $\begin{array}{c}m \\
\stackrel{m}{n}\end{array}$ & $\stackrel{\circ}{+}$ & $\stackrel{\circ}{+}$ & 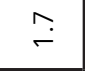 & \begin{tabular}{|l|}
$\stackrel{n}{+}$ \\
\end{tabular} & $\bar{m}$ & $\check{+}$ & $\stackrel{m}{+}$ & $\stackrel{m}{+}$ & $\stackrel{\circ}{+}$ & $\stackrel{\circ}{+}$ & $\hat{i}$ & $\stackrel{\circ}{\circ}$ \\
\hline & & $m$ & $\hat{m}$ & $\stackrel{\triangleright}{\dot{*}}$ & $\stackrel{\llcorner}{\sim}$ & $\dot{m}$ & $\stackrel{m}{m}$ & $\hat{o}$ & $\bar{m}$ & $\stackrel{\rho}{r}$ & $\bar{m}$ & $\stackrel{N}{n}$ & $\stackrel{N}{m}$ & $\stackrel{a}{i}$ & $\stackrel{\oplus}{\infty}$ & $\stackrel{\ominus}{\leftarrow}$ & $\stackrel{\circ}{\circ}$ \\
\hline & $\overline{\bar{\varepsilon}}$ & $N$ & $\stackrel{\circ}{m}$ & $\hat{m}$ & $\stackrel{\sim}{m}$ & $\stackrel{\sim}{N}$ & $\stackrel{m}{\sim}$ & $\stackrel{m}{0}$ & $\hat{i}$ & 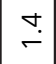 & $\stackrel{\circ}{\sim}$ & $\stackrel{\infty}{i}$ & $\hat{i}$ & $\stackrel{+}{i}$ & $\stackrel{a}{i}$ & $\stackrel{o}{o}$ & : \\
\hline & & - & $\stackrel{\triangleright}{i}$ & $\stackrel{N}{m}$ & $\stackrel{a}{\mathrm{i}}$ & $\stackrel{.}{-}$ & $\stackrel{f}{=}$ & $\stackrel{\circ}{\circ}$ & $\stackrel{m}{\sim}$ & $\check{r}$ & $\stackrel{\sim}{\sim}$ & $\stackrel{\sim}{\sim}$ & $\stackrel{+}{\sim}$ & $\stackrel{\circ}{\mathrm{i}}$ & $\stackrel{\downarrow}{\sim}$ & $\begin{array}{l}\circ \\
\circ\end{array}$ & $\stackrel{\circ}{\circ}$ \\
\hline 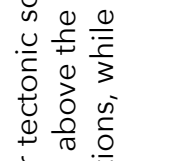 & 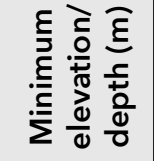 & & 然 & $\begin{array}{l}\stackrel{\llcorner}{0} \\
\stackrel{0}{\circ}\end{array}$ & $\bar{a}$ & 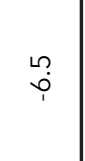 & ְִ & $\stackrel{\sim}{+}$ & $\begin{array}{l}0 \\
\sigma^{\circ}\end{array}$ & $\begin{array}{l}\text { L̊ } \\
\text { Lீ }\end{array}$ & $\stackrel{⿱}{\stackrel{2}{*}}$ & $\begin{array}{l}\infty \\
\sigma^{\prime}\end{array}$ & $\hat{o}$ & $\stackrel{+}{\circ}$ & $\overline{\dot{\omega}}$ & นึ. & $\stackrel{\infty}{\sim}$ \\
\hline $\begin{array}{l}\overline{\bar{D}} \overline{0} \\
\overline{0} \\
\overline{0} \\
3 \frac{0}{0}\end{array}$ & 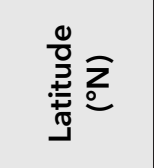 & & 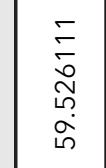 & 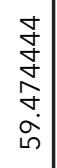 & 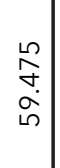 & 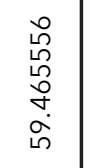 & 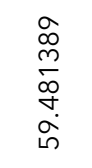 & 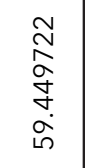 & 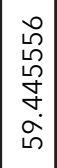 & \begin{tabular}{l}
$\stackrel{\sim}{\sim}$ \\
\multirow{J}{*}{} \\
$\stackrel{\sigma}{n}$
\end{tabular} & 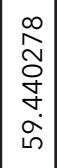 & 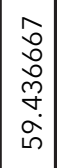 & 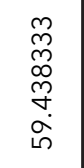 & 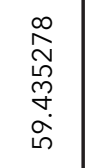 & 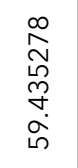 & 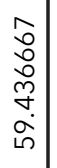 & 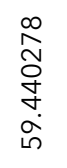 \\
\hline 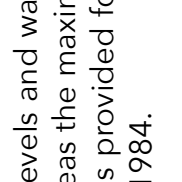 & 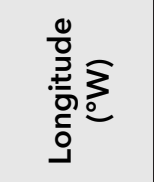 & & 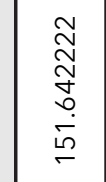 & 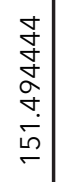 & 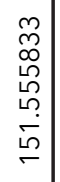 & 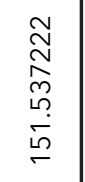 & 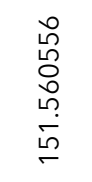 & 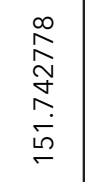 & 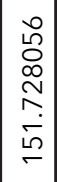 & $\begin{array}{l}\stackrel{N}{\Sigma} \\
\stackrel{5}{r}\end{array}$ & 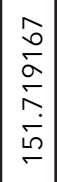 & 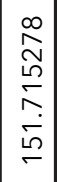 & 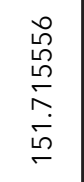 & $\begin{array}{l}\stackrel{\mathscr{n}}{N} \\
\stackrel{N}{\Sigma} \\
\stackrel{\Sigma}{\sim}\end{array}$ & $\begin{array}{l}\underset{N}{N} \\
\stackrel{2}{0} \\
\stackrel{2}{5} \\
\stackrel{5}{\leftarrow}\end{array}$ & 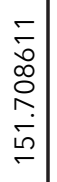 & 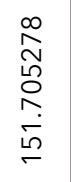 \\
\hline$\stackrel{\Perp}{\rightleftharpoons}$ & $\frac{0}{n}$ & & 0 & 0 & 0 & $\sim$ & $\sim s$ & $\sim$ & 0 & 0 & 0 & 0 & 0 & 0 & 0 & $\backsim$ & $n$ \\
\hline 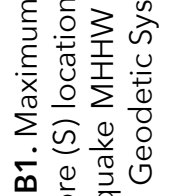 & $\begin{array}{l}\overline{0} \\
\frac{0}{J} \\
\end{array}$ & & 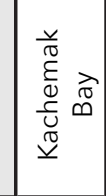 & 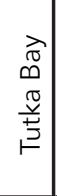 & 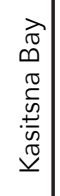 & 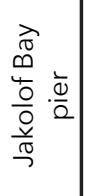 & 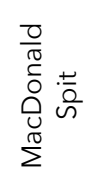 & 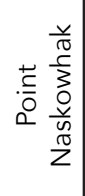 & 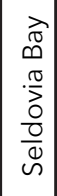 & 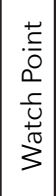 & 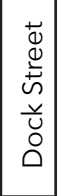 & $\begin{array}{l}\frac{1}{0} \\
\frac{0}{2} \\
\frac{0}{T} \\
T \\
\frac{1}{\pi} \\
0 \\
0\end{array}$ & 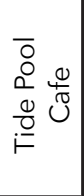 & 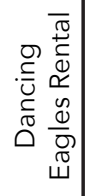 & $\begin{array}{l}\frac{\pi}{2} \frac{}{0} \\
\frac{0}{0} \frac{1}{0} \\
\frac{0}{\infty} \frac{0}{\omega}\end{array}$ & 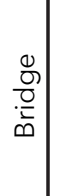 & 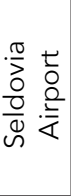 \\
\hline & $\#$ & & - & $\sim$ & $m$ & $\nabla$ & Lก & 0 & $\wedge$ & $\infty$ & $\alpha$ & $\stackrel{\circ}{-}$ & $=$ & $\cong$ & $\stackrel{m}{\square}$ & $\nabla$ & $\stackrel{\llcorner}{\leftarrow}$ \\
\hline
\end{tabular}




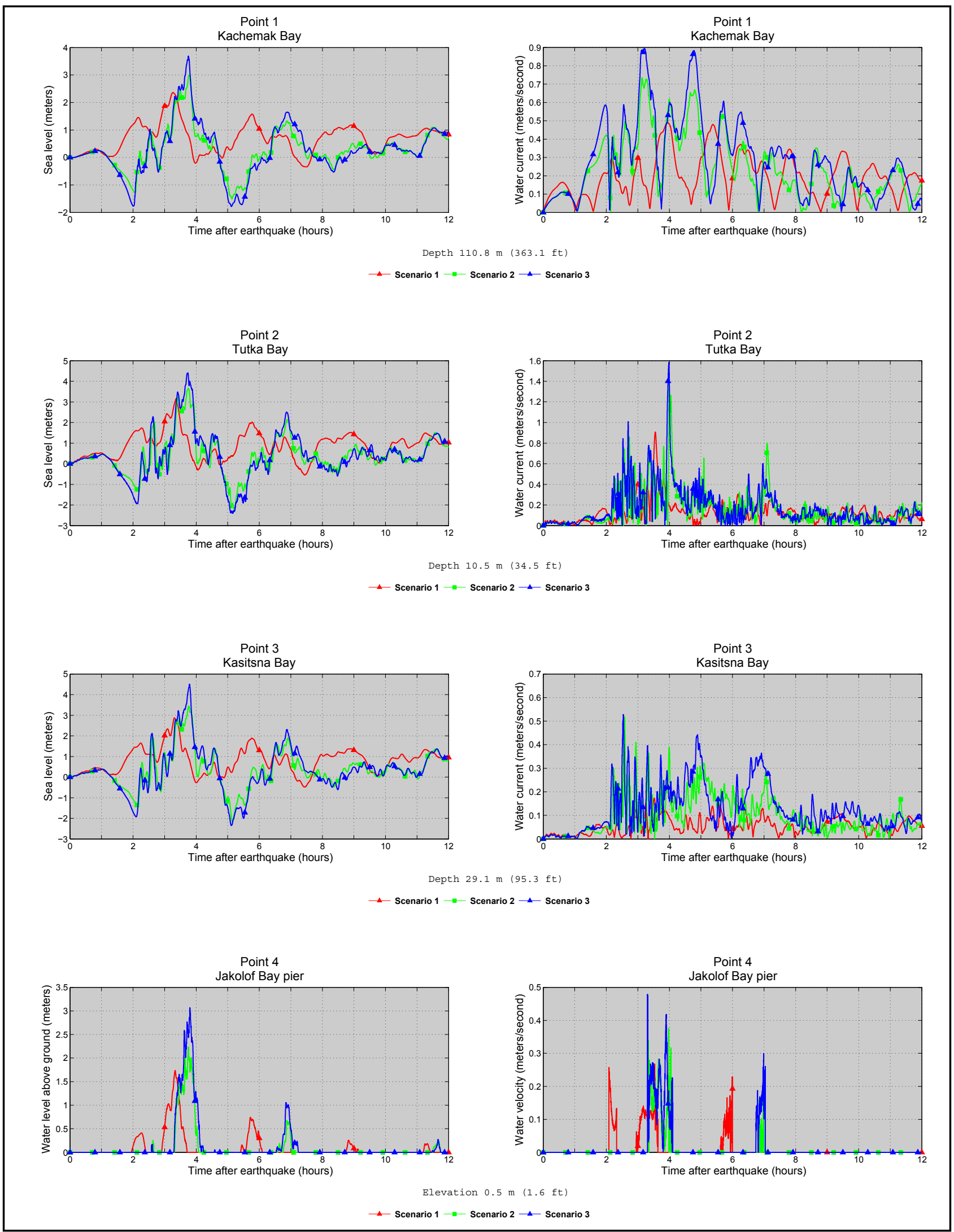

Figure B3. Time series of water level (left column) and velocity (right column) for tectonic scenarios 1-3 at selected locations shown in figure B1. Elevations of onshore locations and ocean depth at offshore locations are given based on the pre-earthquake MHHW datum. 

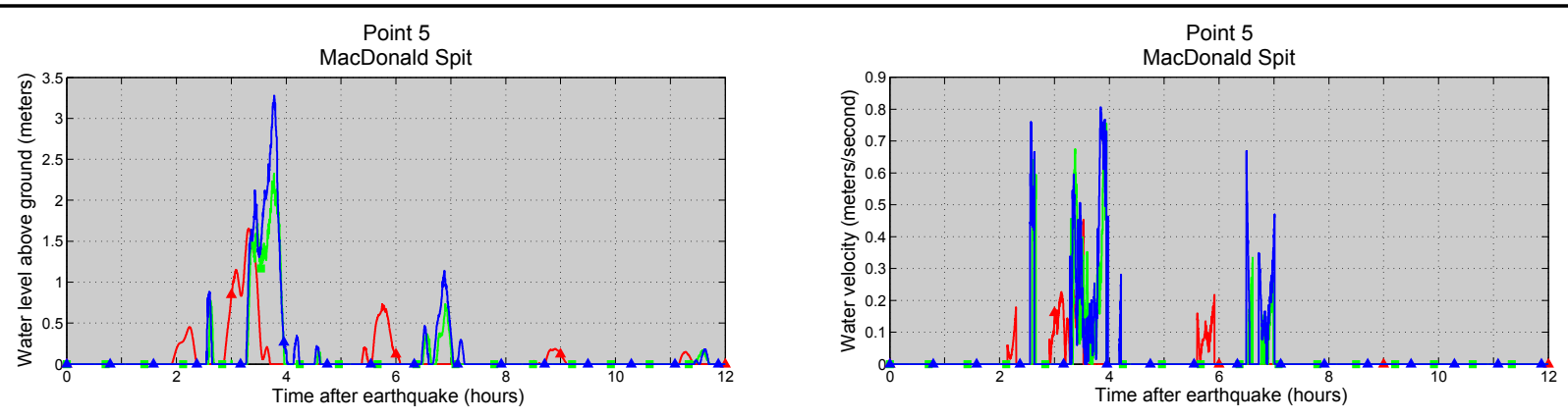

Elevation $0.5 \mathrm{~m}(1.6 \mathrm{ft})$

$\triangle$ Scenario $1-$ Scenario $2 \multimap$ Scenario 3
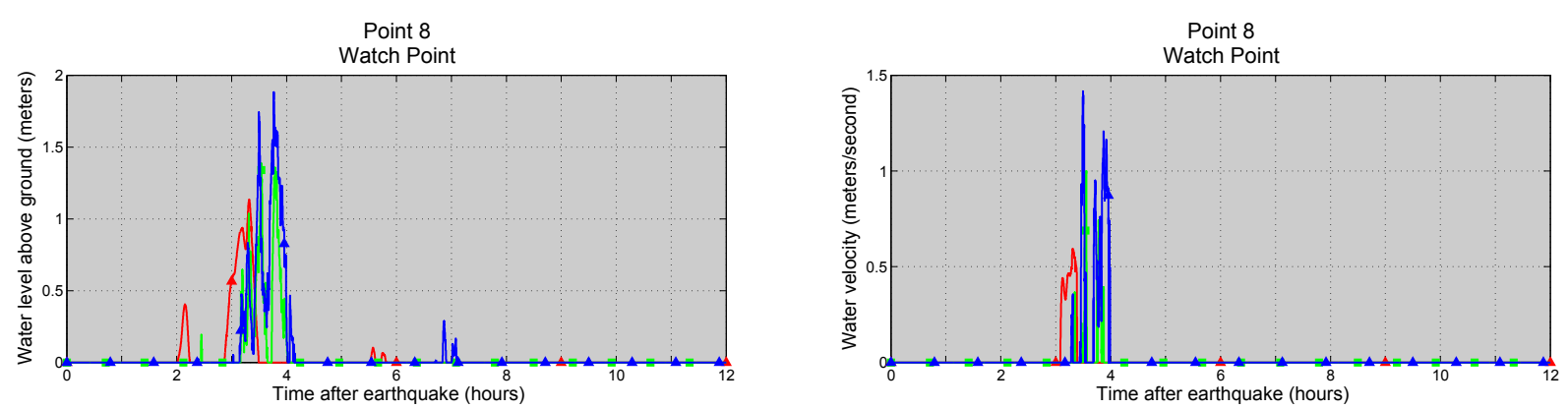

Elevation $0.7 \mathrm{~m}(2.2 \mathrm{ft})$

$\triangle$ Scenario $1 \rightarrow$ Scenario $2 \multimap$ Scenario 3
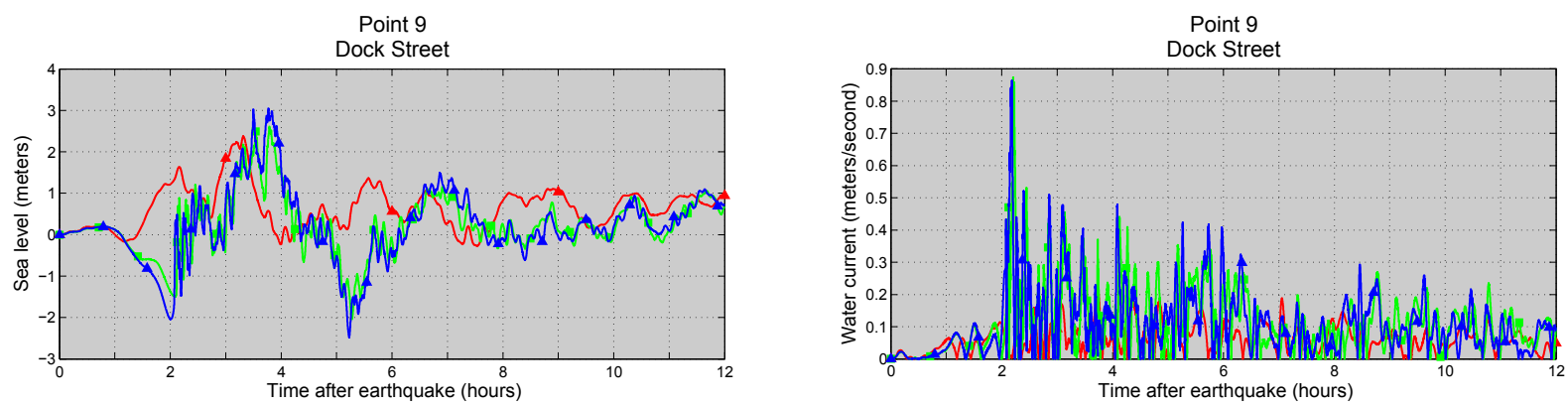

Depth $7.4 \mathrm{~m}(24.3 \mathrm{ft})$

$\leadsto$ Scenario $1 \longrightarrow$ Scenario $2 \rightarrow$ Scenario 3
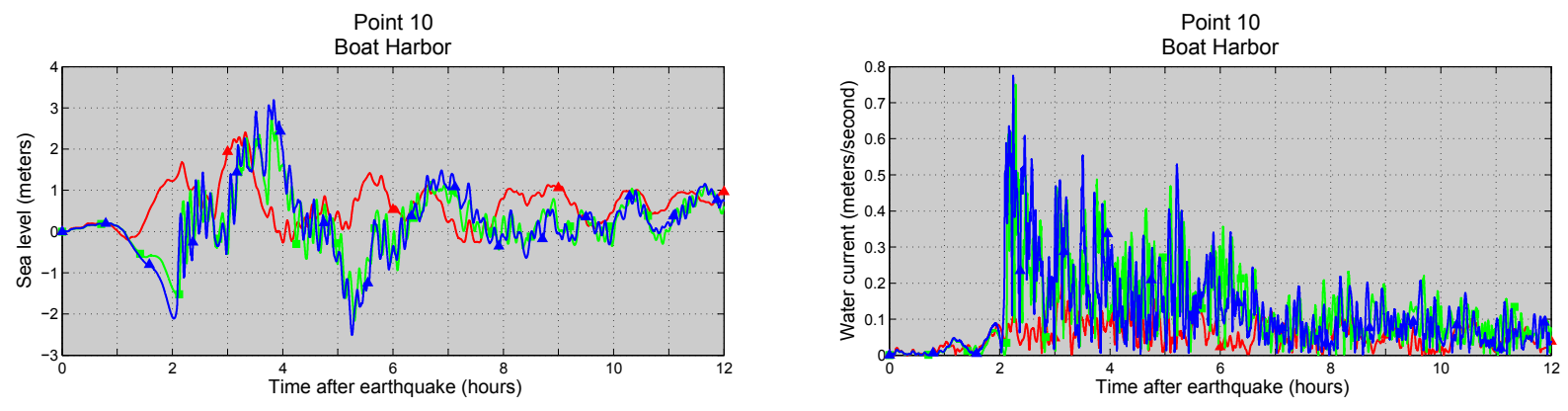

Depth $9.8 \mathrm{~m}(32.3 \mathrm{ft})$

$\triangle$ Scenario $1 \rightarrow$ Scenario $2 \simeq$ Scenario 3

Figure B3, continued. Time series of water level (left column) and velocity (right column) for tectonic scenarios 1-3 at selected locations shown in figure B1. Elevations of onshore locations and ocean depth at offshore locations are given based on the pre-earthquake MHHW datum. 


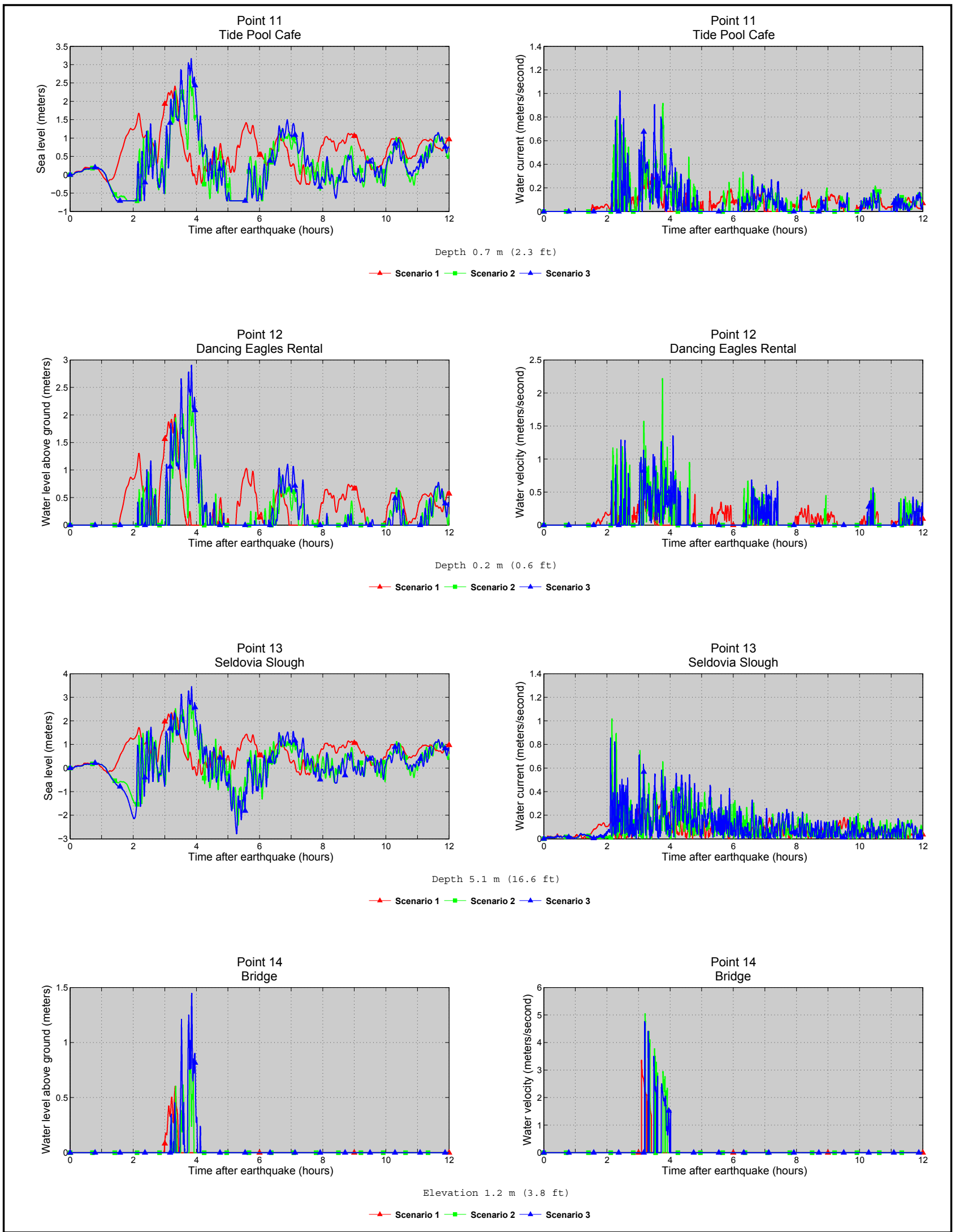

Figure B3, continued. Time series of water level (left column) and velocity (right column) for tectonic scenarios 1-3 at selected locations shown in figure B1. Elevations of onshore locations and ocean depth at offshore locations are given based on the pre-earthquake MHHW datum. 
Report of Investigation $2018-5$ v. 2

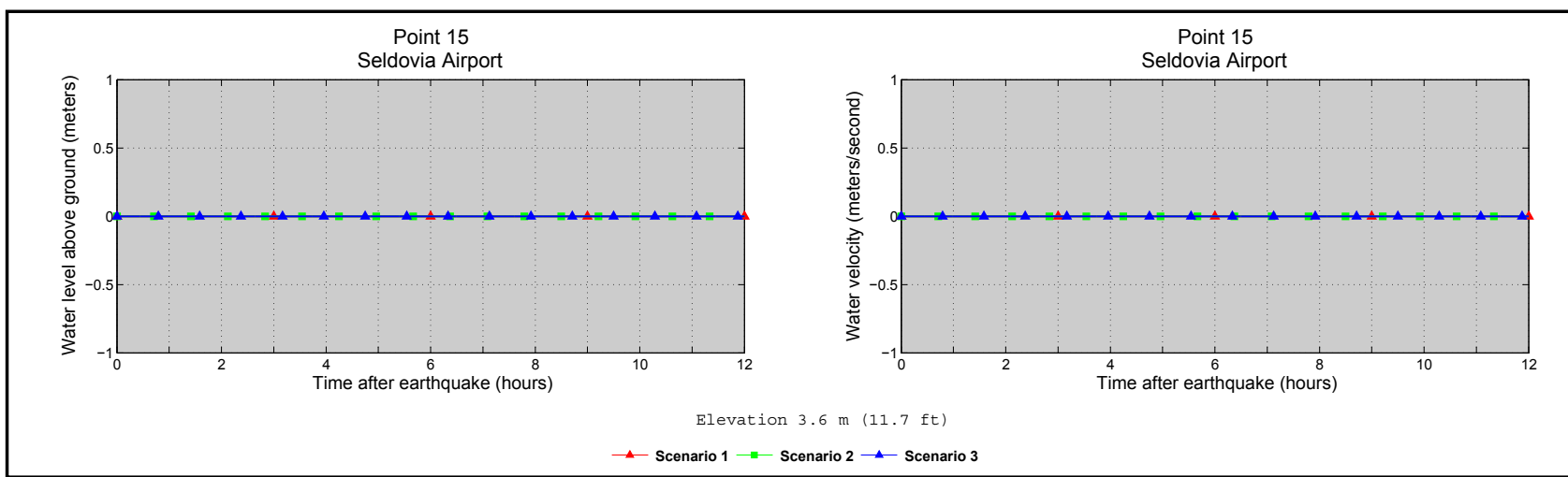

Figure B3, continued. Time series of water level (left column) and velocity (right column) for tectonic scenarios 1-3 at selected locations shown in figure B1. Elevations of onshore locations and ocean depth at offshore locations are given based on the pre-earthquake MHHW datum. 


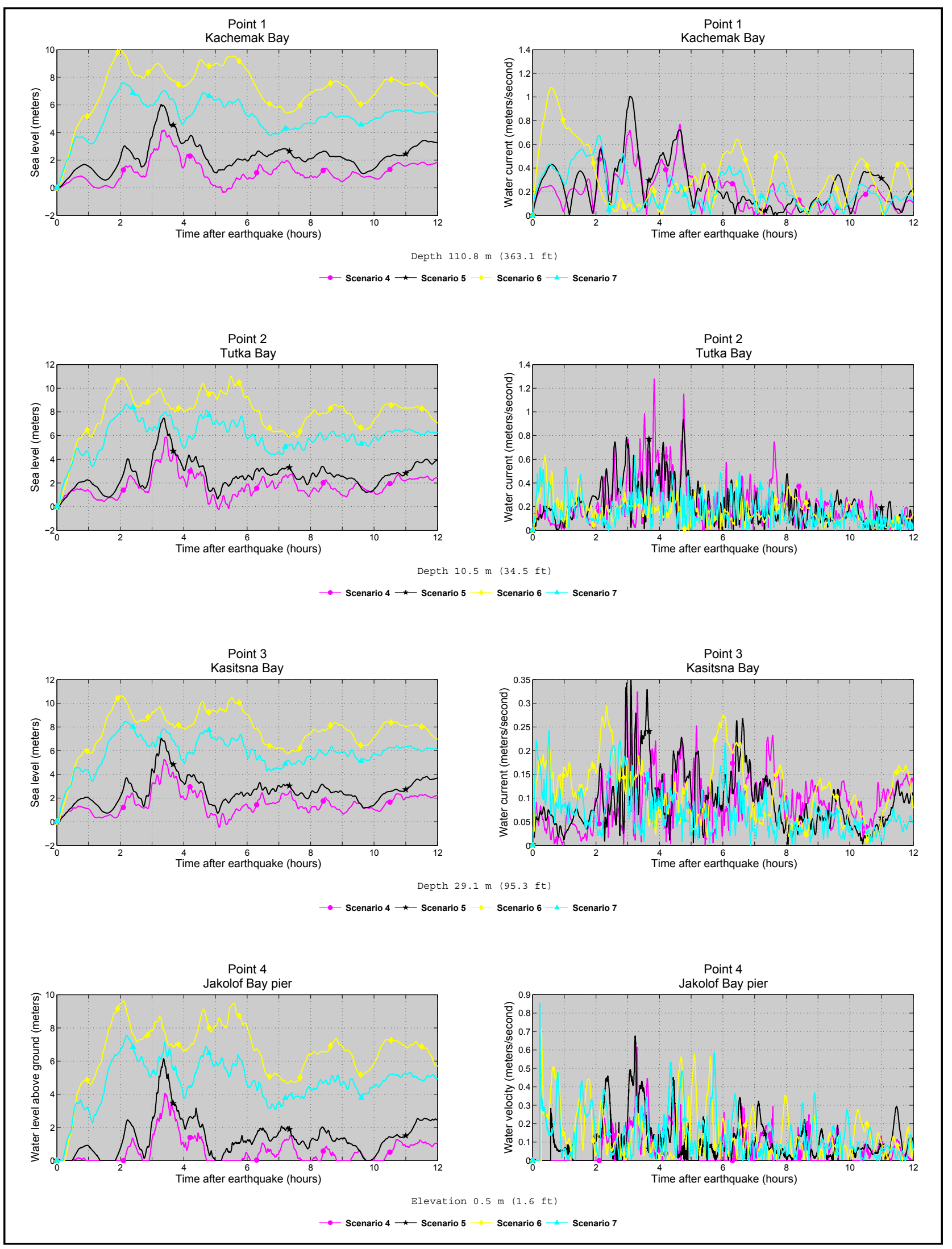

Figure B4. Time series of water level (left column) and velocity (right column) for tectonic scenarios 4-7 at selected locations shown in figure B1. Elevations of onshore locations and ocean depth at offshore locations are given based on the pre-earthquake MHHW datum. 

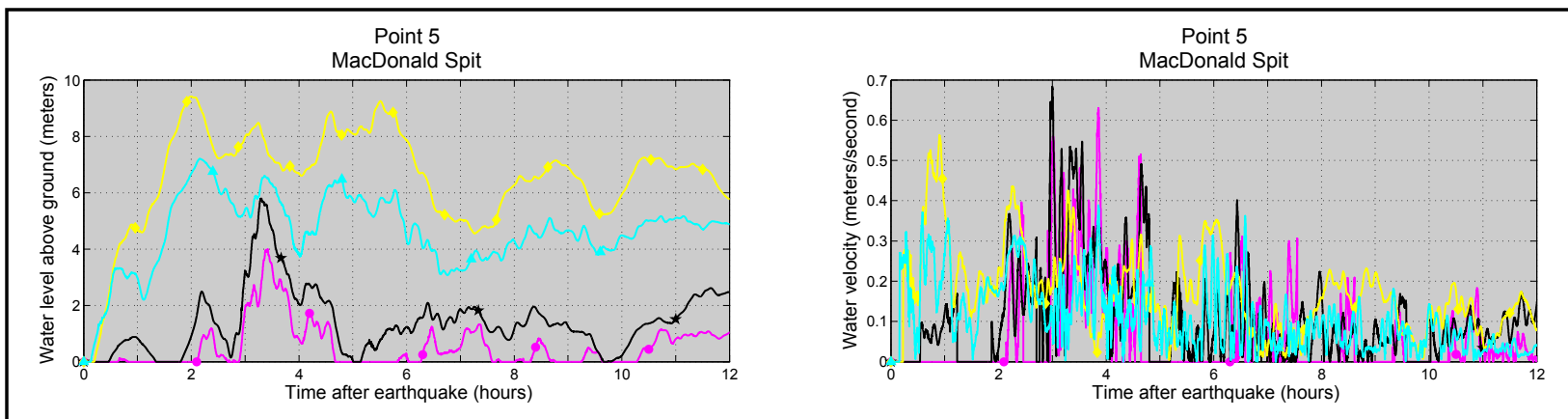

Elevation $0.5 \mathrm{~m}$ (1.6 ft)

$\multimap$ Scenario $4 \rightarrow$ Scenario $5 \multimap$ Scenario $6 \leadsto$ Scenario 7
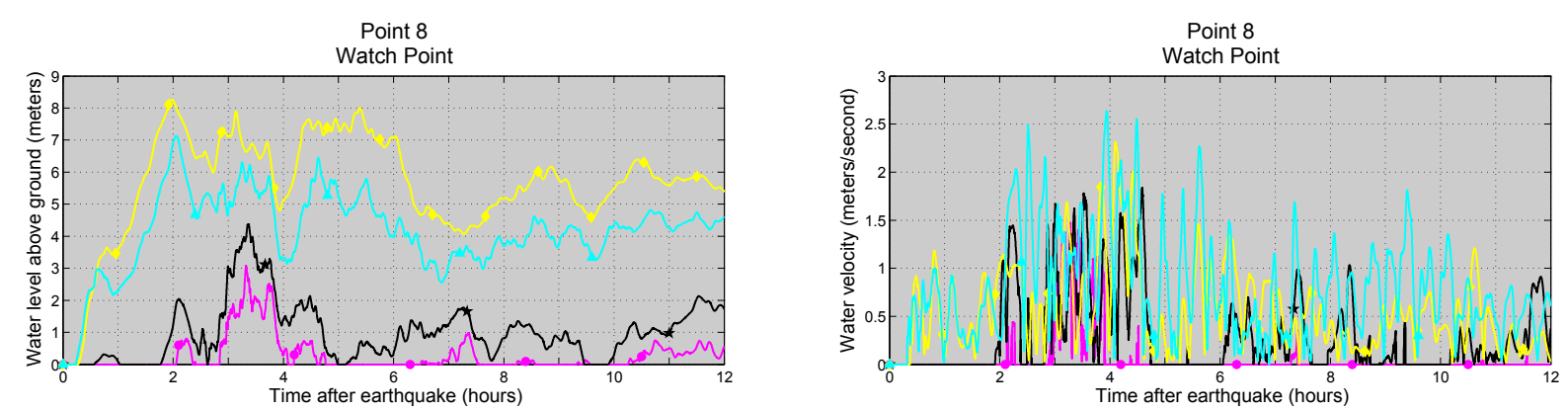

Elevation $0.7 \mathrm{~m}(2.2 \mathrm{ft})$

$\multimap$ Scenario $4 \longrightarrow$ Scenario $5 \multimap$ Scenario $6 \multimap$ Scenario 7
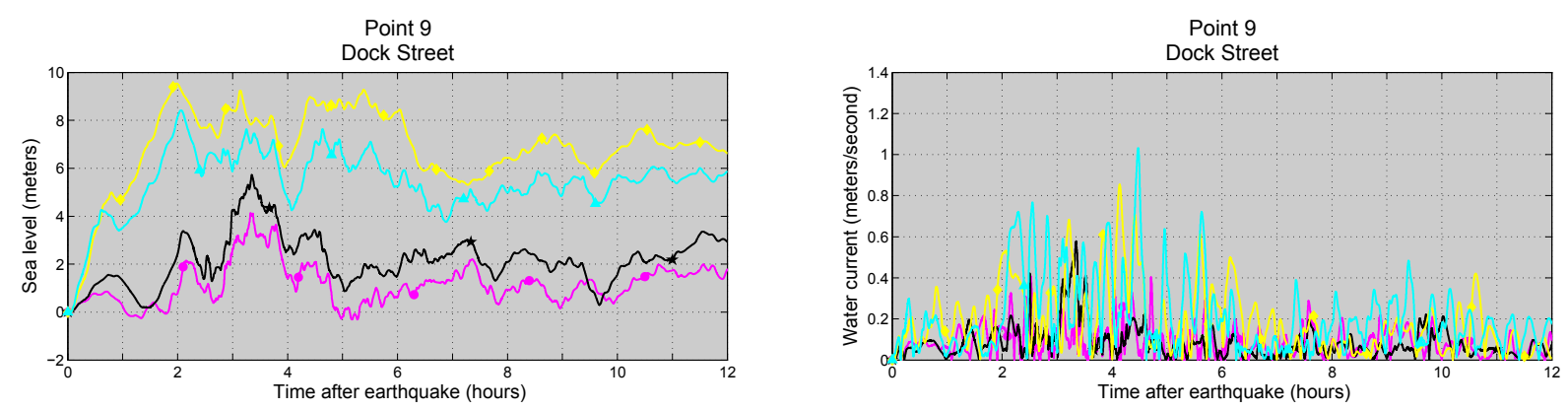

Depth $7.4 \mathrm{~m}(24.3 \mathrm{ft})$

$\rightarrow$ Scenario $4 \rightarrow$ Scenario $5 \multimap$ Scenario $6 \nrightarrow$ Scenario 7
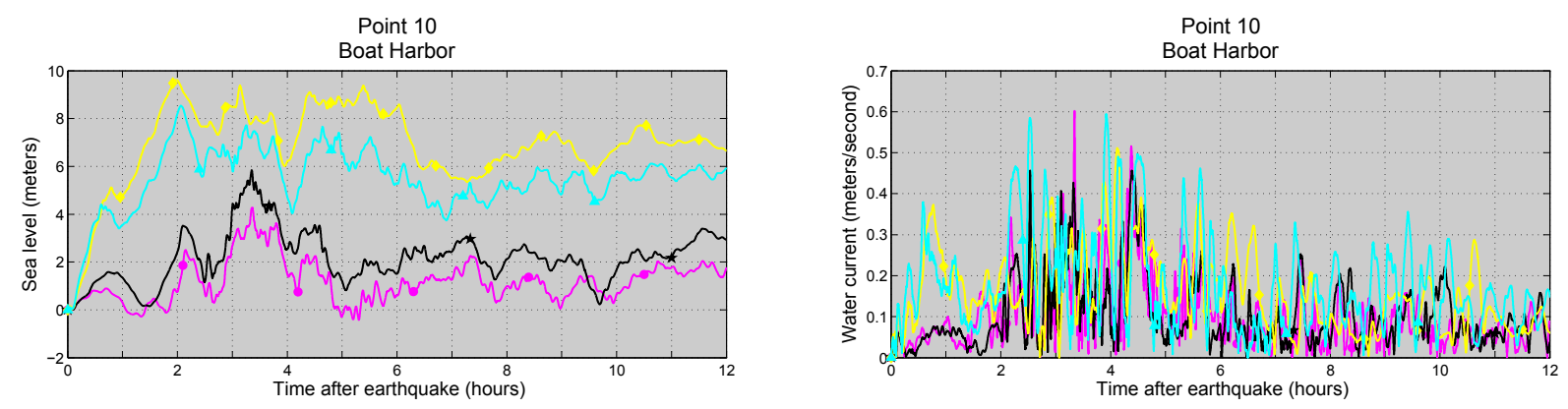

Depth $9.8 \mathrm{~m}(32.3 \mathrm{ft})$

$\rightarrow$ Scenario $4 \rightarrow$ Scenario $5 \multimap$ Scenario $6 \nrightarrow$ Scenario 7

Figure B4, continued. Time series of water level (left column) and velocity (right column) for tectonic scenarios 4-7 at selected locations shown in figure B1. Elevations of onshore locations and ocean depth at offshore locations are given based on the pre-earthquake MHHW datum. 


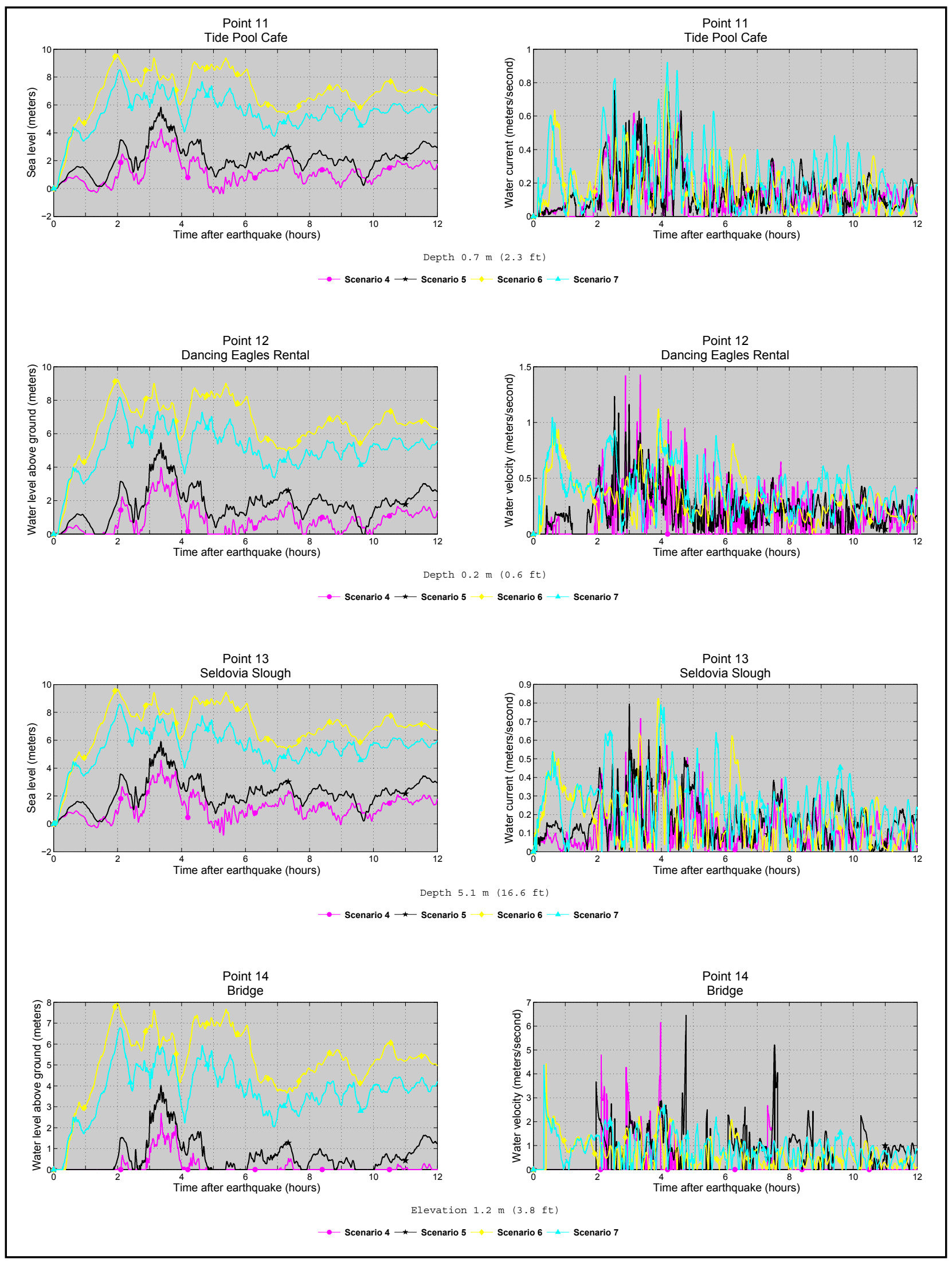

Figure B4, continued. Time series of water level (left column) and velocity (right column) for tectonic scenarios 4-7 at selected locations shown in figure B1. Elevations of onshore locations and ocean depth at offshore locations are given based on the pre-earthquake MHHW datum. 


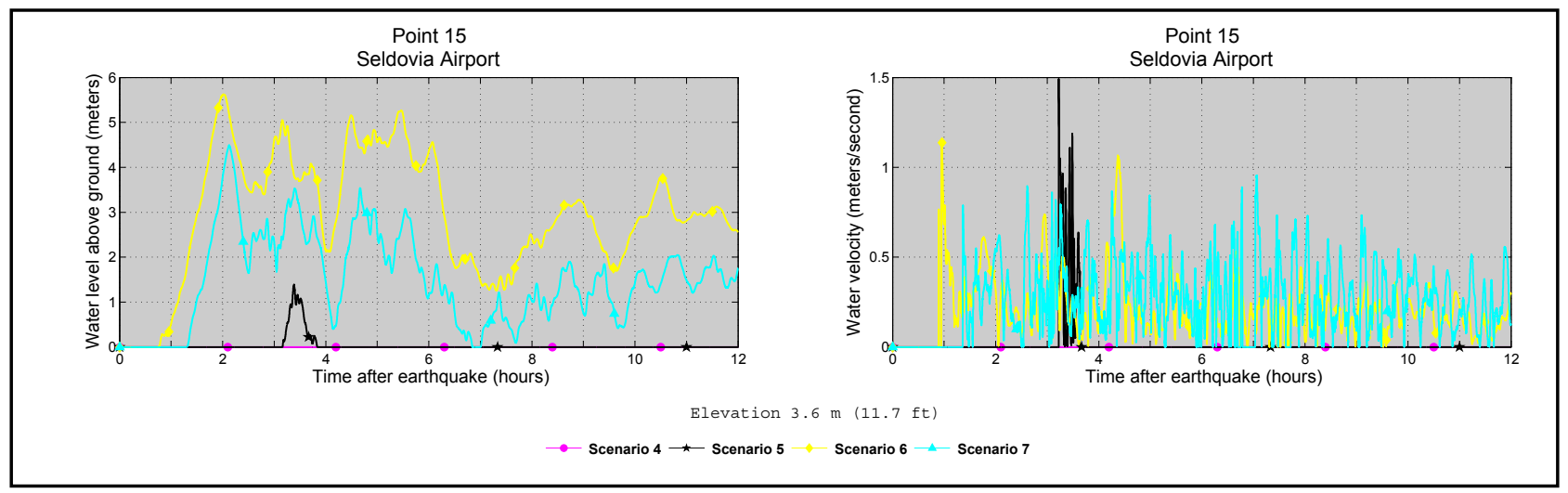

Figure B4, continued. Time series of water level (left column) and velocity (right column) for tectonic scenarios 4-7 at selected locations shown in figure B1. Elevations of onshore locations and ocean depth at offshore locations are given based on the pre-earthquake MHHW datum. 


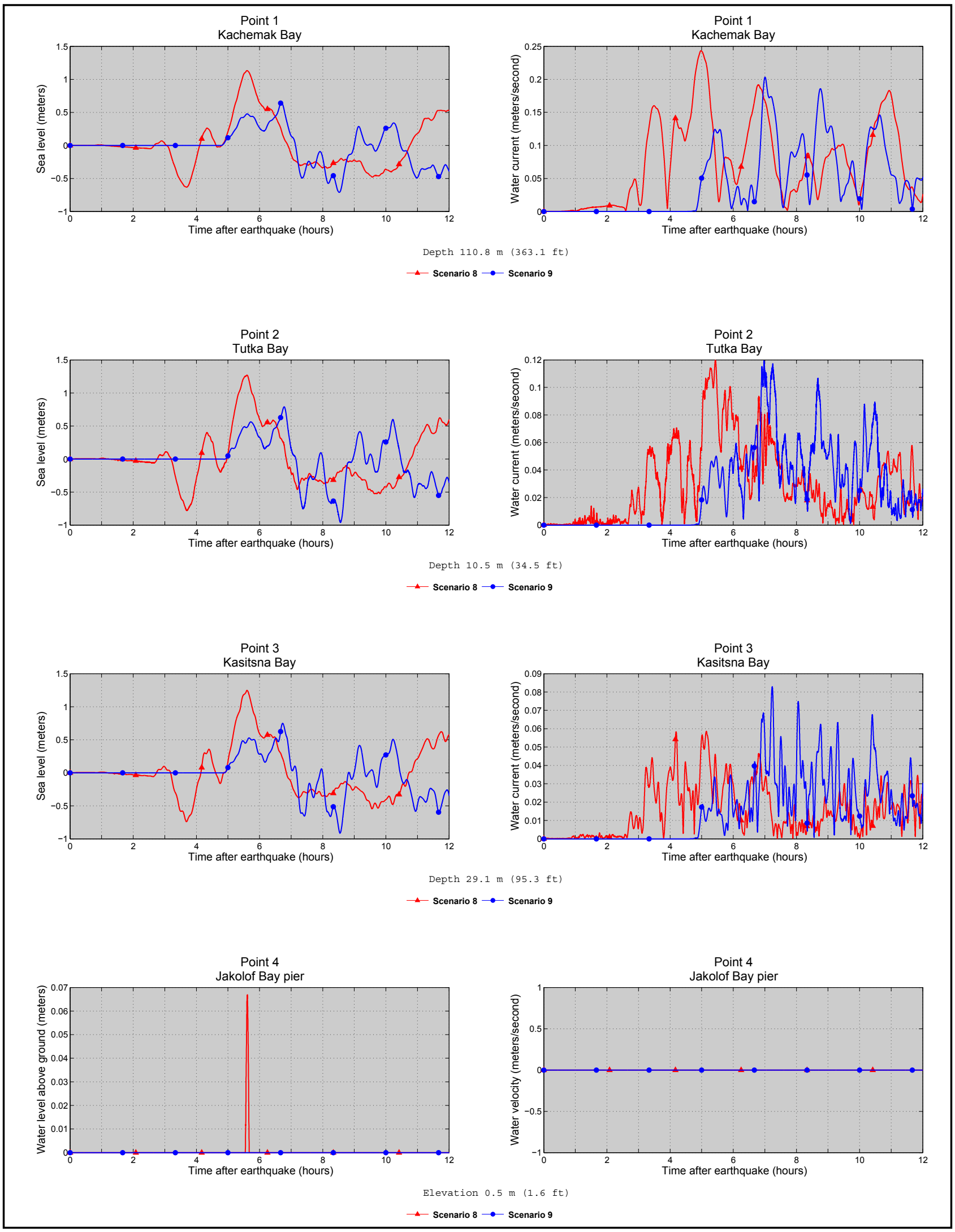

Figure B5. Time series of water level (left column) and velocity (right column) for tectonic scenarios 8 and 9 at selected locations shown in figure B1. Elevations of onshore locations and ocean depth at offshore locations are given based on the pre-earthquake MHHW datum. 

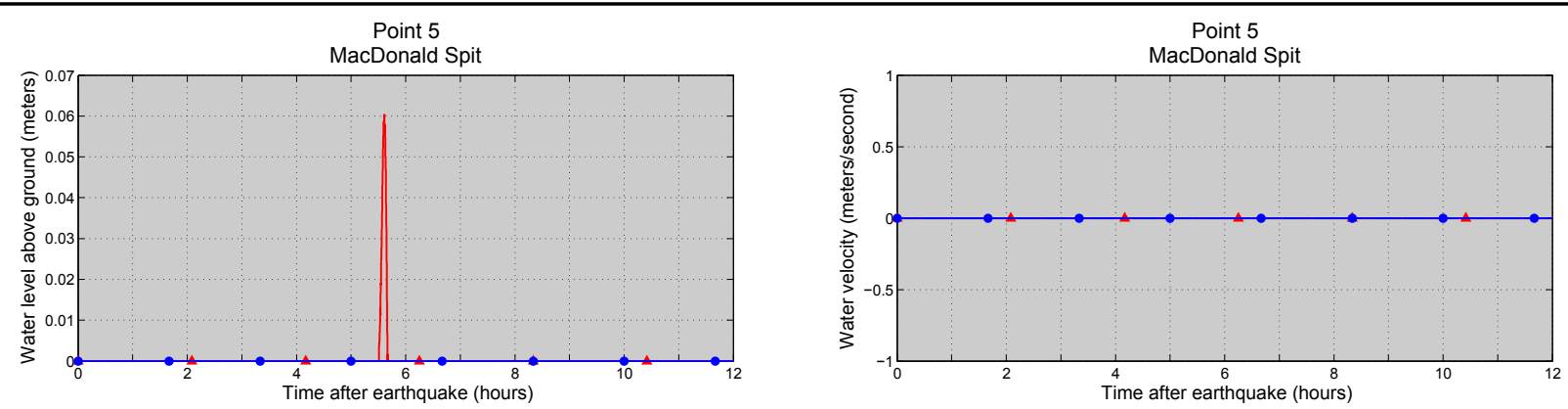

Elevation $0.5 \mathrm{~m}(1.6 \mathrm{ft})$

$\triangle$ Scenario $8 \longrightarrow$ Scenario 9
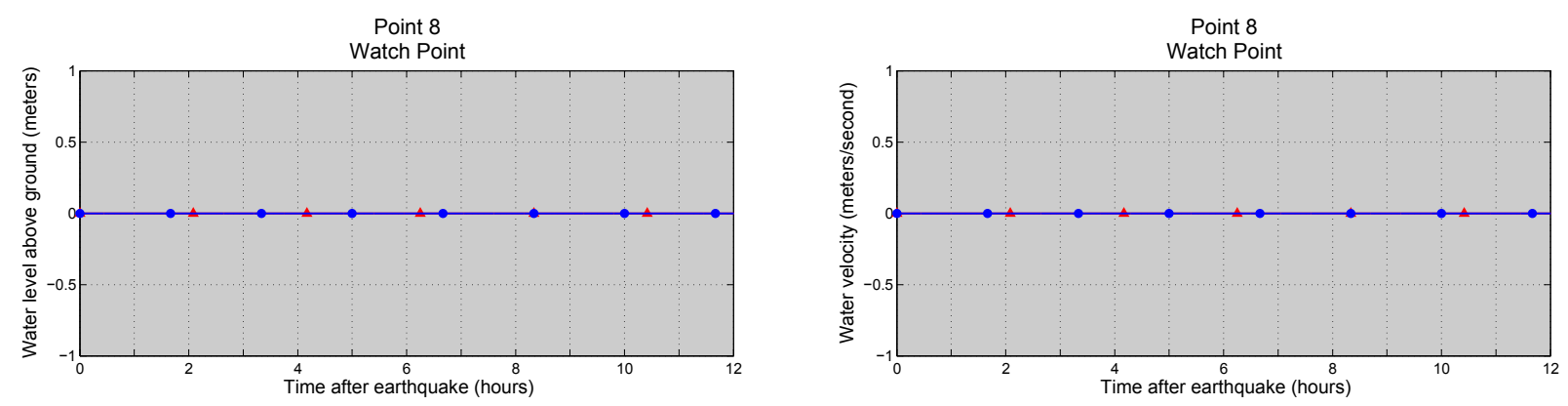

Elevation $0.7 \mathrm{~m}(2.2 \mathrm{ft})$

$\longrightarrow$ Scenario $8 \rightarrow$ Scenario 9
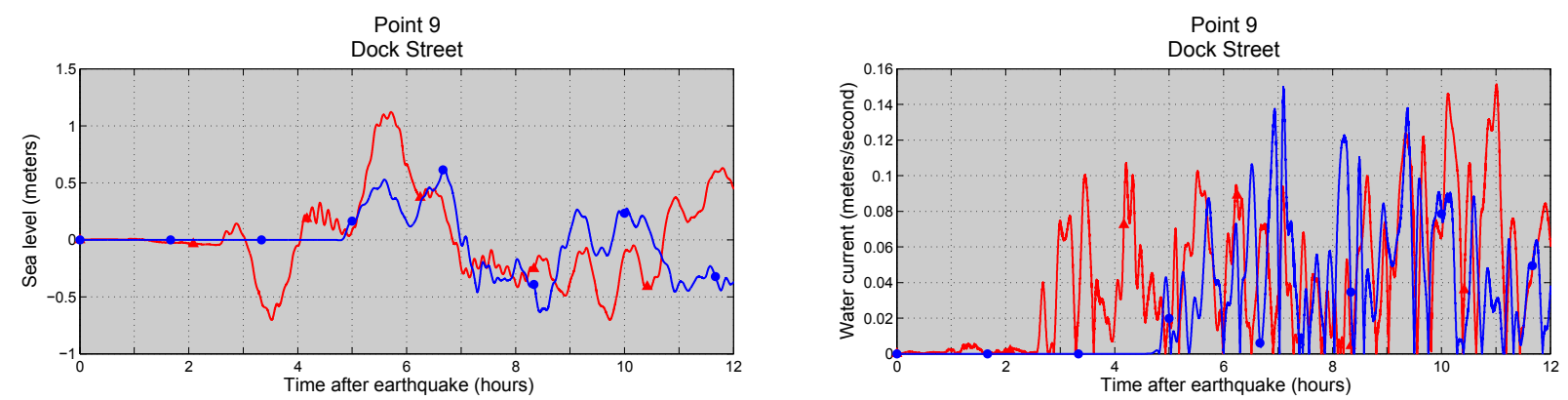

Depth $7.4 \mathrm{~m}(24.3 \mathrm{ft})$

$\longrightarrow$ Scenario $8 \rightarrow$ Scenario 9
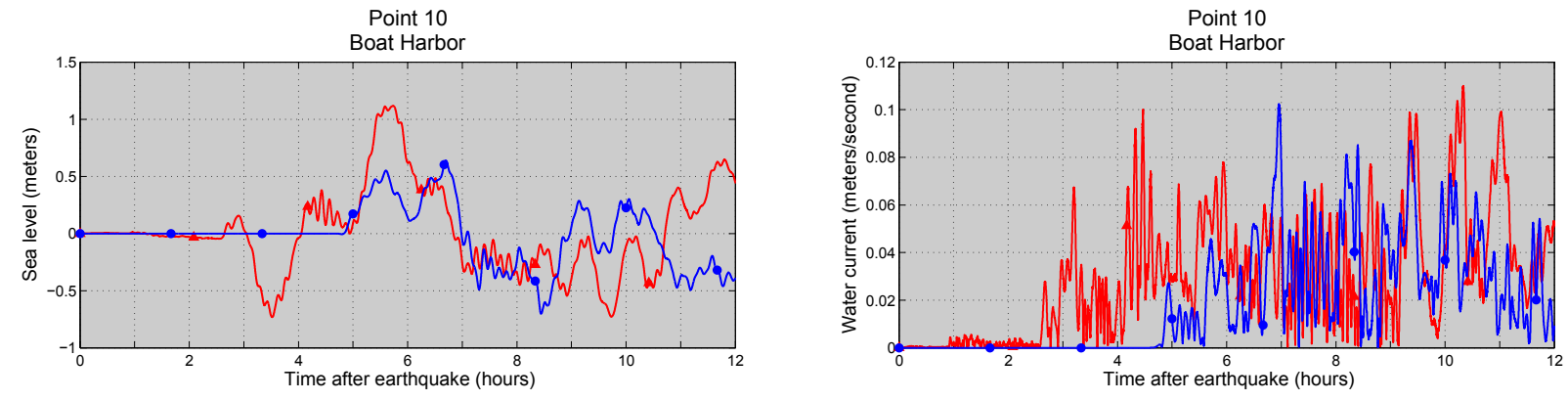

Depth $9.8 \mathrm{~m}(32.3 \mathrm{ft})$

$\_$Scenario $8 \rightarrow$ Scenario 9

Figure B5, continued. Time series of water level (left column) and velocity (right column) for tectonic scenarios 8 and 9 at selected locations shown in figure B1. Elevations of onshore locations and ocean depth at offshore locations are given based on the pre-earthquake MHHW datum. 


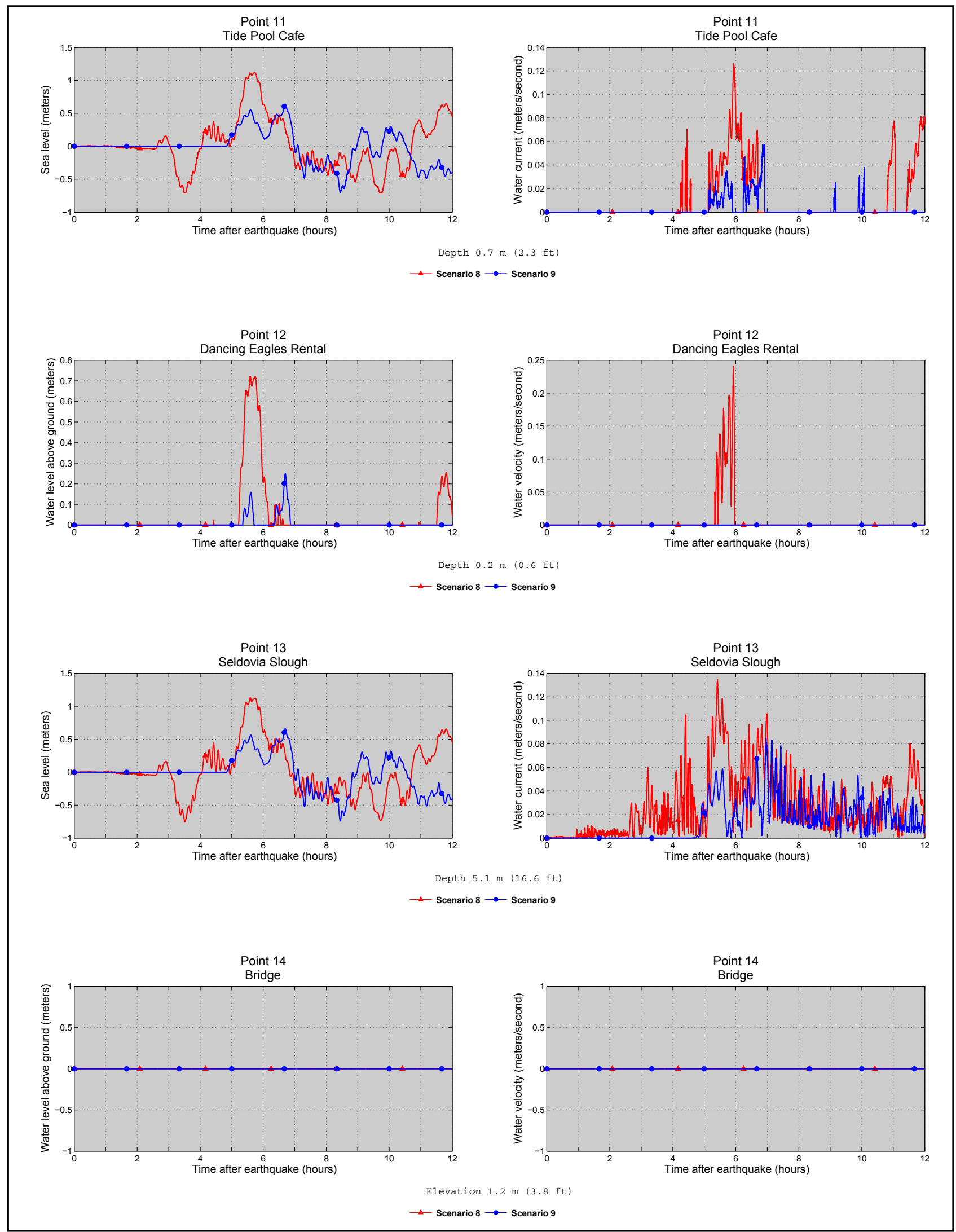

Figure B5, continued. Time series of water level (left column) and velocity (right column) for tectonic scenarios 8 and 9 at selected locations shown in figure B1. Elevations of onshore locations and ocean depth at offshore locations are given based on the pre-earthquake MHHW datum. 


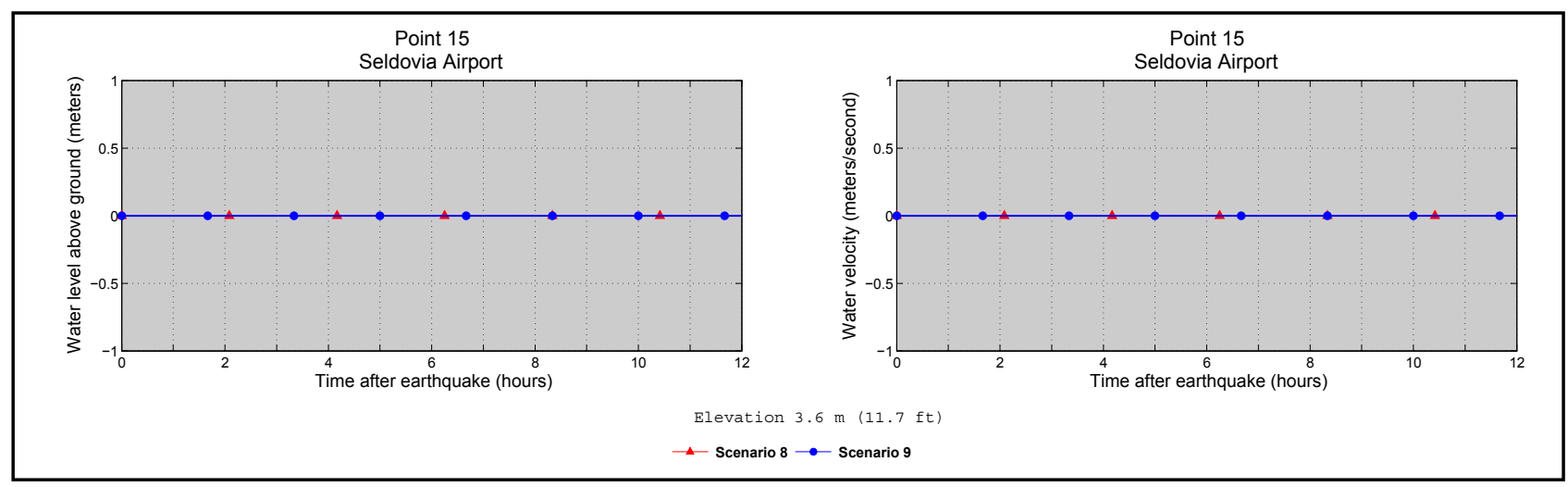

Figure B5, continued. Time series of water level (left column) and velocity (right column) for tectonic scenarios 8 and 9 at selected locations shown in figure B1. Elevations of onshore locations and ocean depth at offshore locations are given based on the pre-earthquake MHHW datum.

\section{APPENDIX C}

\section{Tsunami hazard assessment for other areas in Kachemak Bay}

Seldovia Village is a small community of 180 people on the south shore of Kachemak Bay, northeast of the City of Seldovia (fig. 2). Jakolof Bay is a recreational area with a few cabins, located about $10 \mathrm{~km}(6.5 \mathrm{mi})$ northeast of Seldovia (fig. 2). Map sheets 8 and 9 show the maximum composite calculated extent of inundation and the maximum composite flow depths over dry land in Seldovia Village. Seldovia Village is protected from tsunamis because of its higher elevations.

Map sheets 10 and 11 show the maximum composite calculated extent of inundation and the maximum composite flow depths over dry land in Kasitsna Bay and Jakolof Bay, respectively. There is a danger to people and property in these areas, including the piers in Kasitsna Bay and Jakolof Bay that could be destroyed by waves and currents.

Kachemak Selo is a village in upper Kachemak Bay, about $48 \mathrm{~km}$ (30 mi) east of Homer (fig. 2). This is a community of Russian Old Believers with about 160 residents. The highest-resolution grid that covers this community is the level 3 grid, with grid size of about $41 \times 82 \mathrm{~m}$ (table 2). The spatial resolution of this grid satisfies NOAA's minimum recommended requirements for estimation of the tsunami hazard zone (NTHMP, 2010). However, this grid spacing is not adequate for high-resolution modeling of the inundation zone, and no DEM verification efforts were conducted to reduce uncertainties in the fine-resolution grid that covers Kachemak Selo. Therefore, we provide only an estimation of the tsunami hazard zone. To estimate the extent of the tsunami hazard zone in Kachemak Selo, we run the scenario that resulted in the worst-case tsunami inundation in Homer and calculate the extent of inundation in Kachemak Selo according to this scenario. The results are shown in figure $\mathrm{C} 1$. The lower-elevation part of the community is within the inundation zone. Figure $\mathrm{C} 2$ shows the time series of the modeled water level at a near-shore location at the community indicated by a white triangle in figure C1. Zero time corresponds to the time when the earthquake occurs, and the vertical scale has a zero mark corresponding to the post-earthquake sea level. This accounts for local land subsidence in the community, which is expected to be about 6.5 $\mathrm{m}(21.3 \mathrm{ft})$. 


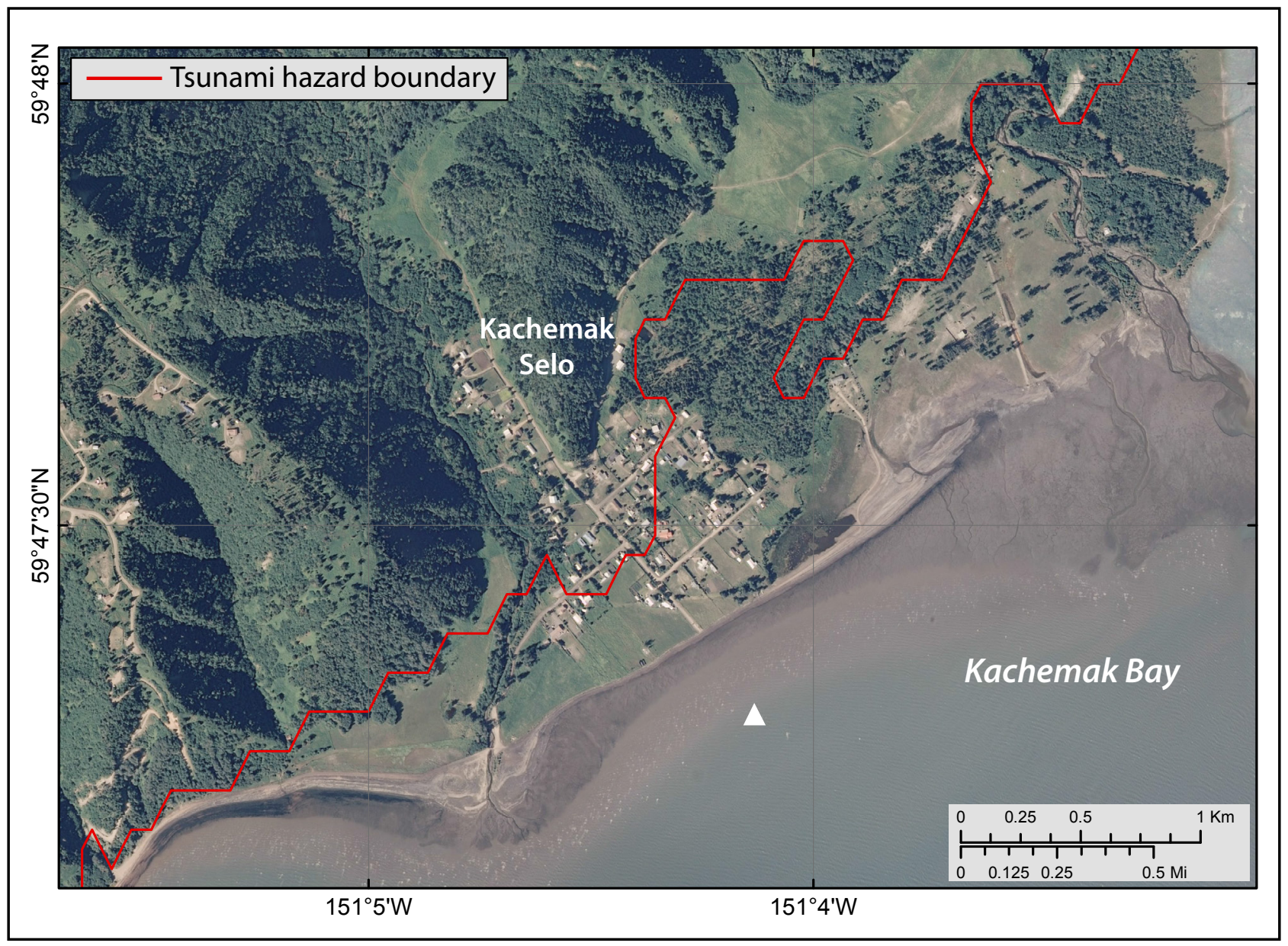

Figure C1. Tsunami hazard boundary in Kachemak Selo.

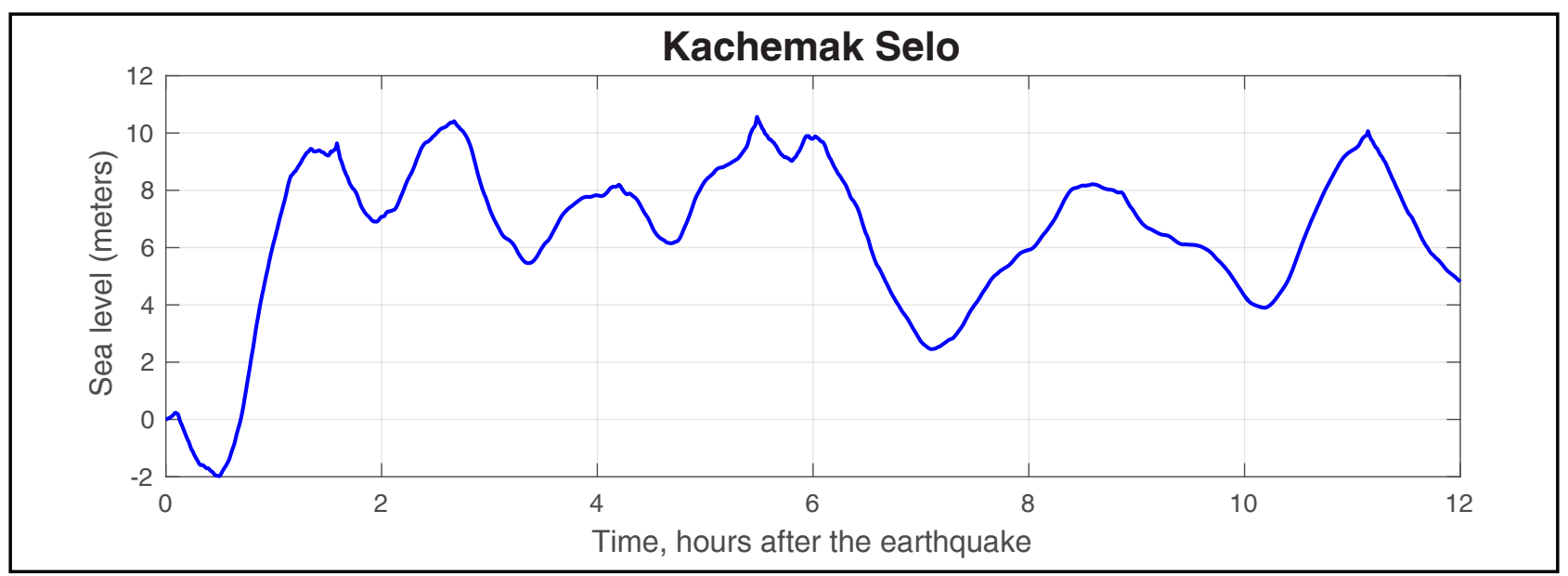

Figure C2. Time series of water level for the worst-case tectonic scenario at the location shown by the white triangle in figure $\mathrm{C} 1$. 